H53 



\section{THE NASAL ORGAN IN AMPHIBIA}

BY

GEORGE MARSH HIGGINS

B. S. Knox College, 1914

A. M. University of Illinois, 1916

THESIS

Submitted in Partial Fulfillment of the Requirements for the

Degree of

DOCTOR OF PHILOSOPHY

IN ZOOLOGY

IN

THE GRADUATE SCHCOL

OF THE

UNIVERSITY OF ILLINOIS 
Digitized by the Internet Archive in 2013 


\section{UNIVERSITY OF ILLINOIS}

THE GRADUATE SCHOOL

$$
\text { heay } 15^{\text {th }} 1919
$$

I HEREBY RECOMMEND THAT THE THESIS PREPARED UNDER MY SUPERVision BY Grorge thureh tiggins ENTITLED The Inaeal Oryan in muphitia

BE ACCEPTED AS FULFILLING THIS PART OF THE REQUIREMENTS FOR

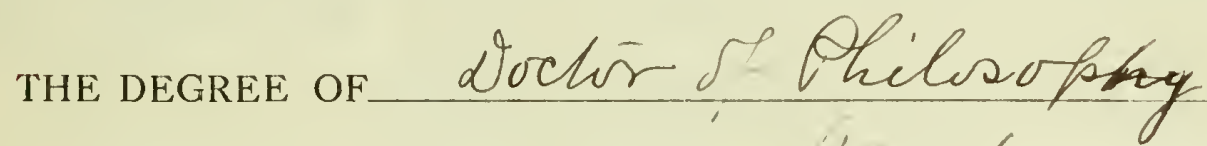

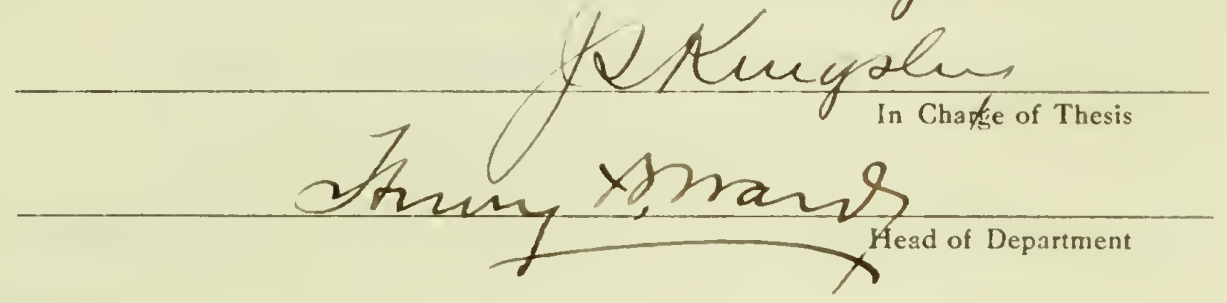

Recommendation concurred in*

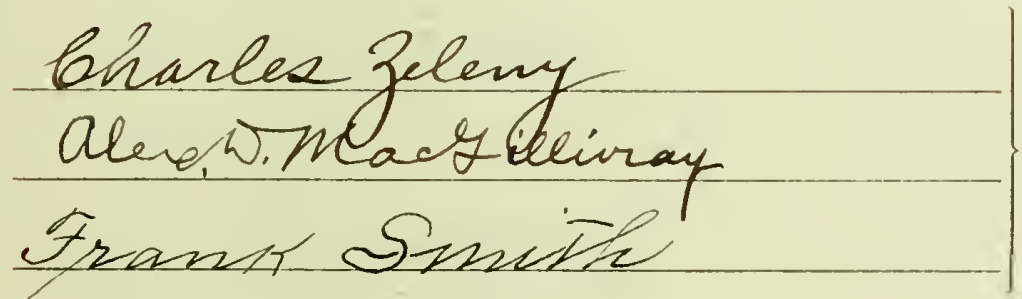

Committee

on

Final Examination* 

Rable o: งoñteñi.

I. Inusocircoion

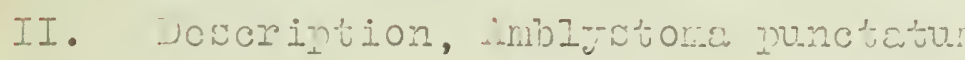

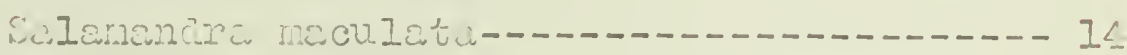

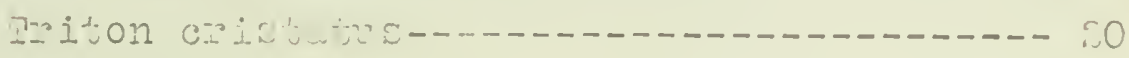

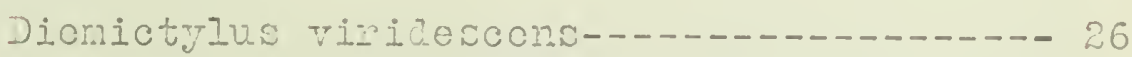

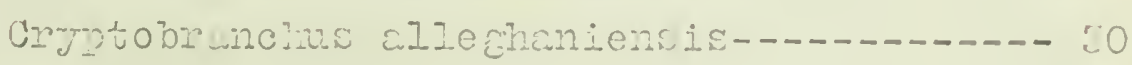

ijelcrpes bilinocitus-

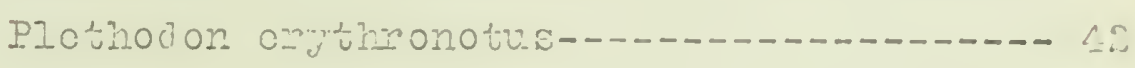

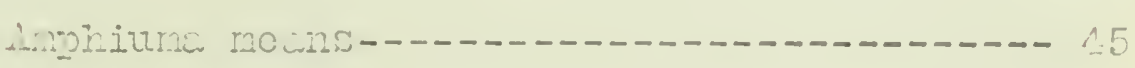

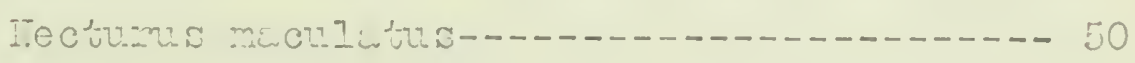

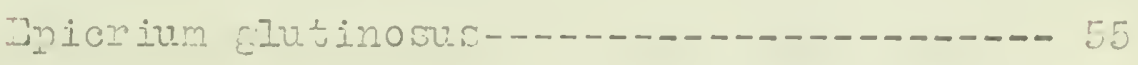

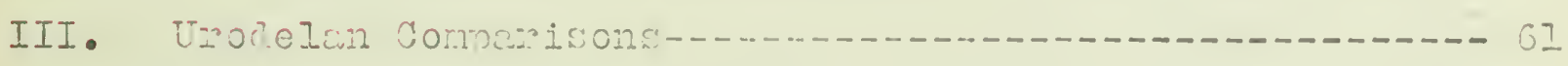

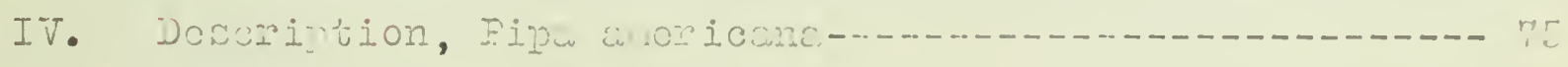

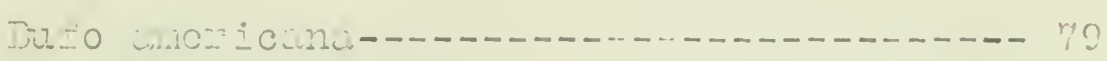

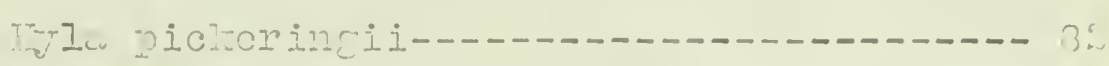

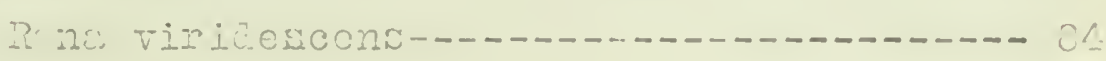

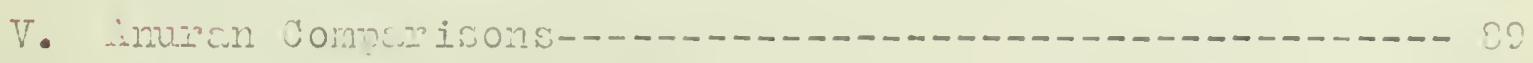

TI. DiscUssion--n-

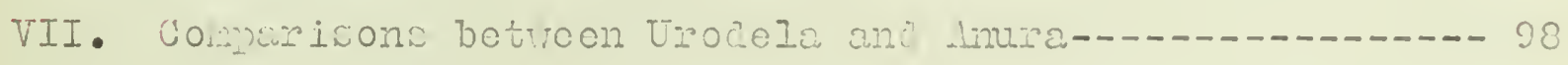

VIII. JIELEificution-

II. Amphijion incestigy-n-

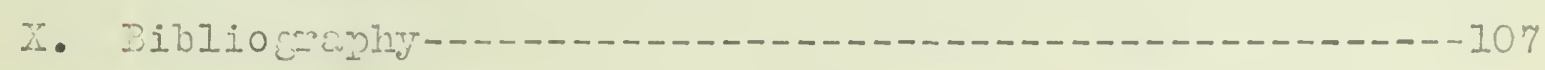

II. inbreviations [isod-n.

XI. Ixplinetion of DIates-.

zIII. IIZtos- 



\section{Introcuction.}

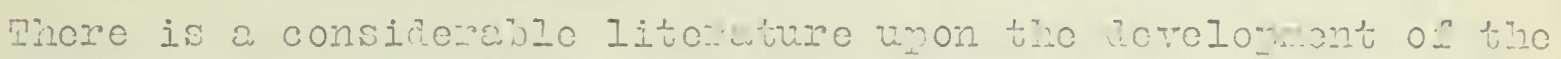

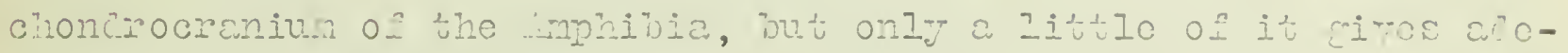

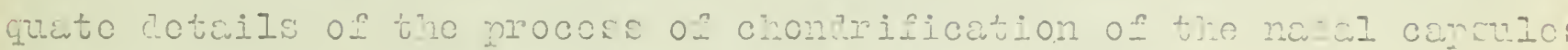
in this clisin of vertebuzuco

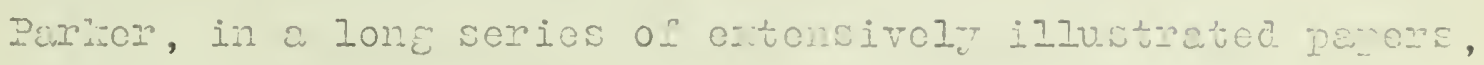

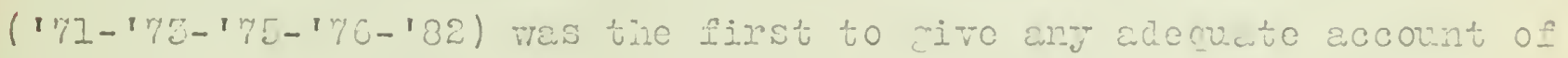

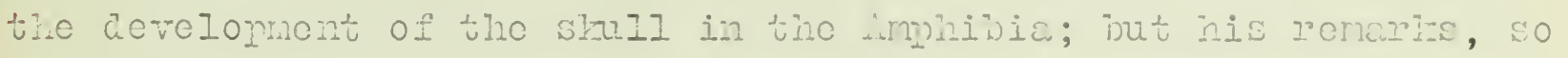
far as tho nasil capsules are concomed, wie conolici and ro letuilod cescriptions of parte or procasses of chondrifichtion ane uiven.

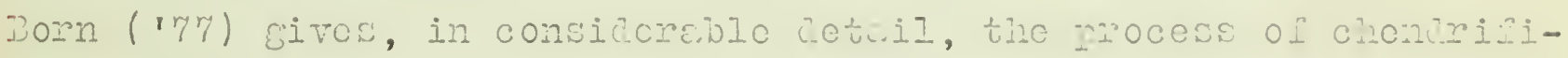

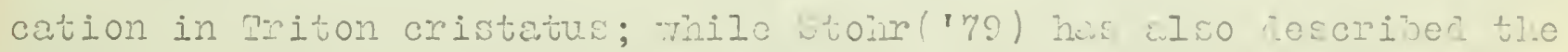

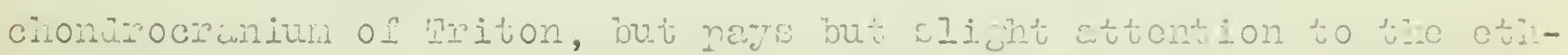
noicial resion.

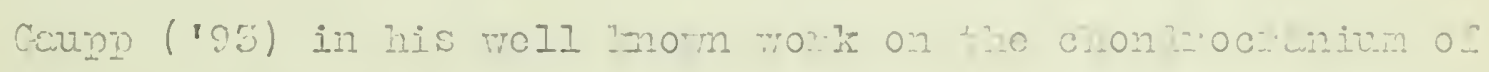

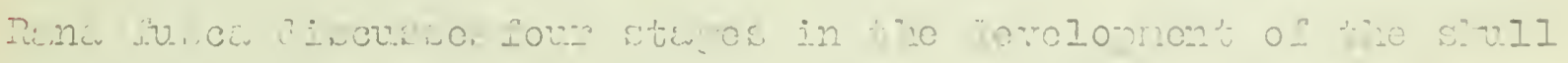

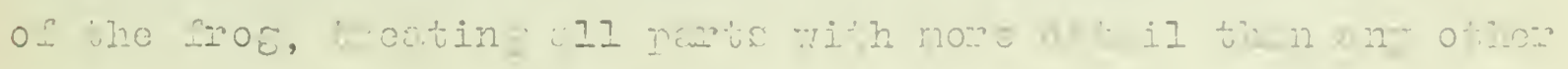

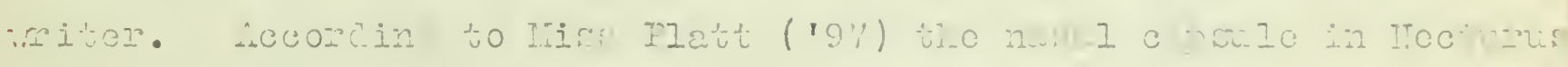

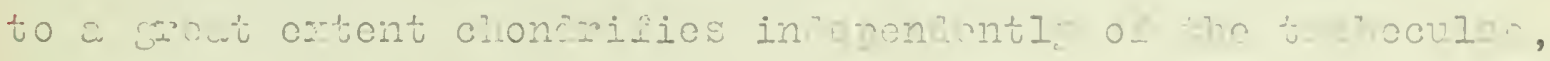

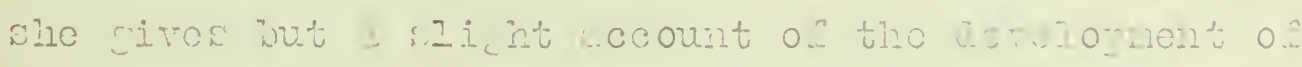

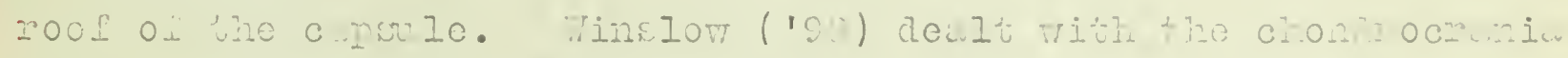

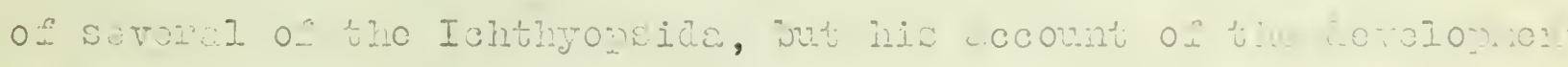

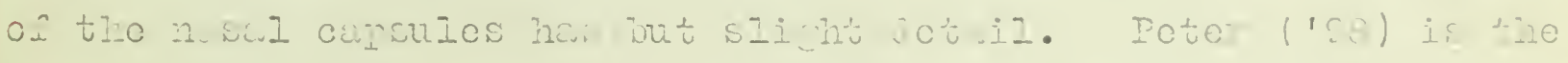

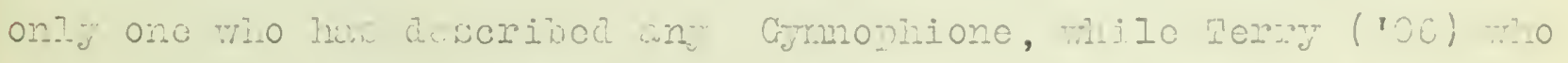

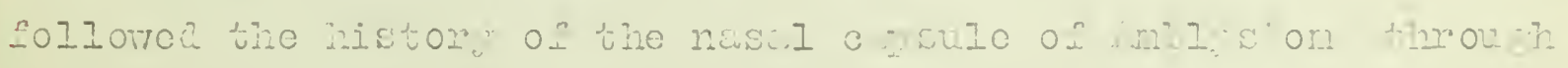

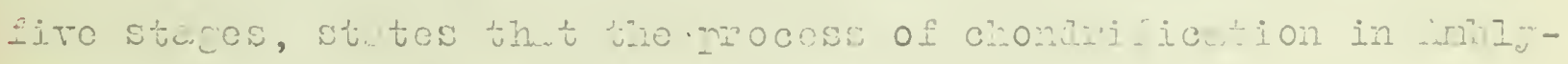

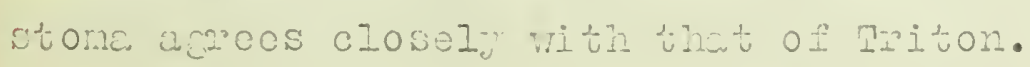

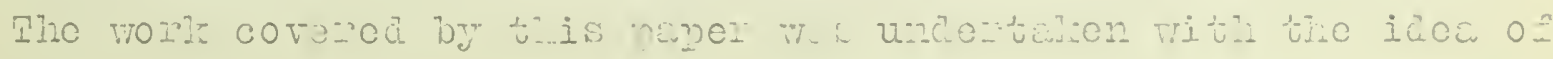





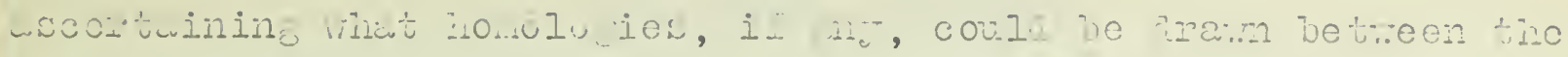

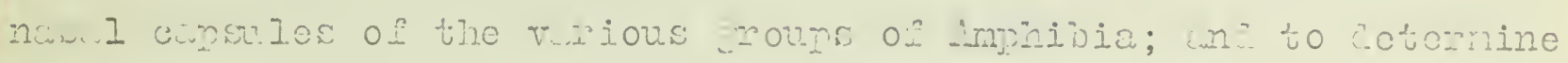

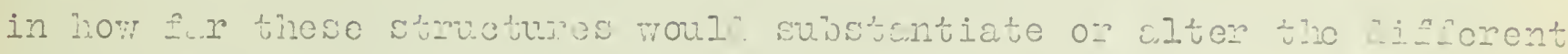

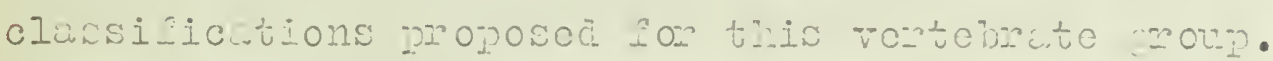

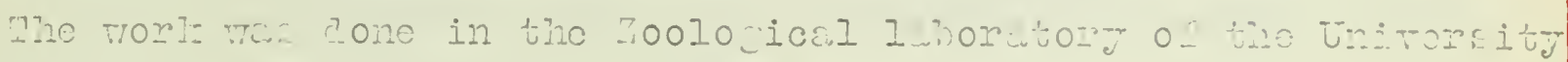

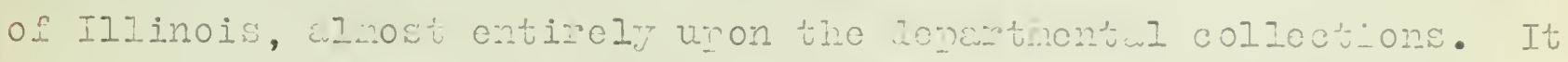

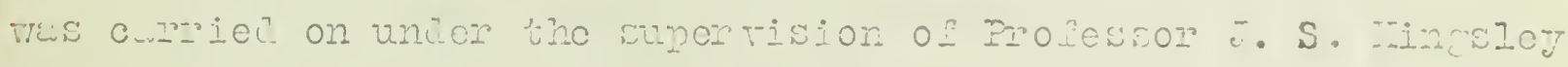

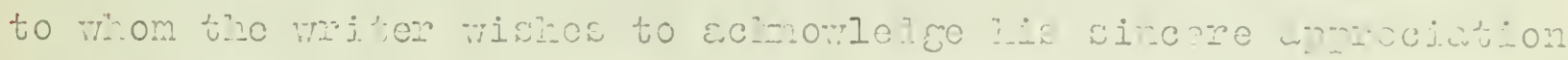

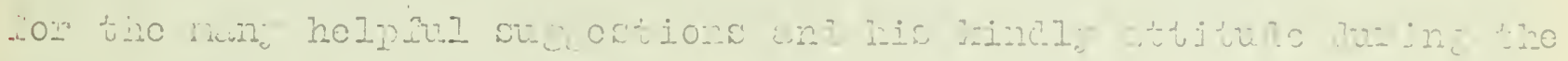

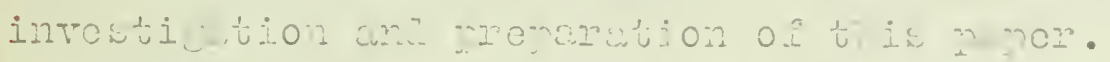

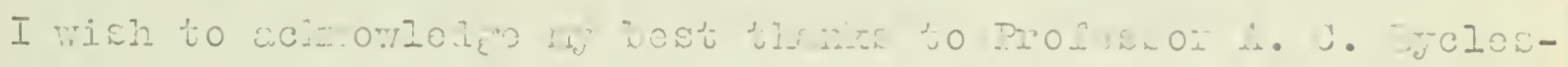

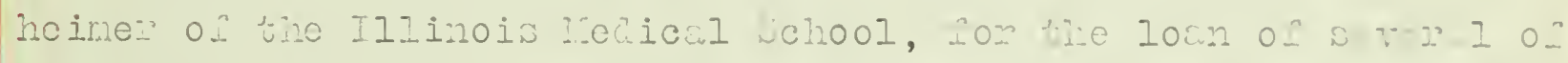

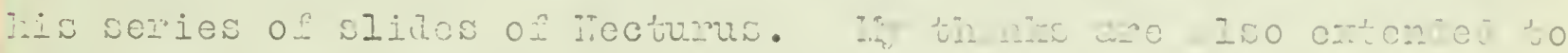

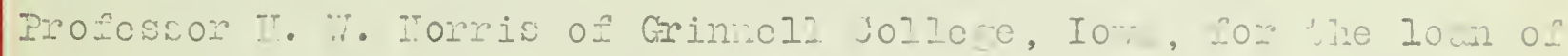

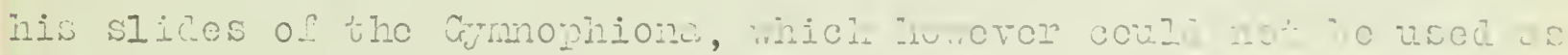

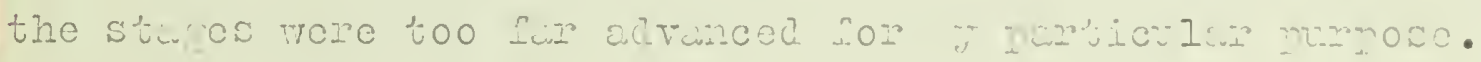





\section{mblystom: annctatum.}

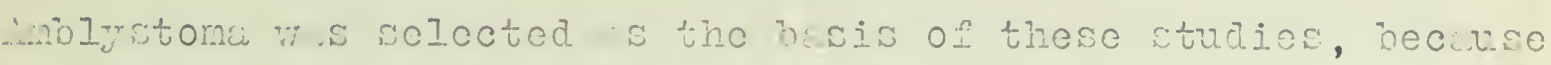
of the lorgor number of stufos avil ne nd becunc of its intermedite position mone the Urodelos. I lwre studiod ni moúlied soven wtwes of hablytoma mhich whow the wucessite ators in the chondifiction of the nis.. c nsule.

-. Inrva II mm. Iong, (fie. I), shors but fow fo turea of a nisal cupsule. In the region of the oye tho troboculce (t), with slighty dovelopod crist.e, inclined to nd o.ch otnor, tus io not meet to form in cthmoid plute. Mhoy re trimeula in icction sno Iic alone the mesul misin of the nusul E c. intoriorly cach

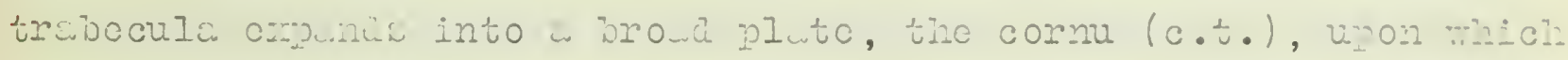

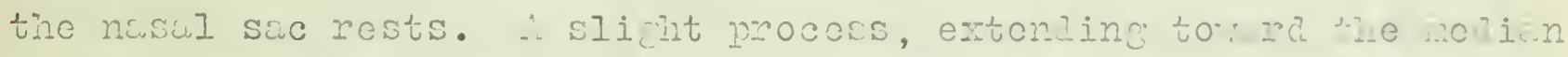
Iine from ewch trabecula is to form the cthmoid olu.to.

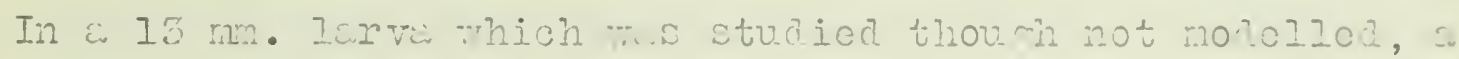
fow c rtilivo colls annein wbove the mesul normin of the cornu trubeculac of the loft wide only, rery ner the chterior ont.

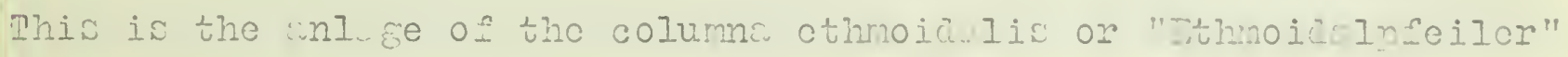
of Cunp ('OE). In this wtace noither trobeculur crosts nor ethroid pliuto hito becn formod. (

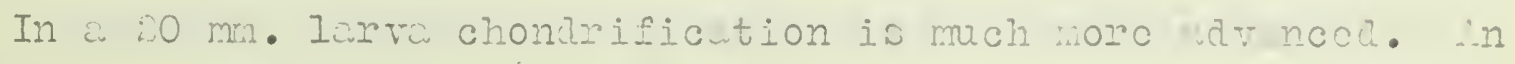
cutorbital procoss ( extoncis I tor...IIy a distince cnul to the width of the trifocula, which has hecome circular in section wa tho two trancculie heve united in the medion Iine to form a road planum cthmoidalis (v.c.), suporting the whterior cnd of the tolencophilon. The Iateral n. rgins of the concuve ethmoid nI to wre mplued by thickenin s,

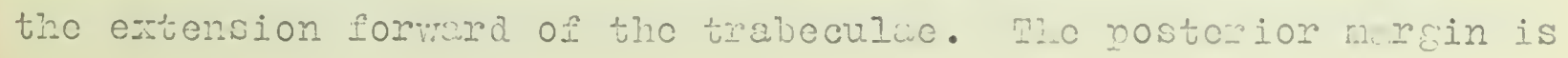



arcuate, the entowior moro ne rly streicht, passinc into the oupunding comua, which have incrowsod in sizo nd form tridncular plates in precticrlly the samo plano sis the trabocula. The dorsal surfece of e..ch cornu is wightly conc. ve nd suprorts the nasal sac and the organ wh I nds of Jacoinon. The postorior end of each cornu roachos about tho level of the midale of the othmoid. plate, where it terminites in a sight cural mocoss; mile its antero-lateral maroin is at wbout an male of 45 emees to the medion aris of the chull nd neets the inner marein of the cormu, extendine forme from tho nterior mircin of the ethmoid plate, it cin acuto nie.

Doracl and purallol to tho trabecular ortonsion (t.e.) of either sido is un olongute rou of e rtil. No, tho columin othmoiznlis (c.e.), the unluge of which hes specured in the $15 \mathrm{~mm}$. I rra. It Iies betwcen the telencopharon ind the nasi. swe nil extonds itust posteriorly beyond the cudul linit of the etrmoid nIate. In a similar stage Temry (106) hws coscribed the junction of tro caural ond of this rod with the trubecula, but I he ve not soen this condition in my moterial. It is not connected with the tribecula but onds in

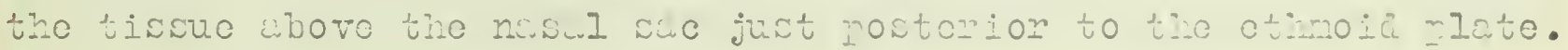
from the c vdul limit of the bur, chondrifiction is dorelopinc loterally, to form the anloge of the lomin cribosa. It is of ospocis intorest th t this cod, though litor fusine ath the trebecula crises inderendently of it. It is of furtho interest thet cuthough chondrifiection of this rod derelons nostoriorly from its

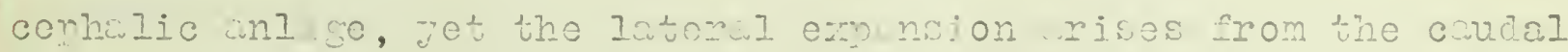
Iimit.

In tho next st ce (fic. 3.), sovor I featurea huve been adod 

to the capsule, The cristre trabeculorum (er.t.) ure well beroloned wh their cephalic margins hate united to the columne ethmoidalis, thus jormine w wide trough in mich the telencenhalon lics. The cristie traiceviomm are curved unon their inner wasect und ortend former to the rogion of the chome, from mich tho trabecuIur extensions (t.e.) turn cibrunty tortore the center to form the etrmoid late $(n \cdot e \cdot)$. In this stage trere is an clmost comilete Serwrtion of the dorss I from the ventral half of the cisule, the crista trubecula forming the only connection. The nedicn processes of the othmoidel colums hro vnitod to form the herin inc of a nuwl sopturn just dorsil to the cophale Iimit of the ethmoid nlwe. $\therefore$ Ithough chondrifiction is in procoss, is shom bu the wrosence of procurtilige cells, the septur is not complote nd rere is as yet no union of the colum e ethroidalis nd the ethmoid nlste.

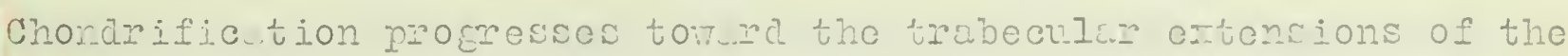
etmoid plute, and not in the opnosite direction. The dorsul

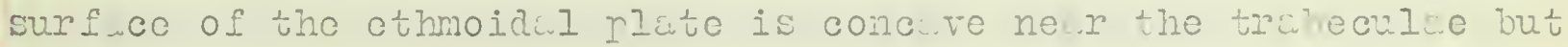
become olishty contex upon its cerhile merin which con imes letorally into the browd cormua. These cornus ere ror chly triangulur in ovtline und ure Elighty concuve dorsaly to sunnor the whtorior portion of the nass or wan. The lateral murin is bro dir conver, enbraing an re of chout 90 decrees, as it currtes latere lly wh ventrally from the om rginate limits of the ctimoid plite to point in line with its nedian lane. It teminites posteriorly in a short process unon which tho cophlic portion of the oren of Jicobson rests.

Botwecn the cornu tribeculi und he unorbitul pocess is a wide buy in which the min nesal sac wa the nasal Iunds lie. 

The ethmoidel colvmne remin parallel wa dorsul to the trabocular extensions, ilthovgh sererw modific tions occur. Fach column detolops a letoral expinsion, the bocinning of a nasil roof. This is especially mrled posteriorly whero, ius chorion to its junction aith the crista, w curved plate passes laterully over the caudal linit of the naskl swe and the chowa. This is the furthor devolonmont of the lanin cribow (I.c.) described in the exrlion strge. Ihuther enteriorly this nod is considonculy fluttened and

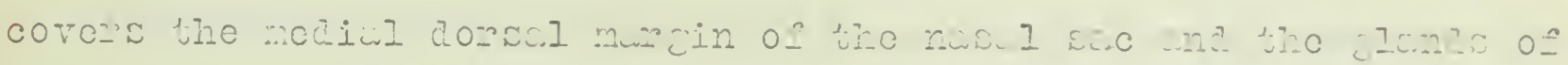

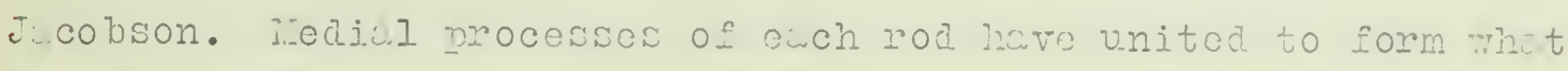

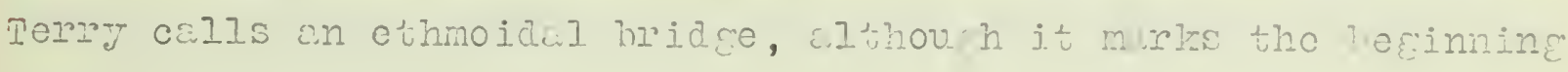
of the nisil sontun, comleted in the lator stimo. The fonestru

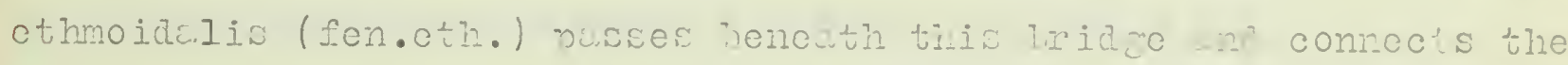

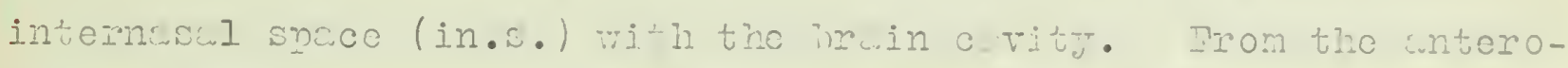

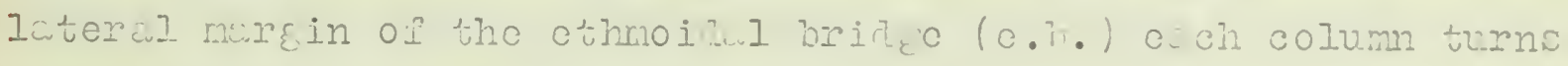

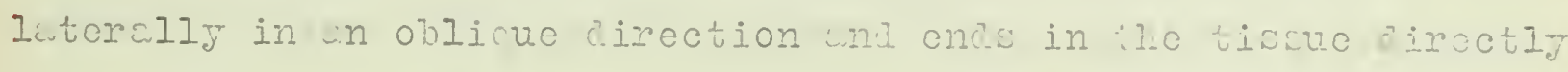

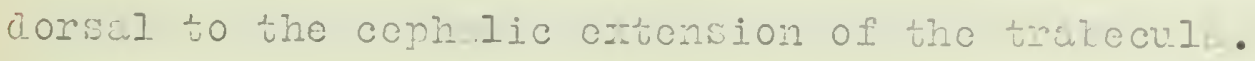

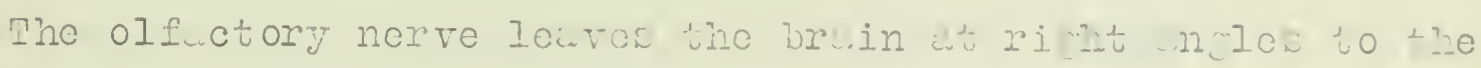

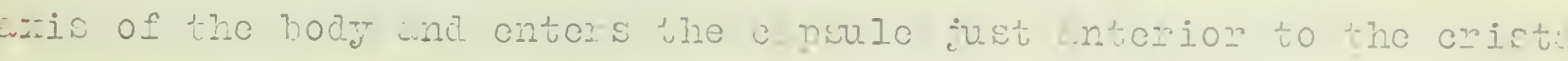

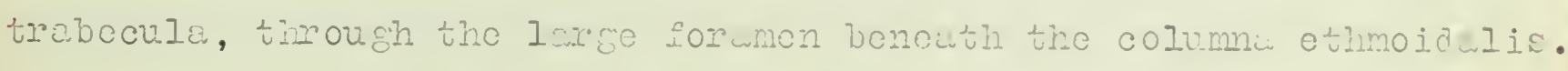
Ít dirides into dorsul ind rentriz roots.

In a lirve 54 mm. Iong (fie. 5.), the colvma cthmoidilia hes fused rish the trabecula, sopirtiod from it only by the smil olfuctory formon $(f .0$.$) , to be described liter. interiorly the$ ethmoidal colume hive united to the trobeuler extensions, thile postoriorly they he ve unted to the corsul crodis of tis trabeculie; so thet colum ina crista of eithor side appor tis ono continuous clevetion, picrecd by üc olfwctory formin. Junt cnterior to 

theserormine the ethnoid plute, which is thin behind, Decomes abrupty thiclened, the result of the furion of the ethmoidal bridgo With the othmojo plate of the preceding stuce. The fusion of tiese perts and the wusecuont caudal growth has produced the brosd and thicl soptum of this stace so charactoriatic for the imblyatona capsule. By recison of the antero-latoral expensions of the sortum, ita anterior murgin becones deenly czecrute, forming a V-shaned internasc s spice (in.s.). Wcch l toral surfuce of the sentum n si is curved and bordered dors Ily by the nedion nasul mocess which corers the medicl and dorsal surface of the olfactory organ. Ilis procoss continues anteriorly, and, near its cephalic marcin, is pierced by a foramen (f.n.i.) trrough which the rams nas lis intornus of the fifth nerve passes to the internascl wpwee.

The expanded cornuc trabecula continue from the antoro-lateral m.reins of the othmoid plate. They do not differ Erewtr from the precoines stwe. The lateral marcin of each cornu is brosdir conver and cxtonis cuncully to the lovel of the powterior linit of the sentum nasi. Prom its junction to the lateral mergin, the nosterior markin is directed modiclly for a short distance whon it furns abruptly cophalca and then, with co brodà sweopinê curto, continues posteriorly and fuses rith tho caudal lateral marmin of the etimoid Dlate ventral to the olfwetory foramen. Detreen the curdel outension of the cornu and the cephelic rortion of the lamina, Jot to be described, lies the orman of Jacobson, and the clinds of acobson extend mediclly from this process.

Just dorsel to the olfactory forcmen a strong lamina cribosa (I.c.) extonds laterally and anteriorly and, curvine ventrelly forms a valt ovor the caudal limit of the nasal sac. 

Its lateral margin cxtends necrly to the letel of the gan between the caudul extension of the cornv and the antorbital process; the posterior margin of the lamina is oblique, its lateral marein

slightly arcuate, and its anterior mergin continues forward as a small coniccil process to the level of the posterior markin of the cornu trabccula. The stagos thus for described, show thet the lamina cribosa is developod as a latoral outerowth from the caudal part of the columna ethmoidalis.

The intorbital process, outlined in the preceding stace, is now more strongly deteloped and more closcly wsocilited with the cunsule. In the ecrlier stace it wa considerably removed from the cthmoid plate, but by formard growth its anterior marcin is now in line with the posterior morgin of the ethmoia. Jach process extends laterally a short distance and then bencs wivetly forward and terminates anteriorly in s small projection posterior to the covdal lateral angle of the lamin cribost. The nroximity of the antorbital process to the lanina is indicutive of the purst its is to tale in the completely differentiated capsule.

In a $45 \mathrm{~mm}$. Iorva (fig. 7 ), chondrificction hs not Erectly advanced bezond that in the $34 \mathrm{~mm}$. Stage. The capsule his not incroased in length although thore is an appreciable increase in dopth and in breadth. The forobrain lies wishin the brain case (c.c.) for about one-third the length of the consule and, with growth and development of the olfwetory lobos, fhere is a corresponding increcse in the wize of the brain cwe thich is now aprrorimately hemiapherical. The olfcotory formina look oblicucly forwera and the olfactory norves pass obliovely from the anterior marfin of the olfuctory lobe to the ccudal region of the naski sac. 

The olfictory organ has moved form red so that it is anterior to the forobrain excopt for its ccudal one-third; a rolation which is more pronounced in tho last stuge to be described.

Tho nasal septum (s.n.) has cecreised slightly in length although it is almost trice as thick as thet described for the $34 \mathrm{~mm}$. stage. Its postorior dors I mergin is broadly concave, although the postorior surface is almost vorticel to the plane of the ethmoid plate, which curvos domverd and backwrd. The intornisal snace bounding the septum in front is arcuate and is occupica by the intermaxillary glands comon to most Urodelos. Tho modicul nasul procossos (m.n.p.) of the ethmoidil column hure doveloned latelolly, wo that thoy now form a roof for the mosil half of the nasil orean. Each is pierced nex its latoral margin by a formen for the branch of the nasalis internus which innortates the anterior dorsul recion of the snout. interiorly each procoss torminctes corunty and is soperated from the blunt trabecular oztension by a notch, the modion nasal incisure of morry ('O6), which allows for the pascige of the main rams nesalis internus to the internasul spaco. In the $34 \mathrm{~mm}$. stuge the notch and the foramen were now each other, but tiney he become separctoul in this stcuge by growth in the intormodiute recion. anteriorly procurtilage cells cover the cursule and lic uround the nasal duct where it passos inw ra to unite to tho min nosal swe. Those procartilage colls suggest the rult thut luter forms over the entire cephalic end of the nasul capsule.

The Iamina cribose (I.c.) is more vaulted wn covers the nisil organ from the choana to the roll developed orgen of dacobson which lies betweon its rontral marein and the cudal extension of the cornu trabecula. interiorly the distal anfle of the lamina cribosa 

has fused with the cornu trabeculc so that there is a comolete band of cartilage around the external naris. The neso-lecrimul duct passes above this connecting bar cna unites to the min nasul sac just chove the cephulic linit of ércobson's organ. The nas I canal formed by the ring of curtiliege is an elongtue ovoid, exposed on its dorsal curface by the broid bay, the fenestru nurin (fon.n.) of caupp,and, on its rentral surface, by the oril kan between the wntorbituil process and the cornu.

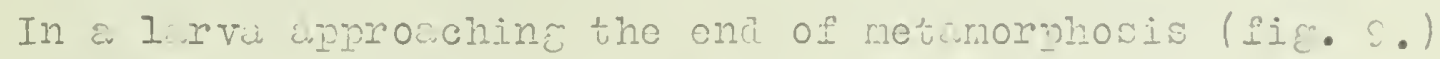
many modificutions of the nis. I c prule codi to the complexidy of the structure. The length and brewdin of the cinsule wre winrorsimutely the sure, wlthough there $h$ s been cojuction in the lendin of both septum ncisi and othnoid plate, so that the anterior threefourths of the nasil scic lies cephelad to the forebrin. The nawal septum is reduced in viath by one-inclf, to accomoicte the laterul growth of the olfuctory orguns of the wo siles, which nom more

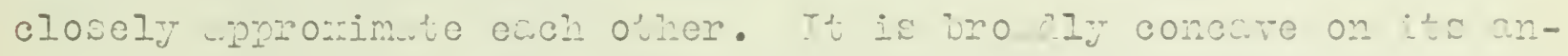
terior surfwce, the dorsal mersin extending more ceohl d thwn the ventral, so that a particul roof is formed over the inter-nisul spcoe.

The medion n S I process(m.n.1).) and the lomina crithose here expander lotercily and form a complete roof over the na su suc. nteriorly the cephalic port of the meriun nusul process cnd the cornu trabecula have uni'sed bove the distal end of the olfectory orgen to form a complete rult of c ritueg. This growin his necessivated a chinge in the position of the extern I nuil onening which is nom lwteral in contrast to the termin l position of the ewrlier stages. The browd deep buy of the renestre narin has 

been oblitorated wo thwt the narial opening id now an elonewte ov. I, looling obliquely formira.

The antorbital process hw united to the lwin cribose, condition suggested by tho close ssocition of these purts in the curlicr wtege, thus forming a cup-line structuro, piercod poster-

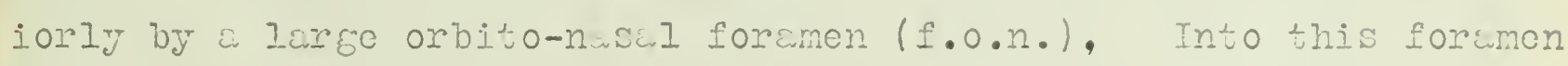
the caudal portions of the nid. I we he vertonded and throush it the nerves of the n sal region entor the capsulo. The united olements of the lamina cribosa and the antorbital process bond obli-

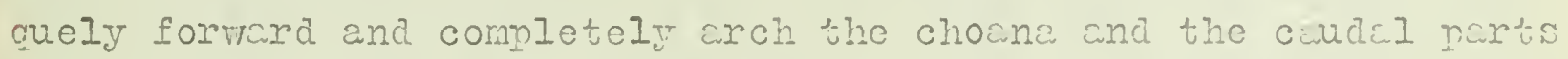

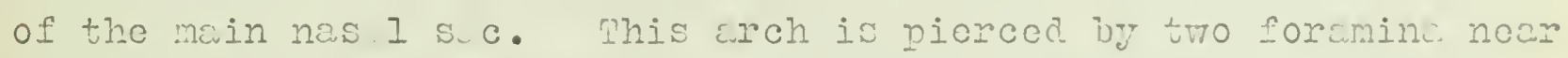
its ventrel leteral merein through which tho rerns profunius of the fifth nerve and tro blood vossels entor tho capsulo. Anterior to these openings, the cribosa unites to w mocess which I velieve to be the cudul oxtension of the cornu trabecula, minh a in curlion stacos so in this, onds blindy in w pocoss supporting the caudal pert of Jecoinon'a orgun.

In addition to the lure noriul oponine and wencreted from it by a bur of curtilage, the develonnent of the band of the ecrlier stage, is w wecond formen, the infra-conchilis of ciupp, (fen.i.c.) through which the or fun of Jacobon oxtonds to the leteri onveloping tissue. IJing close to this formen is a loor furmow in the Icteral surfece of the cribose alone which the n so-licrim I duet passos to its junction with tho nasel swe at the nostorior merein of the nisici openine.

The dorsal surfece of the roof of the chipule hos four foramina. Whe anterior threc of these cre smuller cnd conuct r mi of the superficialis of the opithanic from the concule. 

The posterior formen, directly opposite the ncs l sepun, is the larger and probubly reprosents the begimine of the resorntion of cartilase rhich so completely chenges the corsule to tho scult form. Tpon the moscl surfece of the curvule the formen nasulis internus conducts the min branch of the ruporficiclis to the in-

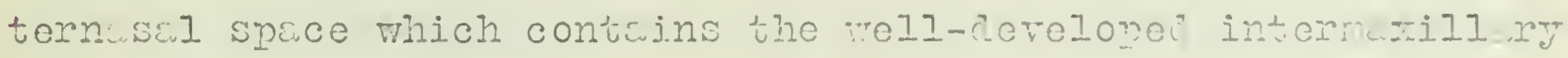
gland. A pronescul niocoss norize the cephlic extension of the capsule, and it extends formard from the mesir surfice newr tho dinove doscribed formon. Thero is lergo gin in the ploor of the cepsule, or l in outline, hounded by the ethrnoid nlate and lamina criboss on the sidos, onteriorly by the cormu trabceula, and posteriorly by the ontorbitul process.

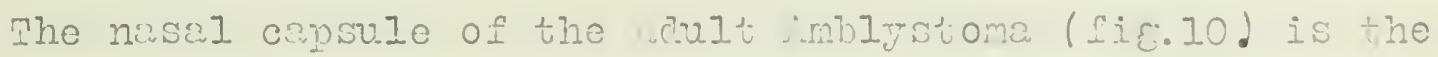
result of growth and sneciuliution of those stmeturos precent in the stage susu described. Tt in s incre sed both in width and in length by one-h If the orifin I dimensions; effected by wowth of cortain porsts unt a reduction of others. The sentum nosi wh the othuoid pl te wre further reriuced und wre nowren the posterior linit of the cunsule, resulúne in a more cephlic exr tension of the olfuctory ore n bejond the forebrwin. In contrest to the closod cuprule of the orlier st wes, thut of the dult is decileâly open and a large five-sired expexposes the on'ire dorsal surface of the nuw I organ. This g p is the furdhor result of the process of resorption of curtilwe which berin jun the ewrlier wtage in the formen opnosite the nasel wentur. From this point the process his continued nteriorly, lutereuly knd posteriorly until wll that now remains of the complete c prilane roof is a slonder bur of cortiluge, the dorsul process (i.p.), minne 

diicgoncily across the nasul sac from the plato coterine tcooson's organ, to the postorior angle of the arsal surfuce of the curola (c.). The fused elements of the lumini cribose che the antorbital process wre reduced to u broud bend of curtil ce which, currine oblievely forward, forms a roof for tho choun and the leweril aspects of the main nusi aic. This bank is pioreed by theo foramina through which the nerve and blood ressels, mentioned in the ourlier stage, piss. The fenestra infre-conchalis is noro elongate and completely contains tho orgen of Incobson. The further modificution of the b nd of curtilige uniting the limin critos to the cornu in the exrlier ctuges, which now unites the dorsl process wore described to tho later. $1 \mathrm{~m}$ rein of the comu, is piorced by w sm II foranon through wich the rurns profunums pesos to the exterior. The cupol is more comlotely forme? nit the nuil orening is moro 1 tercil nd somomint dorsil.

whe fin I stuge in the choncrifiction of the nas. I cuncule of imblystom is evidenty i snecicuidtion of curtiluce structures present in the eirlier stage. The ethmoid nlute, nusol sentur and cristae tribeculorum become erewity reduced, while the nedin nus I procoss, Icmina cribos and wtorbitul process become retIy speciulized. The Ereatest chinge in the dult hes occurrod. unterion to the septum nusi where the medin n. Sul process and the cornu trabecul e he ve oxpinded into a comleto rult orer tho anterior purts of the olfuctom suc. With lure tentral gip from externil nares to cro ne, wh worw cupoli: to cribosa, the cansulo is now moch in contrast to the closed type of ...II the exrlier st ces. 

sal mondra raculita.

In a lirva of Sin mendra maculita, $25 \mathrm{~mm}$. Ione, cloninificution

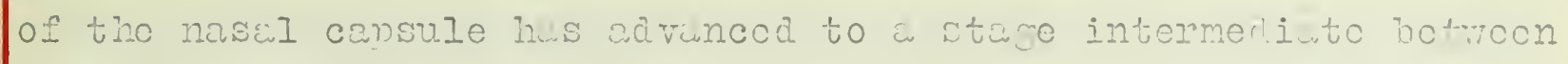
the $25 \mathrm{~mm}$. and $54 \mathrm{~mm}$. Lmblystom lurvac. The frohecul-e with weIl develond crows ortend to the region of tho ntorbitul mocesses

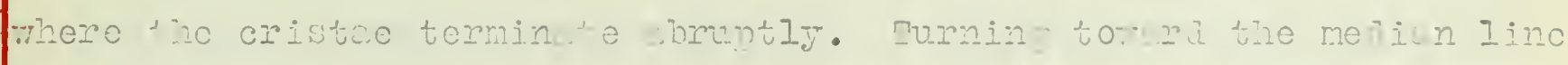

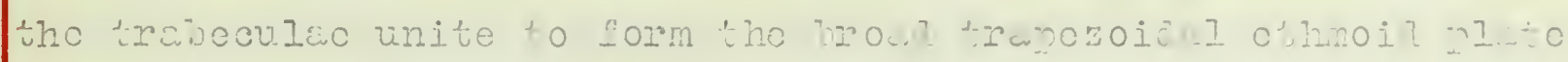

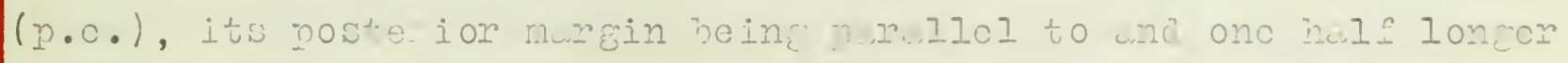

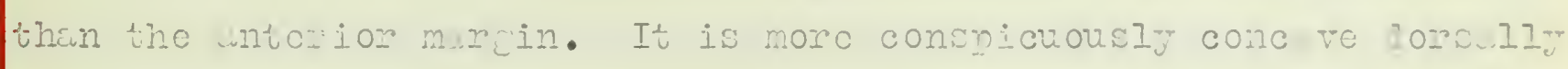

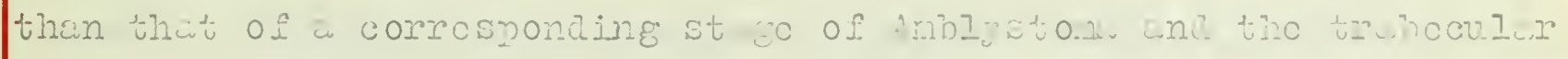

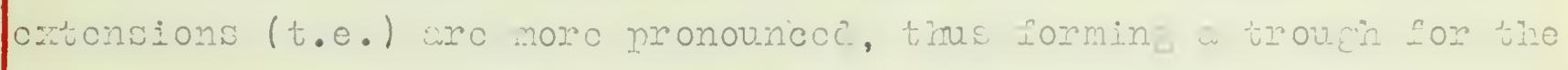

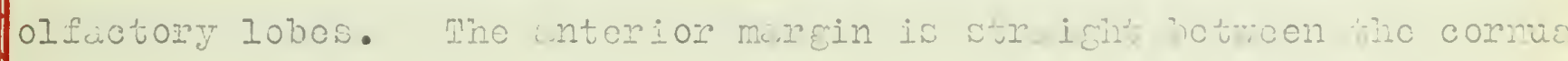

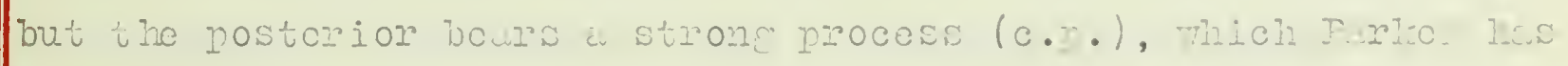

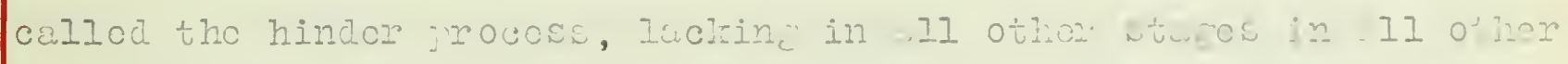

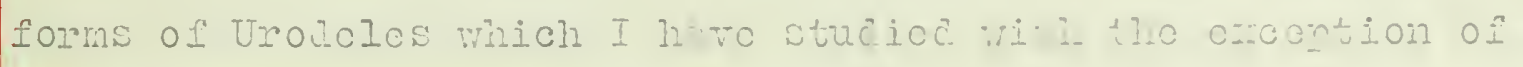
sinclc stace of Crypounanchus.

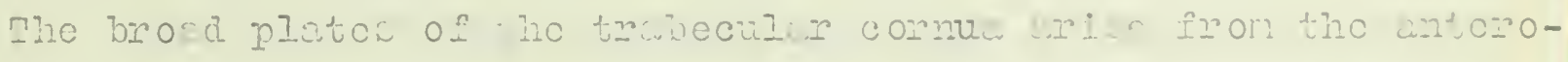

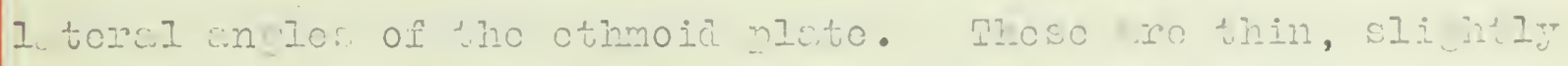

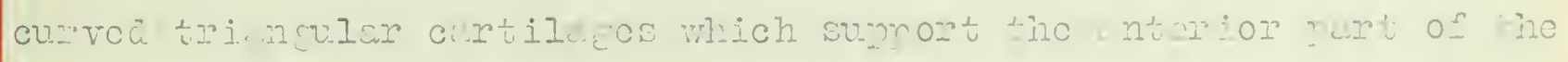

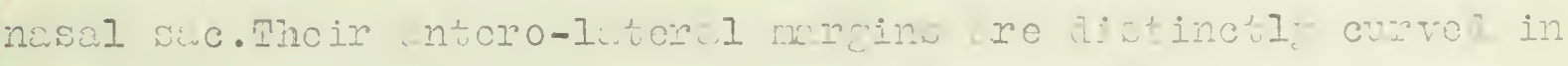

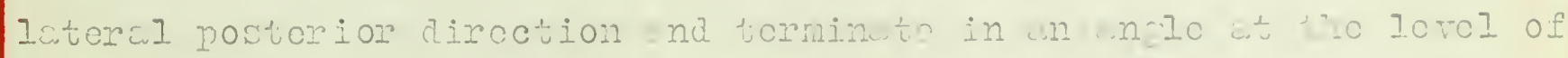

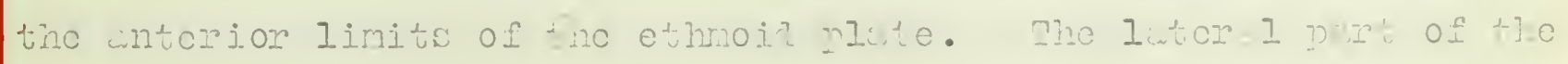

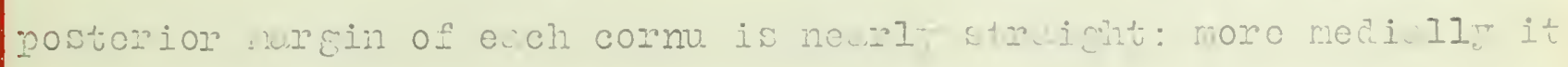

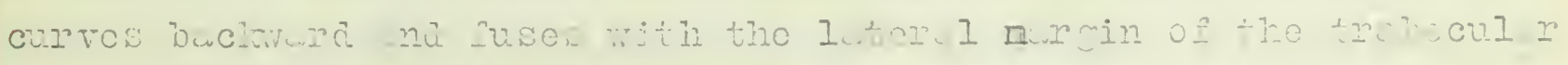

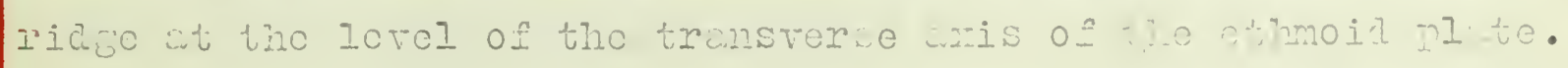

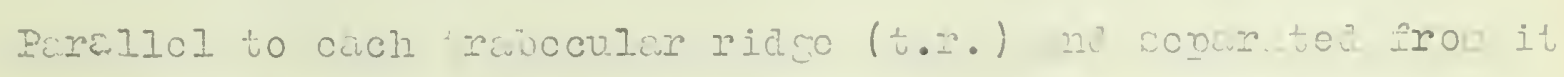

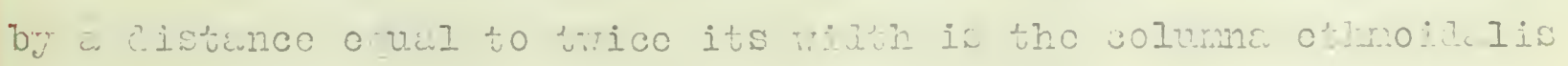

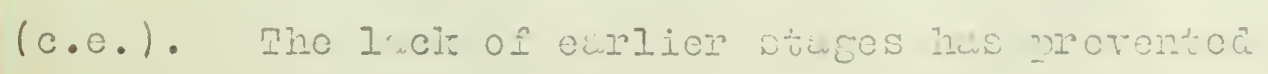



of the oricin of this colum, but I m inclince to beliote thut it urisos from the modiu mersin of tho comu nd thon croms posteriorly

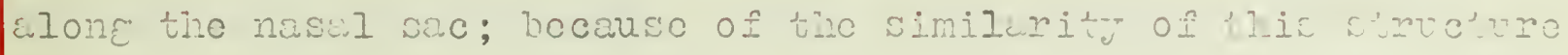
to that in wpolorpes in mich the colume wrisos from the mori. I mirsin of the cornu. This is in contrast, howover, to the inienonions origin of this ber in mblystome. The fuston on those bers is not the sume in both c prules. The cthmoidil column in thing ons unituo to form un cthmoidel bridge bofore there is connection ith

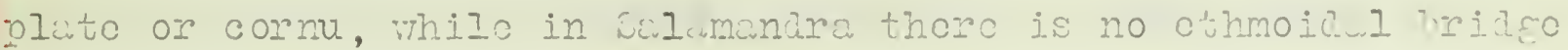
formed. Continuing powteriorly cor columa ethroil lis rects

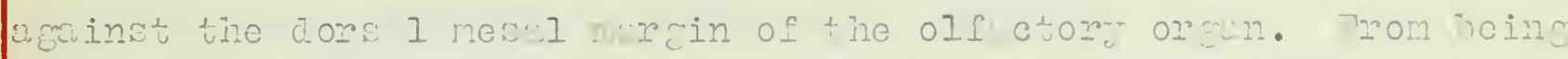

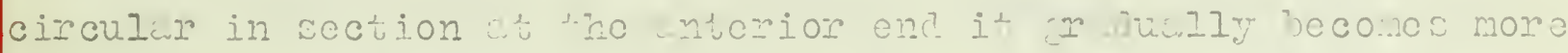

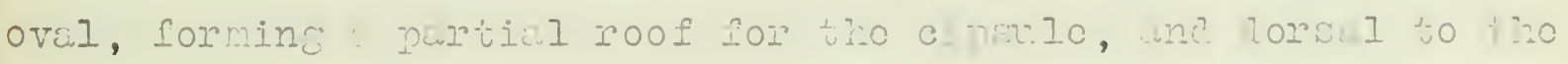

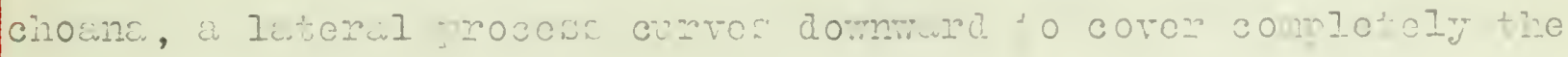

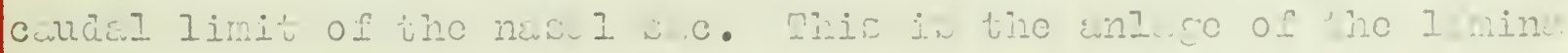

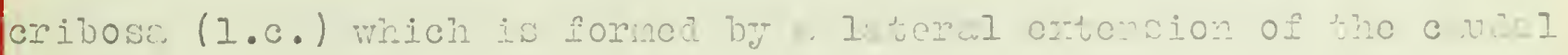
end of the othnoidul column, so vell covelone? in the lutor stere.

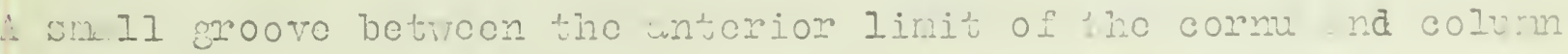

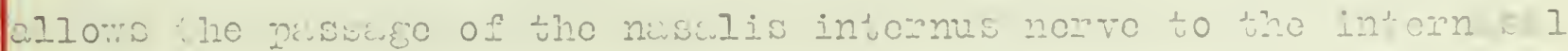
spcice.

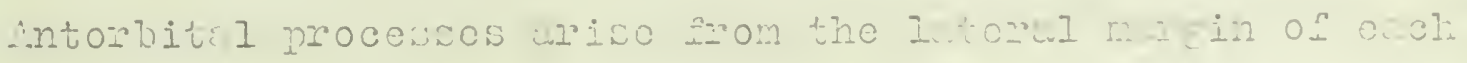

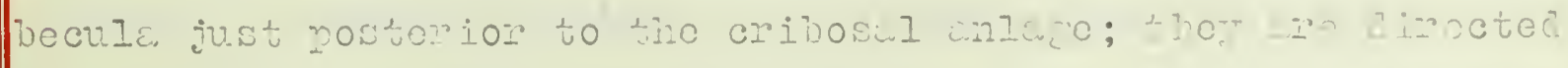

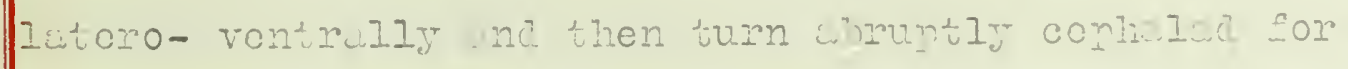
ocuid to the lonetr of tho mrocow wh ommin te th tho lotol of the candul morin of the cthmoic nlato.

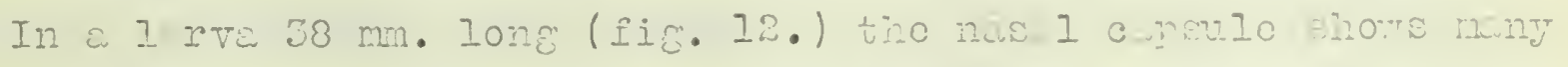

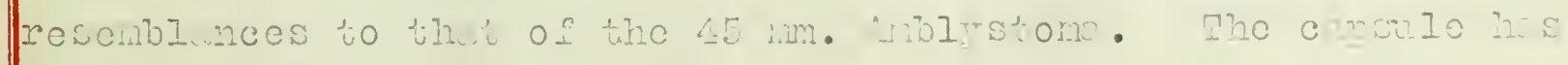

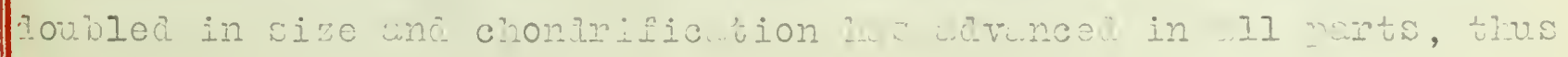





\section{6}

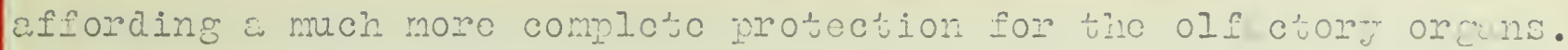

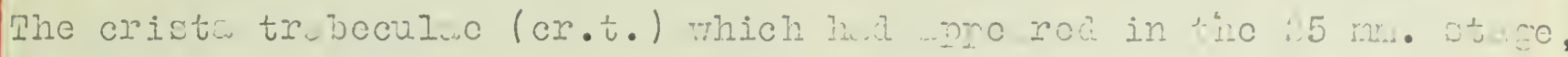

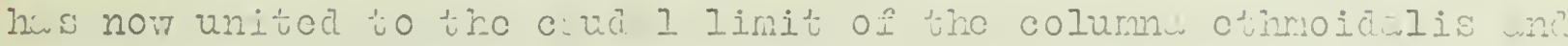

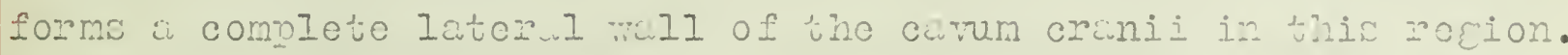

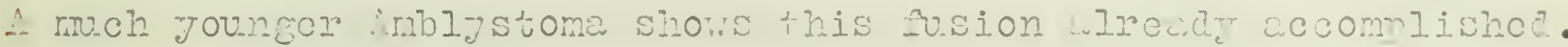
The cthmoidal plito (n.o.), though trupezoic I in out Iino, has

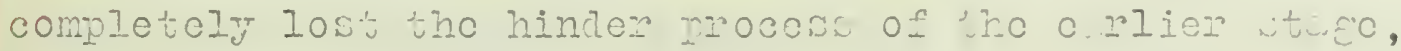

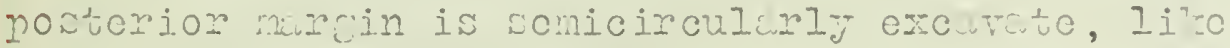

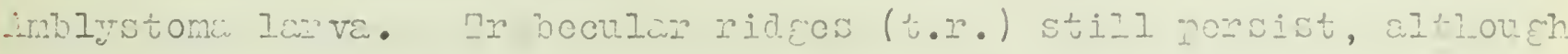

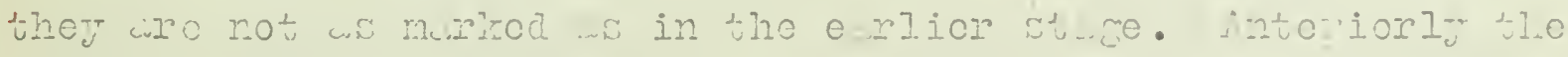
otrmoid plute continuos into tho n. ect wontrme

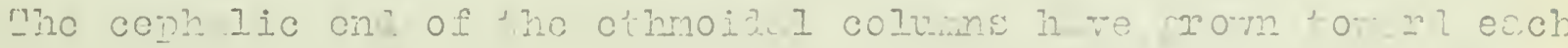

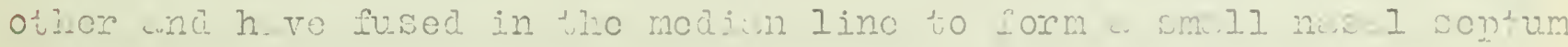

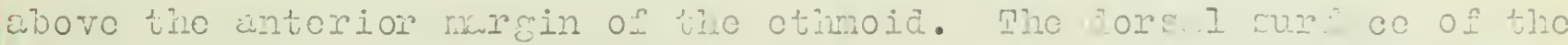

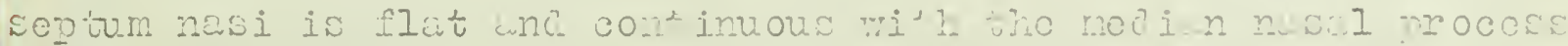

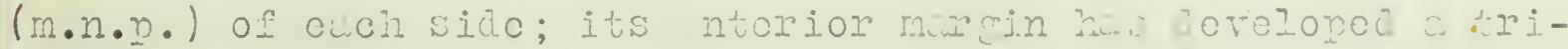

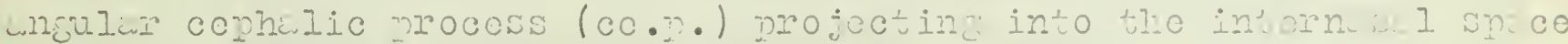

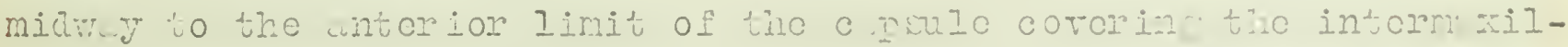

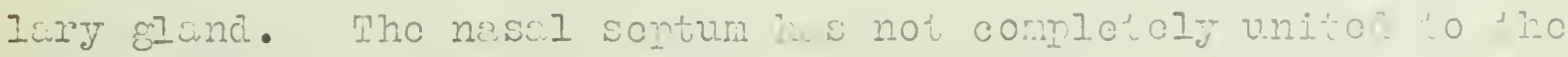

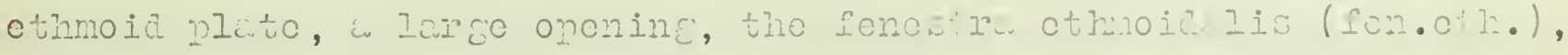

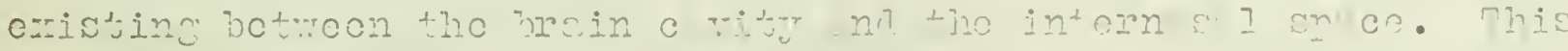

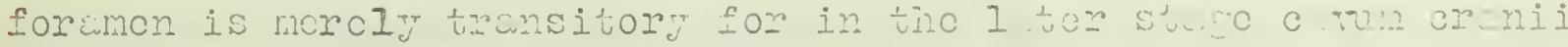

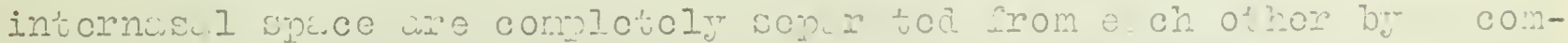

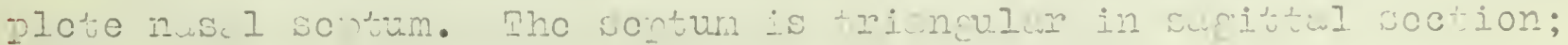

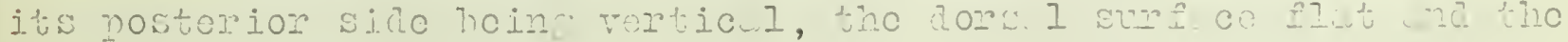

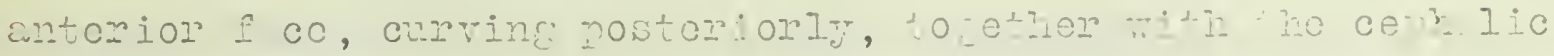

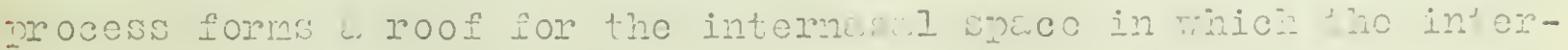

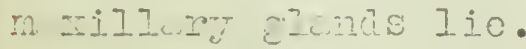





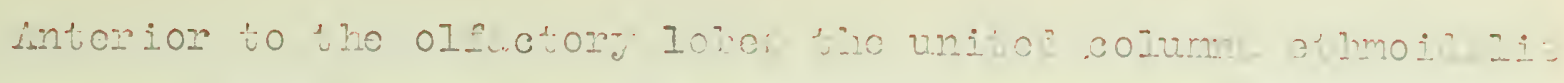

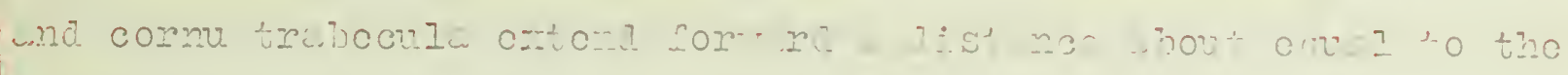

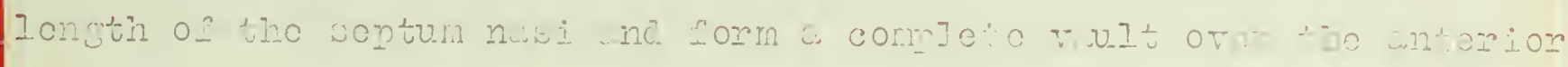

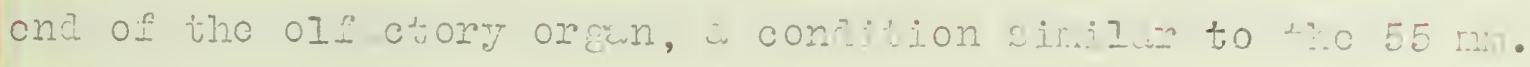

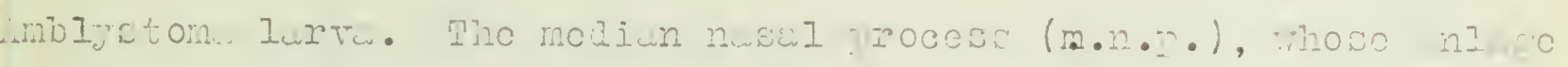

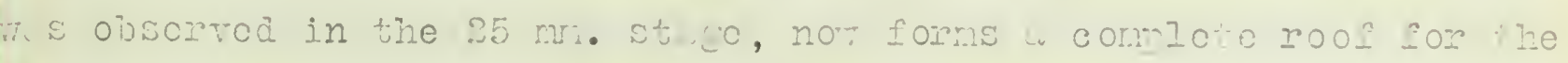

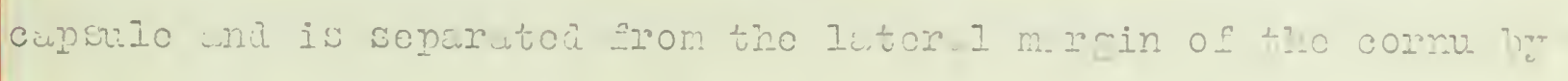

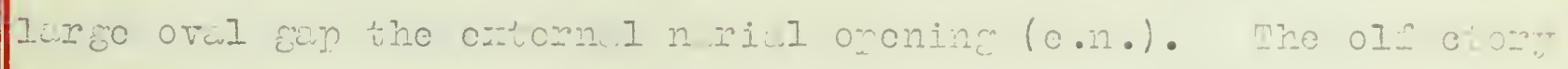

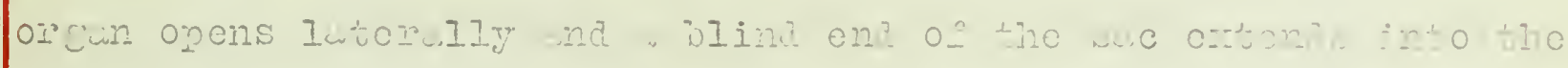

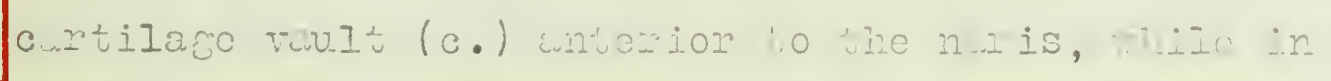

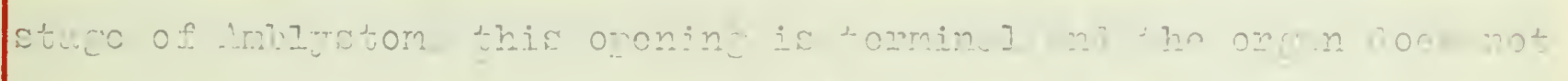

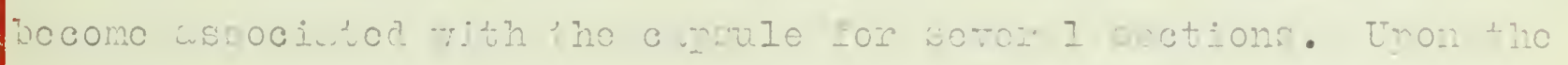

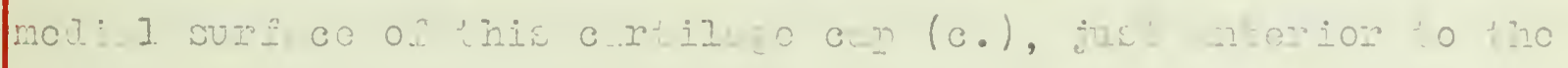

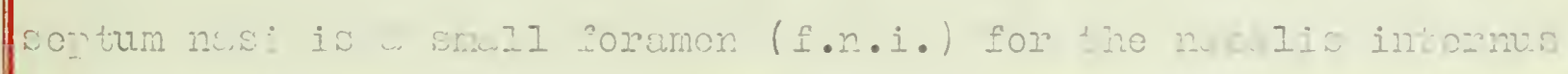

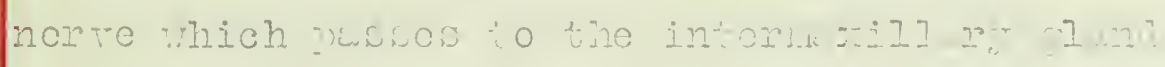
(I.c.), which nos no

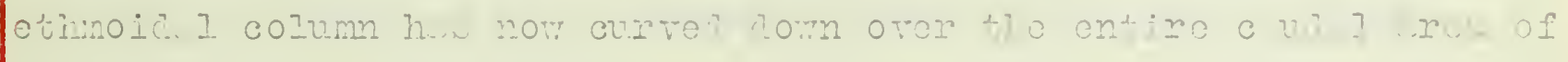

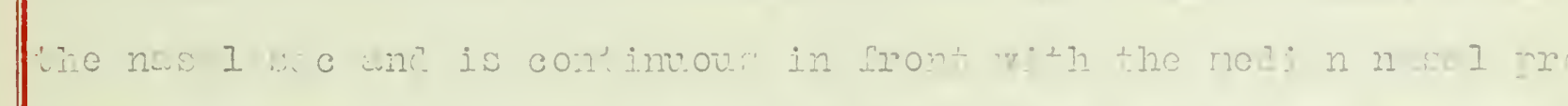

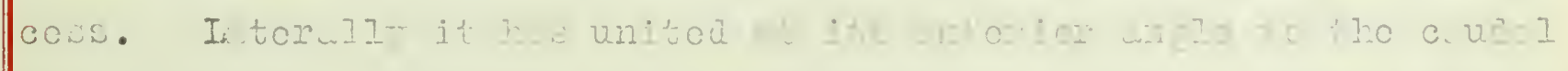
Iinitu of tho cornu, thus fominc a completo b nd of ortilusc roun

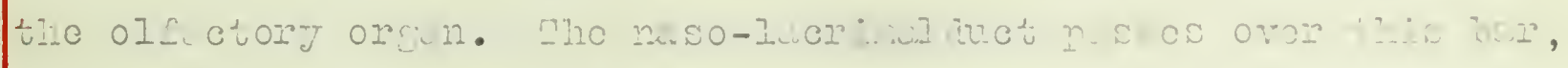
diticios into two tubos, estributod to who innor nelo of the oye

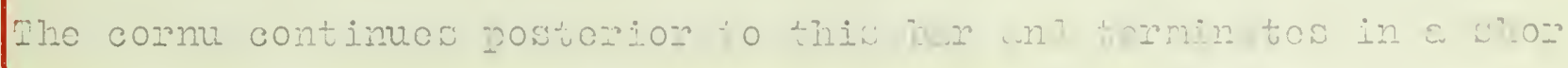

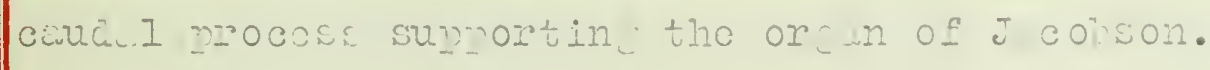

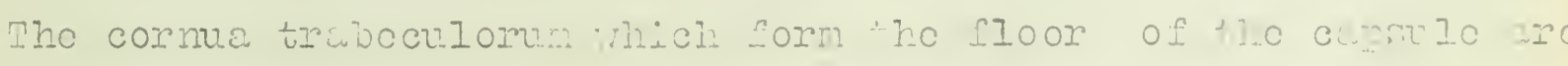

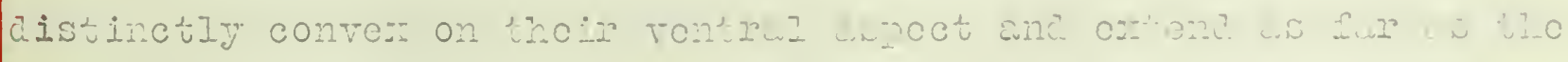

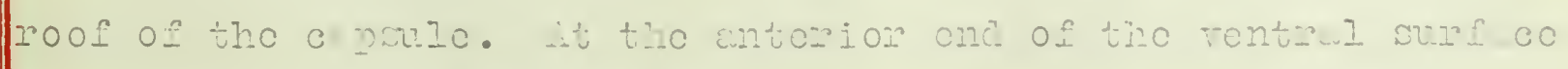

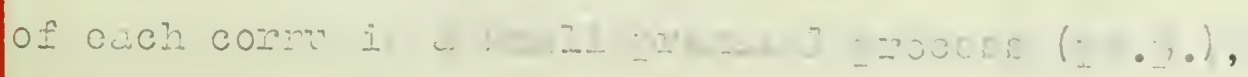





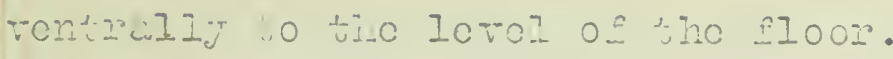

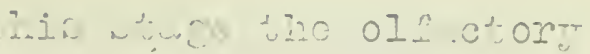

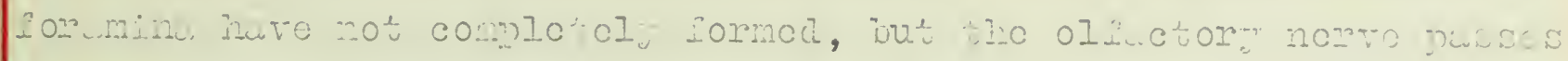

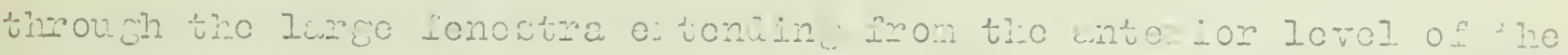

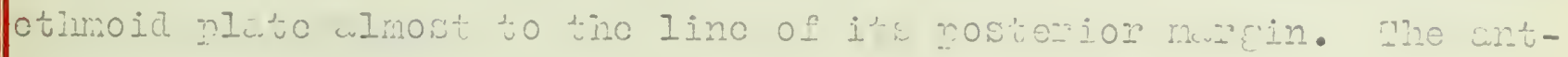

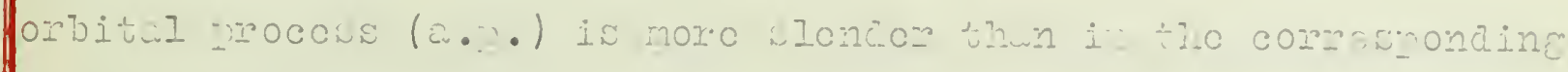

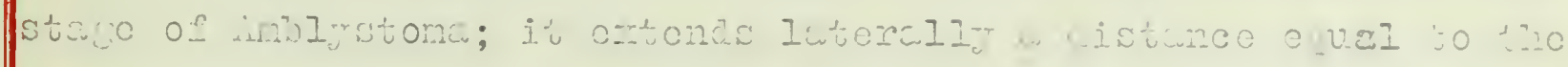

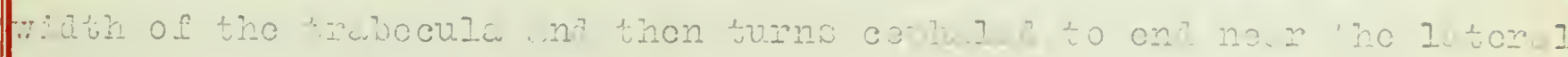
murrin of the I min cribos.

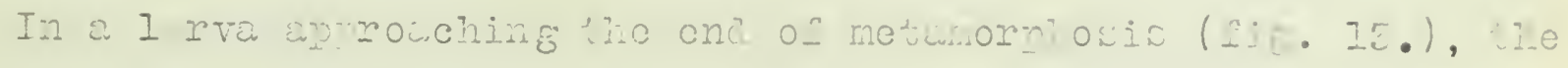

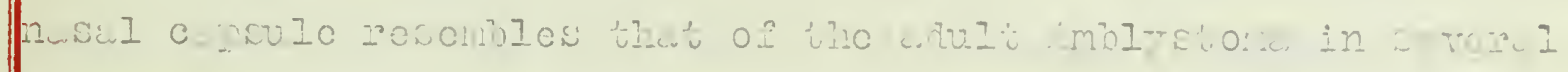

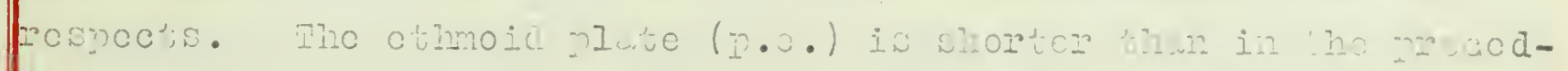

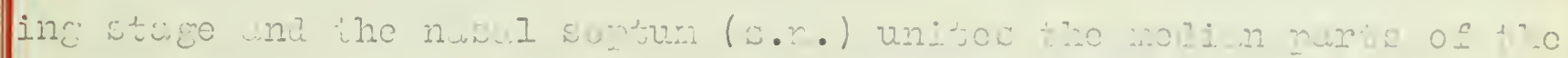

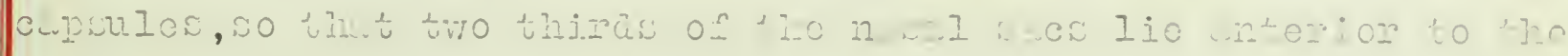

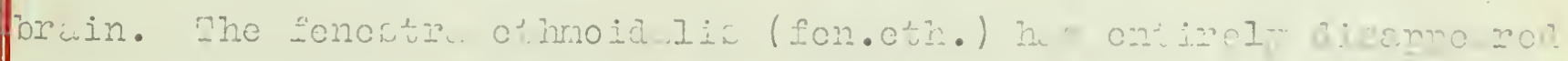

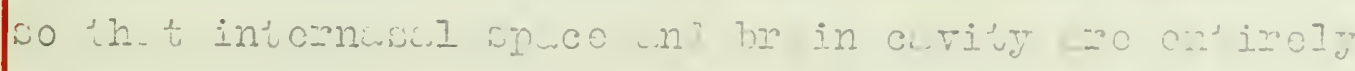

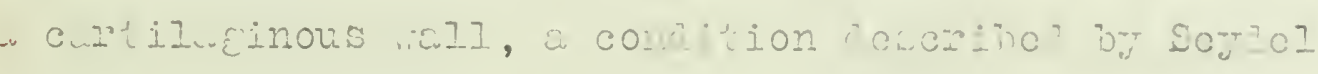

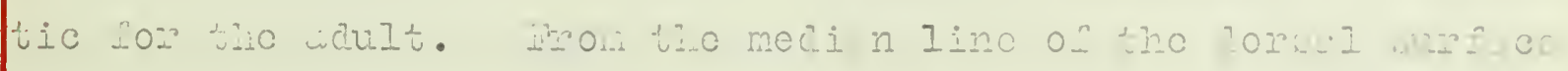

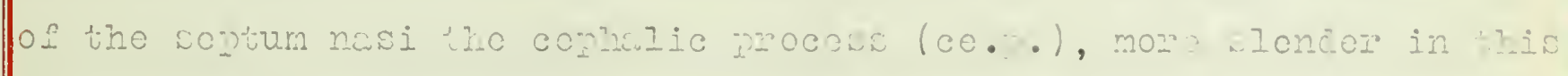

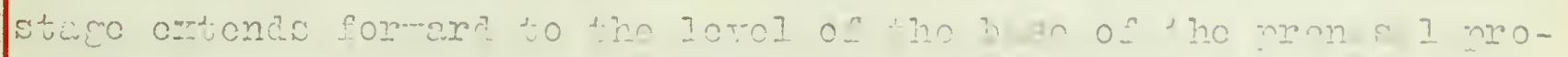

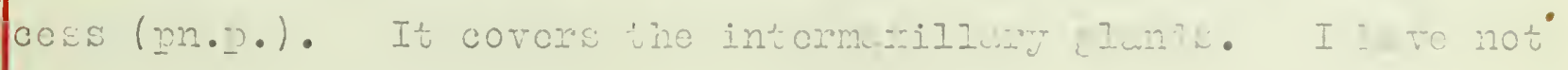

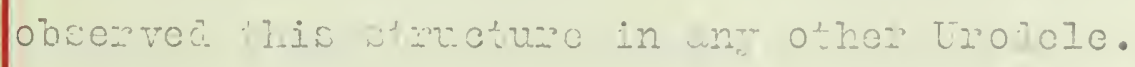

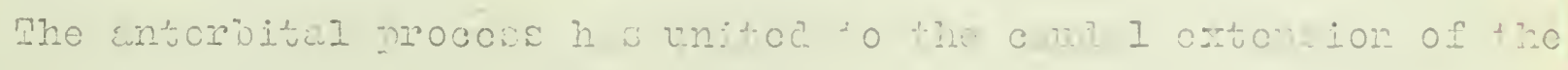

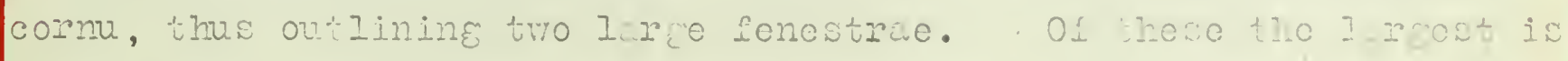

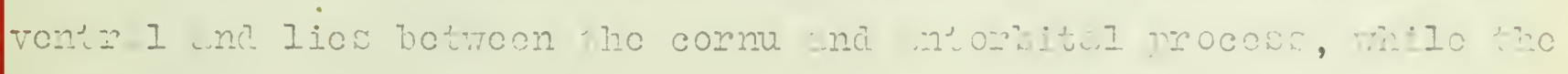

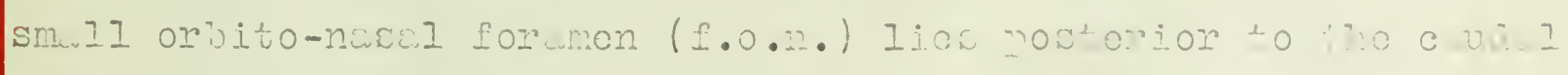

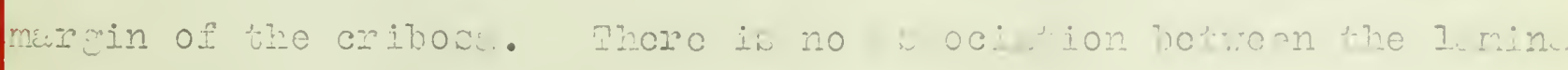

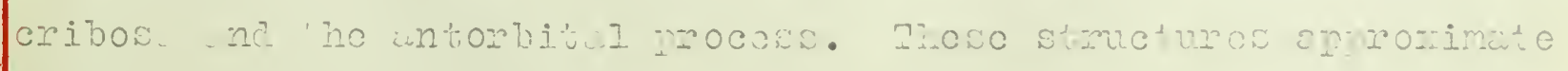

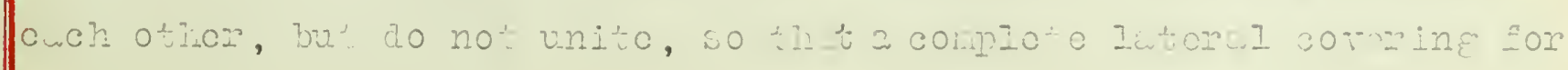





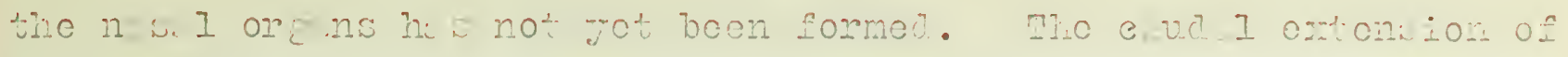

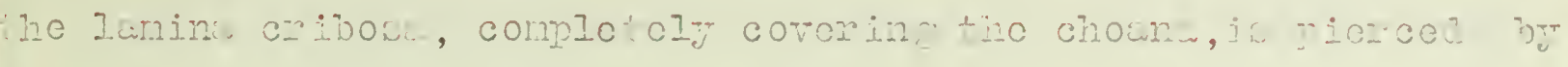

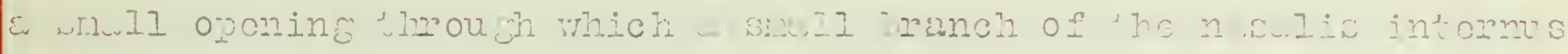

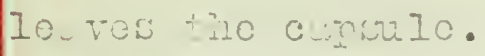

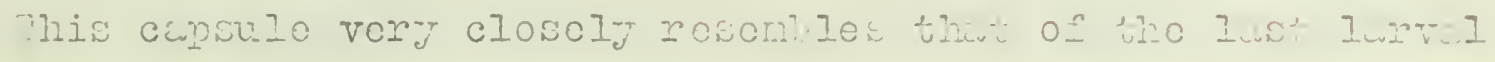

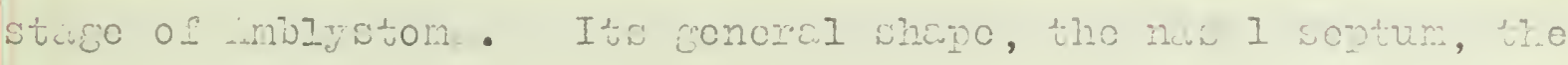

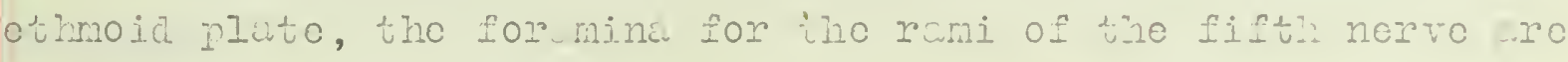

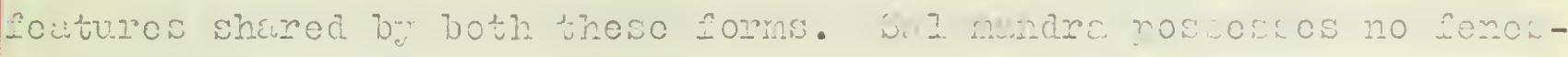

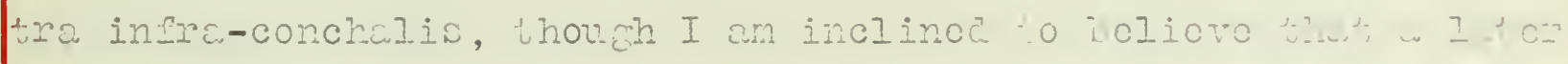

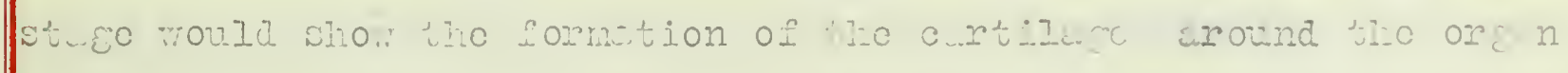

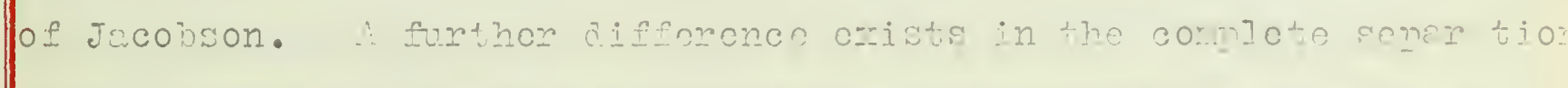

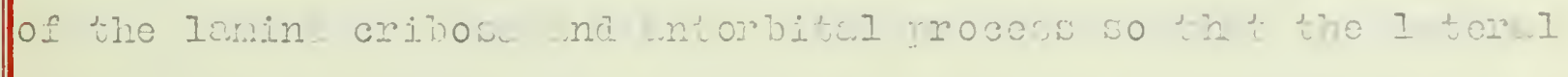

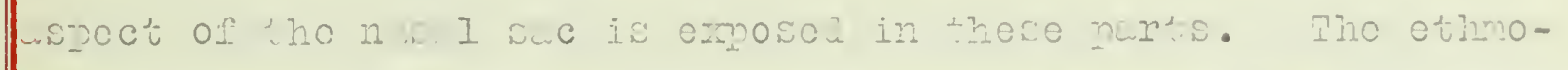

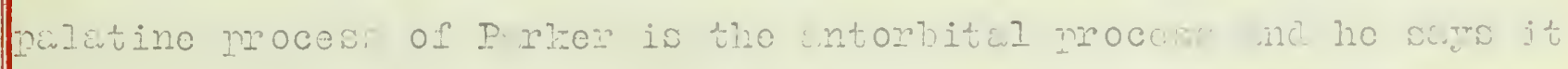

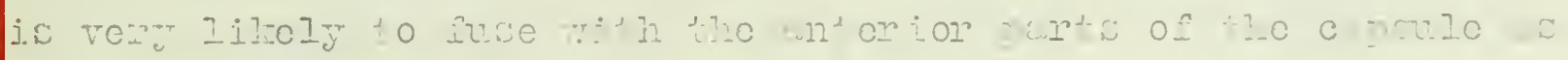

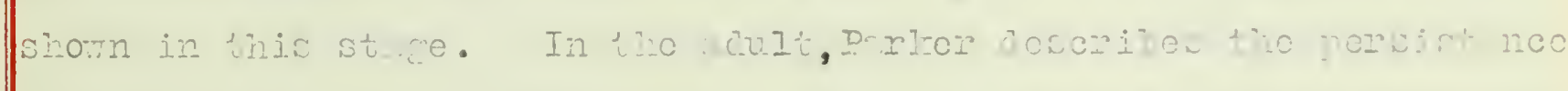

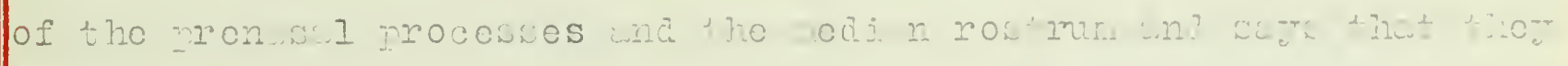

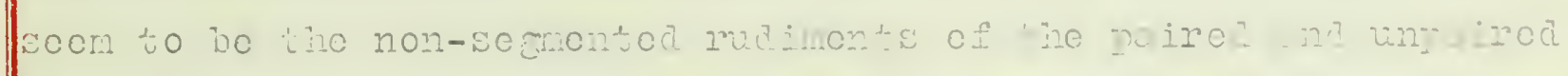

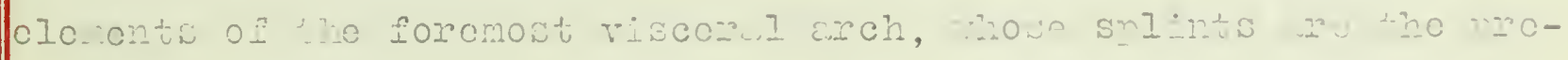

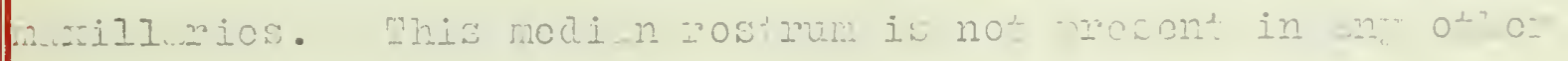

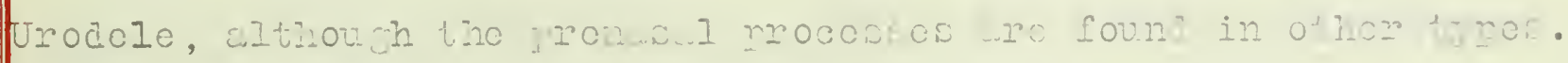

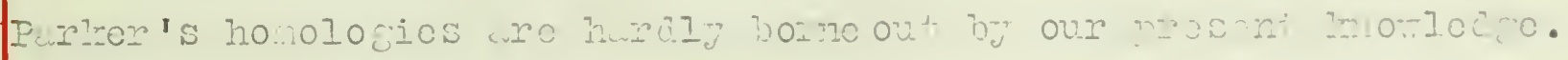



Mriton criécatus.

The nisul cupsule of Mriton cristatus, thoun bewing sone resemblences to those of nulimentre wnd imblystorid whows many stril-

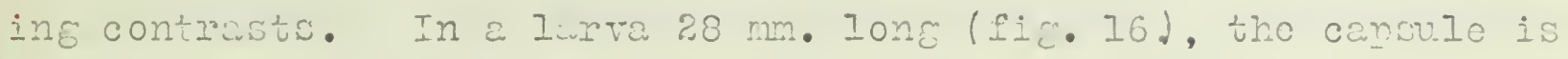

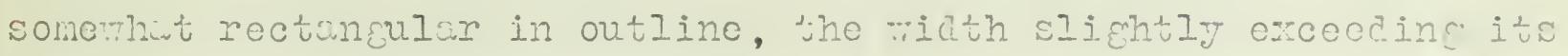

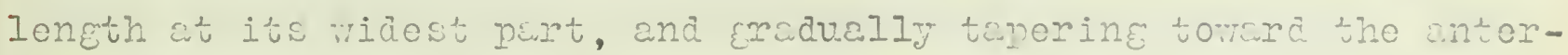
ior end.

Lt this stuge the urabeculur cresta(cr.t.) are *ell aerolonod,

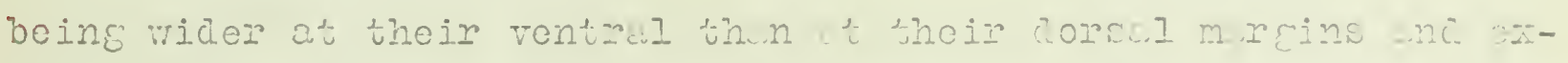

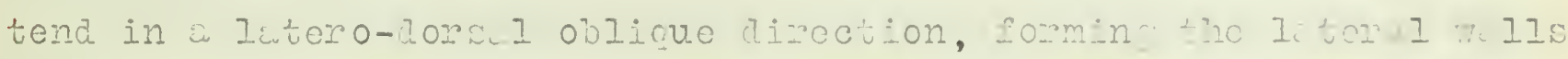

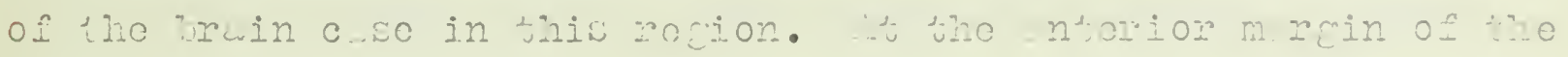

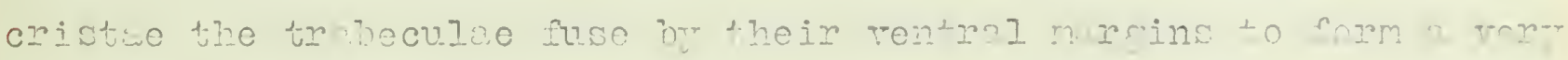

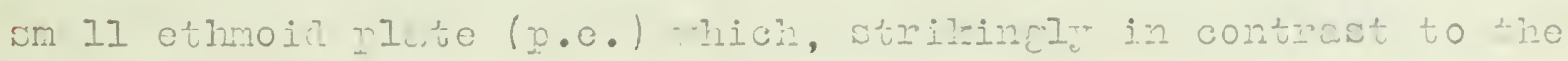

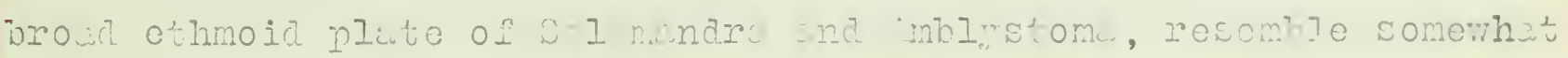

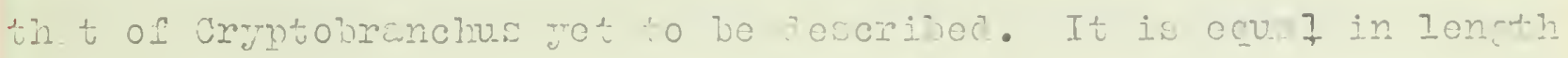

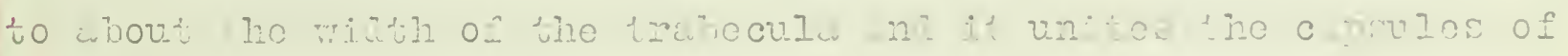

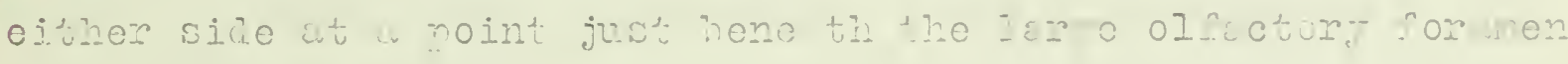

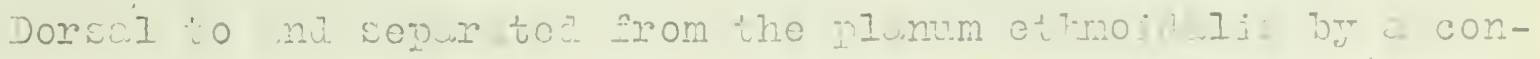

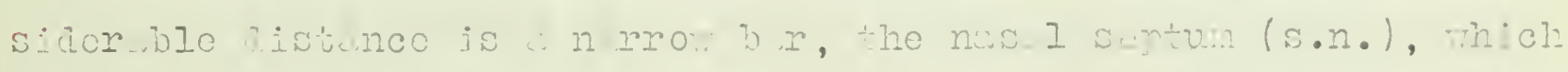

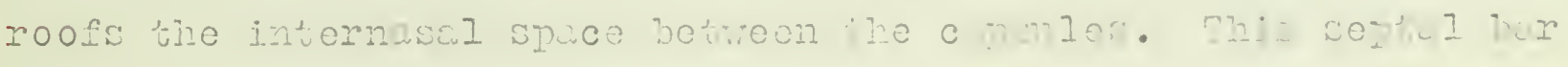

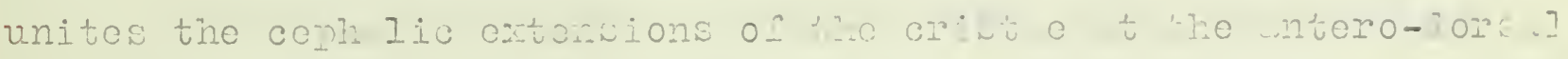

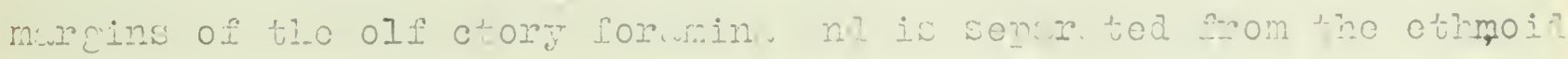

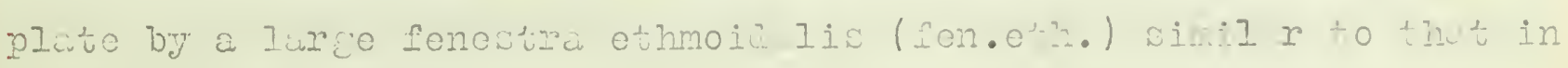
the $58 \mathrm{~mm}$. Sin 1 m ndr...

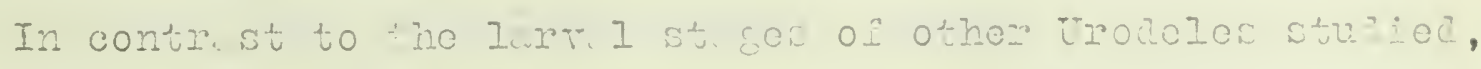

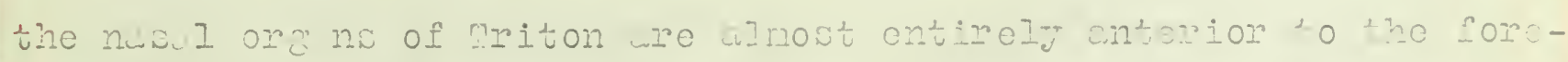

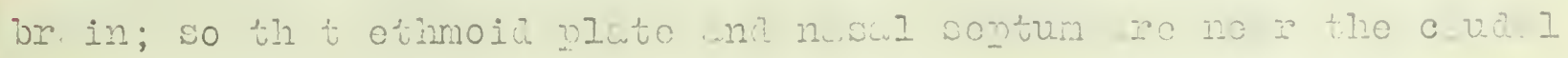

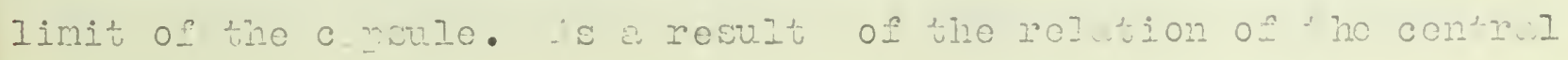





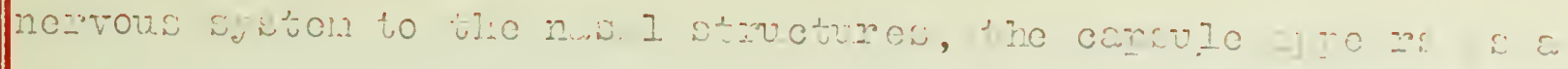

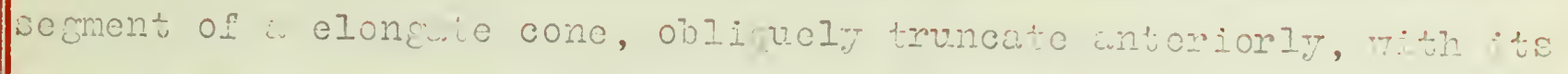

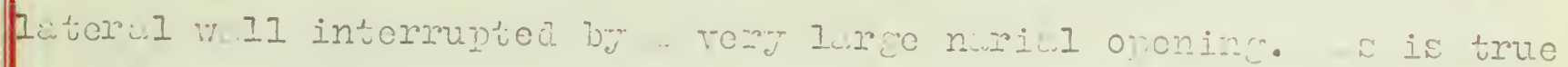

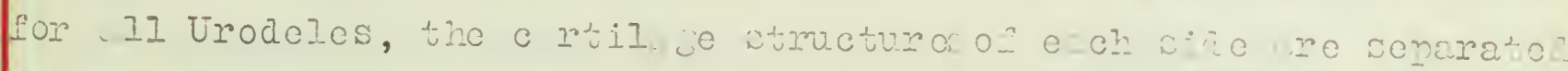

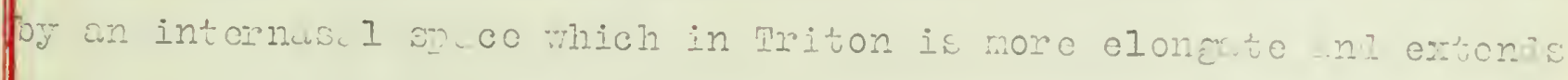
petween the walla of the whterion two thimas of the cunle. Whis juternisul spuce, the intern rill ry roon of Jom ( r ry) is continu-

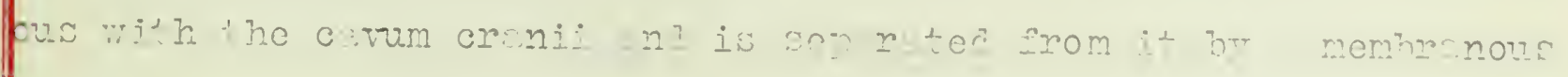
fuctures on Ir.

nterior so its junction with the crist rebecule, the Inine

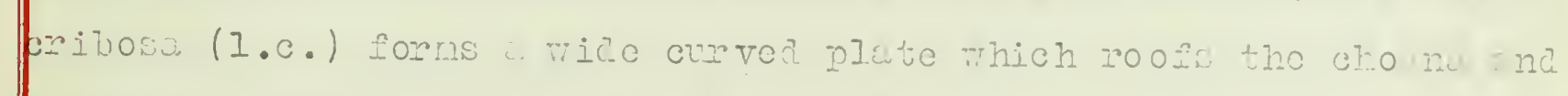

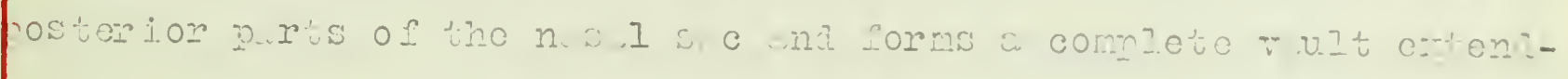

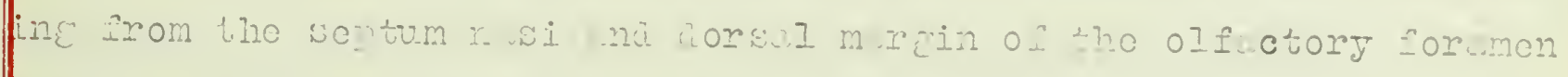

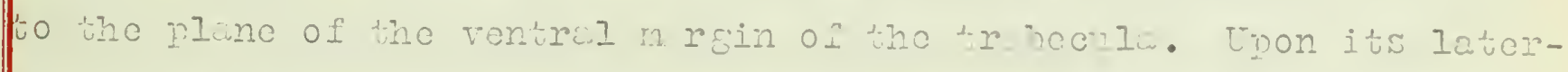

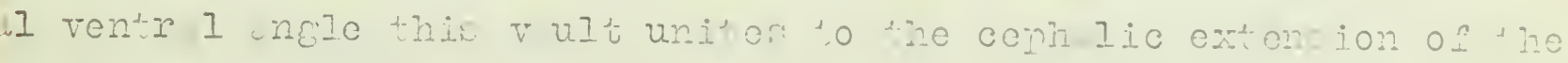

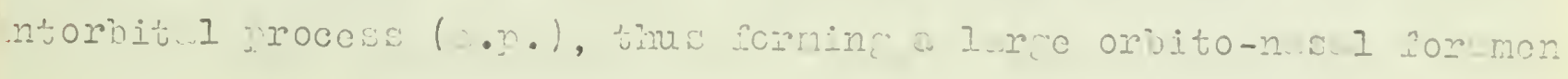

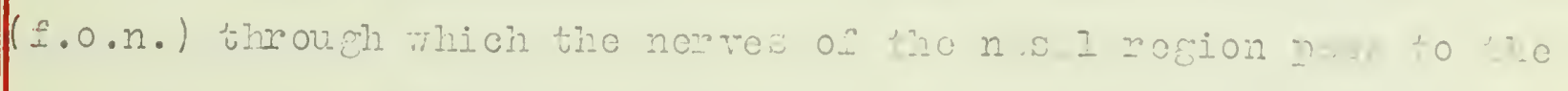
intorior of the cupurzo. - nteriorly lno l min cribos unitos

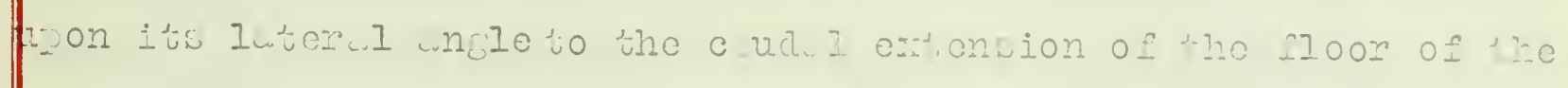

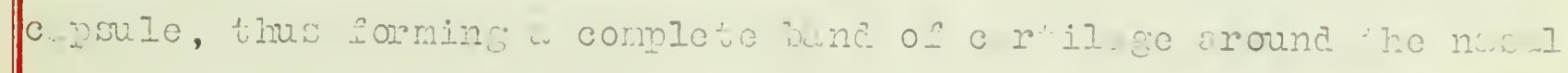

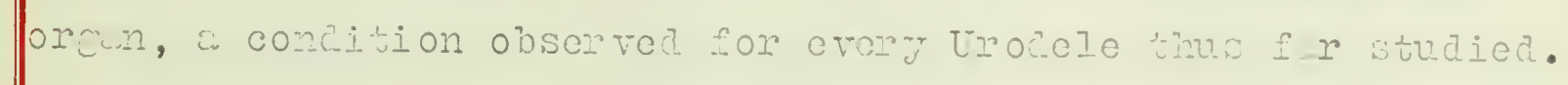
Phis bund is wo swsociated with the orgun of J cobson which lios ppon a smill oztenision of the floor of the circulo posterior to the

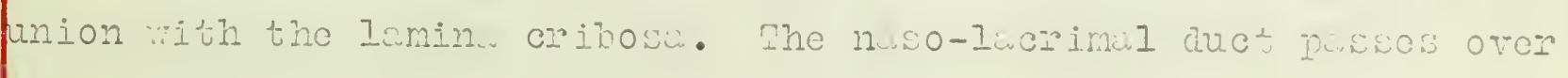
this bar as in both imblystom and 1 mandra.

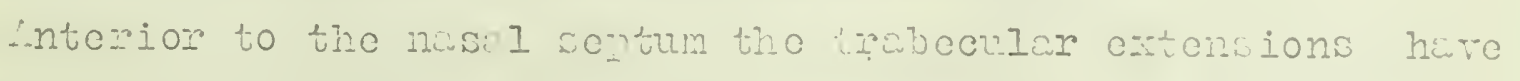
exp nded into a wate which hes mom tentrally to form the floor

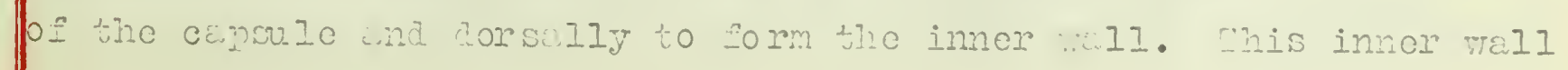





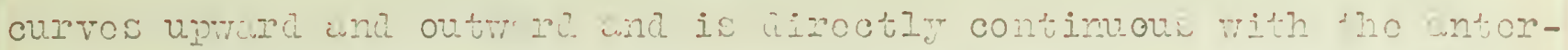

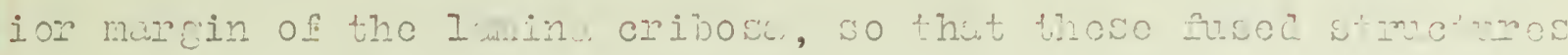
form a complote curtilago roof for tho cunsule, toreor by wingle

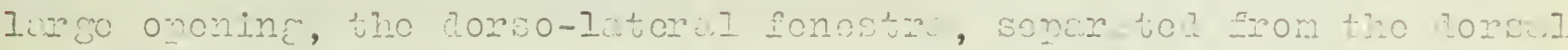

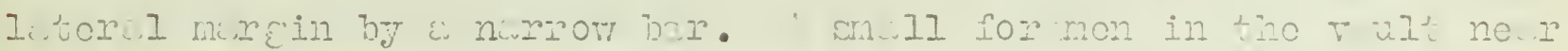

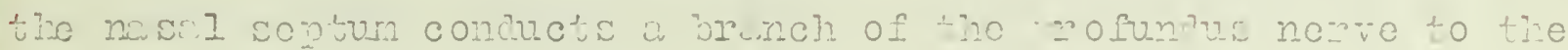
dorsal wriface of the cersule.

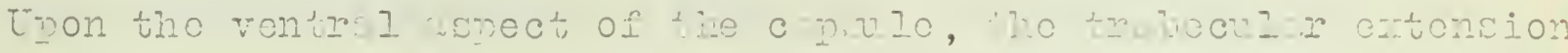

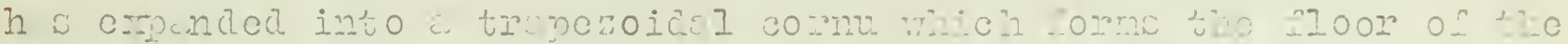

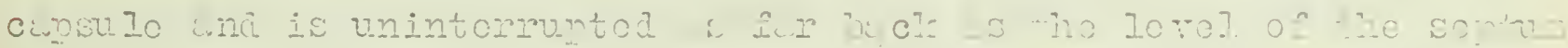

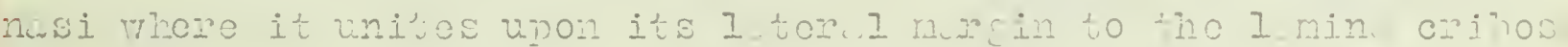
bove described. Lt the ntorion on the floors of the tro c nsules

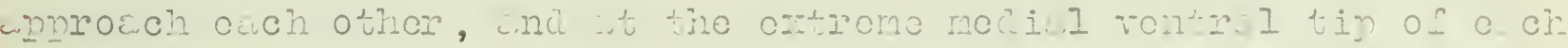

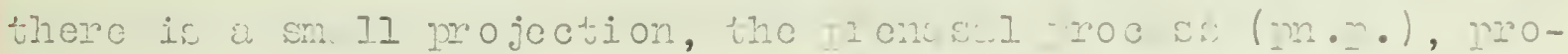

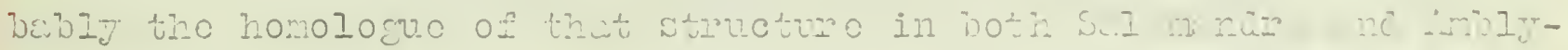

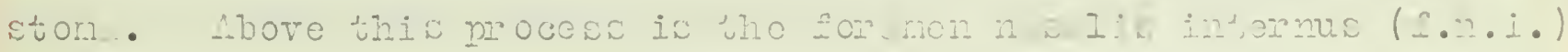

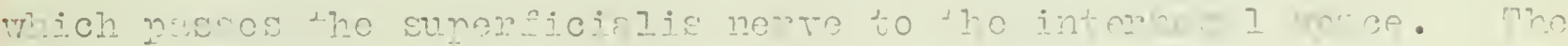

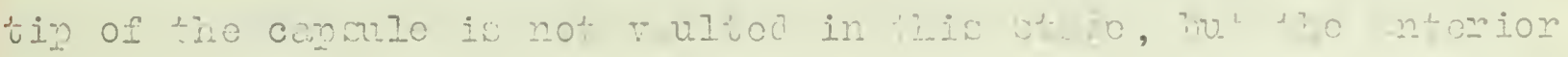

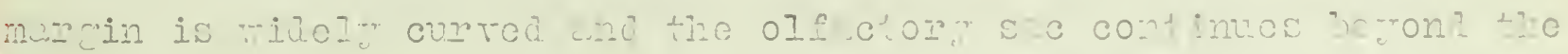

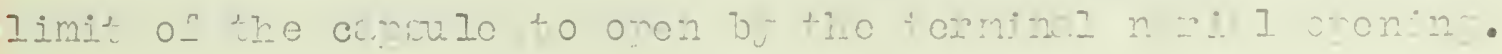

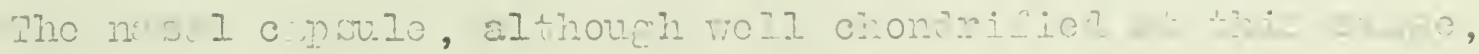

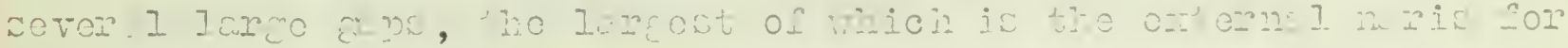

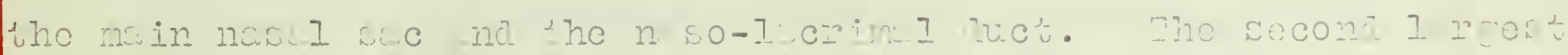

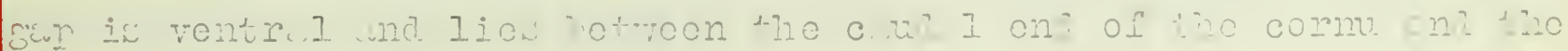

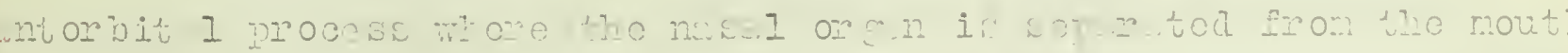

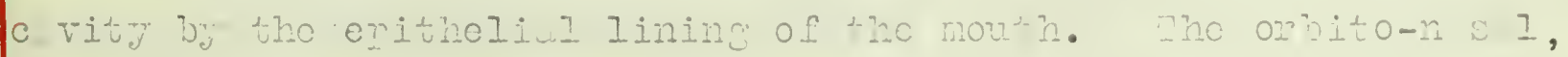

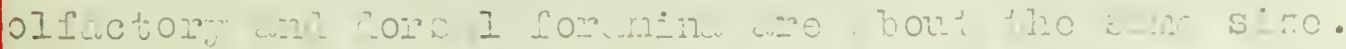





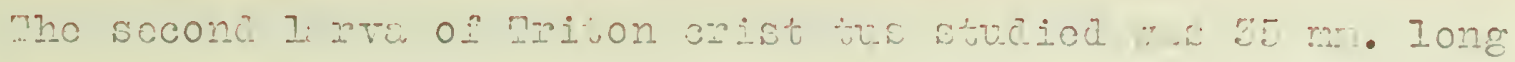

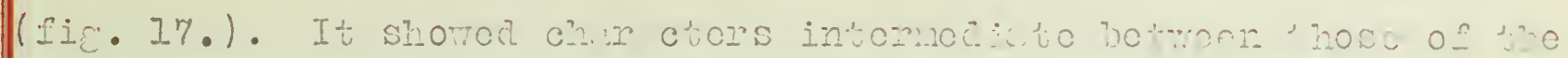

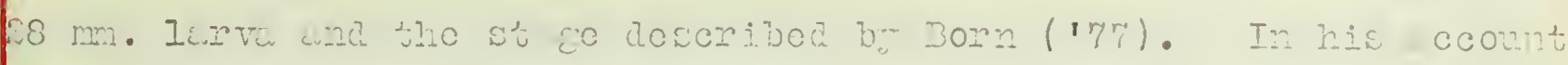

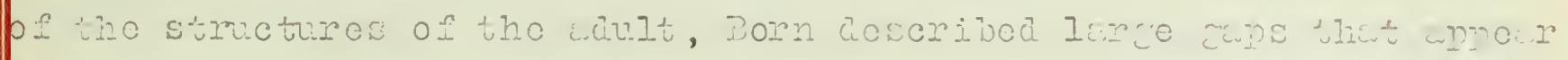

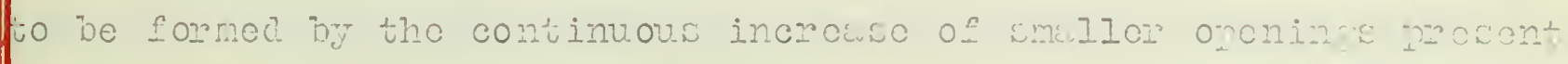

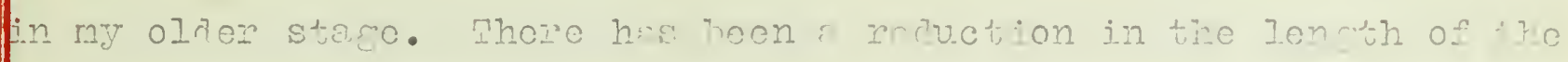

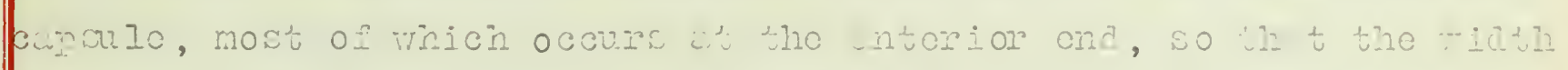

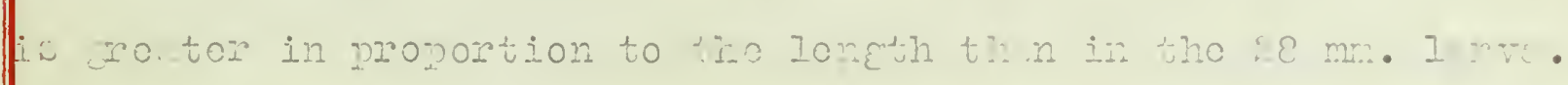

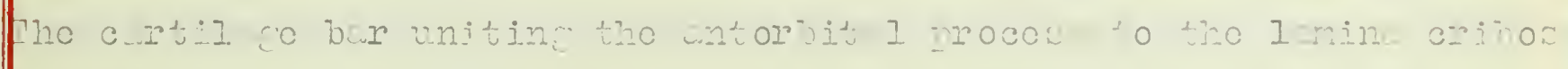

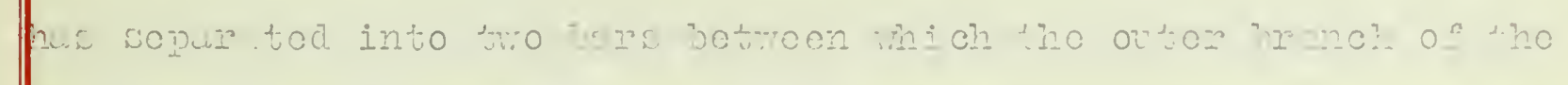

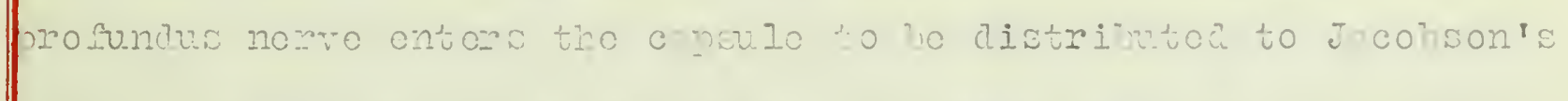
prewn. The brein lios l cral to the covili. fourt?

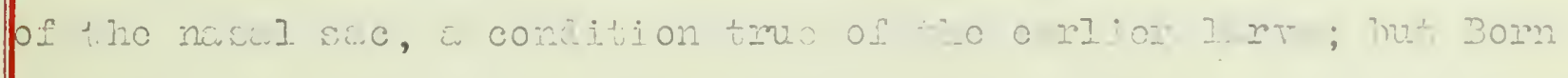

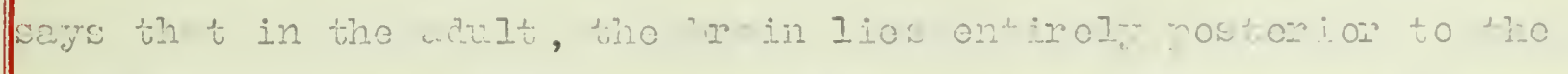

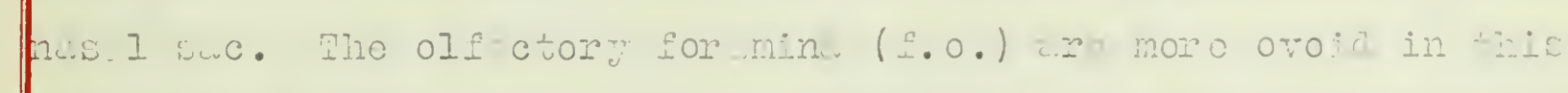

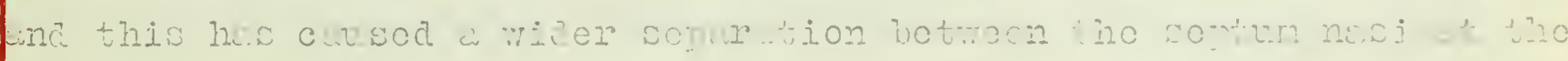

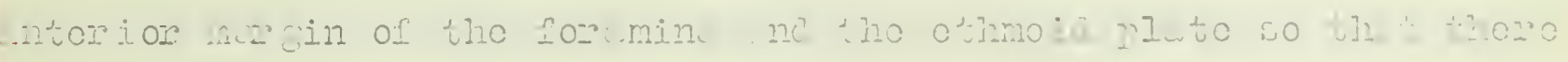

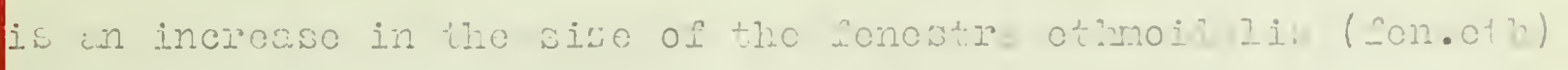

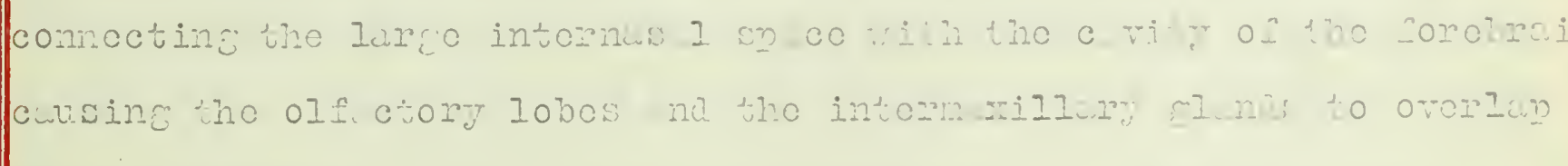
in this súce.

Anturior to tho olfcetore doremon, the innor th

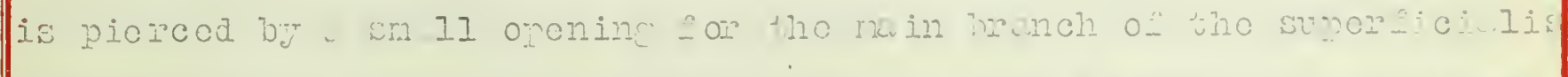

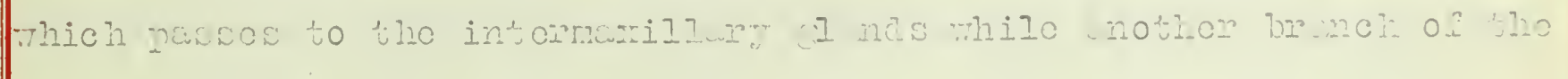

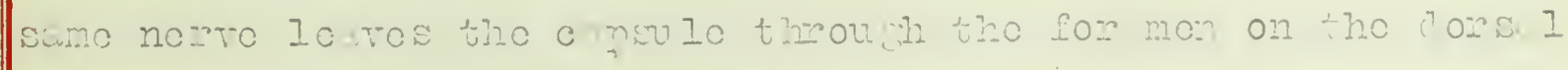

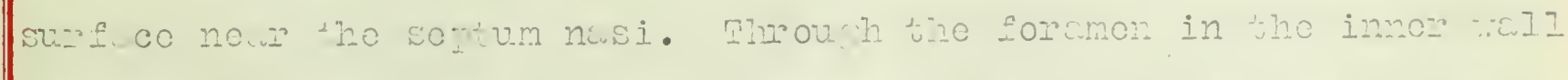

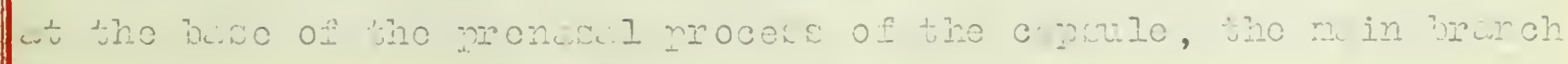

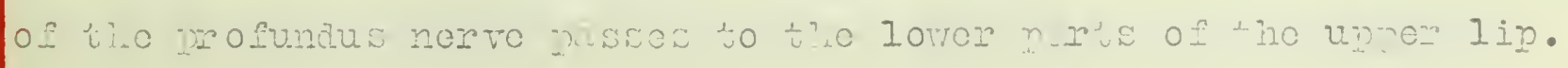





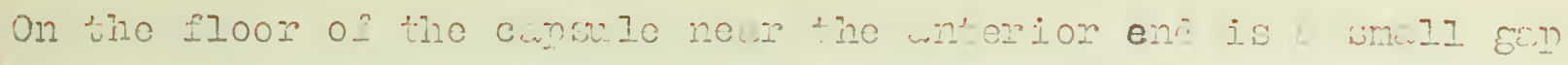

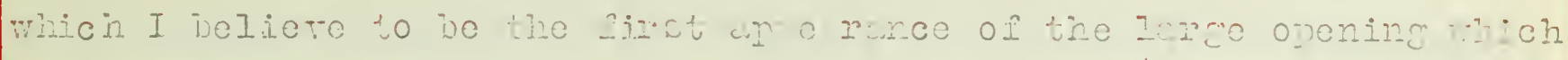
is 'he rosult of further resorption of cruileco, described hy

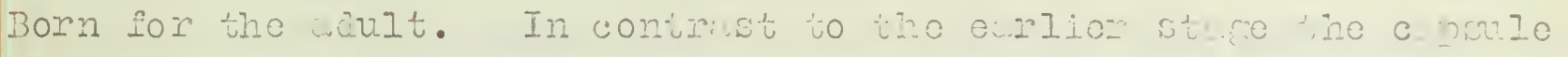
now formis a vult (c.) over the wtorior ond of the nwa I onn nu we

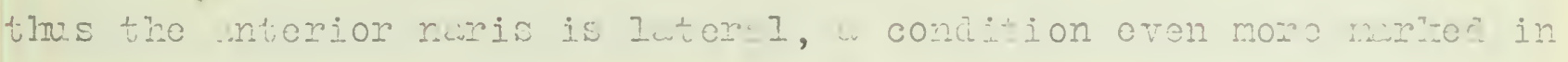
the watu It stuge.

Fo trey to ho:nologize the ftrmetures of Initon misth thos of

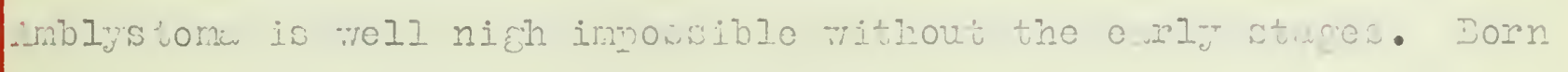

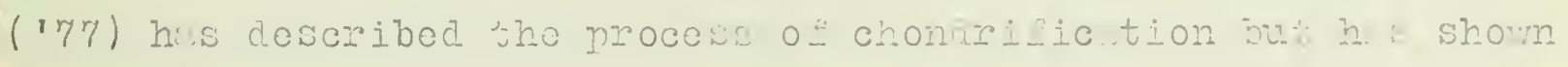

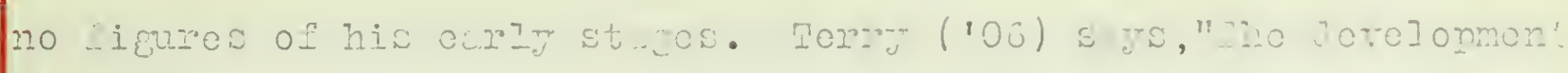

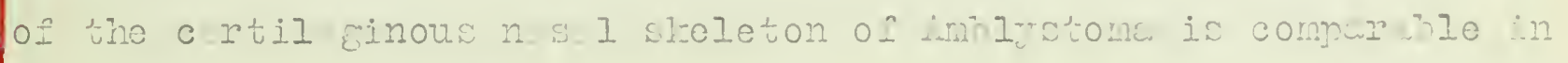

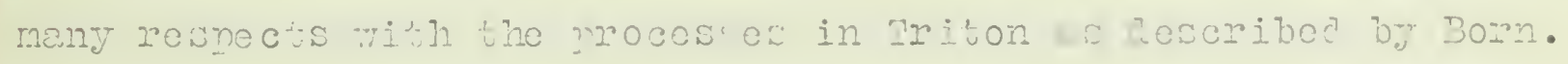

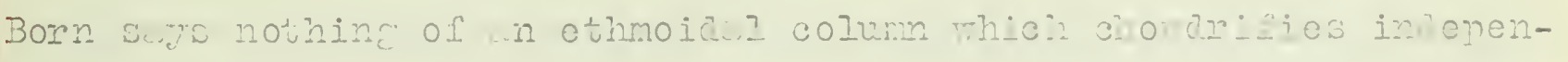

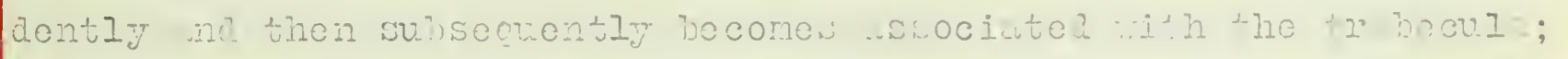

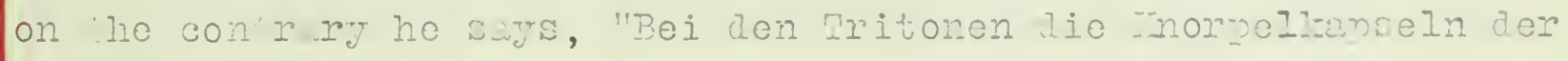

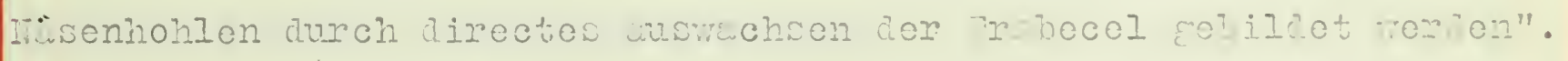
The side will, roof wh floor of the cupsule ha beon forne wy w con tinuous dorso-later. I and ventro-l, teral Erowth frow the trithoculu

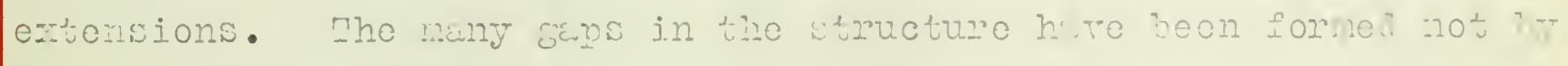

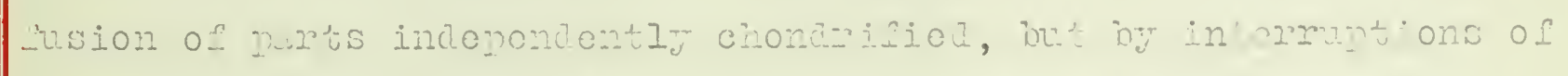

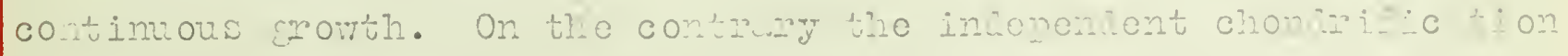

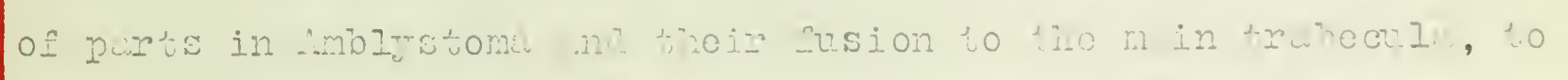

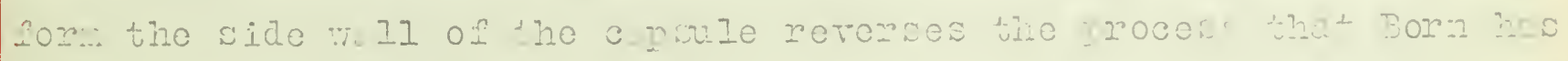
described for trition, wh ret cry conclude his comprison by

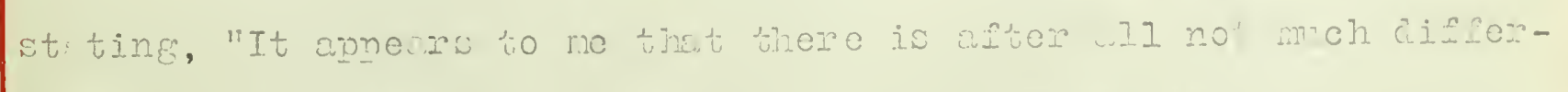
ence in tho origin of the caparie of these tiro wimula." In my

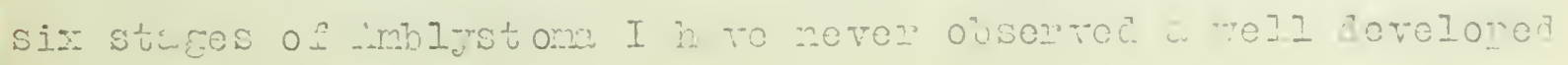





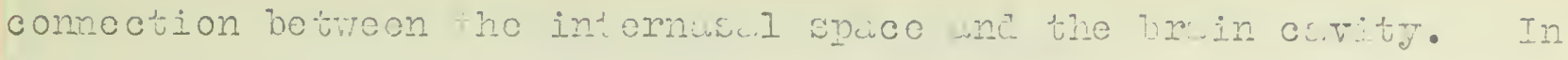
Triton this fonostra is presents in both lurvi ftuces and Jorn a va, "Diesor Internosclroum ist boi Mriton oristutus und tceniwtus, niemas durch eine laborlise wand von der wehädel höhle coschiocion, sondern inmor havtio gegen dioselbe cbseschlosson." I hive decoribed similcr openine in walm ndre where it exists only in tho larvi Stege. It also occurs in tho lerpre of Pelobetes ind Rine.

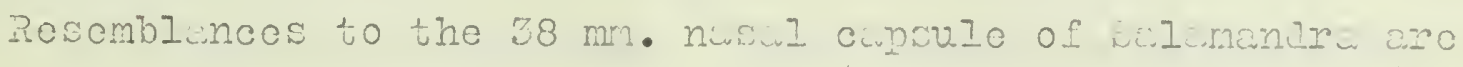
somemint striltine. The cthmois plute, foneatri othmoichlis, olfwetory forwmen und nasul sentum can be rocitily compron. The whtorbitul process cun its connection to the lumina criboe form

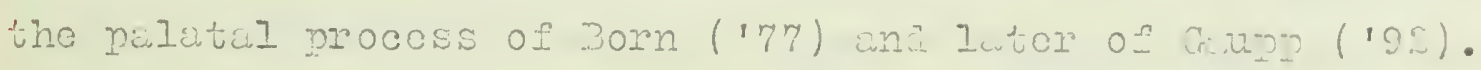
weydel (195) culled the rostorior catonkion of the cornv, w

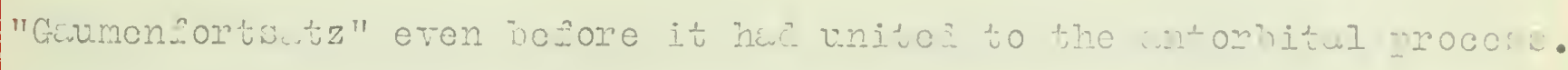

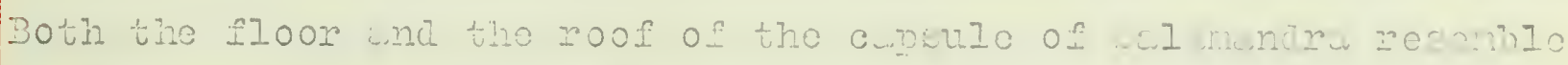
thowo or Iriton, but the whonce of the lono cuns in these writs

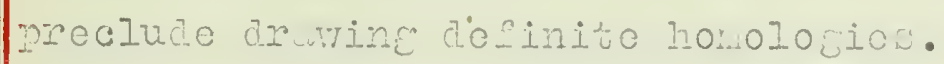





\section{6}

Diemictylus viricescens.

The nasol canale of a larva $38 \mathrm{~mm}$. long (fig. l4.) is woll chondrified and resombles in ma respocts thè of tro $35 \mathrm{~mm}$. Mriton cristatus. In both cuimals the tro cansules aro unjtoc by a vory narrow cthmoid plate, the only connection betroon thom in Dicmictylus, which does not possoss a septum nasi as ioos Mriton. The nasul organs aro woll encasod in cartilure and the samo cans aro well roprosentod in joth soms. In who re ion of the ojo tho cristac traboculorum (cr.t.) aro hish, comlesely seperctinc the ontic orench from tho contral neitous system.

The antorpital mocessos (a.2.) havo alroedr untuor to tho Iamina cuibosa (I.c.) so thet thoso stuructures forn a crror plato Which completel covers the dorsel and latoral parts of the choanal

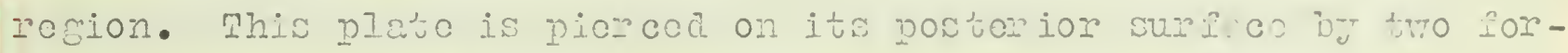
amina, the imer of wich is she on bito-nasal oponing $(\mathrm{s} \cdot \mathrm{o.n.})$ Eor the norves of the nasal roion and the outon is smaler an?

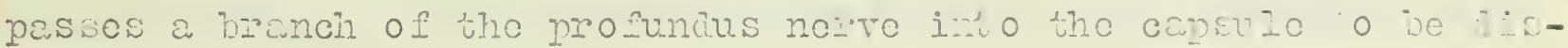
tributed to Jacobson $\mathbf{1}$ s or kan.

Antorior to these forcmina this plate continuo forr.tera to

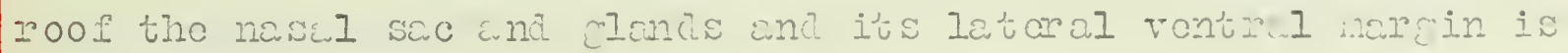

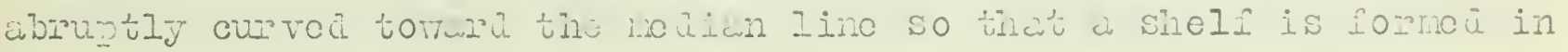
which the caucal parts of Jacodson's ousan lio; whlo the conlralic ond of this orman lios in a small circular formon in the later I Wall of tho cribose. This formon is soparaten from ho crternel narial oponing by a narro bar of curtileve which is not provent in Mriton mero tho tro foramina aro conflucht; but Jacoloson's or gan Deare the scmo rolation to the coop boy in miton as lte loes to the foramon in Dicnictrlus. 

The roof of the antor ior part o: tho cenwlo is intermpted by two oval foramina of which the lateral is tho ortornal narial openine wich extends from abovithe midale nowly to the anterior end of the capule. On the corsci surface, woparated from the naris by a curtiligo bor is a mall gap which marls the bo cinning of the procoss of rosorption of c rtilago woll advancod in e later stago.

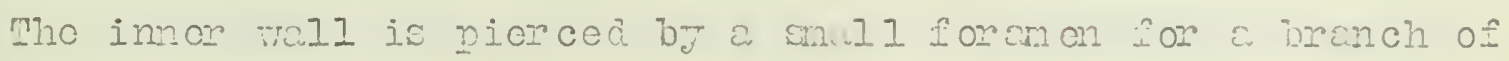
tho suporicialis now which pas os to tho well dofinod intornasal

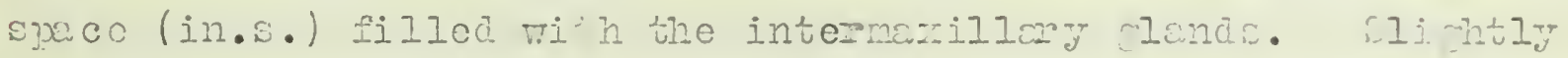
anterior to this foranen is the proncs. I procoss (pn.p.), at tho base of which is the opening for the profuncus nerte as in both stages of rition. The cophalic partu of the cpsulo (c.) is raultod

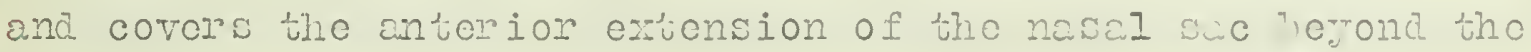
narial openine.

In contrast to c.Il otnes animals atudiod Diomictulus has no

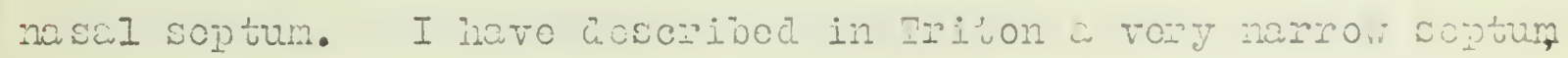
nasi uniting tho dorstl mrenin of the cupsules, just antorior to the olfactory formon. rhis structure is wosont in Diemictulus so that thero is no roof for the intarnasel space on for the anostra

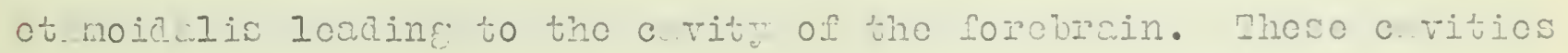
aro continuous so that the intermarillar finds on end bact

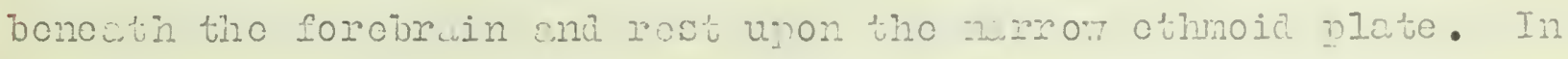
conirast to rriton the forobrain of Dienictulus ex cnds antoriorly berone the ethroil plate as fur as we coplolic limit of the olfuctory toramen and otorlus the internazillany glands.

The wdult whors no furthor cho drificsion of survetures then those prosont in ho carlien lerva (fic. 15.). Jssific tion 



\section{8}

haw talan place in uII parts and further rosorption has increased the size of gaps prescht in the carlier stace. ․ sincle orbitonasal foramon (f.o.n.) oxists betreon the antorbital procos: and the lamina cribosa through which the nesalis cxtornus ant intornus

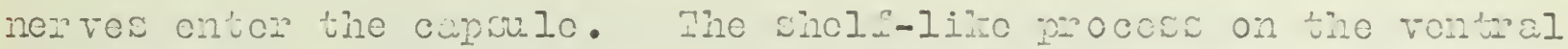
surface of the capar lo has incroasod in sizc and has catondod caudalIy as a short process supporting the postorion limit of Jacobson's or fan. The onterior ond of the or kan extends into the foramon as

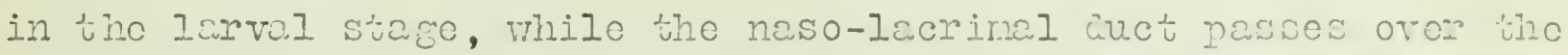
bar soparating this foramon from tho narial orenine, to emptr into the nassi sse.

interiorly, the gap in the roof of the cupsulo he incroasca so that the entire dorsal awpet of the masal s c is crposed. It is separated from the oval narial opening by an clongato rod rinich forms the only roof of the capsule in this recion. Antorionly the vaulted ond is picrecd by three smell formina for the exit of branches of the ophthalmic branch of the fifth norve.

The same rolations criat in this stage botroon tho intornest

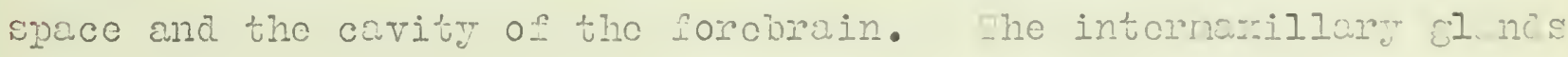
reach to the namorr othmoid pleto, but extond cophalad onle to the antorior masin of the large chocncl onening, whilo in the lute the reached to the pronssal mrocoss.

Upon rosomicncos of the nasal capsulos, Triton and icmictylus

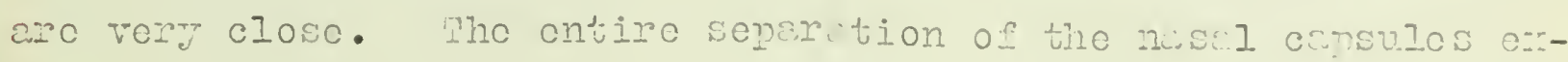

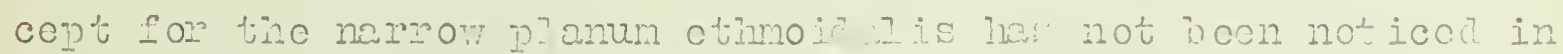
othor Urouclos. he complete connection betrocin the brain carity

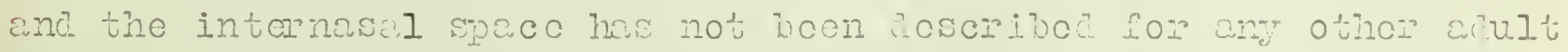
although thore is 3 trensitory con oetion botweon theso mowons in 



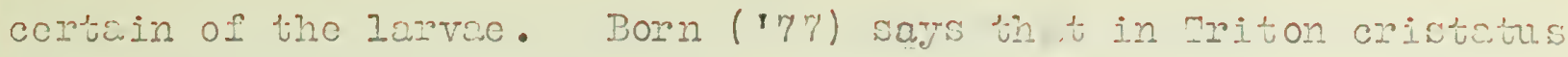
this rolationship persisto throughout lifo cun this fuct pleces Triton and Dicmictylus alono in this rosnect.

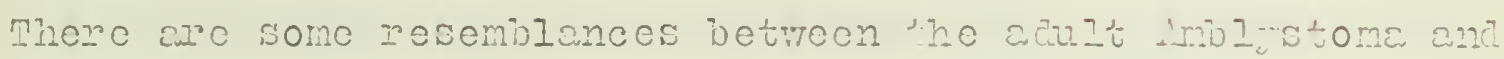
Dicnictylus. The relation on the orm of Jacobson to the formon associated with it and the bar of crtiluge soparatinc it from the

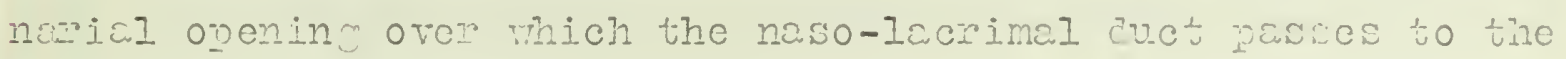
nasul wac, dro aline in both crimals. Ibrthomore the riaconal bar of crtilare uniting the cunterion marin of the cribosa to the

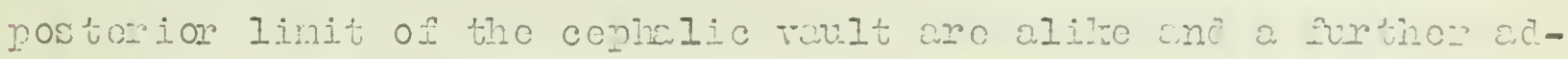
vance in the resorption of cursilioro in Diemictrlus roulc rosult

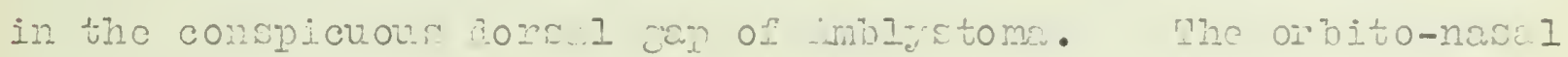

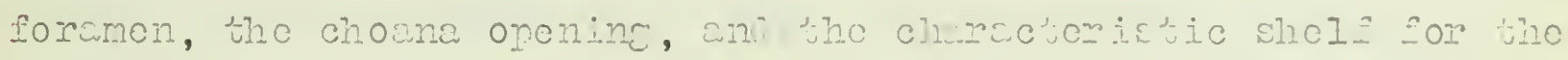

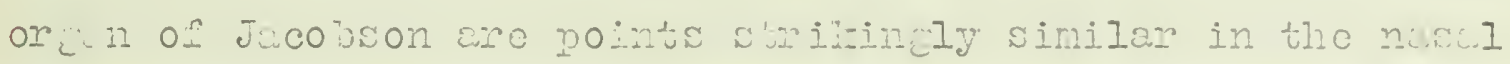
capsules of these animals. On the othom hine the comlote chence of a nesul septurn, the roducod othinoid plato, wh the com leto

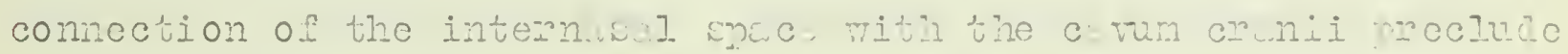
the determination of closo relationsing horo. 



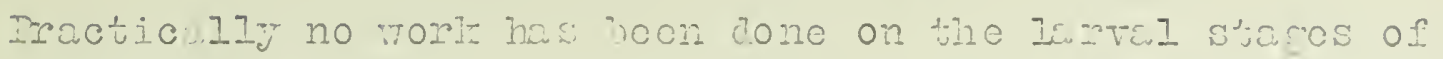

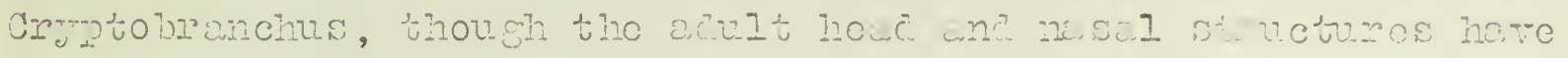

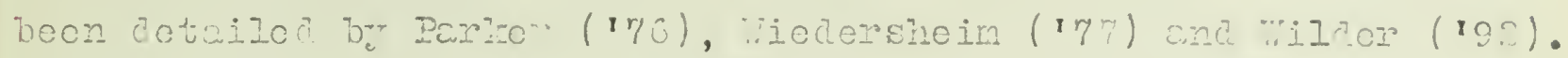

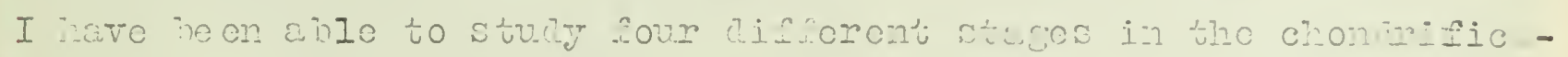

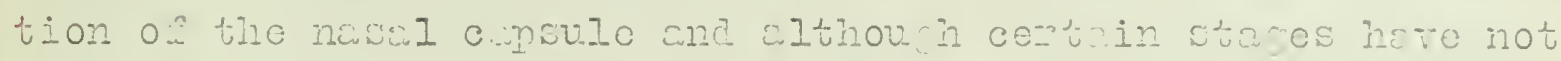

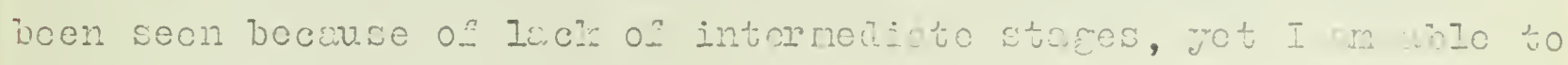

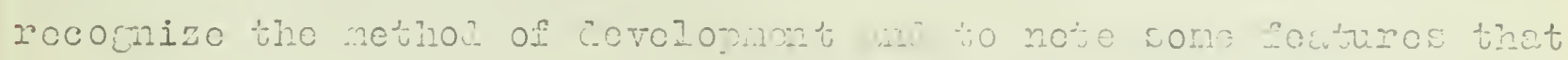
may proove intorestin fron a phylogonotic noin. of viot.

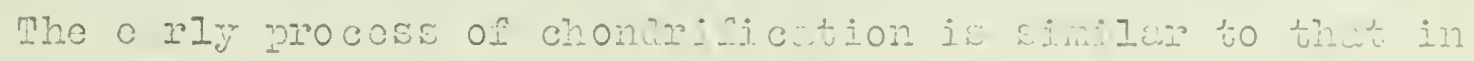

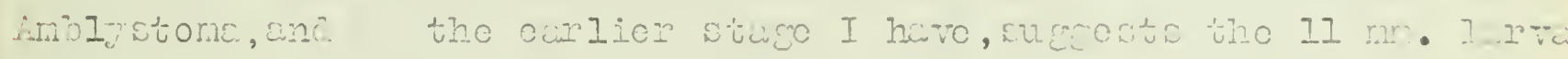

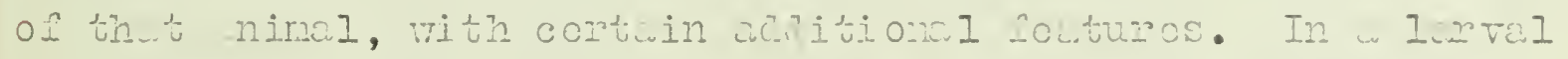

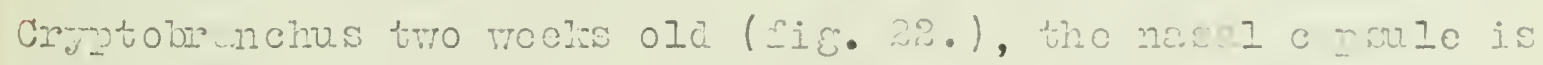
incomicue. In the optic rogion tinc cristo trabanlac is vory

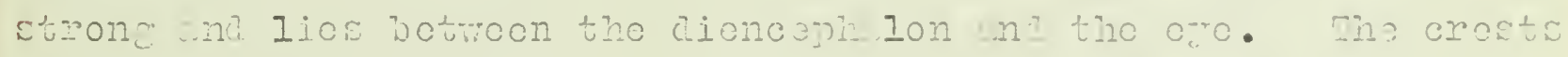

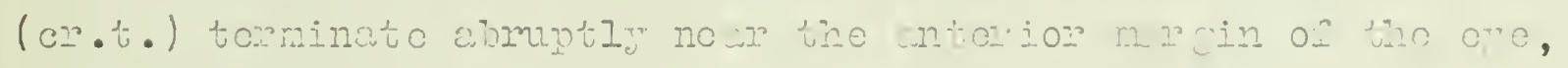

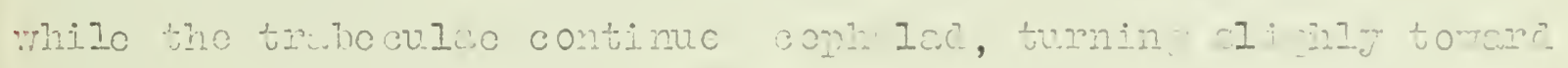

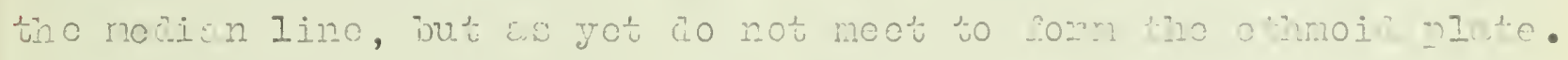

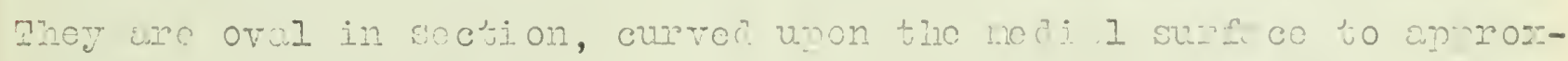

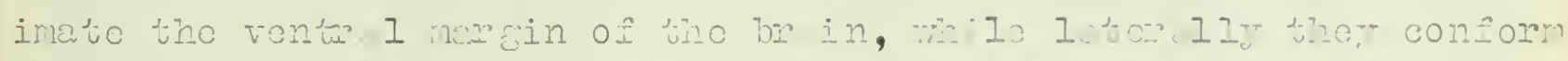

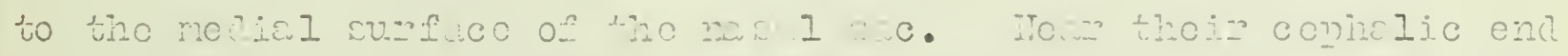

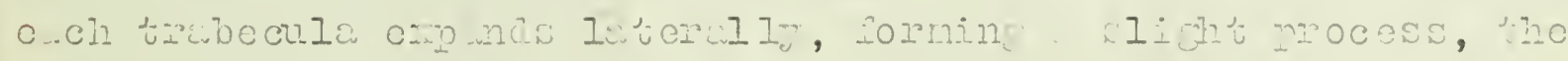

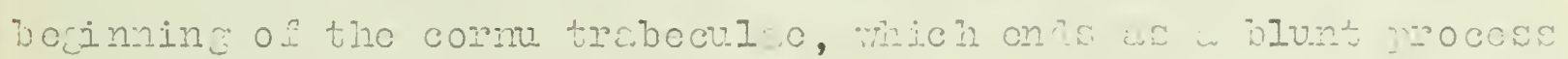
in the enveroping tisuce.

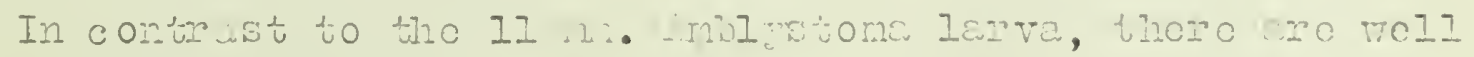

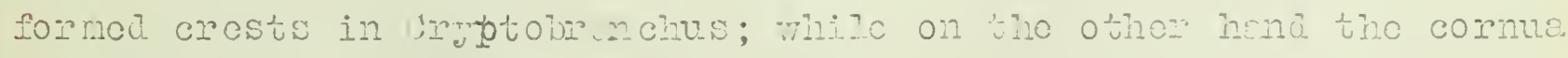

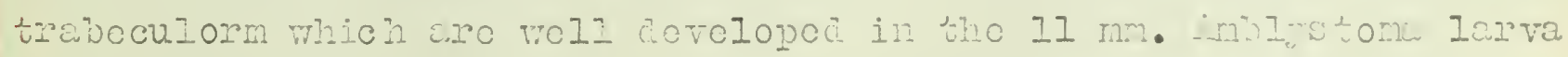

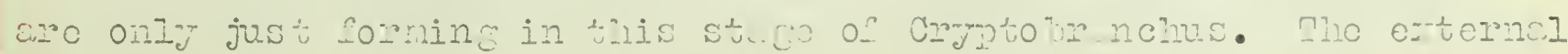





\section{1}

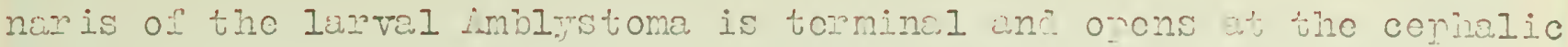
che of the nasal or fan mich is closely associcted mith the cuprule;

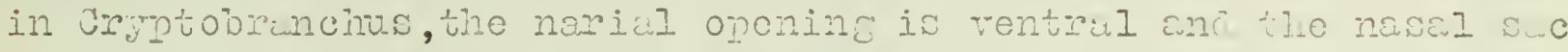
artends bohind the nariel opening and the wtorior ond of the trabecula. An antorbital nrocesis is not pormoi, nor is thore and ovidonce of the soparate chondrifiation of an ethmoitul colum as in the c.rity stiuge of imo I stoma.

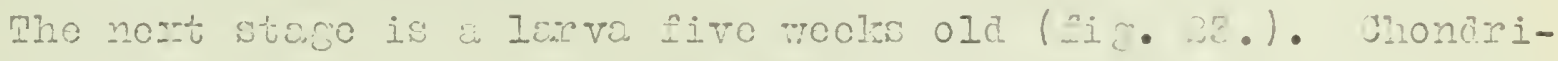

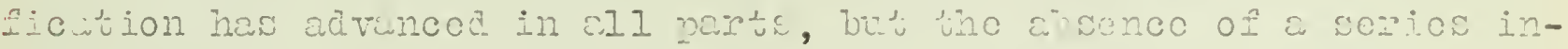

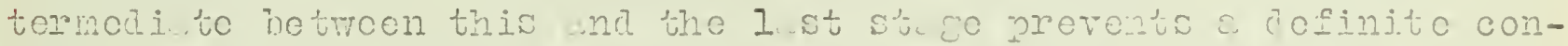

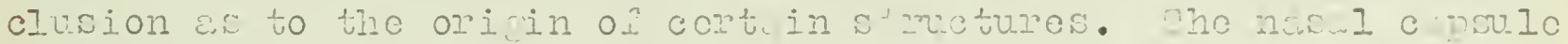

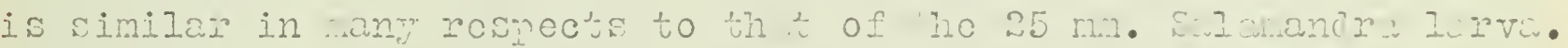
Who columna othmoidilis iscencs sron tho noil I merein of tho tr -

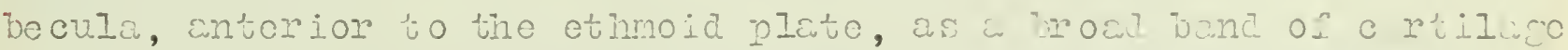
which sopurwos bho masc sce from the internaral an co (in.:.).

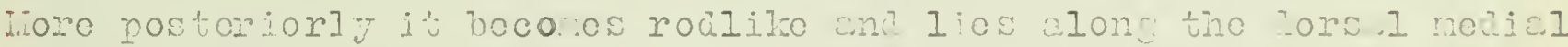

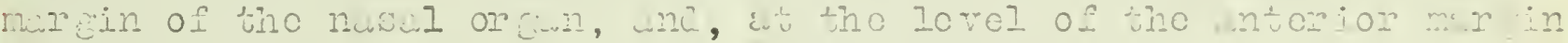

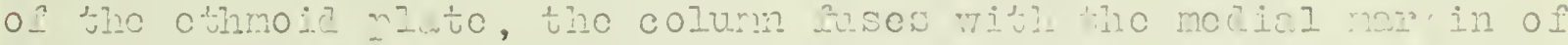
the larec rhomoidal lwnin cribose thich curves otor the c uni

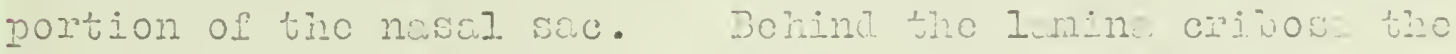

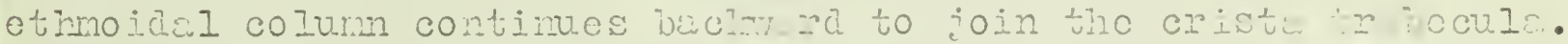

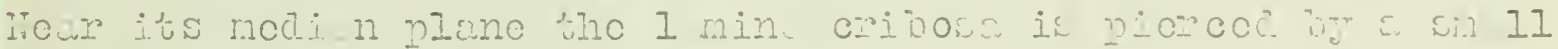

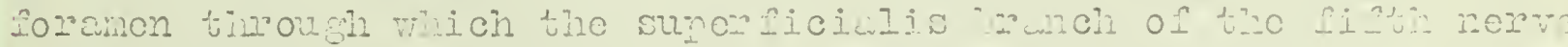

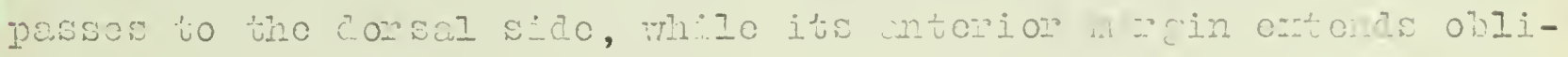

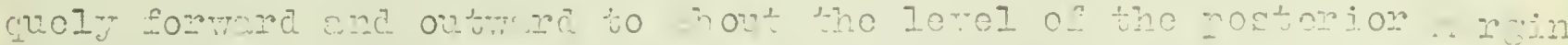

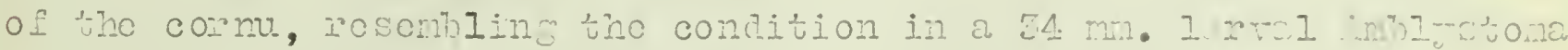

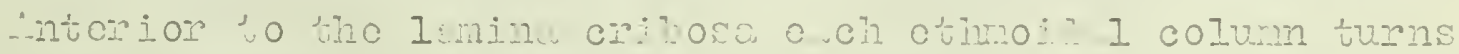

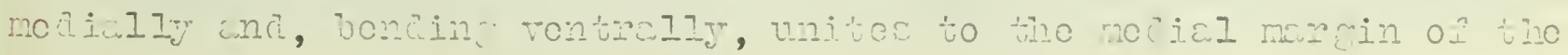





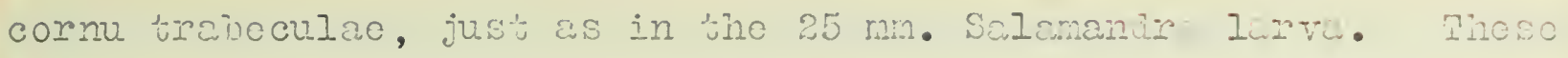

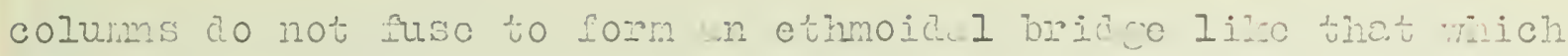

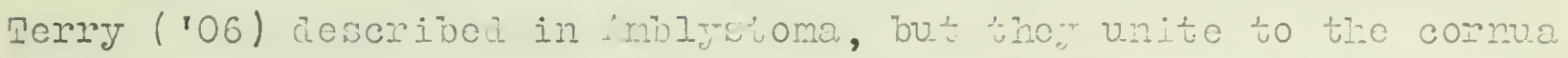

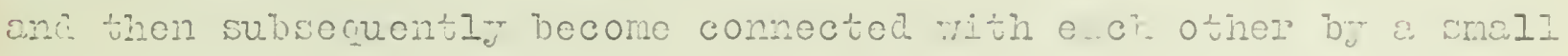

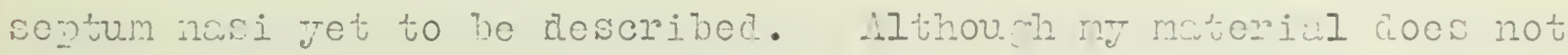
shon the nethoc. of origin of the dimoid I columms, for roasone to be eiven later, I an inclined to believo the those columa

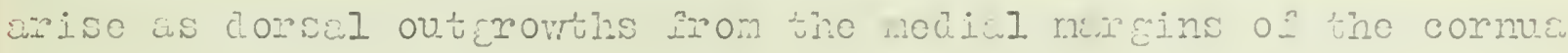

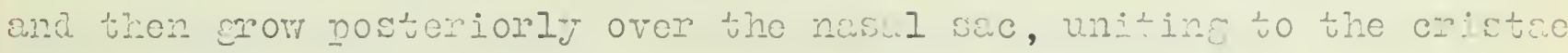

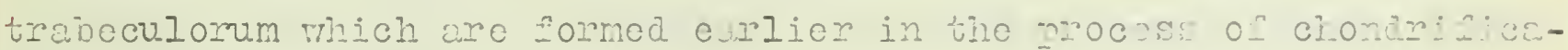

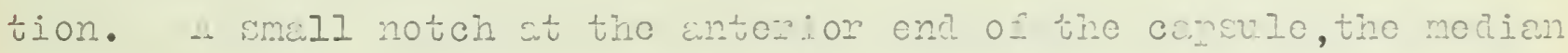

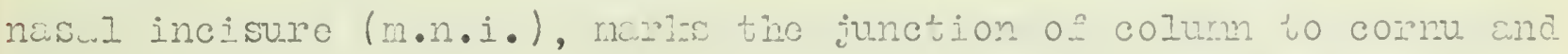

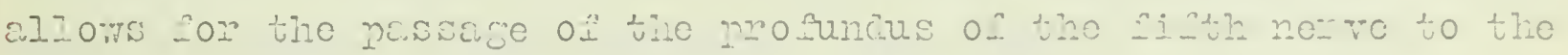
intornasal wace.

From its junction with tho crista, cach trabecula inclinos

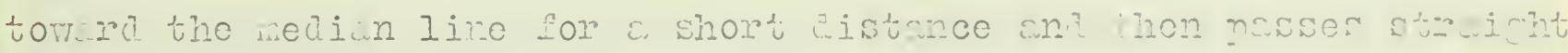

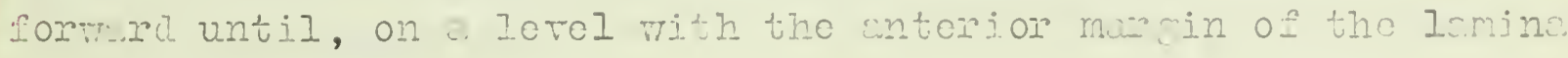
cribosci, the two fuse to form an cumo: plate $(\% \cdot 0$.$) . This$

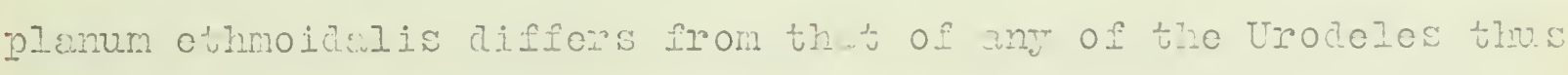

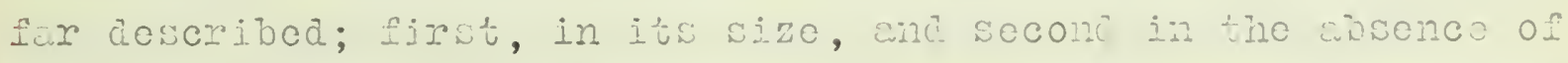

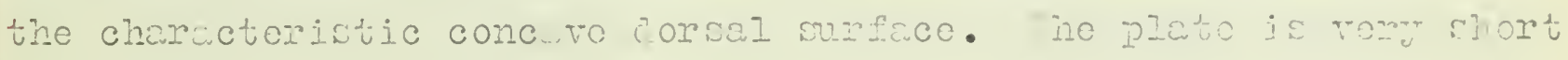

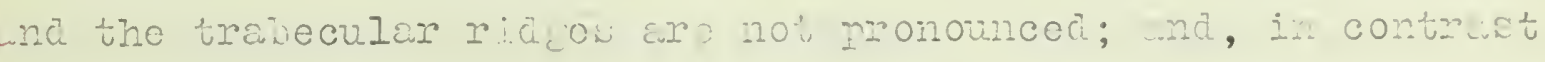
to the other e psules, the dors. I surfice, altioush level at ite

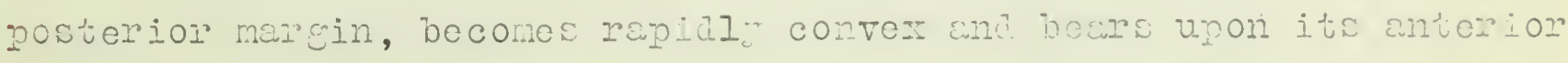

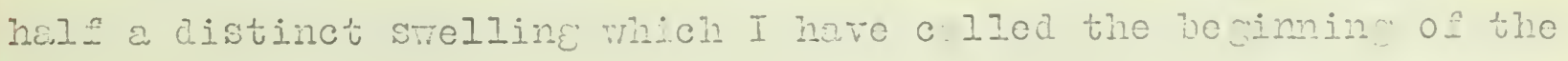

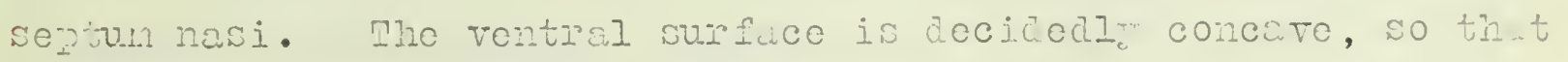

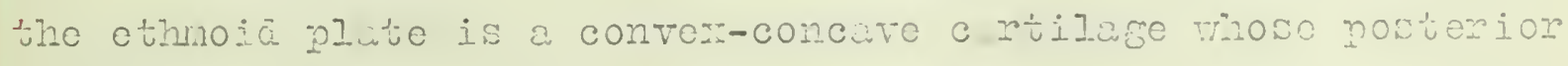

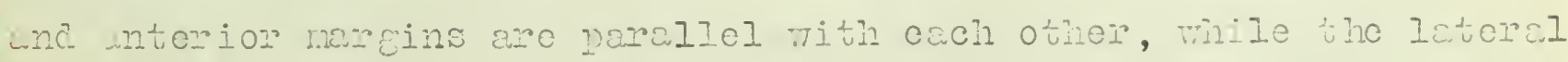





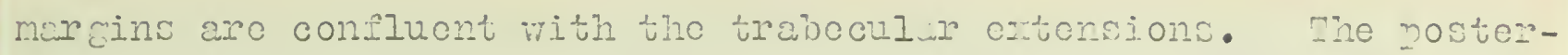
ior morein possossos a short ccudal procoss similar to that of the $25 \mathrm{mrn}$. Salamandra larvo.

i Iargo oval fenestra, bounded postoriorly by the crista trabecula, dors.lly by the othmoidalia and vontmally by the trabecula, allows the pesscere of the olfactory nerve to the nasi l orean. The fore-brain ortencs slightly boyond the septurn, so that viro-thinex of the olfactory sac is latcral to the brain. The nericl openine is tomminal, but is still rontral and consironang antonion to tho capsular structuros. In contrast to the brocd curved plato of boun Ambljotoma and alamandra, the cornu trabeculae of Cruptobranchus is roduced to a harrow curved bor which oxtonds from the cophalic

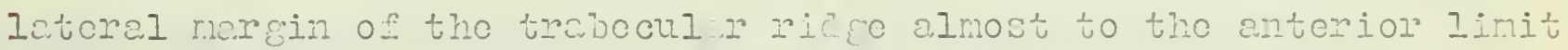
of the cribosa to mich it susos in a lator stage.

Prom the rentral narsin of the crista trabeculco, just nostonior to the laree olfactory foramen, a sondor procose pewsos latorally a distanco equal to tho wictin of tho trabocula ant then bon's ebrupty and outends becincira to tho quedrate. The morpholocienl rolations of this bar, which mat be rocosniecd an do proverd, will de discussod in a lator stugo, mish I huto sicuroe.

A lonva tro nonths old shows iut a vent ali ght advanco in the chondrification of the nasul condule. The othmoia plato has incroased in size and has lost tho hindor process of the carlicr stesco

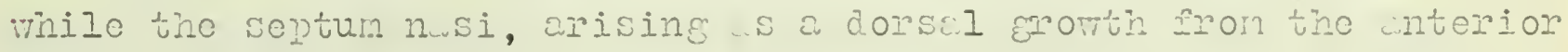
part of tho cthnoid plate, has enlareci and has decono continuous upon its lateral antorior angles with the rontral noretins of tho cophalic extonsions of the etrmoicil colume.

$\therefore$ Jot there is 110 medion nasal process, so the ontire dorsal 



\section{1}

surface of the cophalic portion of the nawl sac is crposed. The antorior angulor procoss of the lanina cribosa and the latoral narEin of the cornu nore closely approzimate each other, but as yet there is no cartilage ring around the olfactory orean. The cornu trabeculae and the antorbital process comose the whole sloom on the capsule. Tho antorbital procosscs now extond forwers from the anterior ond of the pterycoid process.

The last stage of Cryptobranchus studied, was a larva threc months old,( 1 ig. DL.) ; chondrification has advencea in all nemts and a botter definea nasul copsule is now prosent. The lamina

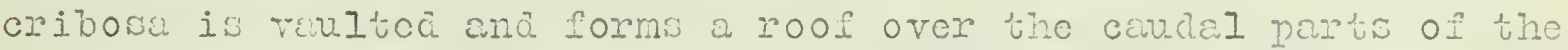
olfactory orean which extonds behind tho chosna, which is lonf and narrow and reaches forward to the lovel of the ethmoic plato. Who

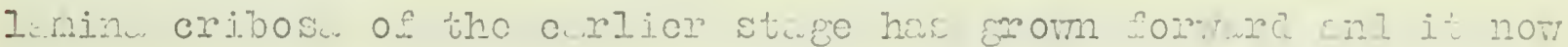
covers the posterion two thimes of the olfectory organ, wh tominates cobruntiy at about one fourtir of the length of tho conculo from tho conterion end.

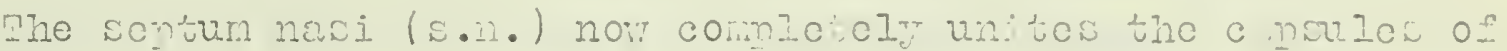

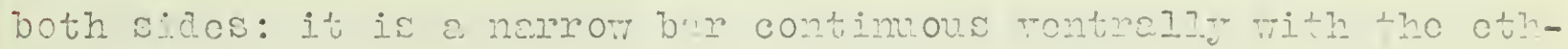
moid plate upon which the olfuctory lowes rest. This sortum

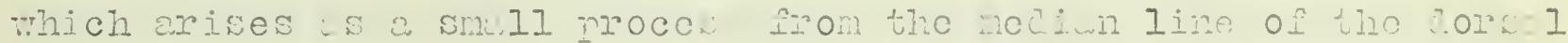

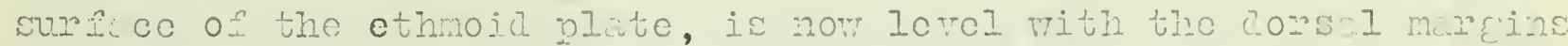

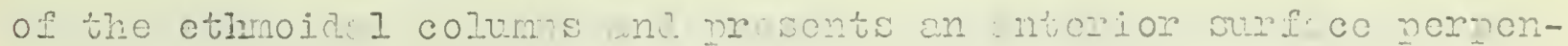
diculin to tho main was. Whe rostorior m rein of the ethuoid

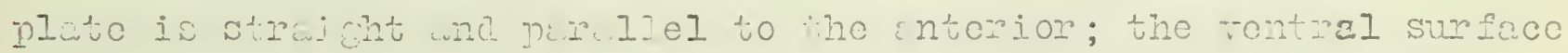
is flet, while the dorsul endes into tino sontum, so thet in

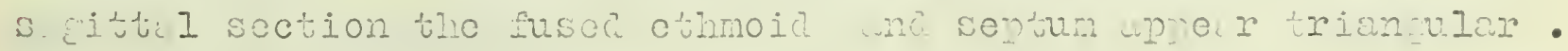
ntortor to the junction of the limincr in tue to the othmoidal 



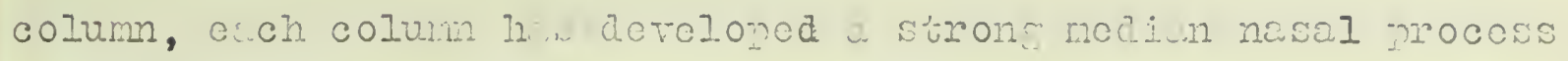

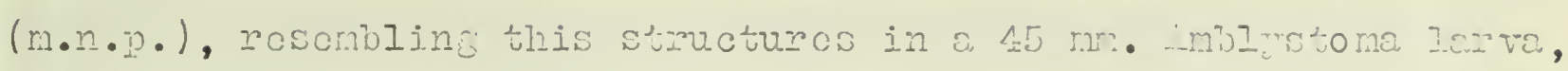
and each is soparated from tix lamina cribose by an elongeto fonostric narina(fen. n.) which is conflucht with tho eatornel newial orening. This procoss forms the roof for tho noaid partes of the nasal sac and tho nasal clunds, as in othen Uroêclos. It is also piercod by a wmall foramen for a branch of tho ophuthalmic sumersic-

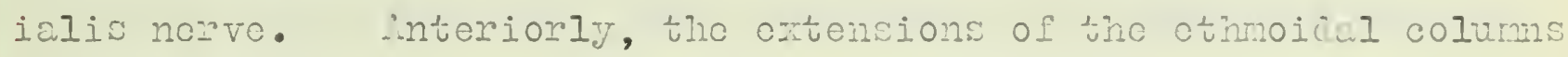
have fusce to tho cephnic limise of the comua, thus forming a

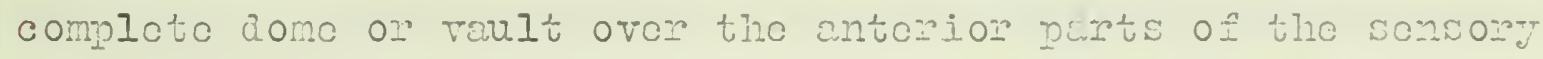

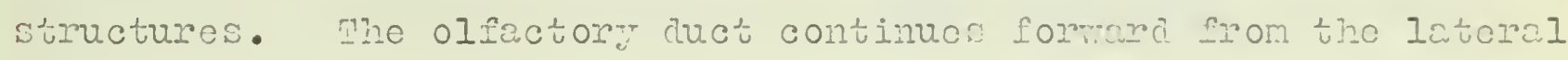
margin of this dome and opons through whe extomma naris antorior to all capsulai stmeturos. mhe medial toll of tho curola is piercod be tro foramine for the rami profundus and suncricielis of the fifth norvo. Intcrmazillary ul mis do not ocovin in tisis anime1.

Ihe cornu traboculac of cach side curros bachara anc unites distally to the antorion linits of the lamina cribosa, so uhat now ¿ comploto ring of certilage is actolonod around tiro nascl or can. ilthough as yot rery small, the orgin of tacobson rests uron the cardal crtension of the comm borond its innction with the lomina cribosa. I heve not observed the naso-lacimal tuct. and ís rolation to this bar in Cryptouranclus. Nhe comlulic crtension of tne antoritital process his incrocsed, but no connection Dourech it

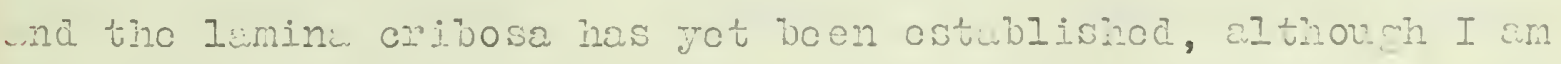

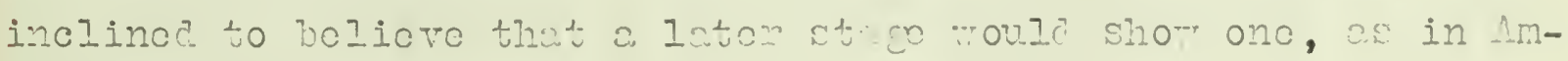
bIy stome and Silamendira.

This bus of c ruilare, nentioned in comoction with the five 



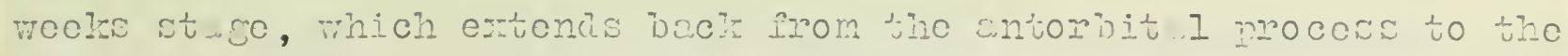
quadrute, is undoubtody the ptorycoid which doow not crist, so fur w I lnow, in wich comlete form, in wy Urocole with the wingle

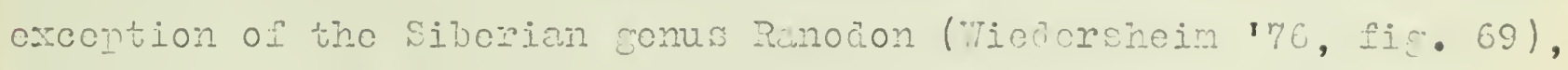
althour the junction of the bar vith the anterior recion of the craniur is the normal condition in the invir. This condition timons sone ligin unon the naturo of tho antorbital process in the Urodolos. Sone Jeure aro Geupn questionod a stutemont by ringsley (192, p. 672), who saia:"tho lower procoss mu rotain the n no, sntorbital, usuly aroliod to it, for mhiume prosonts no otironco

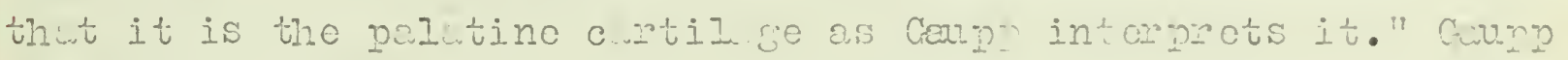
(193, foot-note p.430) says: "Hicru nochte ich Donerisen, dass ich die beiden Iamen "Antoroital-forsatz" und"Cartilaco palatina"

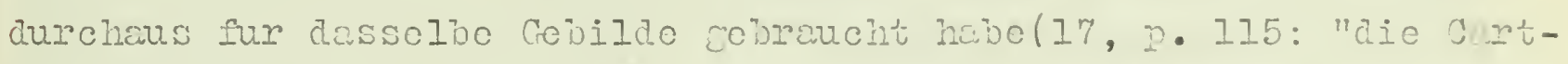

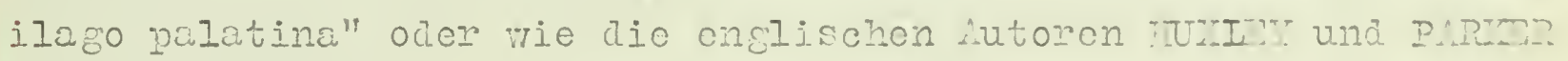
(ien Inorpel nomen, ion "Processus antorbitalis"). Is "procosus

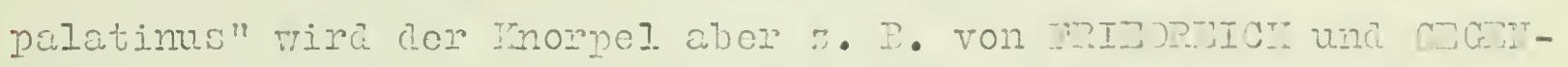

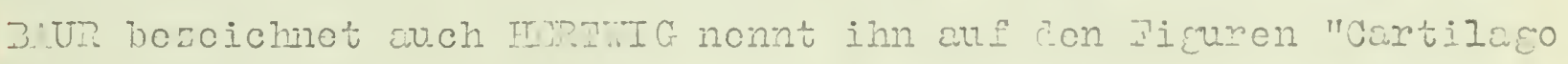
palatina", und "ichershoim anricht ron einor mtorbitaliortactz odor "Gumenfortsatz" dor doủschen tutoren. Da ich beice Bezoichmungen in dor Litoucitur vorfand, so errohnte ich sio auch boide, have abor nicht oura e nom bezannton Goildo oino neu Joutung goben wollon. "IIGIJI scheint untor "Palatine catilano" hior otras Bosoncieres un verstehen; ras das ist, lrani ich cus soinen Lngaben nicht orsehon". Winslom ('gs) discussod tho question and concluder that until it was shom that the procoss in trocelos

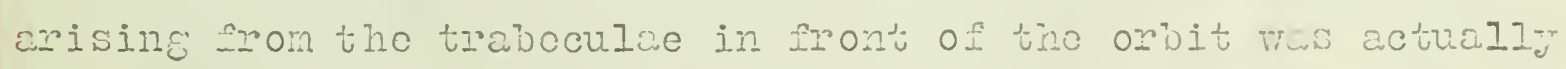
purt of the pterygoduculrate, the name antorbital shoula be continued 



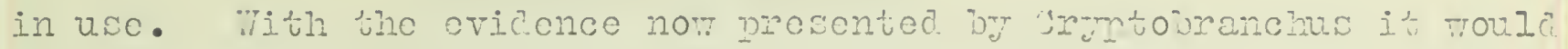
scon as if the bankl nart of the process in ell trocolos is really an antcrior portion of the pteryocuacrate. Jut the ansorior prolonfation of the procoss is somothing adcitioncl and camnot de

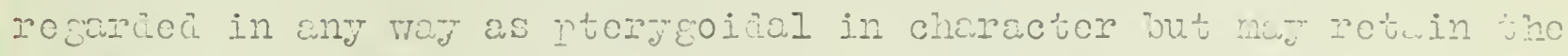

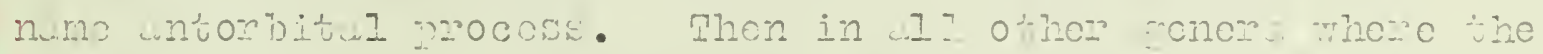

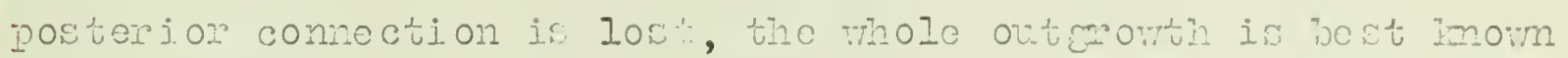

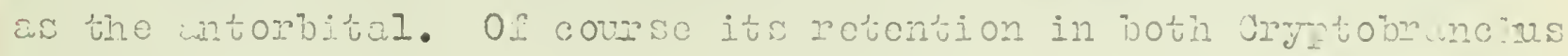

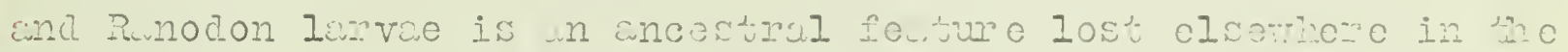
Urocicles. In the adrut of both tho fmoricin and Japanose apecios

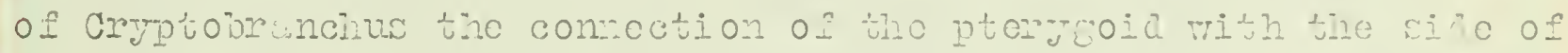

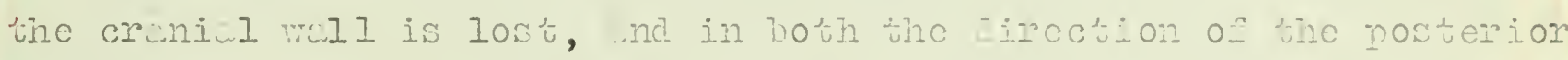

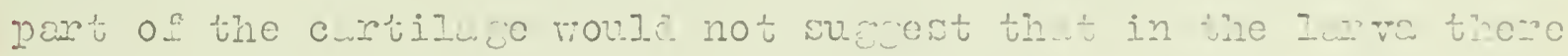
Wus any weh concetion with the trubecula or nu rolduton with a pulesine bone.

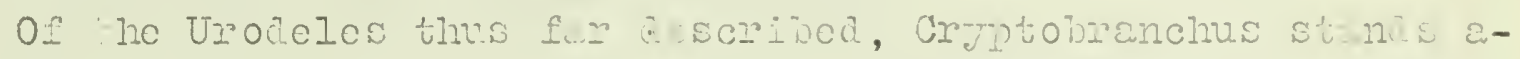
lone in tho oricin of the sonterm nasi. In hoth "milstom" n'

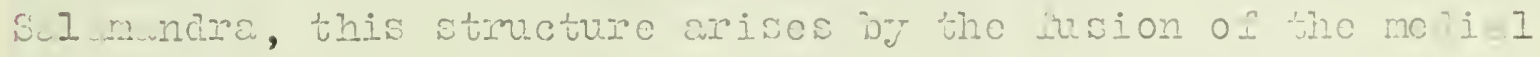
procosses from the copla. lic chis of the colume chnola lis. On

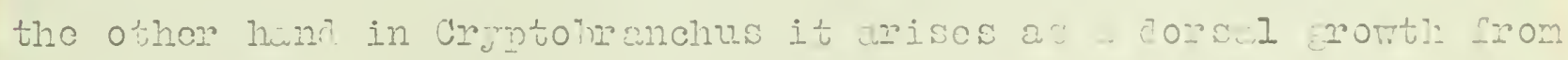

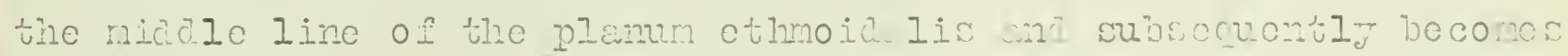
united to the cthnoidul colum. The luter chondrifiction of the

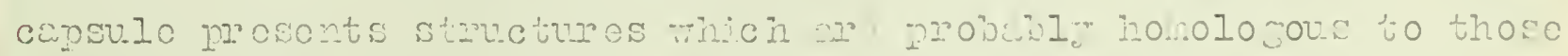

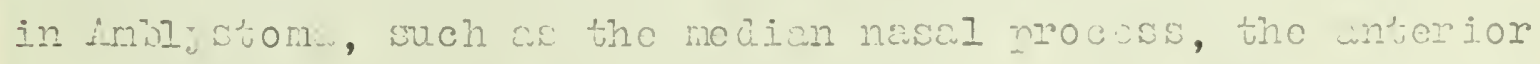

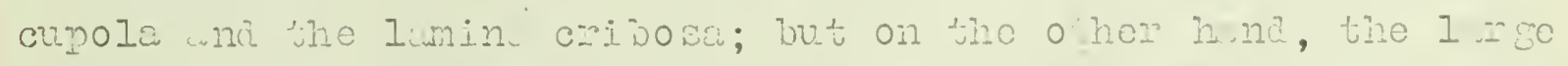

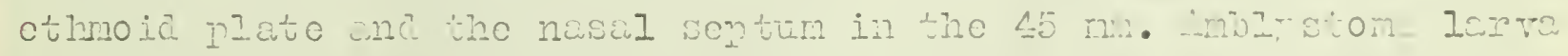

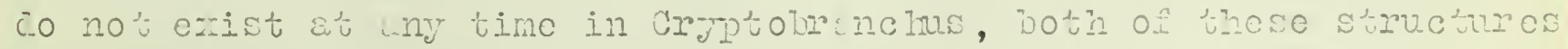
being grecity reduced. 

Spolorpe: bilinestus.

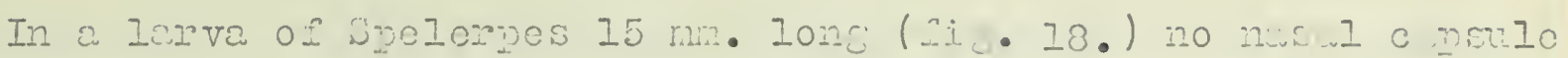

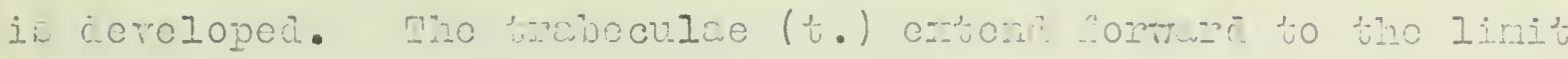

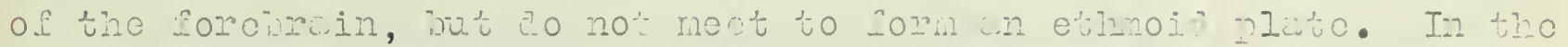

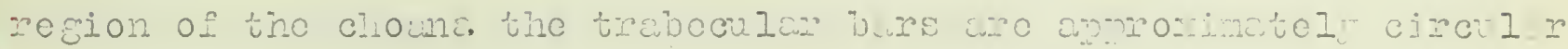

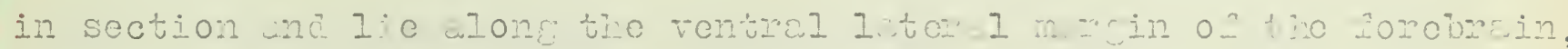

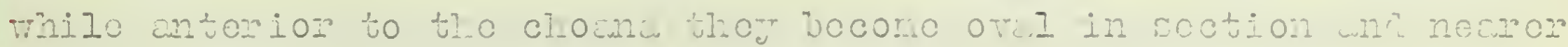

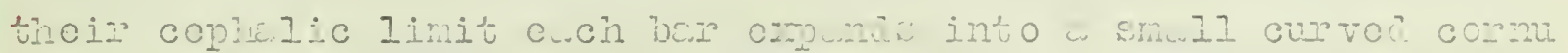

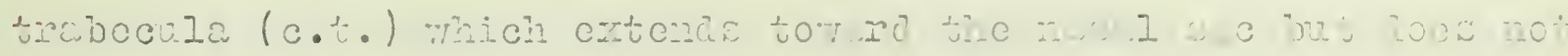
rewch s. ht no time is oither traboula cloco to the nasal sae,

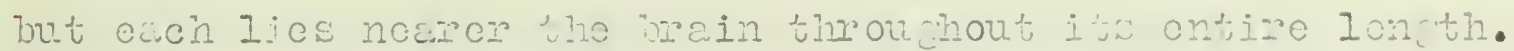

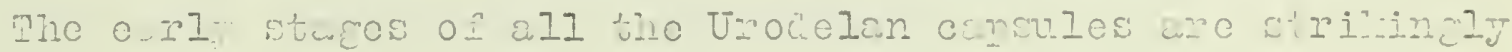

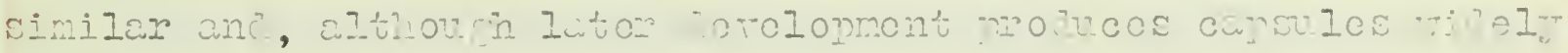

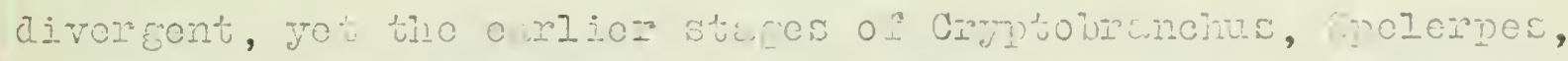

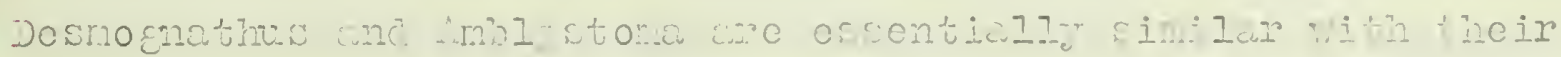
simlo traboculio ane cornual oujonsions.

In $\approx$ I

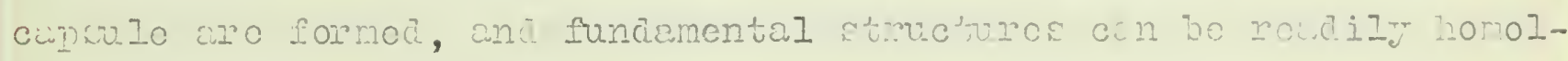

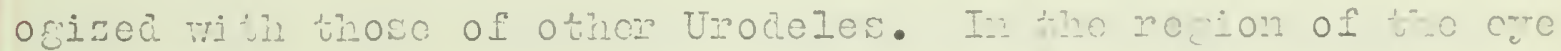

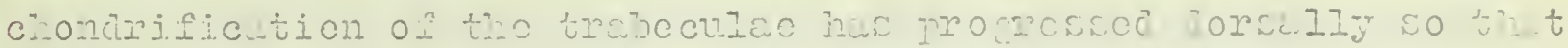

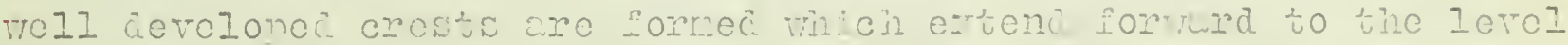

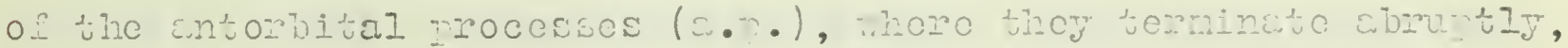

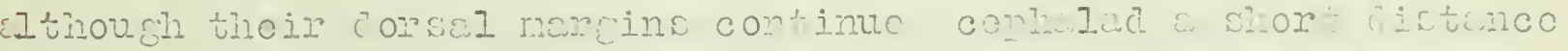

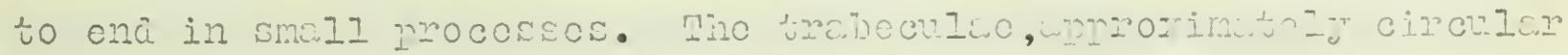

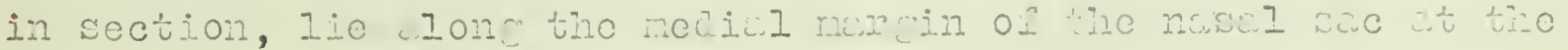

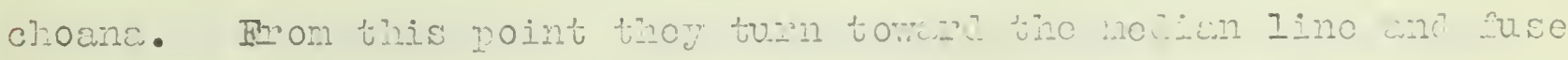

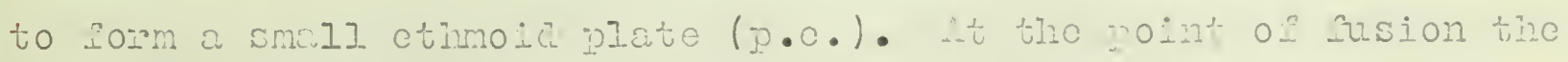

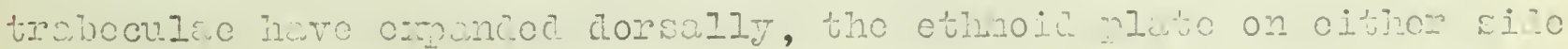





\section{9}

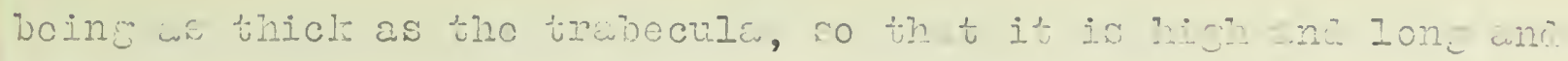
rosomibs that of Crrptobranchus. Dorsal mocosses from the me?t I

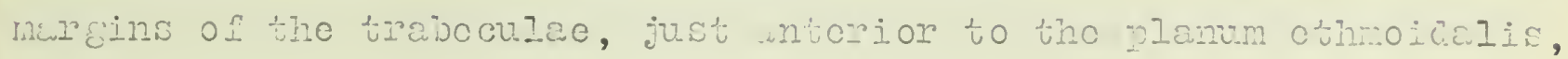

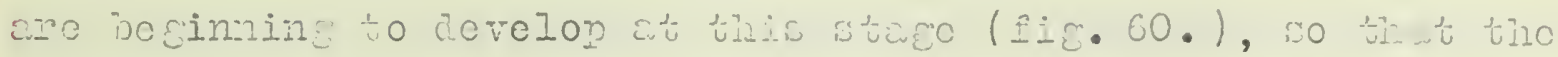
latorel trapocular marein is concavo, fthus formine w woote in

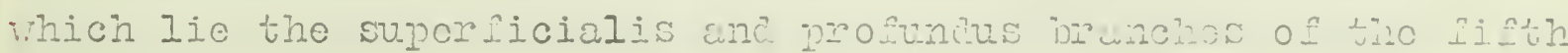

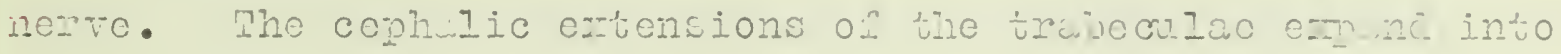

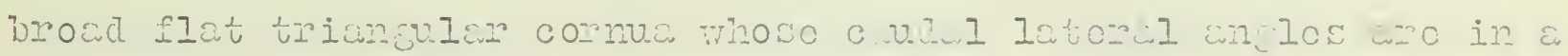

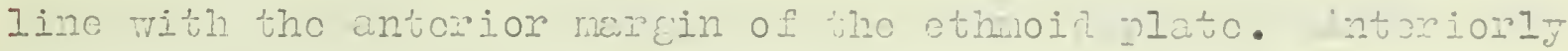
tho artone to tho level of tho extornal nuid ononine wh we sopar: toc from ouch other by doon intra-traboculcr nouch (i.t.n.), es wiclo es tho Ioneth of tho othroiln pate.

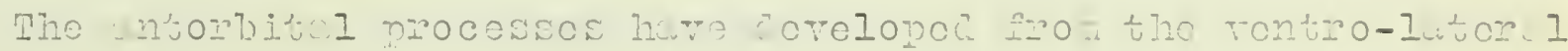

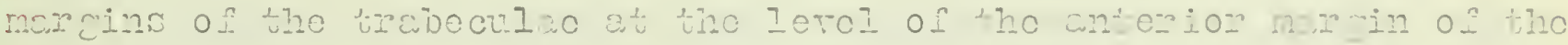

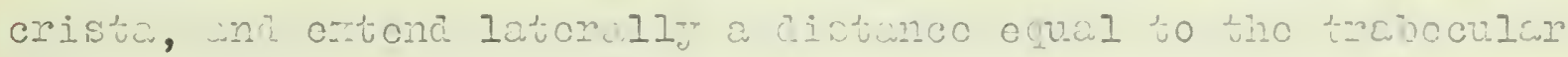

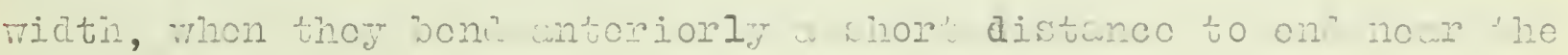
chocinal oponine

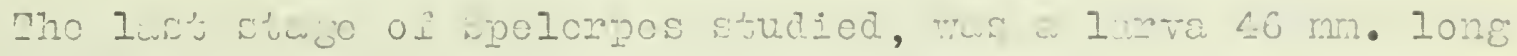

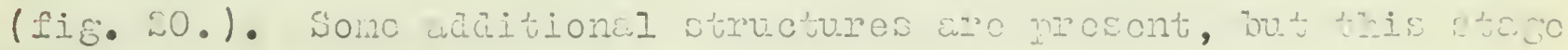
is not sufficionty developed to honologine tho comiote hasal capsule with those of tho othor Unodolos. In tho rection on the

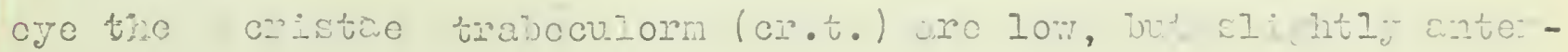

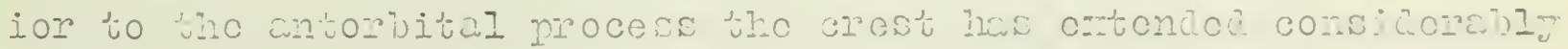

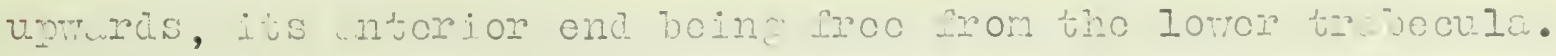

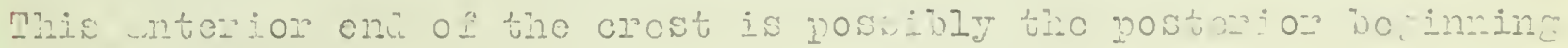

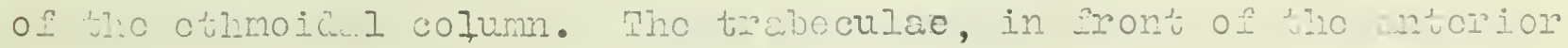

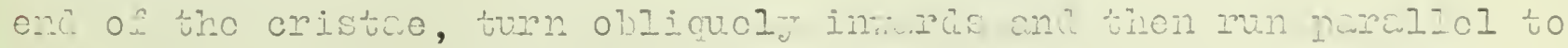

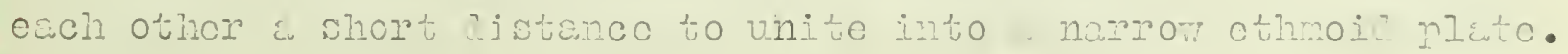



Whe othnoid plate itwols is decicody umalor (throug resontion) than in the carlier stage, both in Giches an in lonoth.

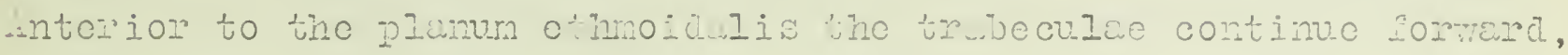
sopar tod from cach other br a narror intra-tzonoculic notch, nde then each, at d voint the with of this oteh antorior to tho othmoid plato, sivos rise to a shall procoss from its dorsun nocici marein

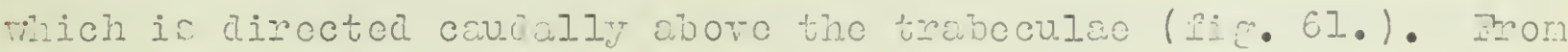
its oricin and rolation to tho trabecula I lolioro tis to be the cinterior portion of the ctrmoiden column. These grocossos rero

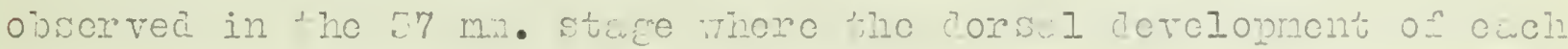
trabecula indicuted the oculy stege of this meinontary colvm.

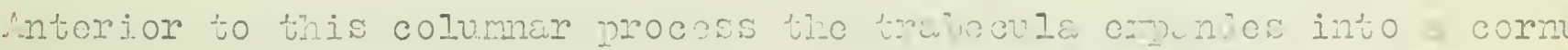
similar to thet in the $37 \mathrm{~mm}$. Etaco.

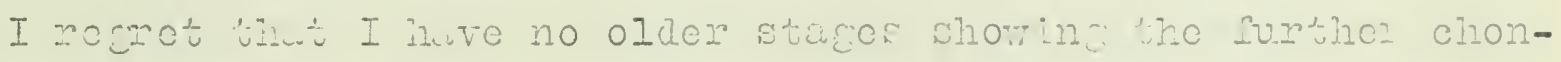

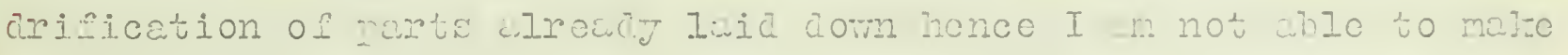

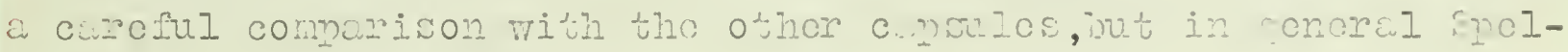
erpos seems to indicato a peturder morth of all nartis. In comer-

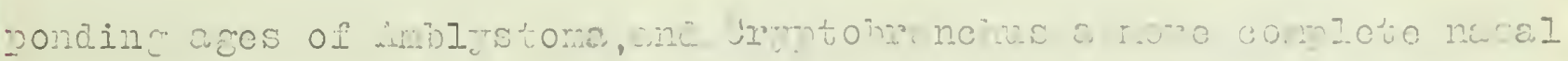

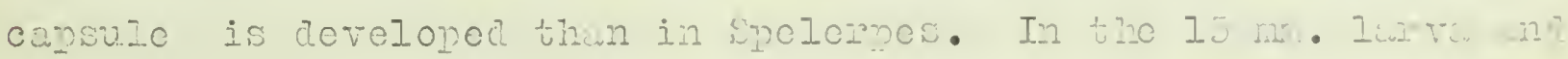

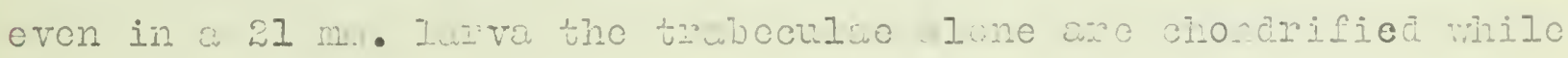

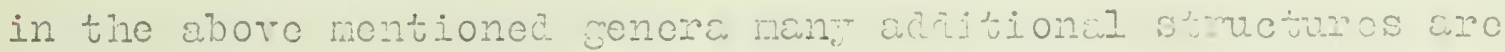

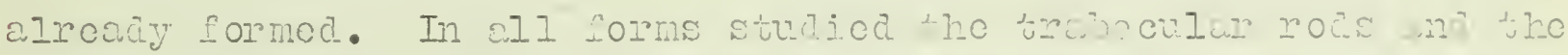

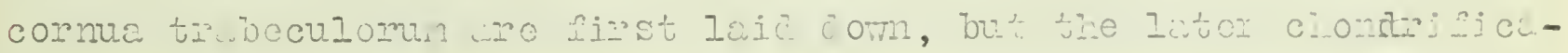

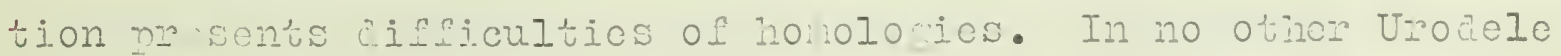

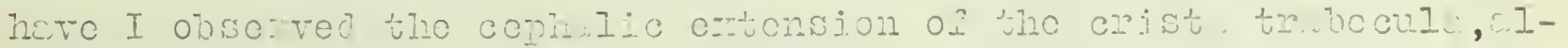

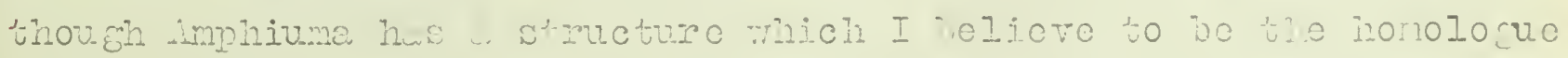
Of tris mocess, chu, juc cine from their relction to tho nus I

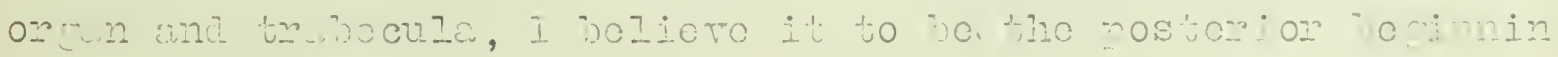





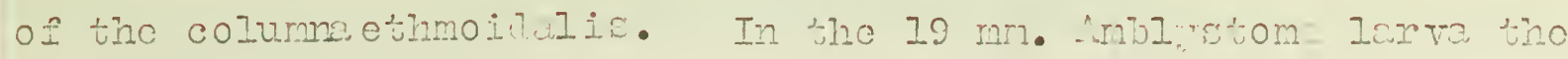

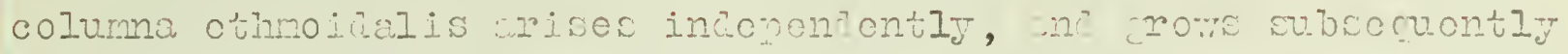

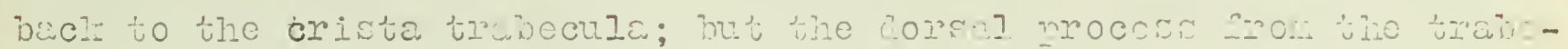

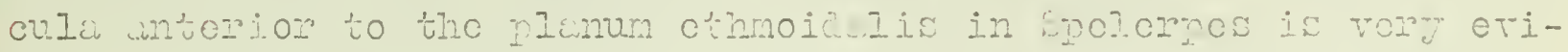

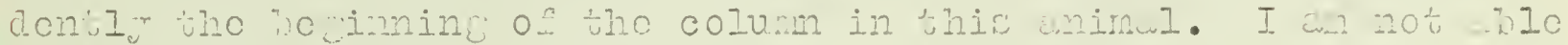

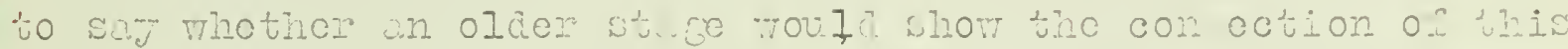

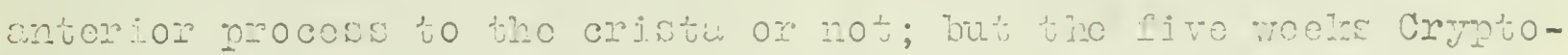

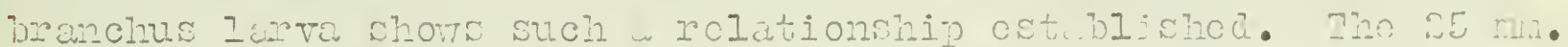

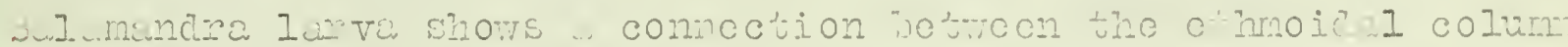

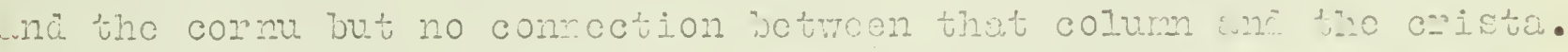

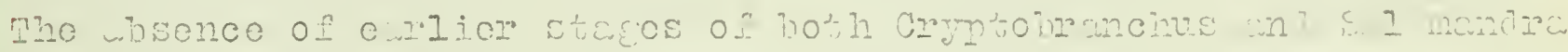
precluke the dotominution of the onigin of those colums so

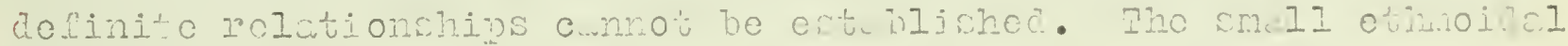

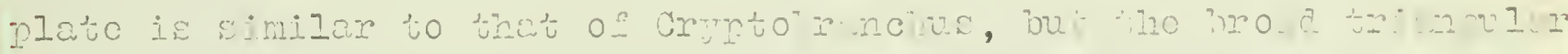

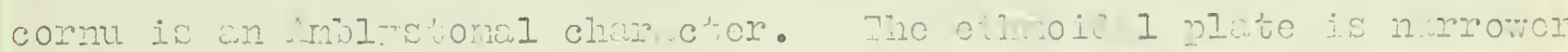
then in the other types, tho rosult of the comut tranin town?

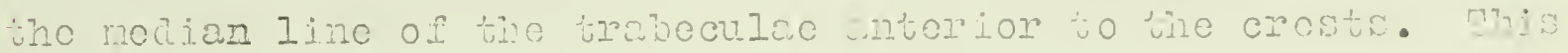

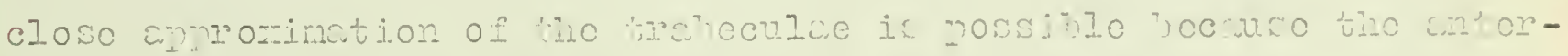

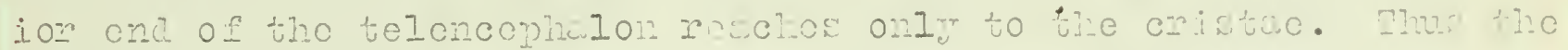

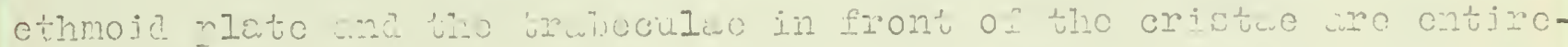
Iy whtorior to the forevrain which ioos ro hold for an of tho

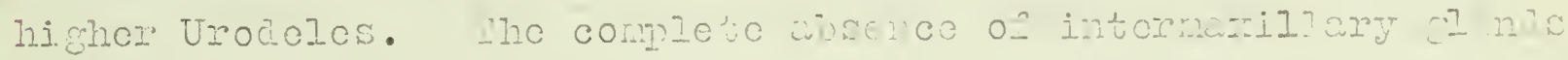

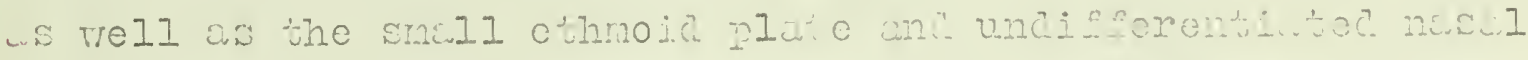

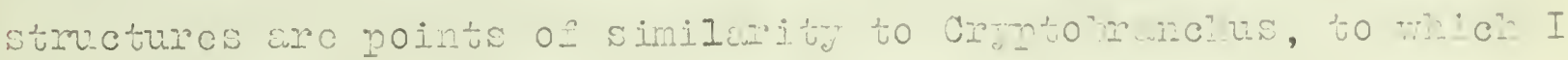
bolicre spolernos is closely related. 

Dlotinocon crythronotus.

Winslow (193) has doscribed tho nasal cansulos of a $20 \mathrm{~mm}$. Insva of Plothodon clutinosus, chi he comperos it to a $45 \mathrm{~mm}$. Am I watoma

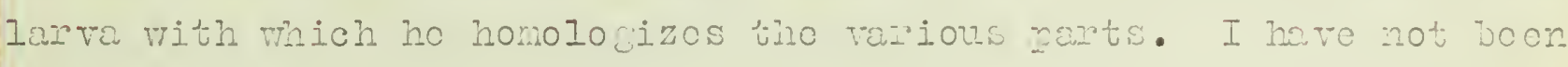
coble to study chy larval form of tho conus, but hate oramined ant

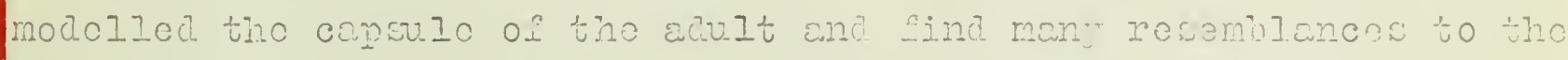

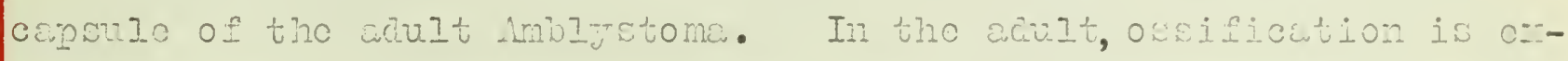

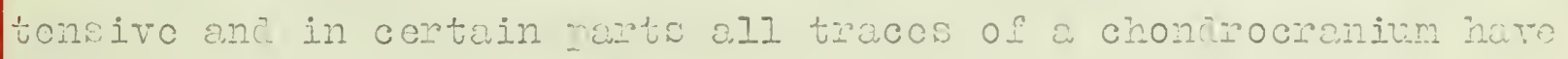
cisappocred. In tlie rocion of the oyo tho trabocular crosts hare Deen lost and tho rosorption mocess has continuod v.p to tho olfector

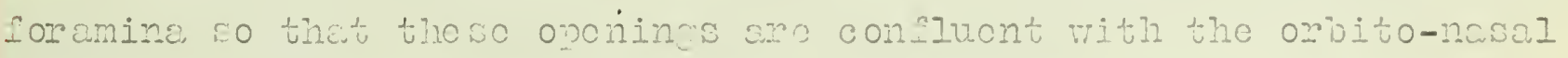

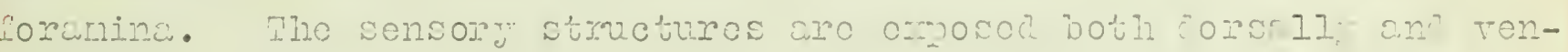

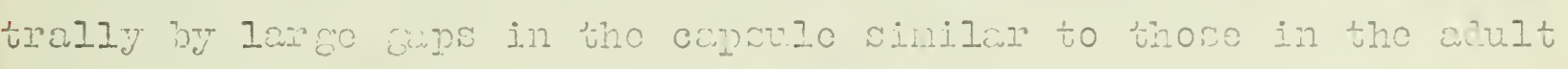

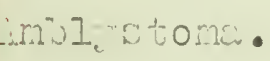

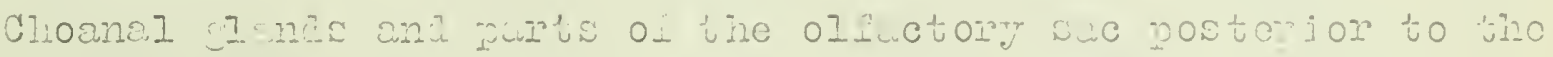

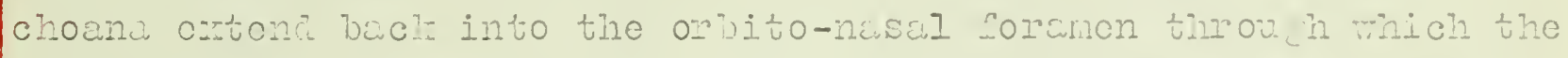

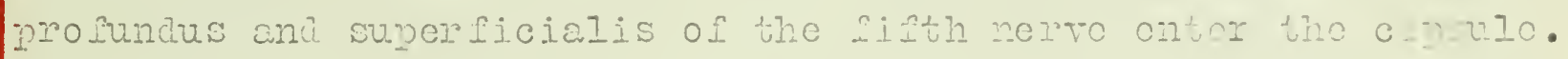

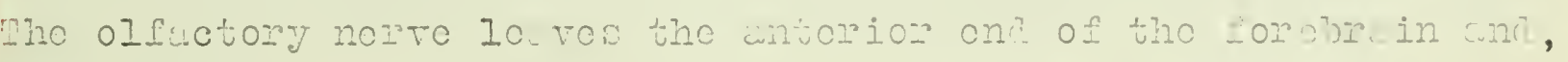

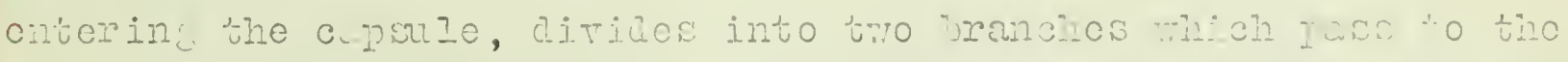

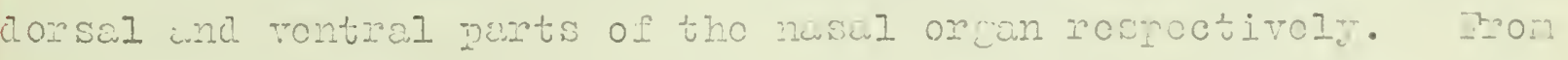

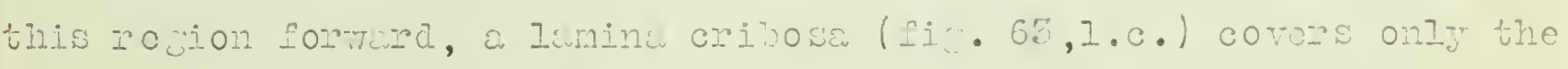

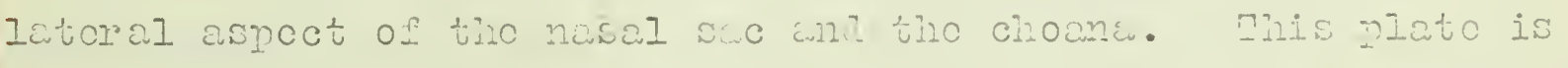

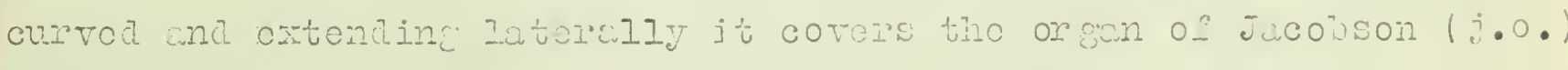

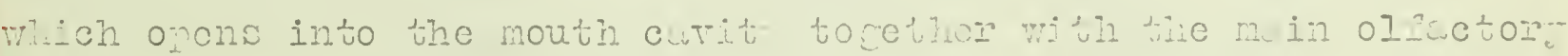

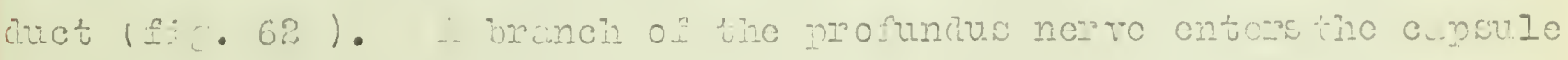
throv. It the omal formen in the criboss ant lies lon the dorsal

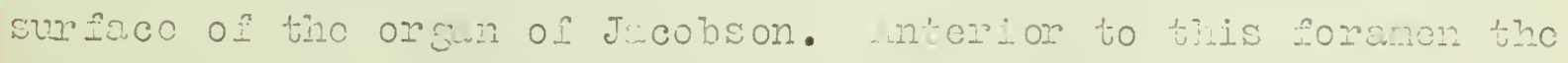

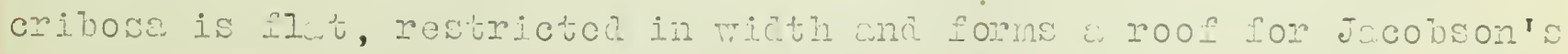



organ only, and is continuous unon its anterior no ili m- lo to tho ceph Iic vault by w dorsel procoss (a.n.), aimilar in every respect

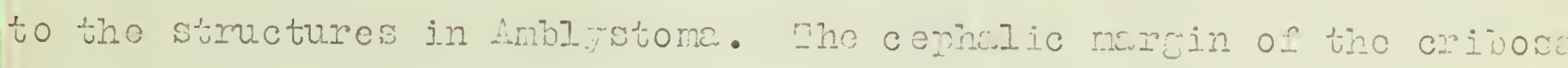
is piowcod by a small foramen through mich the profundus newro pusses from the chpulo to the antorion romion of the snout. Fron its conhalo-lateral and to the critrosa cowinues into the latoral merregin of the cornu tribcoulae which has o:pundod to form tho floor for the ontire antorion vares of tho cupsulo. Tho whonior linit of tho I min cribose is maltod by a sm 11 mocoss which is soporited

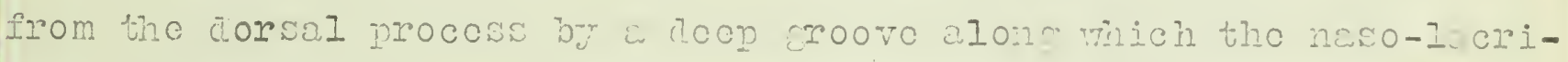
mal duct pasace to cmpty into the nasel organ.

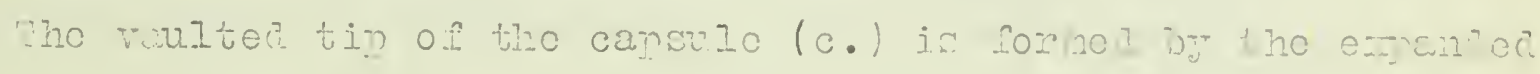

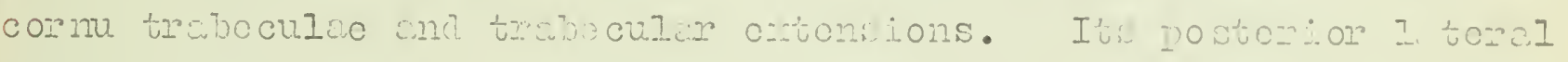

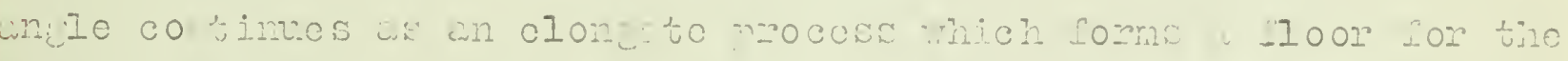

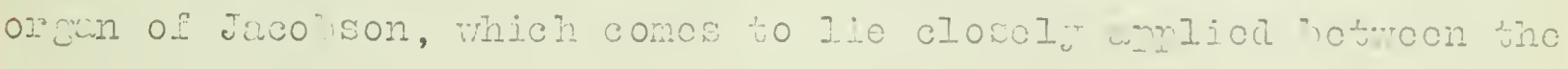

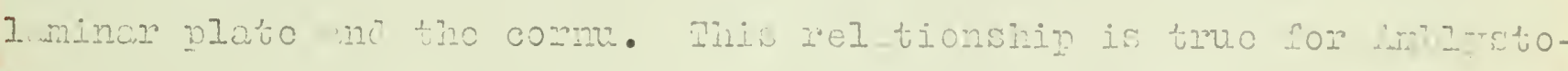

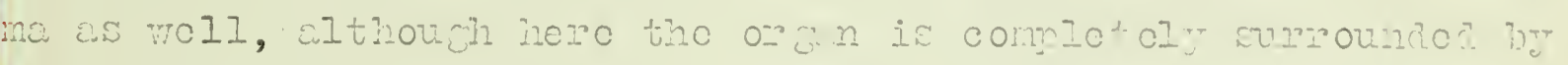
c.rotilago.

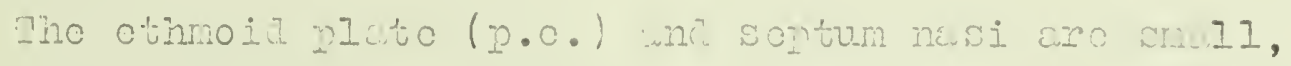

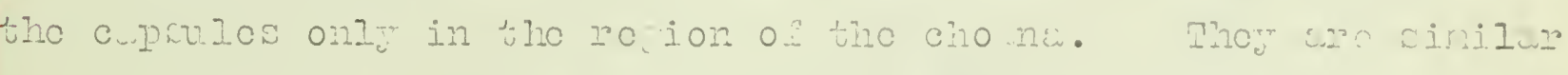

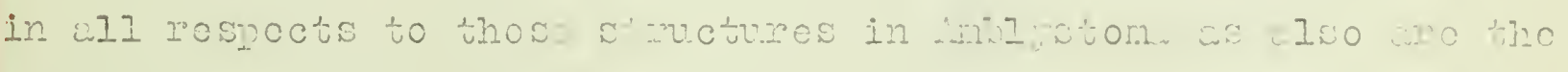

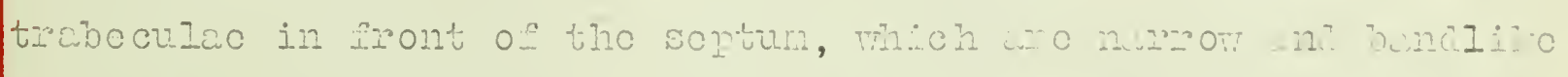

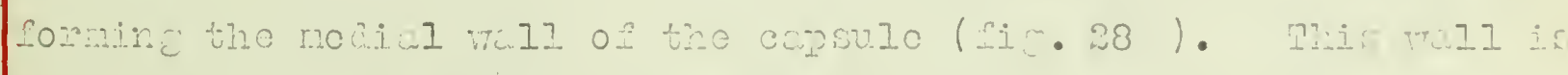

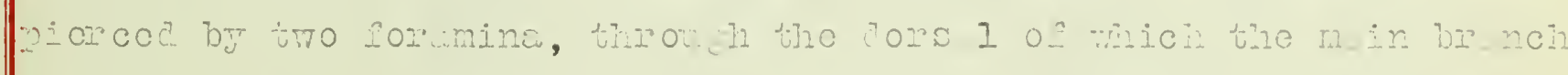

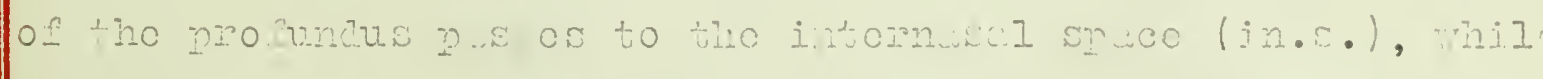

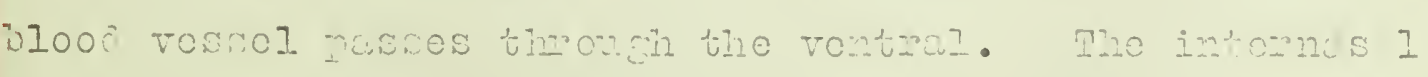

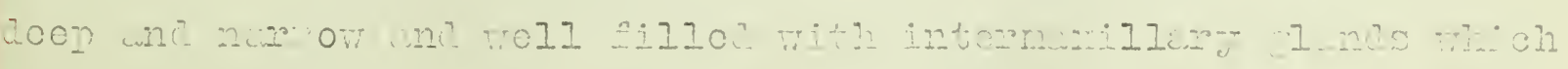

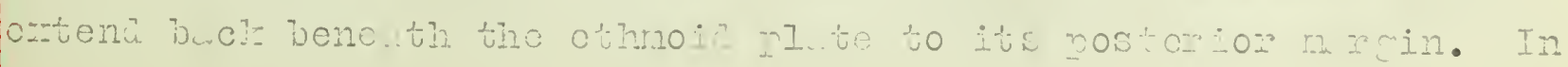





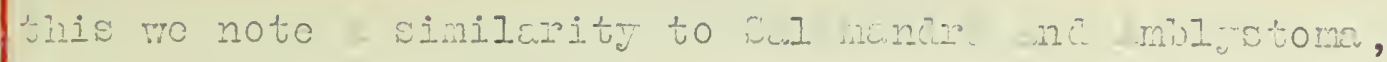
$\because 011 \ldots$

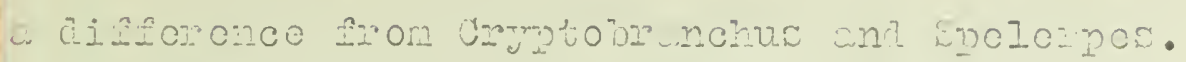

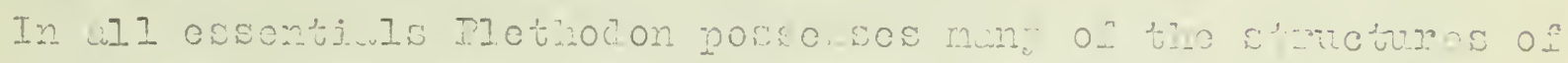

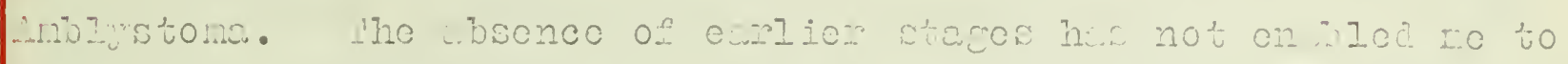

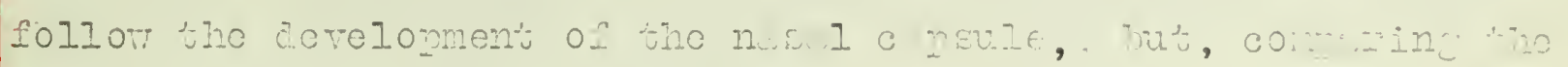

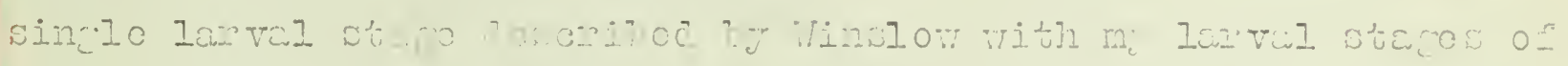

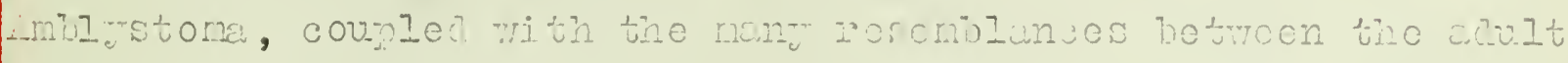

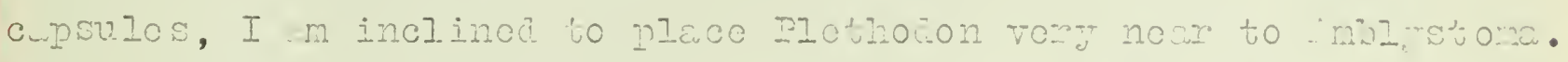

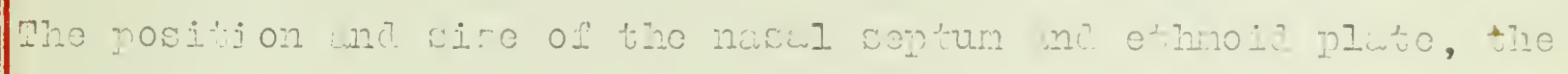
Iumin crijosa and its relction to the or can of Tacobson, tho lange

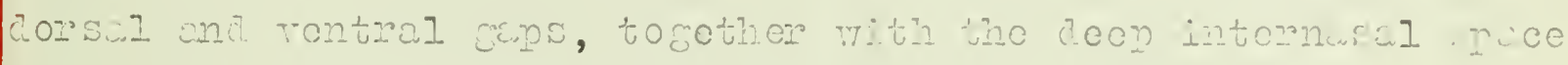

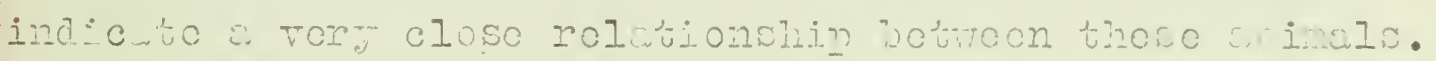



Dhe besis o: my study unon the nesal comeulo of impinine moans

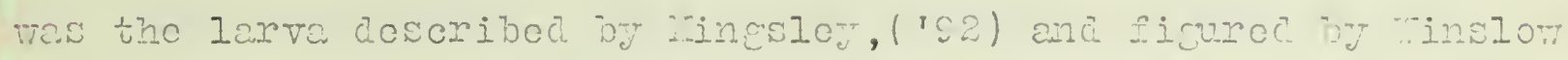
(190, fis.18). Chondrification of the nascl cande is not Jot

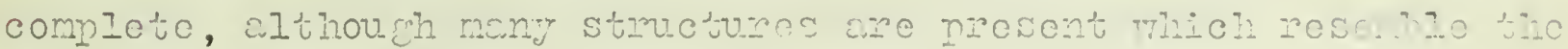
lartir cintulos of othor UTodolos.

Ihe trajecular crests aro elroak, voll. aetolopod and, antorior to tho eye, esch crest contimus cophalad as a smil plocoss which

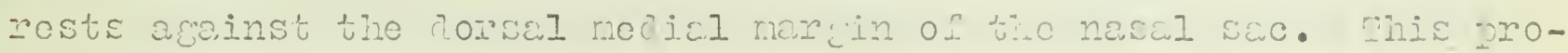
cess thon bonds laterally and, curving orer the torsal surfice of

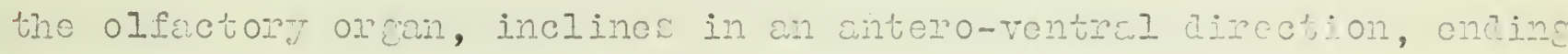

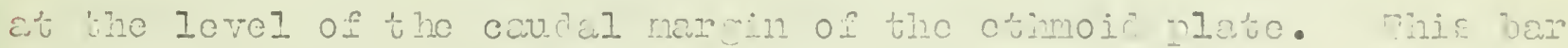
is the ously stane of both cthnoincl column and lamina cribose, which, in contrast to snblestone, arisos in mpliuma from tin co-

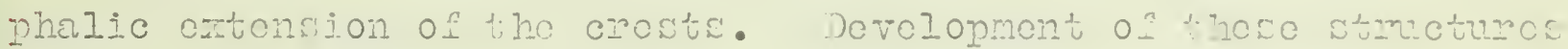

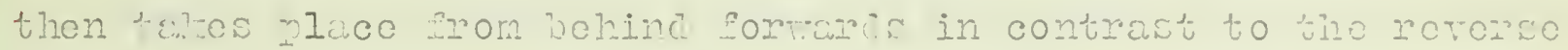
direction in the other mouns. The simificunce of tisid lot"ror

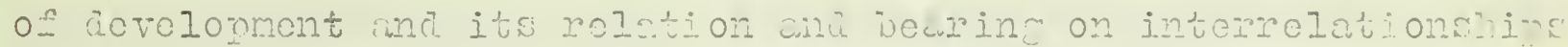

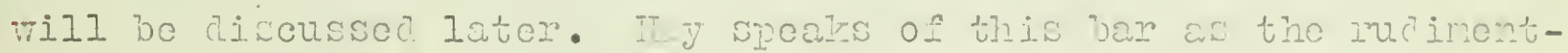
ary nasal capsule.

-nterior to its function with the lamini crivosa, the slenier

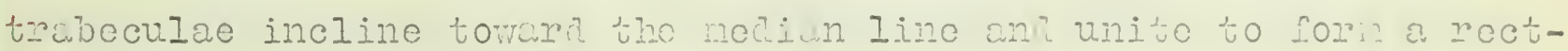
cngular cthnoid plate, wich is concure comsaly and sumonts the olfactory lobos which extend almost to tho cemhin ond of sho

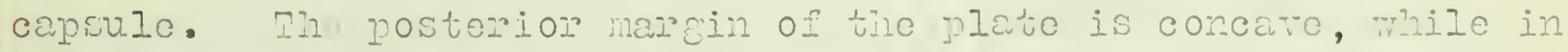
Front tho plate pases into tho cornue which hure a deen anc nar-

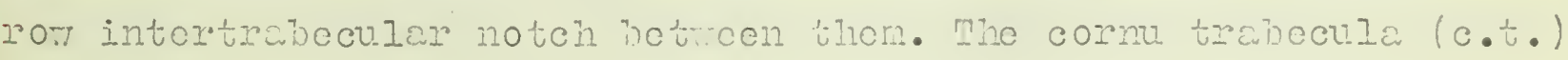

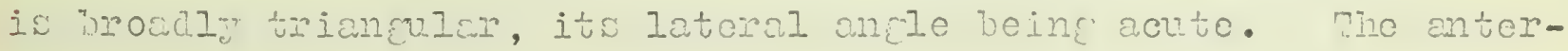
ior pert on the nasel sce losts upon the cornu, iut the eztemal 

nariul opening whd cophalic ond of the nawl sac are entorior to dul cartilege structures. Thero is no olfactory forcmon cnd uto olfactory nerve passes over the trabeculo anterion to the crista where nasal orbon and olfactory lobe aro closely apporimate. ․ small antorbital process (a.p.) cutends antcriorly from the ventral narain of the trabcula, opposite the orifin of the lamina cribosis and the cardel port of the nasul sae lios betreen it and the trabecula.

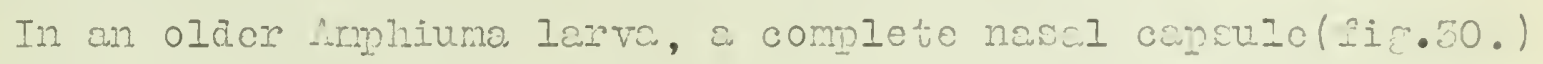
has beon forned, which is similar in some rospects to that of inblystoma. It is somorhat oroid in ov.tine, its croatest ricth bcing about a fifth its longth. Prom the anterior che of tho crista, each trabcula inclinos nedially, and, pawsing along the lonos mugin of the forcbrain, the tro unito at about the lovel of the ridde of tho capule, to forn tho cthmoin plate. Fis plate is roughIy horagonal; the postorior nergin is straight, milc cach laterel caudal. narein is curvec and is directod lataro-anteriorly to a point, corresponding to the lateral angle of the come of the comlior stage, whero it fuses with cnother cirtilago tret to bo doscribca. Tach latoral cophalic marein is clso curver and passos into ¿ procoss directed formard, tho anterior chd of the cornu; tre tro cornu beins separated or an intortrabcoular notch, widor then in the earlier stage. Thus the ethnoid rlato is united upon its postorior marein to the trabeculac, on excln latoral knjoct to a curtilace bar yot to be coscribed, and on its antorior marcin, it is continuotis into a pail of small cupanded processes, the comua trabcoulorum. The dorscl surface of the planm cthmoidalis is concaro either sice of the midule line, the midile of the olfectory sac reavinc in tize concertity 

Irom the median dorsal aspect of the planun cthmoidalia fuat posterior to the docp intra-trabocular notch, the short nasal sontum (s.n.) extends dorsolly, and thon dividos into tro broed burs which are directea from the line of the scptum at about an ancle of 30 despeos, to form a partial roof over tho nodicul surfaco of the nasel sac. These procossos extend antorionly and tominato blunty in a line continuous with the anterior ond of the cornu, while benind thoy unite with tho ethnoical colums.

The etrmoidal column now oxtonis as a slendor bar from the crista to the soptum, bending strongly toward tho midele line in its courso. The cinterion part of this column is enperonty the tectal curtilage of avthors. At abovt its midelo point it fivos off latorally a reducod lanina cribowa which bena vontrally ana laterally from the colume ethmoidelis; this part is broacen then the columina and forms the only lateral corering for the olfactory sac in this rogion. It thon continues formar as a nore slon on bar, which lies closely associdted with a longitu inal groove in the outer rull of the mascil sac. Abouts the letel of tho nescl

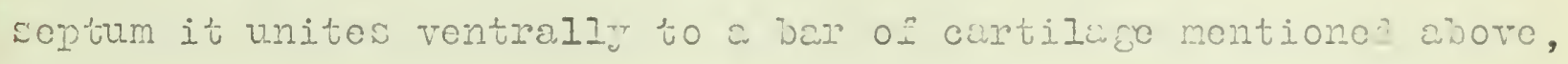

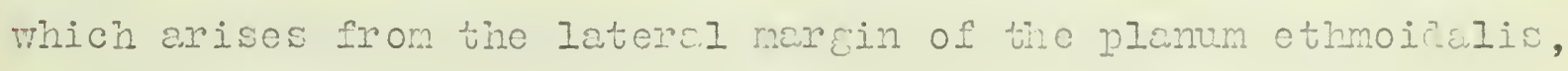
thus forming a broab plate mich covers the lateral suriace of the olfactory sac in this resion. The cartilige reanling from the fusion of the Iamina crivosa and the ber from the ethnoid ezitonds anteriorly and, at its distal end, oxpunde into a rine of cartilage which ontirely surmounds the olfactory duct where it passos to the naris. Ixtemal nesul lends mich lio boside tho nesal sac open into it by a duct which passes latenal to the antorior ond of the cribosa and the posterior side of the circumarial ring. 

Tho antorbital procoss $(a$.$) , in contreat to all othor Uro?cl-$

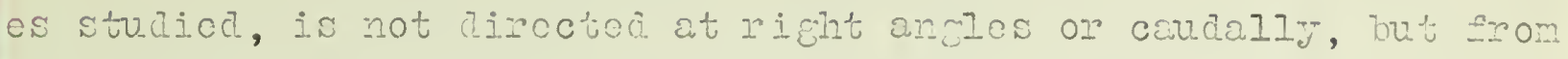
its junction with the trabecule it catends outward and formare at about an an le of 50 de rroos to the main caris of tho bo?t

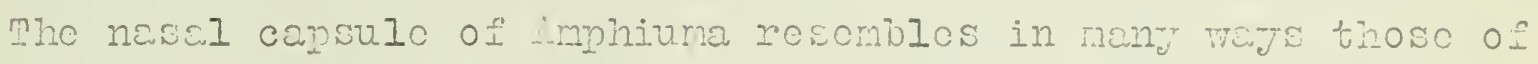
the other Urodelos above describod. Mle lar e vacuity in the orwal and lateral walle of the capsule and the consocucnt lect of sireletal protection of the nasal onitheliun is jin contrast to both Lmblystoma and Salonendra and met bo tho result of a roduction of parts. The septum nosi is recuced, but is comperible in its olisin to that of Cryptobranchus. The siz-sidcd ethroid plete is a fused cthnoid and comua, and the junction of the entorior cne of the elongate lamina cribose vith the letcreal procoss of the cthmoic is rocilily compured to tho bar of cartilaro unitine the conholic ond of the lemina and the cavdal ond of the cornu in sablyotone. Further, this bar holds the wane rolation to a vontro-latonal diverticulum of the nasil sac, which occurs betricon that structurc and the orman of Jroobson in both Amblystoma and salananiza.

There is a small modian nasal process in tho latucral frotth of cach columa ethmoialis corscl to its fusion to its mato to form the dorsal part of the sopturn nesi. The anterior ring of cantilage cannot be homologized with any similar structure of the hicher Urodelos, but the tominal position of the outernal nuis in Amphiura, in contrast to its latoral position in the colult :mblystoma, would occusion this modification.

In a larva $82 \mathrm{~mm}$. Iong anpeor nany of tho features that "ilder (192) has described in tho adult. Tho nawd cepsulo has doublod in $\subseteq i z c$ and thero is nore chondrification in the anterior 



\section{0}

parts. The crista trebeculae, antorbital process, ethmoidal column and lamina cribosa are similar in all respects, orcopt size, to the earlier stege. The extension of the columa etimoicalis bejond the nasal soptum has from forward and is now unitod in front to tho circumarial cortilago ring and to the antorior dorsal margin of the lamina cribosa. Thus a broad band of cartilago is formed by the fusion of etrmoidal column, Iamina cribosa and the circumarial cartilago which completely encloses the antorior third of the olfactory sac, oxcept on the ventral siae, Together with the nedion nasal process and the othmoidal colum, it forms the roof of the carsule. Iarge formen in this plate conducts the rams superficialis from the censule to the dorsal recion of the snout, while a small formen in the lomina cribosa near its fusion vith the latereal orocoss of the ethmoid plave allows the rama clancularis nerve to pass through the capsulo to be distributol to the oxtom I nasal Glands.

In the chondrification of the anterior prrta of the capulo a large fontanelie has formed betwoon the etimoicic colvm and the lamine cribosa, which rowembles in mny wors the laree cap on the dorsal surface of the capsule of the adult imblystome, inclosed by similar structures. To olfactory foramina has beon formed, nor doos Wilaer show one; but the olfactory norve passes underneath tho othmoidal column just posterior to tho scptum nasi. The antorbital procoss extends anteriorly and is closely associated with the nasal orgen, but it has not united to eny capsular structure, nor do I Inow of its association with the lamina cribose in the later stacea Which is so charsctoristic for all othor trodeles. 

Irecturus maculetus.

In the larval stages of recturus, tine procoss of chondrificetion is eroatly retardod, so that thore is no ovidonco of a nasal capsulo, beyond tho mere oxtension of the trabculae into tho head rogion, up to the $25 \mathrm{~mm}$. stage. This is in marlad contrast to the condition in both Salamandra and imblystora, in mich a more or loss roll-dofinod nasal capsule is alroady laid dom at that sizo. On tho other hand it rosembles spelerpos in winh the difforontiatod capsule apporis ropy lato.

In a 24: mm. larva, the trabocular creats aro not doveloned and the cylindrical traheculae incline fovar cach othor, but the ethmoid plate is not yet formed. There is no oviäonce of a cornu at the anterior end of thesc bars, nor has tho cntorivital process formed, but the prosence of procartilage colls noar the traboculce indicate its later dorelopment. The forebrein lics latoral to the nesal sac througnout its ontirc longth and roches bojond tho antcrior cha of the urabeculae.

In a slighty oldor stagc (fig. 25), the cophalic cnis of tho trancoulco arc closer to ewch other and have crpandod dorso-lateralIy, so that a cross scction of the trabocula in this recion is roniforr, similar to the sume ber in spolcrpos. Jiss platt ('97) hea described the indenenicnt chonarifiestion of the otsmoid plato, and its subscoucht connection with the trabcculic. I heve no stage showing this condition, but I have obsorvod a fow small cartilano colls lyine in the tiswe botwcen the trabculac, near their antorior cnis. This may bo the becinnin of the ctrmoid plate as describcd by lisis. Platt. The forebrain still oxtends anterior to all cartiluges, and noarly rocohes the anterion end of ho olfect- 

Ory Or man.

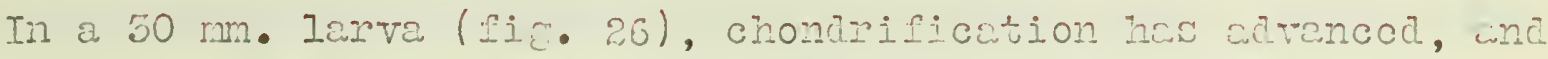

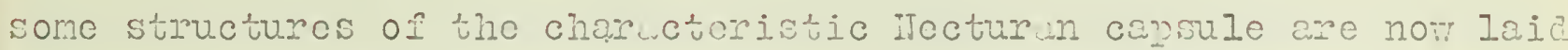
dorm. The othrnoid plate( n.o.) now unitos the traboculiso; it is

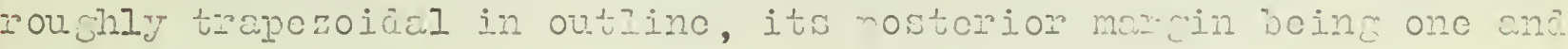
onc-half fines the loneth or the anteriol. Its lutoral man wins aro thickor, tho rowult of tho trebocular swollines, and theso thicleon-

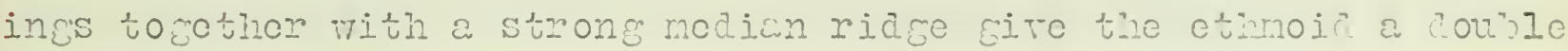
concutity. The nasal septum (s.n.), although slightly ovidont at the postorior markin, is more nrominont in front whe thus cives the antorior half of the plato a decidodly conver surficuce. Interior to the planum othmoid Iis, finc traboculac ertond formere cas cornua, a distance cqual to one-half the loneth of the plate, then cech tominatos chmmely mithovt tho latorul oxmension, mich is so charactoristic of tho traboculac of ovon tro younco fmblustona Iอrvac.

The besiming of the well-lmom sonostrater nasul censule cor-

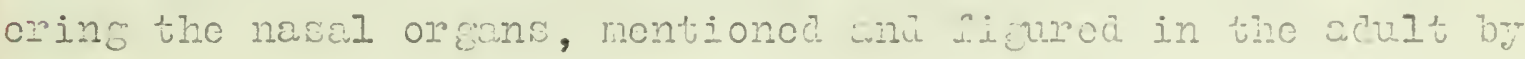
ricaceshoin ( 70 ), is formec in this stwge. Dircety over tho nasul sac and some distance from the trabecula, is a namow bar of cartilago, tho columna ethrnoidalia (c.e.), mich is not unitod to the other parts of the capalc. This bor chondrifics indoroniontly just as in Anblystoma, but in contrast, thoro is, as yot, no ceudel capsular structuros. vtarting at a level slightly cauda to tho ethmoid plato, it runs forward and modicllor possing alone the dorsal nodial border of the nesuI sac. It torminatos at a point a Iittlo in front of the comua. I rogari this ben as the homoloere of tho colvma cenoidulis of the othor Urodolos, although I havo 

not socn its origin. In 31 and $20 \mathrm{~mm}$. Iarvoc, its incroasen caudal cutcnsion leass no to concluce that it acvologs from in front becl-

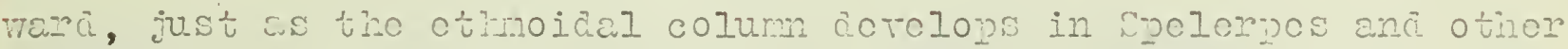
Trodoles.

In the sano stagos I heto observod choncrificution and curt-

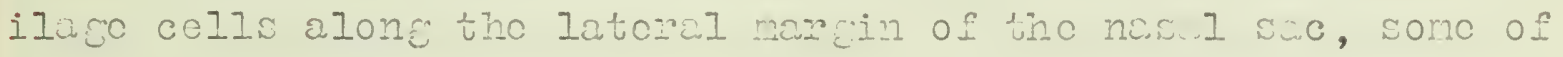

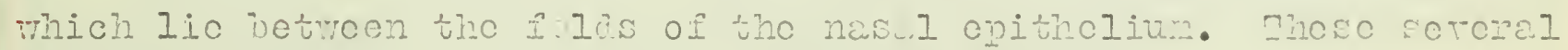
arois do not socm to ariso Es a conuinum, but choncrifu indoncneently and subsccucnty boconc connccted to form the roof of the fioncotrated capirie.

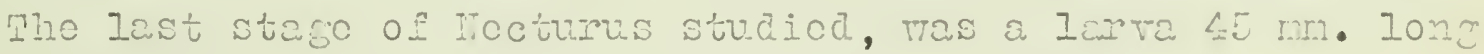
(sig. ar.), in which tho fonostrated nasal capsulo (fen. pr. ) has

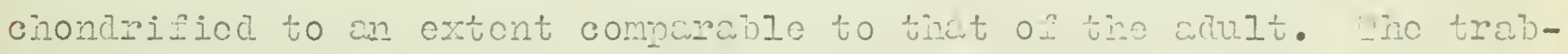
coulae (นُ), othnoia platc(p.c.), scptun nisi(s.n.), and the trabecular extonsions are sinilar to thosc of the nlece ing stane, ilifforing irom then onlJ in size. The coptum ncis, nomeror, ins suffored a roduction and nchec the anterior mancin of the cuimoid plate

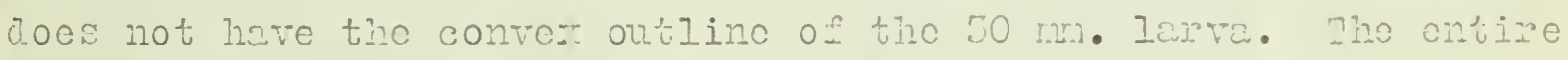

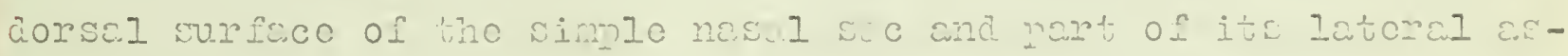

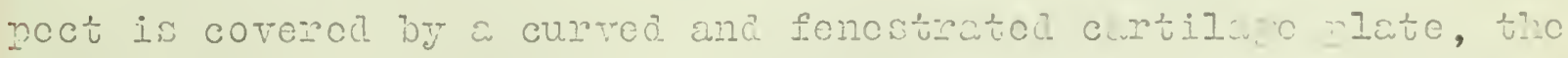

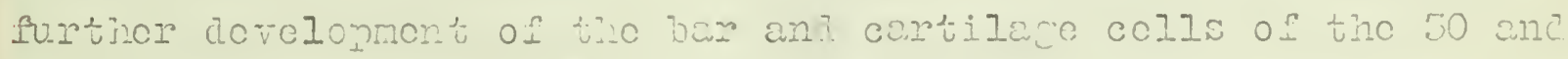

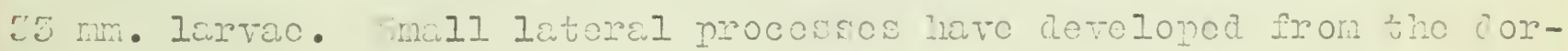
sal bar, and thosc hato unitod, Iowting a womies of smell ovonines

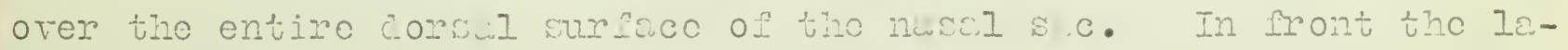

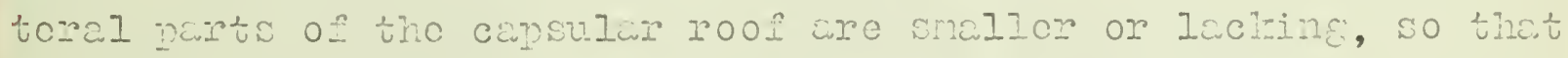

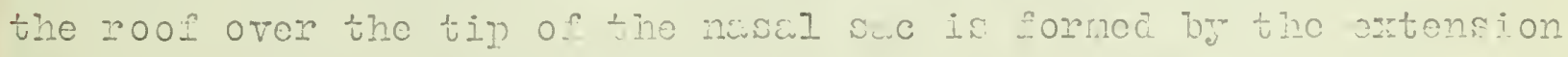

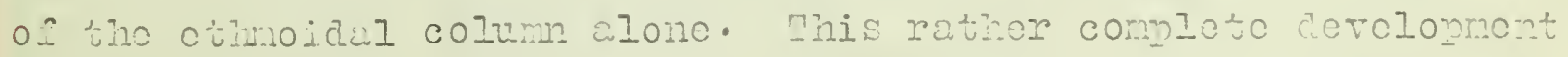

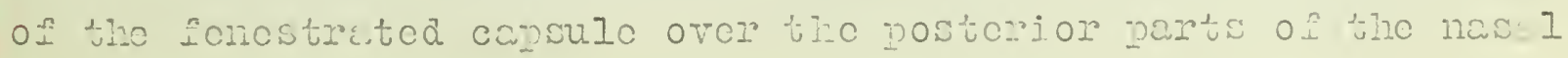



sac and the recuction at the anterior cnd, indicates a dorolopmont hore from behind formans. This is in accord with the aircetion of frorth in the chondrification of the lamins cribose and tho racien nasal procoss of the highor Urodoles, and, althourin theso narts are Wholly separatod from the trabculao, Jet the fonostrated capsule of Hecturus is the probahle homolove of the lanina cribowa and the cthroidal column of tho typical troiolan cspulo.

The antorbital processos (a.p.) are rell-heroloped but havo not unitod to tho lattice-worlz consule, nor is this relationship ever ostablishod; wlthough tho cpproximation of tho latonc roof of the cansulo and tho antorbital procosa is close.

The carly stafos of the nasil capcule of lecturus resomble in many vays those for other Urodelin Iarvac, to this certain outent: tho traboculac with their antorbital nrocessos, tho othnoil nlato and the colvmmo othnoiculis all rocull thoso structuros in tho other Urodiclos; but there are considorbio differonces in the nothou of origin of tiese partis. The incoponicnt choncrification of the ethmoid plato and the absonce of latoral ctrpunsions of the tipe of the trabculac are foctures not found in the othon crours; on tho other hand the dircetion of the chondrificution of tho ctinoical colum and tho fenostratod capsule, rosonblos this mocess in imDIJ stona.

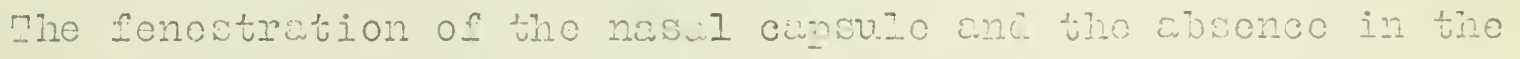
Intor stegos of a septum nisi, to gethon with dhe reme unspocialin-

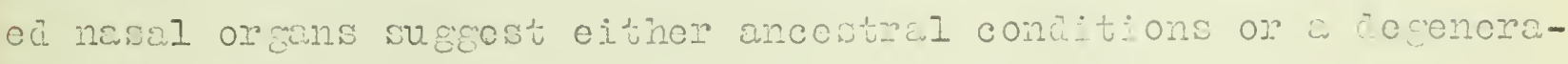
tion of ports. To rocord lecturus, Tith its conostratod nand echsulc which hue no counterpurt throughout tho ontire trodolon orron, 



\section{4}

as primitivo, would be unjustificd; but, its vory belcued procoss of chondrification, the absence of cristue and comnu, tocether with the cntire soprrution of the roof of the nesw cunsule from the ethnoid plato and the trabeculwe, may be emlainod in oithor of trro ways: Tecturus ha oither desconiod from aome noro specializod Urodolo, liro ipolernos, or may moprosent a neotenje conition. 

Tipicrium guvinosves

Consicrablo divorsty of opinion has oristod in tho past in recard to tho phyloconotic position of the amophiona, or bline footloss impibia of tho thopics. Topo('8s) classed thom as a family of the Urodeles, the daceilidae, rolated to tho hichor Urodoles throusin impiuma. Tho cousins arasin ( 'io), rollowing ropo, also recardod thom dos Urodoles wh veliovor thon to bo a noo-

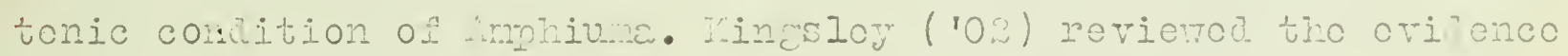
as to the position of the groun, showing that mun of tho points suprosod to indiccto rol tionships, wore basod un erroneons

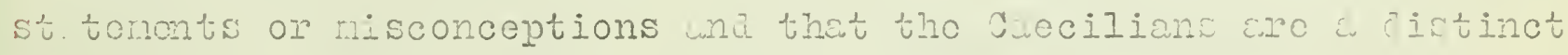

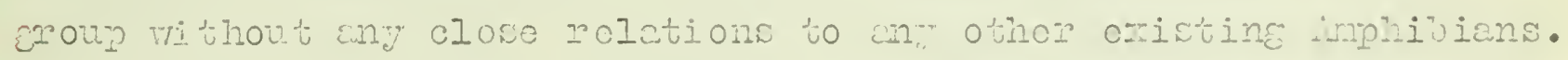

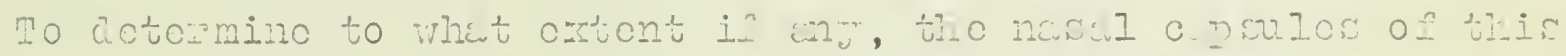
order would shod light on thoir rolitionships to tro trodolos, two

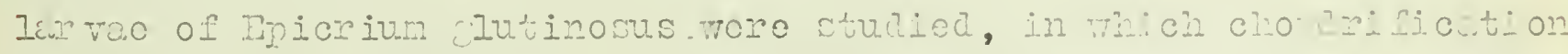

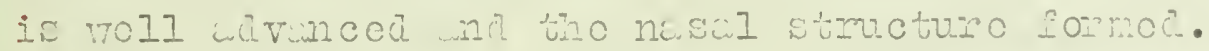

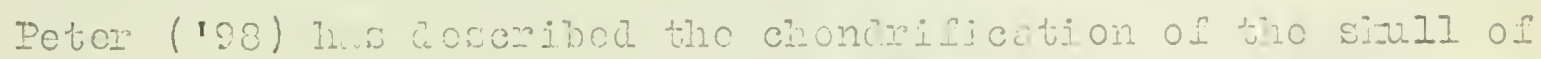

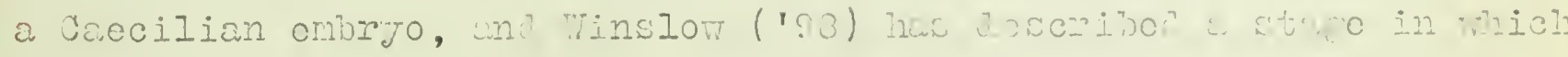
tho ombro is till spirally coiled wituin tiro of,

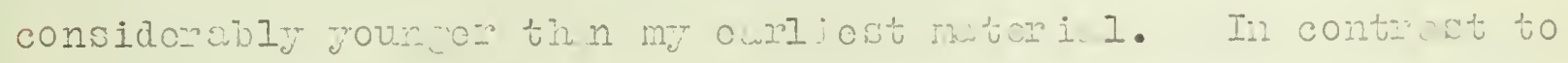

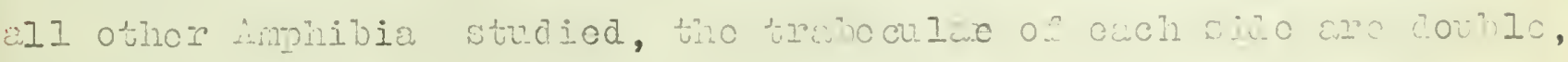

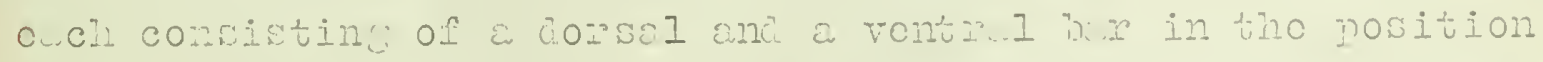

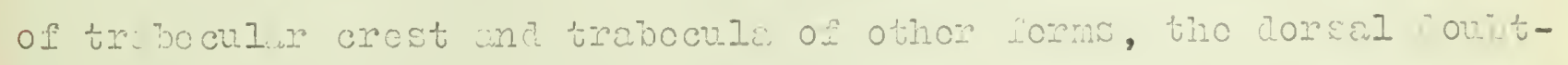

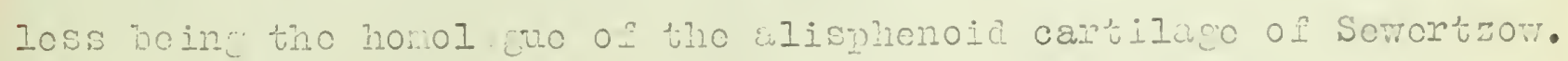

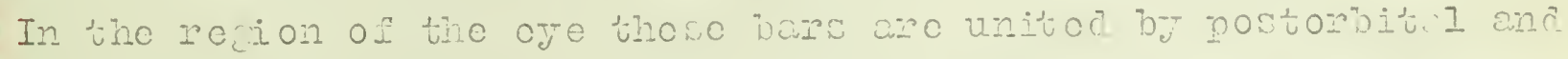

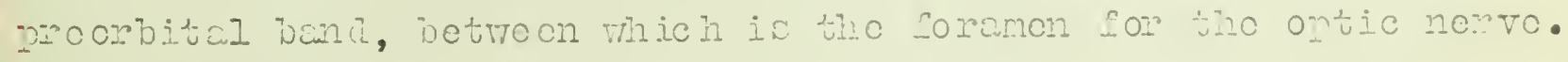

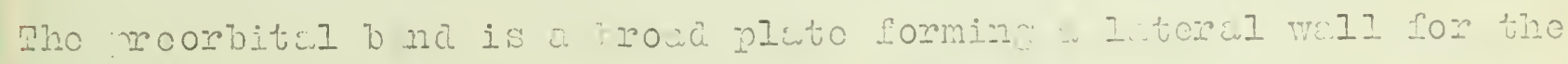
anterior rart of the bro in caso; just bohind tho chocme it divites, 



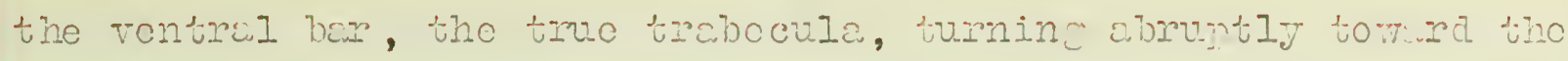
median lino to unite with tho tratiocula of tho opnosite sino to form the othmoid plate $(p . e$.$) , while tho vnou portion crtonds for-$

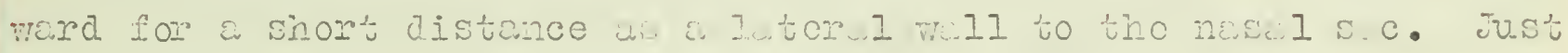
whorior to the proorbital bond, this wall has a slicht roote

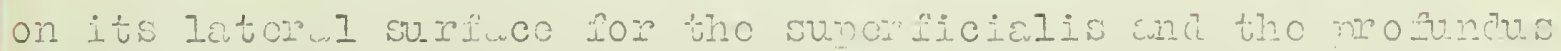

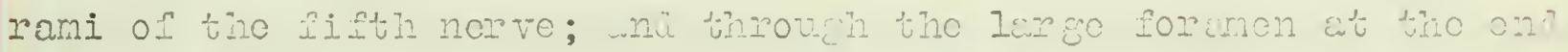
of this crosve the suporficiulis ontus ullo cupsulo, whic tho po-

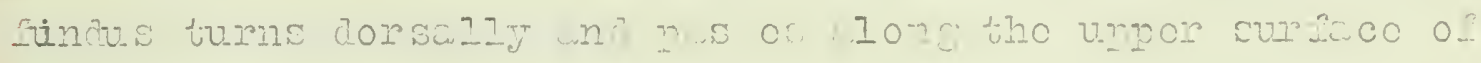
nives organ.

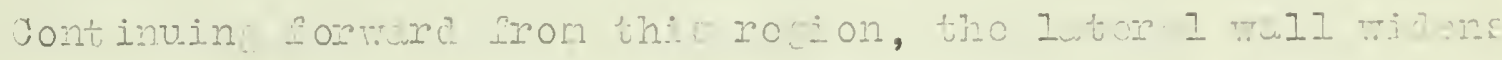

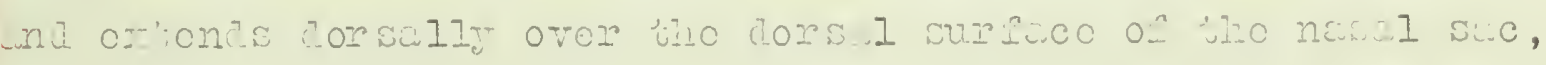

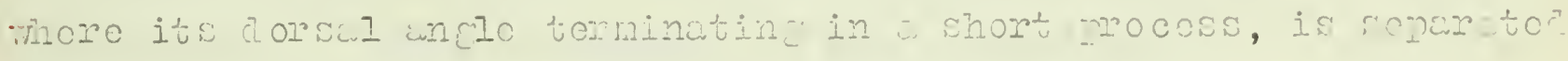

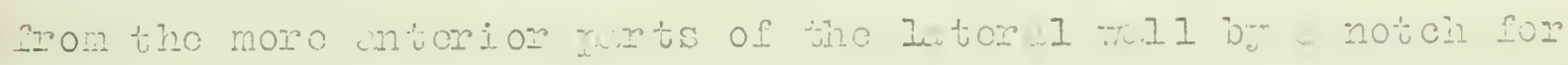

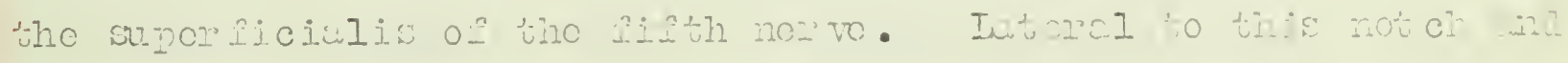

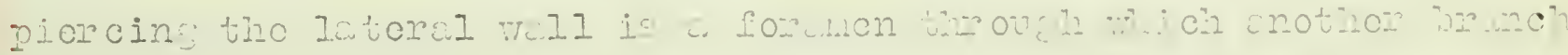

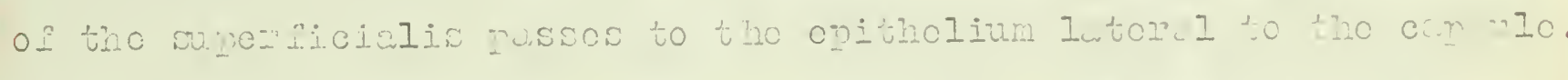

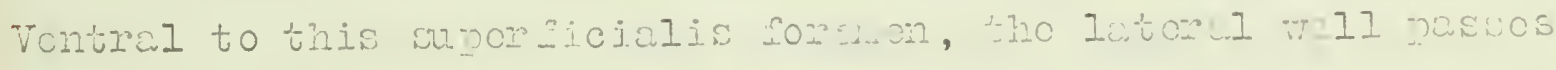
tontrally ne nedialy into w ben, tho solum nasalo ( so.no.) o ? Peter ( 108$)$ winch joins the etinnoid ploto.

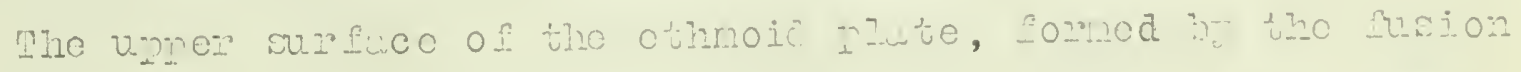

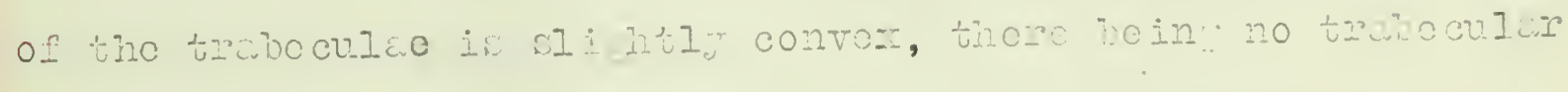

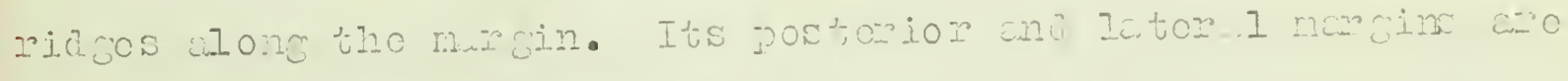

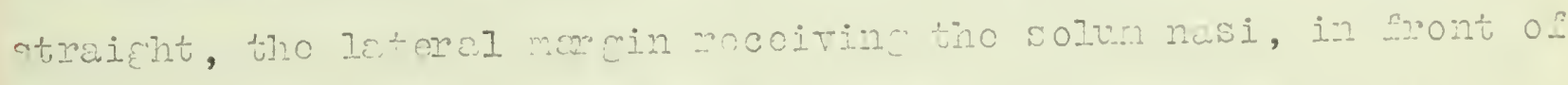

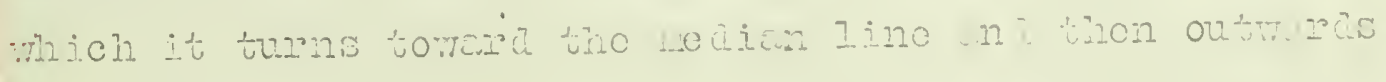

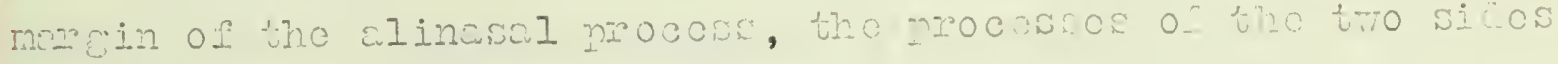

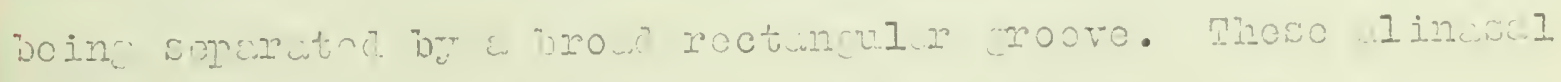

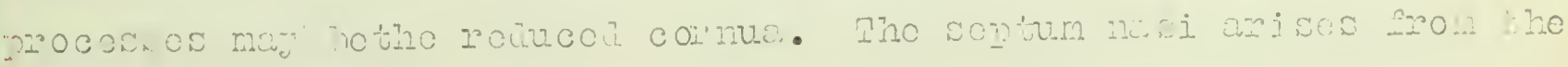





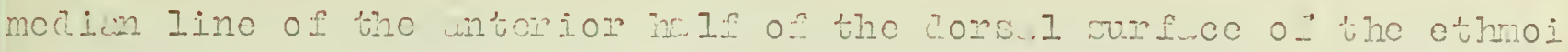

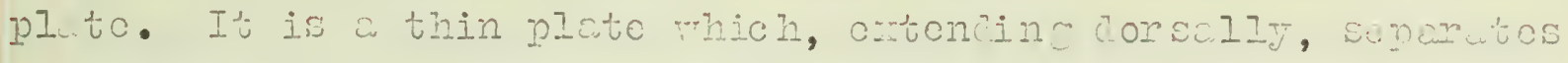

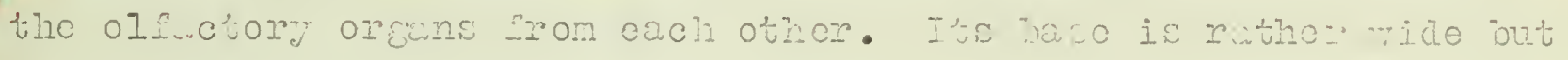

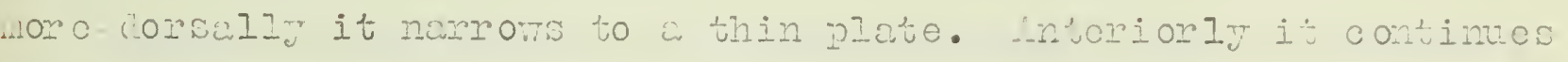

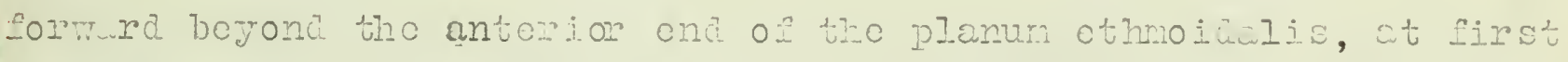

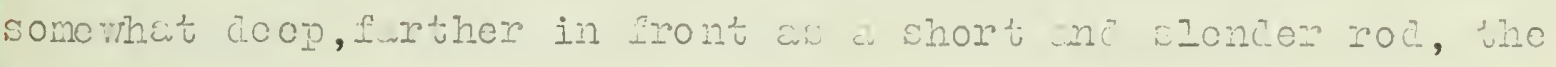
rostrum (r.). Lt the junction of sontum win. ostrum are the pro-

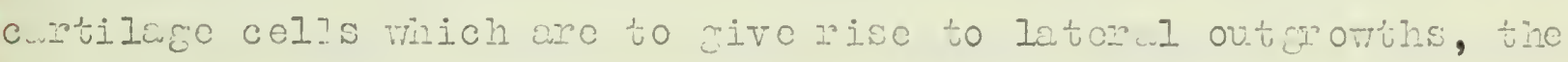
alciry proconses of Petor.

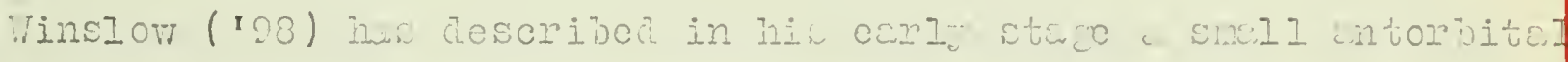

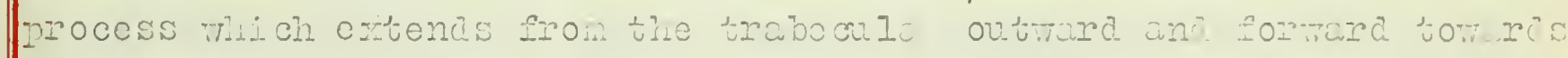
the lanin cribose. I do not find in antorbitul mocos ac such in

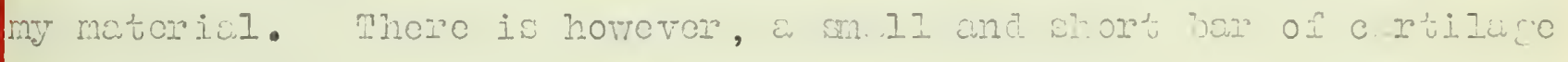

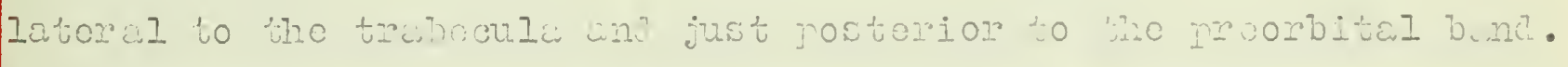
It is not in comection with tho treboculcre rods wt wh tine, but

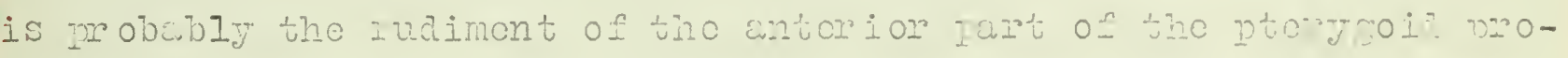

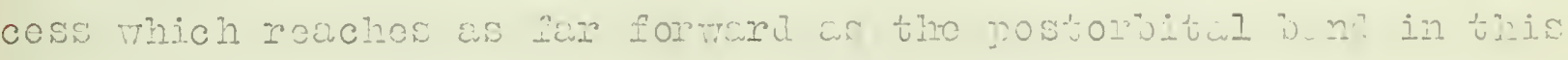

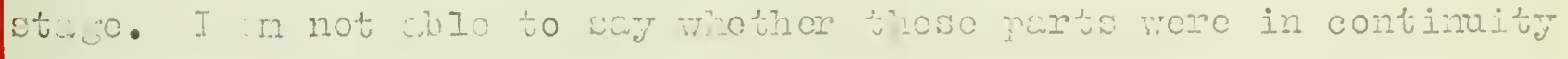

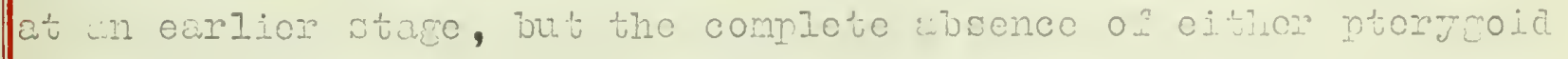

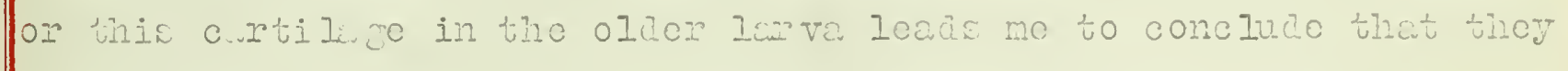
how aro in tine procoss of rosorption and that they mar hewo locen connctod at an ocmlicr stace.

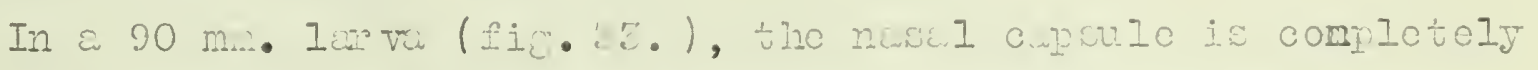

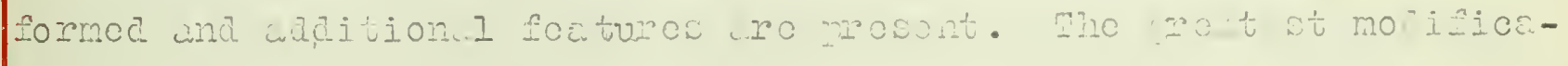

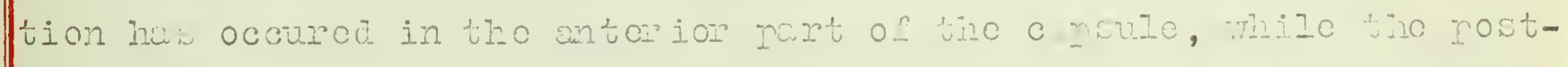

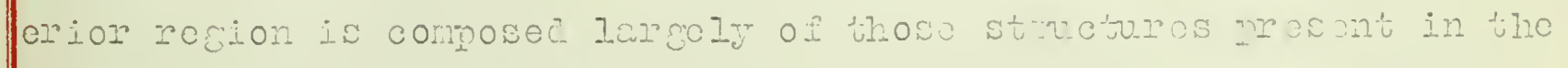

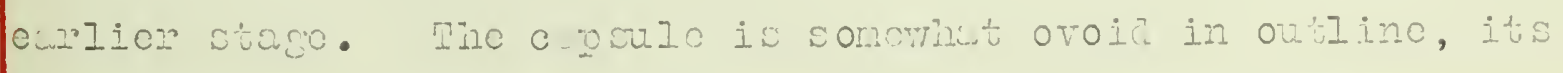
meatest widsh bein hout one thind itu lenguin; win in contrast 



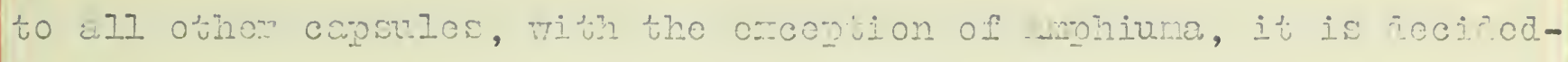

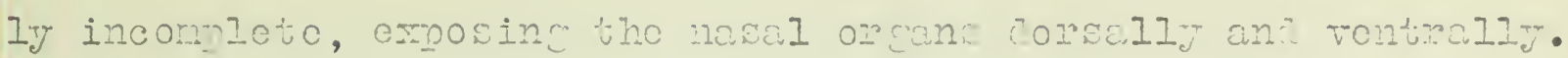

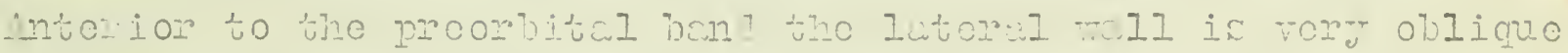
the ventrol worein bein men funthon from the morion lino than is the

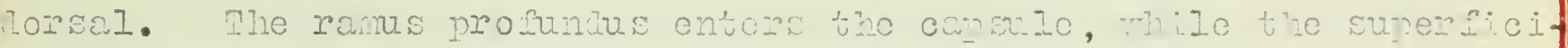

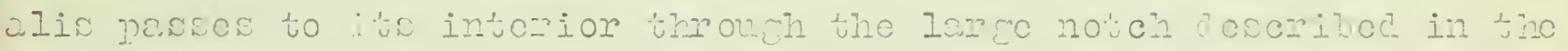

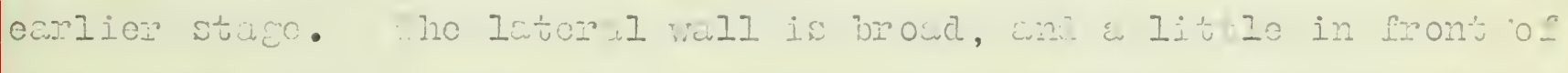

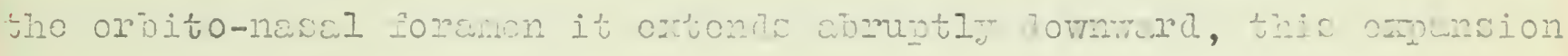

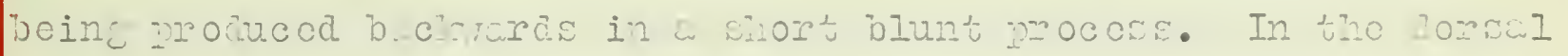
part of this capinded portion is the forwon through which the aro-

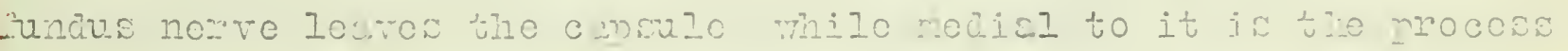

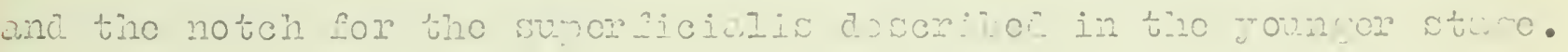

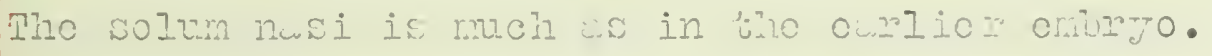

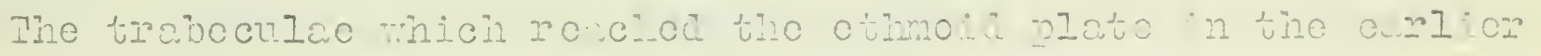

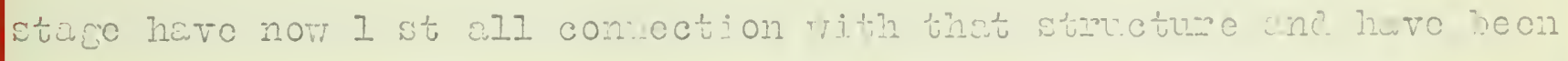

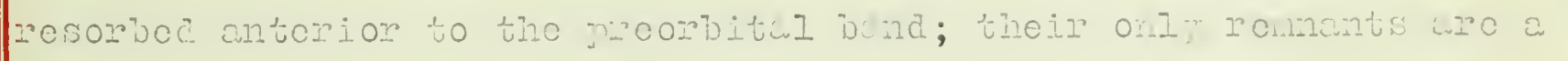

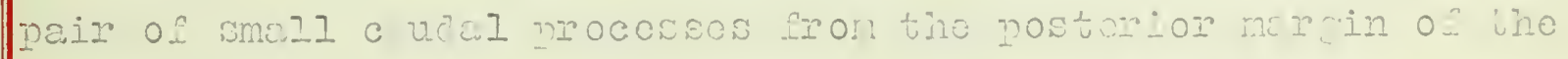

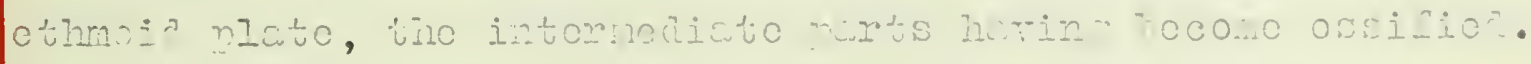

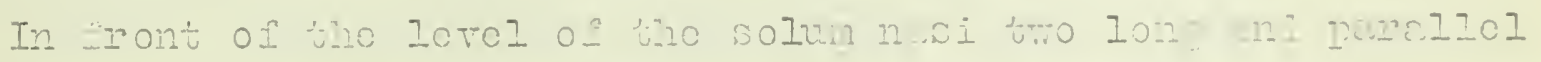

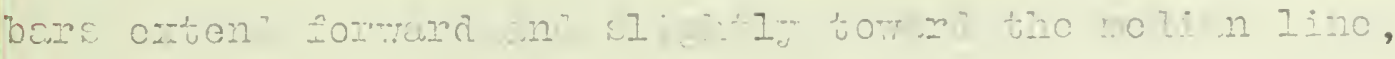

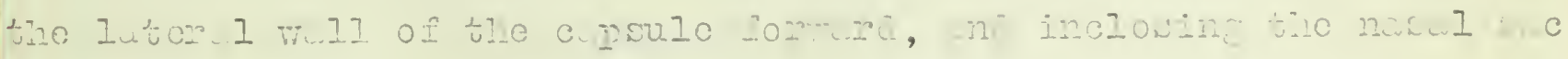

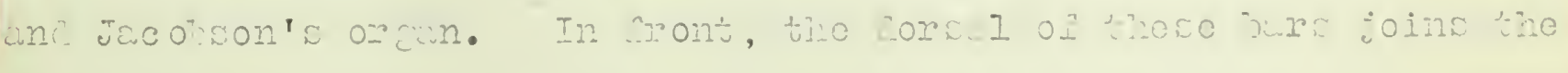

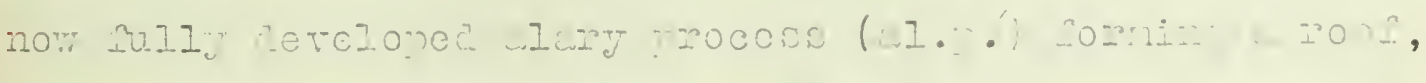

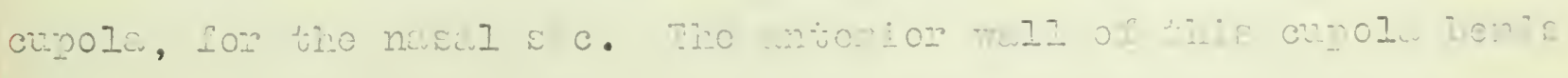

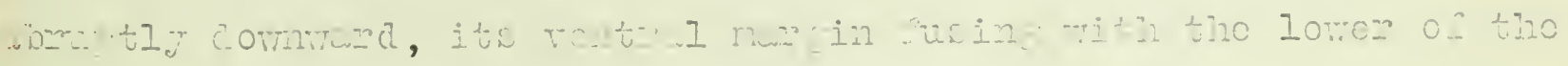

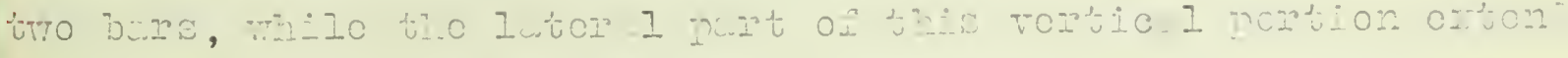

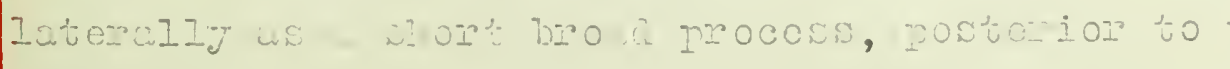

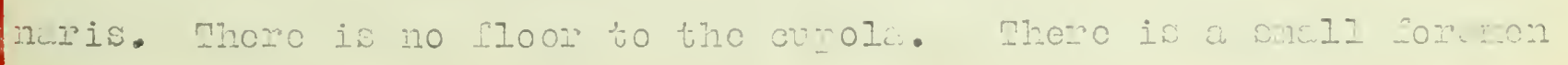





\section{9}

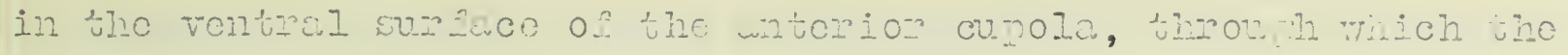

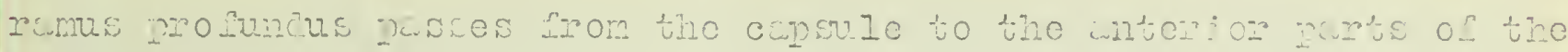
ฐnout.

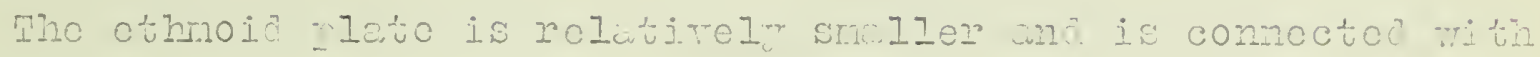

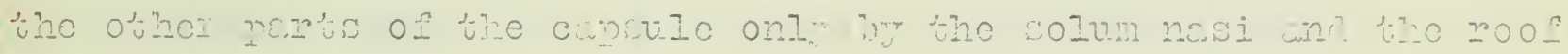

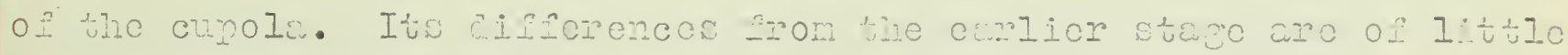

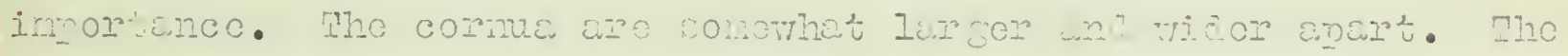

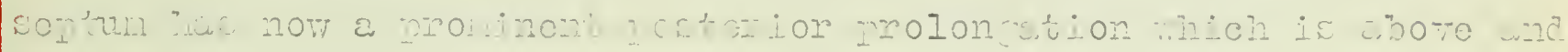

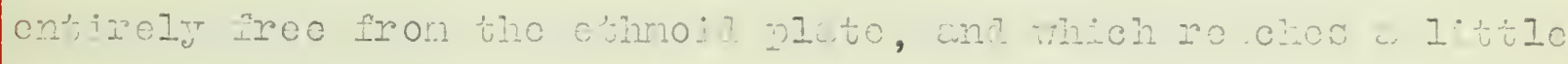

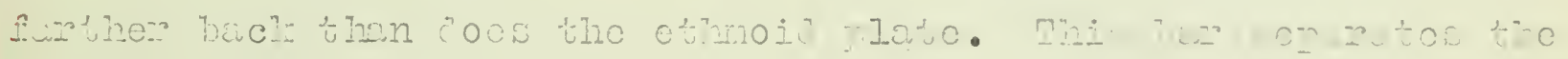

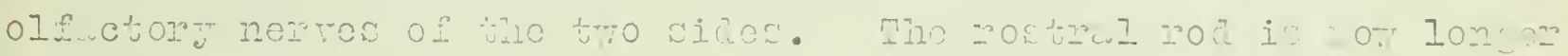
will SIencomon then Dofore.

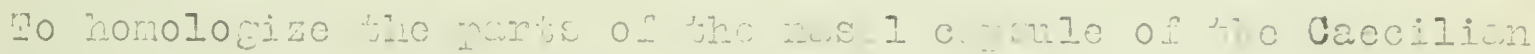

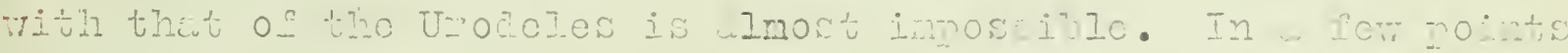

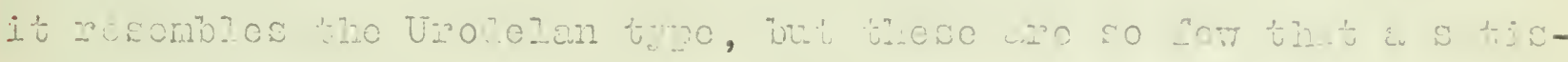

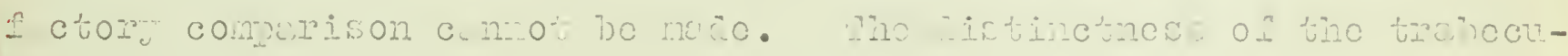

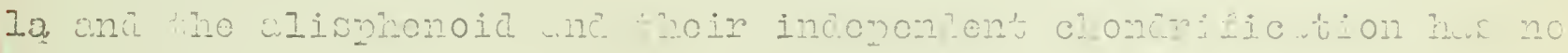

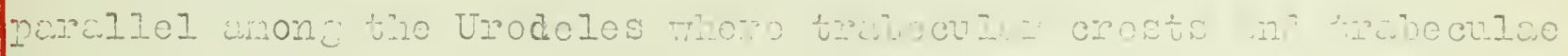

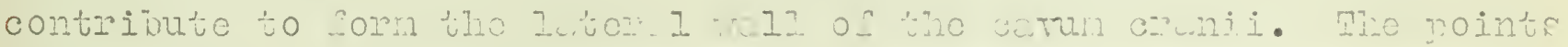

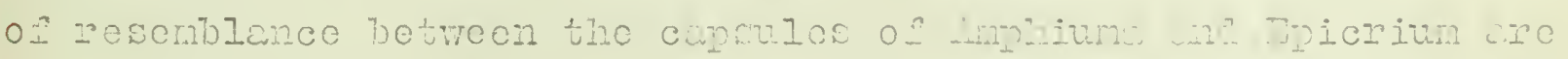

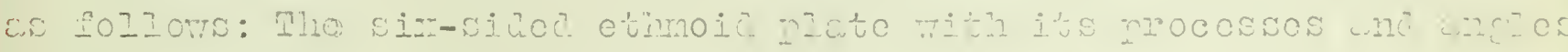

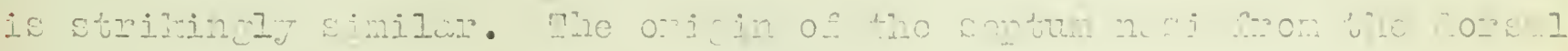

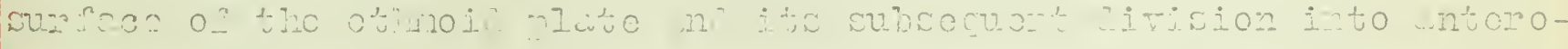

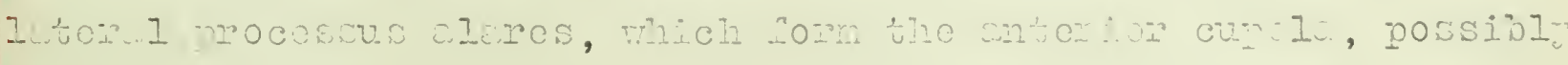

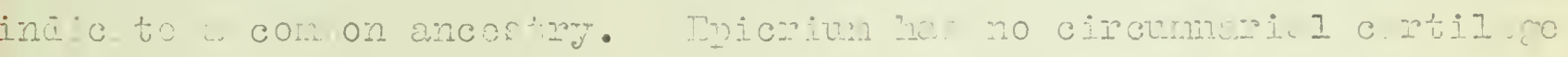

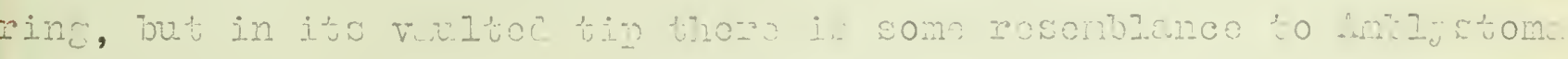

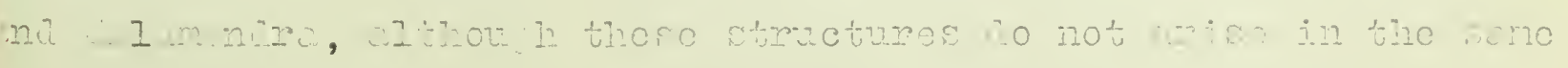

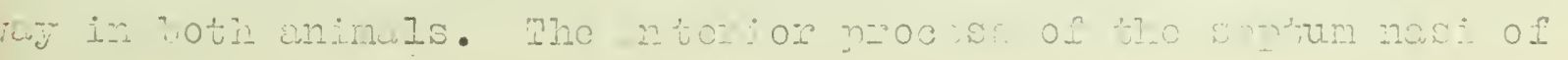





\section{0}

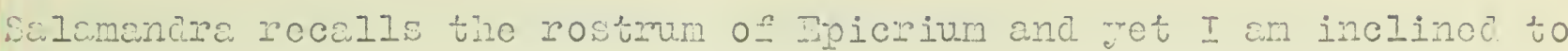
bolieve that this reseminec is one of converence rathor thon of inherisance.

In sencral the capulos of mpinue and picuiven are similas in the following rospects. Mine absence of olfectory forcmine, the

Shann of tho cthroia plate, the nosul soptum and tho slight outent to Which the nosal copule is roofec by cartilage structures, cannot be orerloolicd. The cupola of the capsulo noy be the result of the burrowing habit and habitet of this bIind cunimel. 



\section{Uro olin jo rimisons.}

Upon tho basis of the nes. I cansules of soreral familios on trocielos, this omen mer be dividod into four mouns, basod unon wimiIarity of larval structures anc tho nrocrositu method of cionimificat tion. Finc lapsest group comprisos Gryptobranchus, spolopos, Plotinodon and imblystoma. The socond incluios walumandra, Triton and

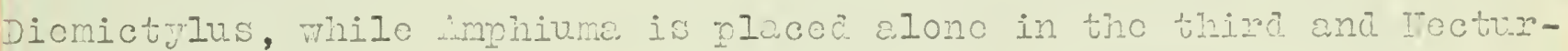
pos forme the fourtin roun.

This classification is based alnost chtirely unon sinilanities of nasci structuros curring tho larvi rovolopment. In sono fom

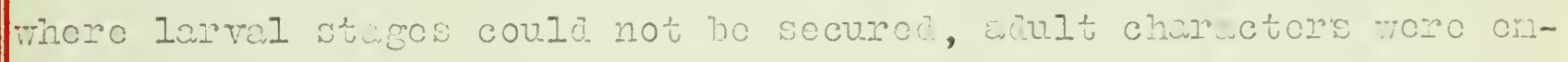
ployed; mile in othors the owlor nothod of chondriajection res the only criterion available.

To recomize in the nosul cepsulos on the Urociolos a complete

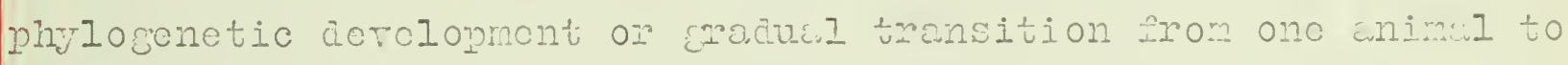

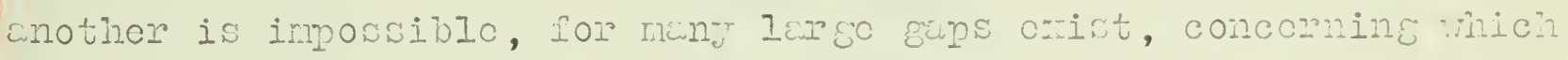
ovidonces of structural rolationships wo rantine. On tho othor hand many resomblances in she developnont of cortain structures Of the nesci capsules mey tinos sono licht upon the intomalationwhips of this muibien onder.

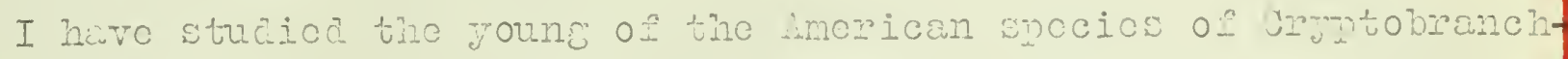
us. It would room as if tho camsulo of thir wimil possosdes charactors that anpear mow ancotral and micl shom rolationshins to Doth tho Urodolos whe tho inuma. Tho Joungost larva of cryptobranchus, which I have studied, has a rell doteloped trabecular crost wich is not penont in tho composponiting stegos of eithor pelorpes or Amblystom; the cotolopnent of tho crost of imblustoma boing apnarenty correlcted with tho dovolomont bectrand of tho 



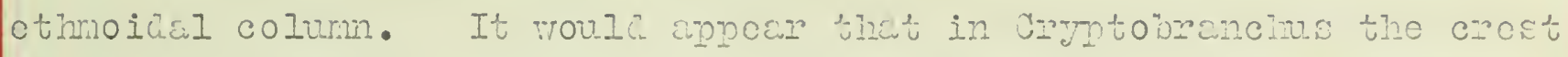

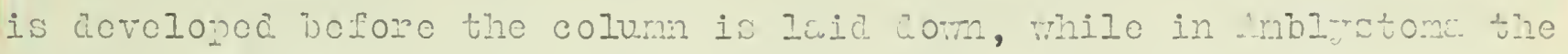

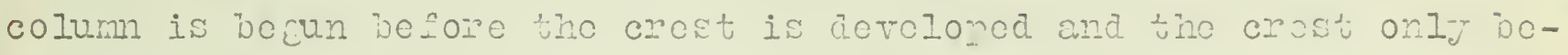

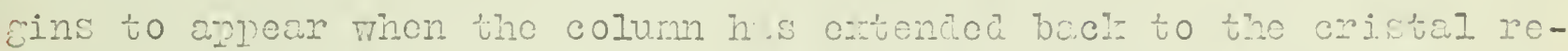

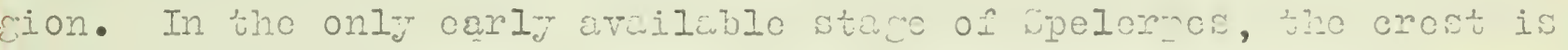

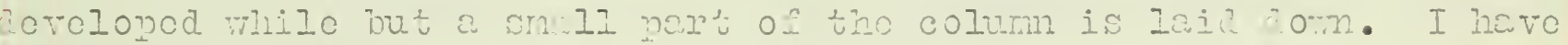

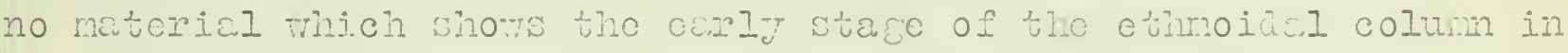

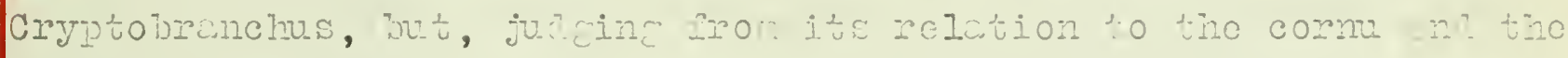

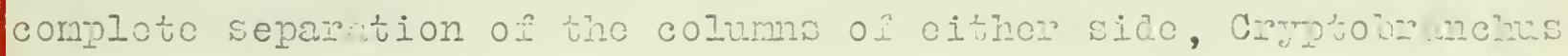

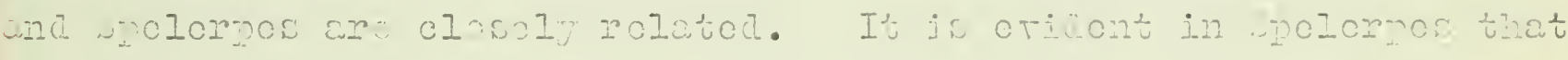

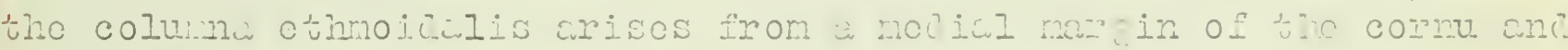

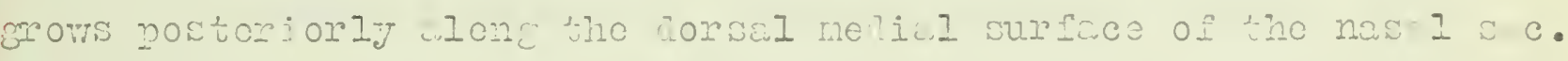
Ey oldest limva doos now show the fomation of tio compote column,

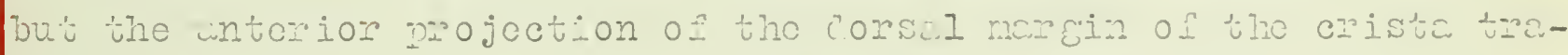
Decula sugecsto tin t the ctumoidal colum in polomes mo inise from

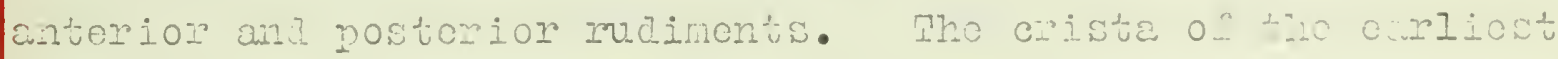

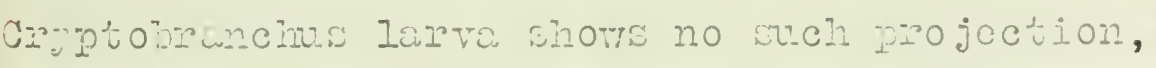

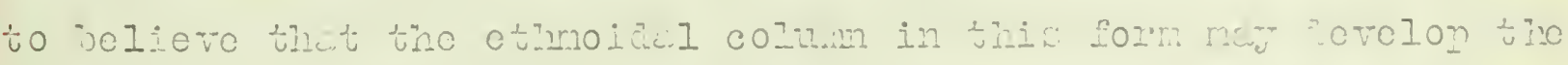

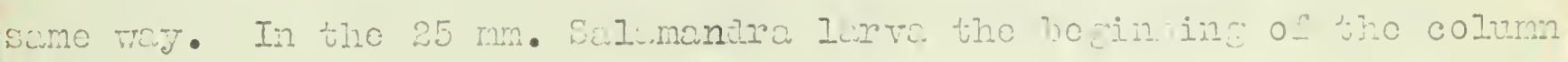

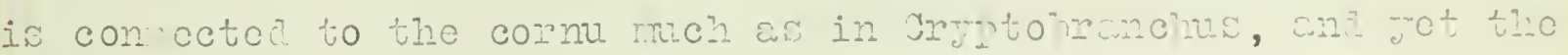

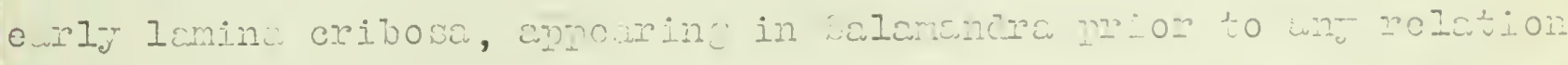

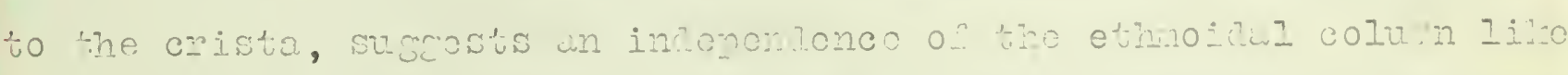

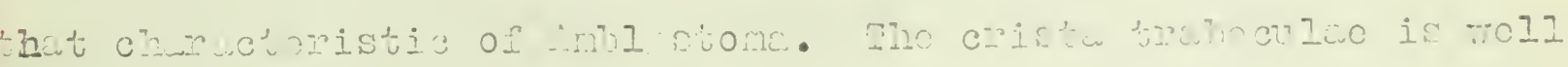

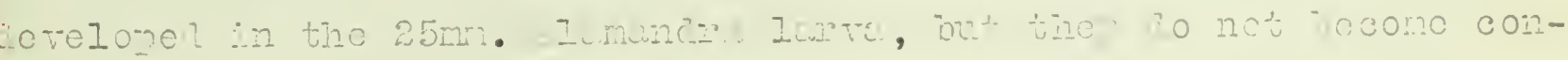

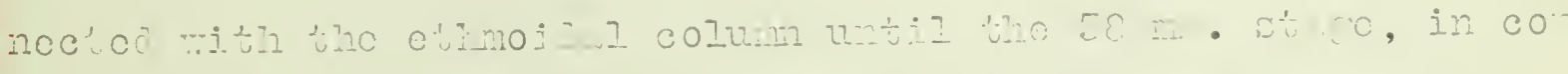

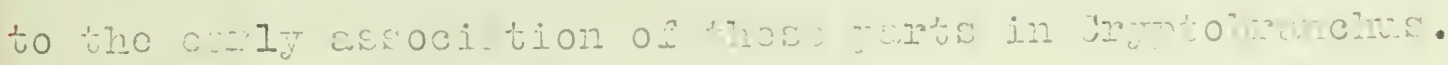

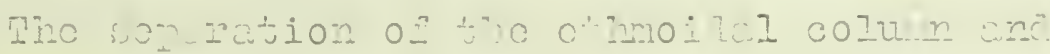

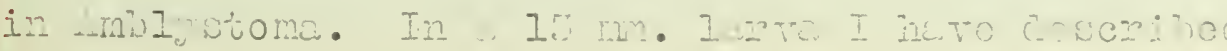





\section{3}

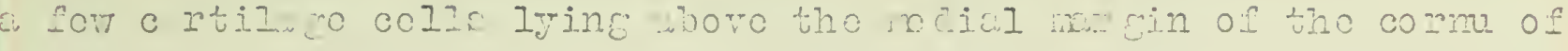

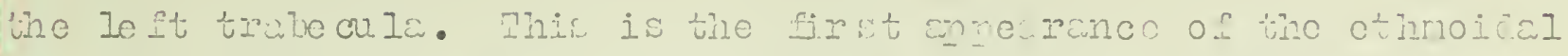

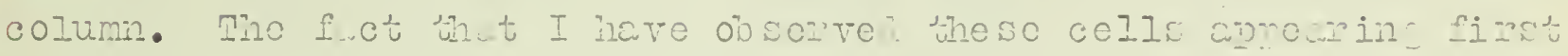

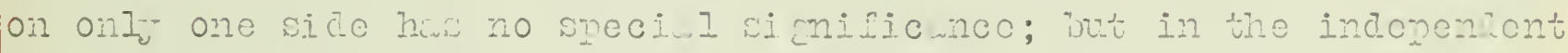

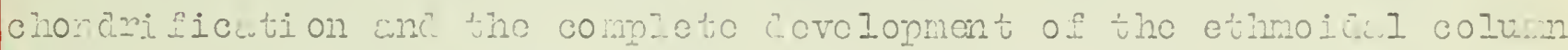

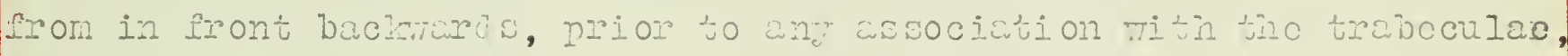

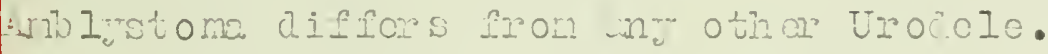

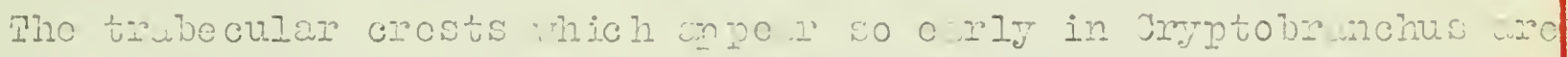

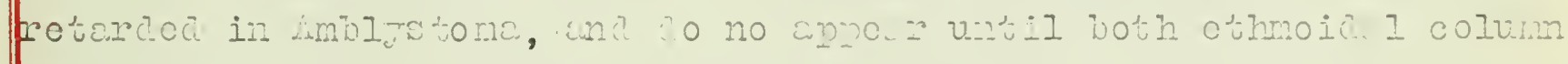

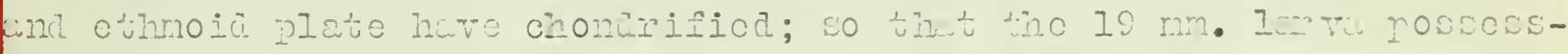

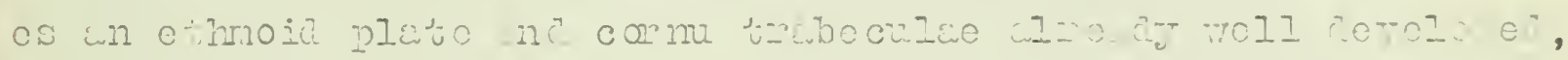

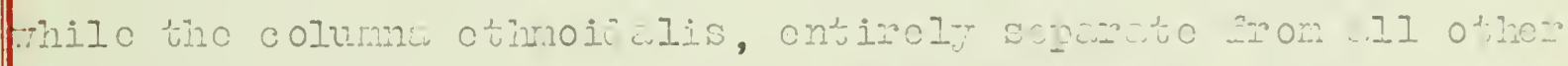

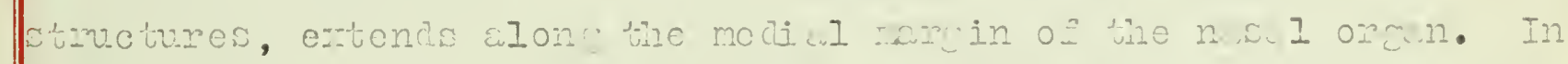

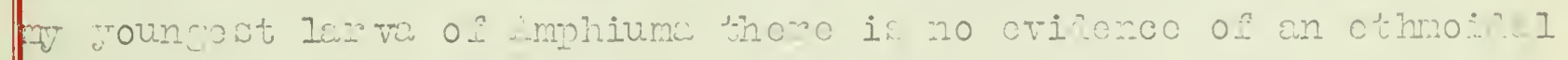

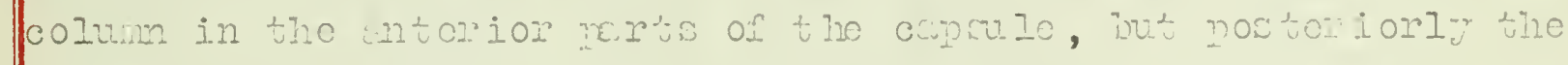

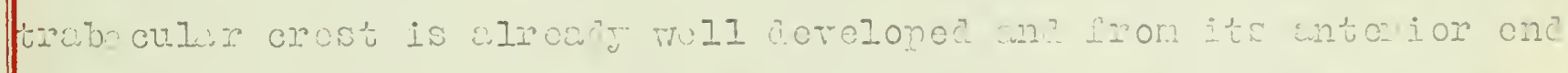
comile rod
swos antonionty

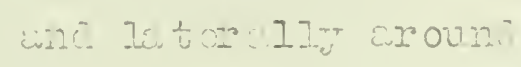
1 orenn.

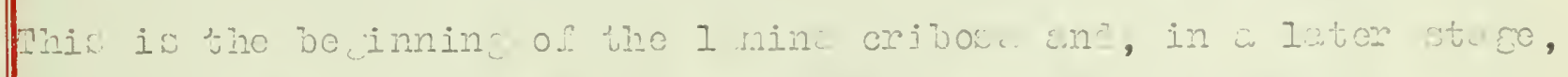

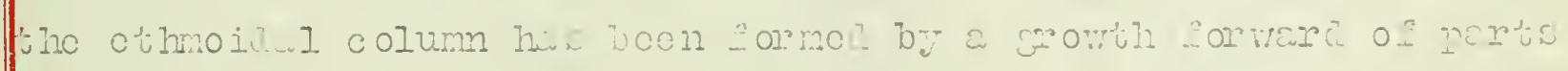

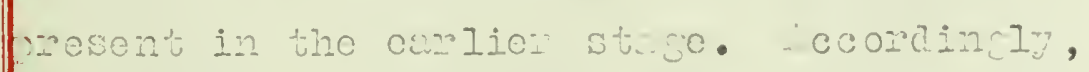

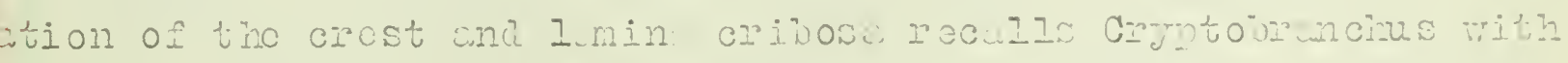
Fich I huvo associatod imhivma.

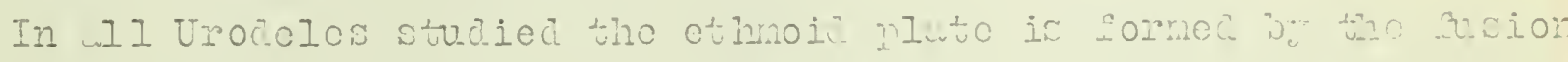

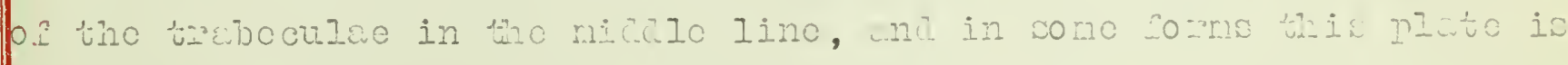

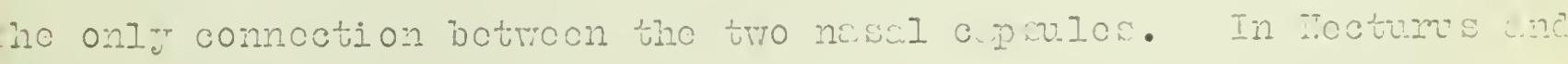

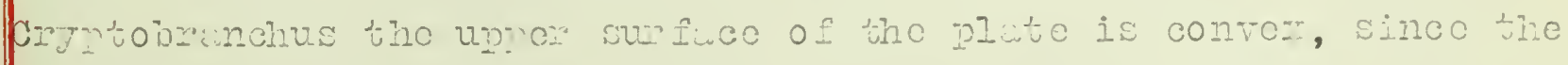

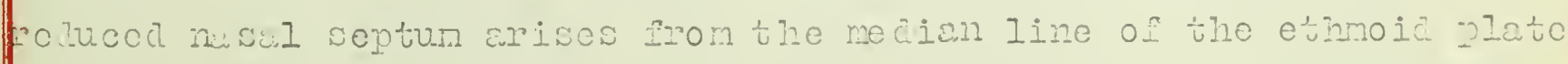

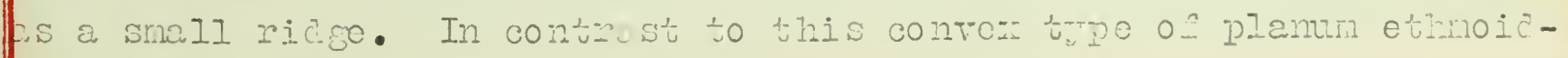





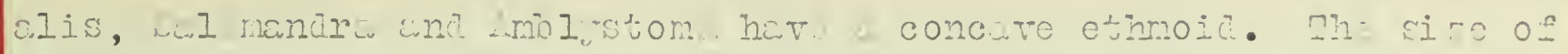

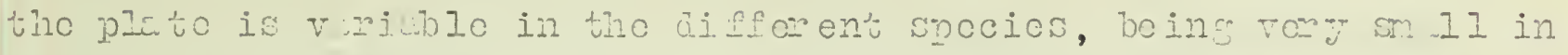

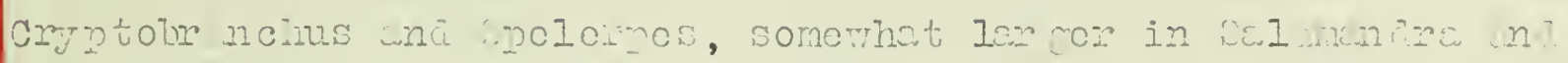

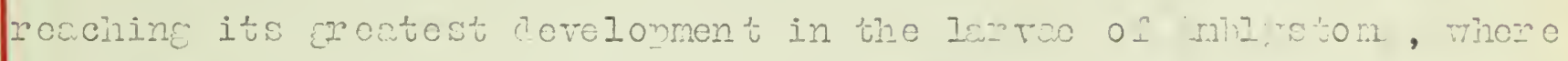

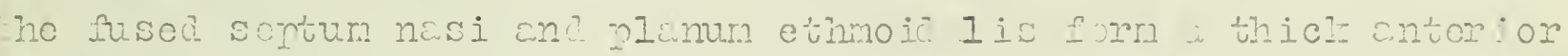

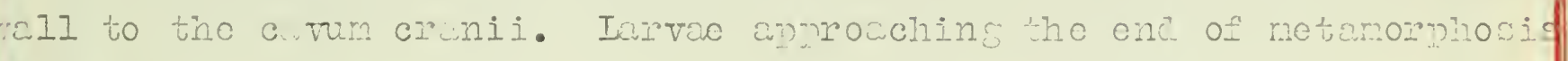

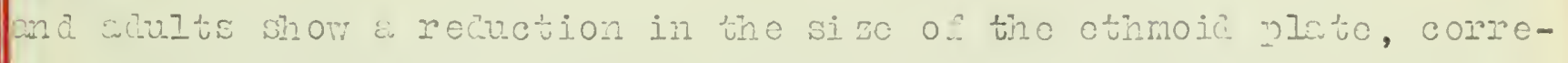

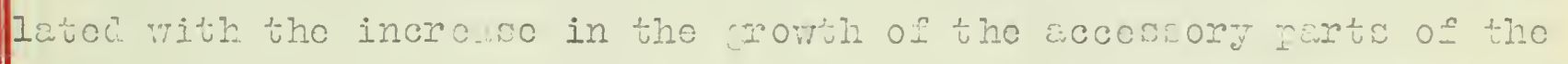

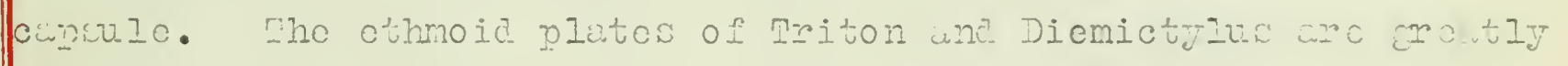
folivecd in both Isur vand wiult and cro vniquo in their posto ion position in relution to tho other cungular stuctures.

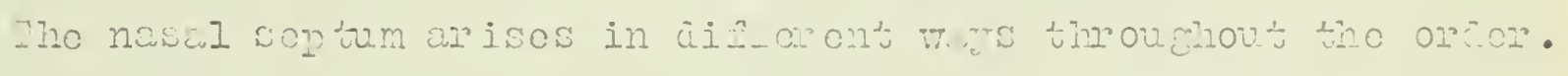

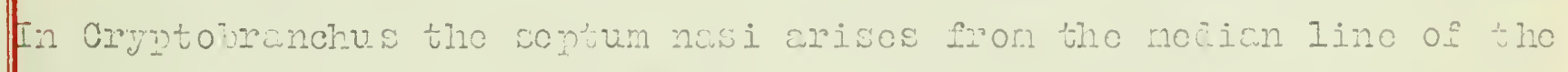

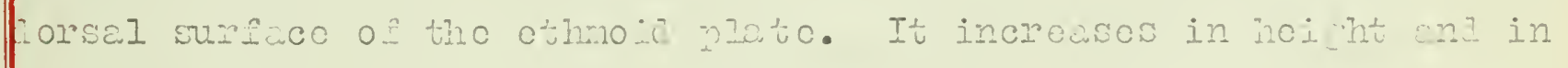

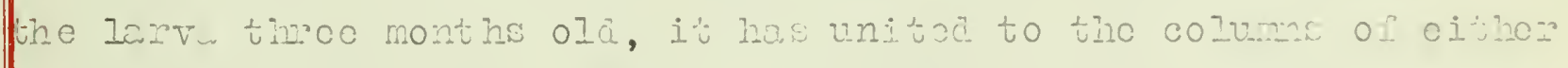

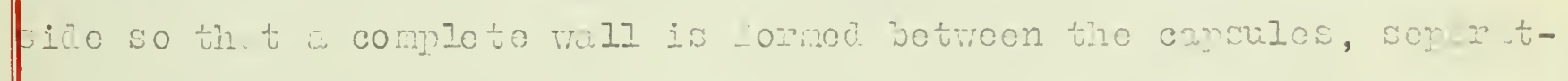

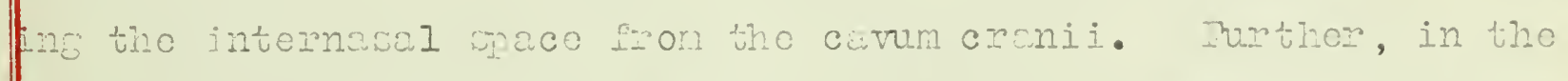

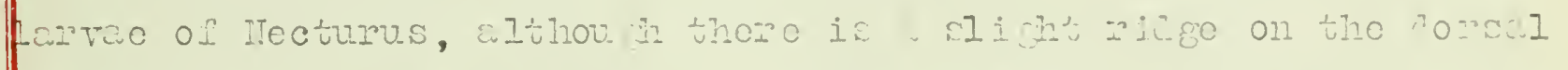

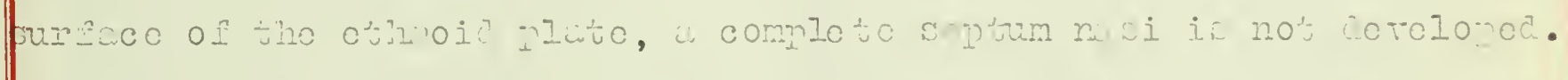

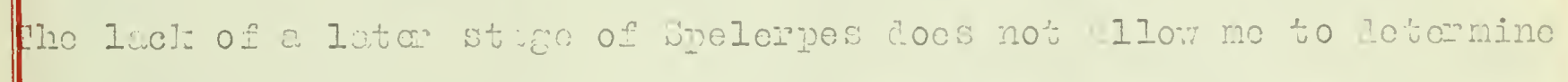

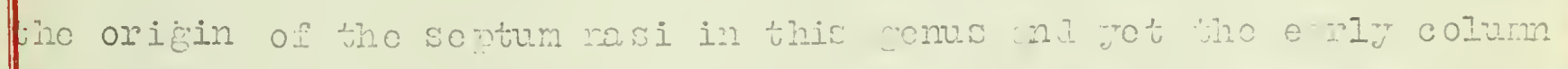

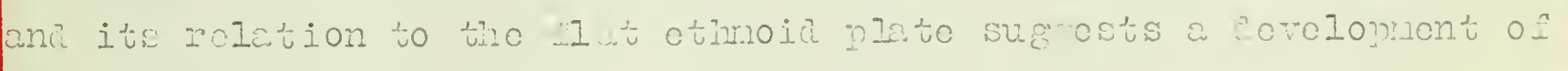

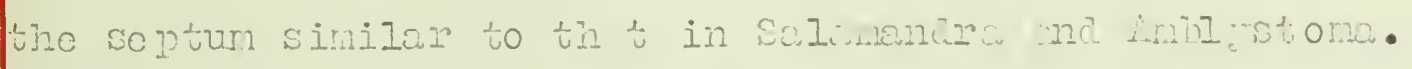

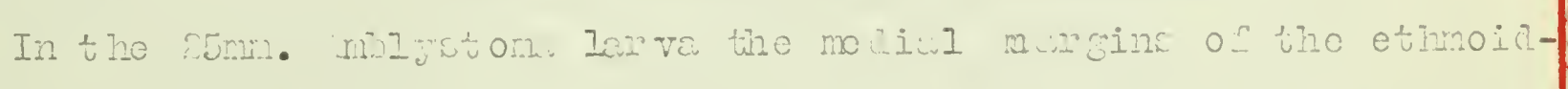

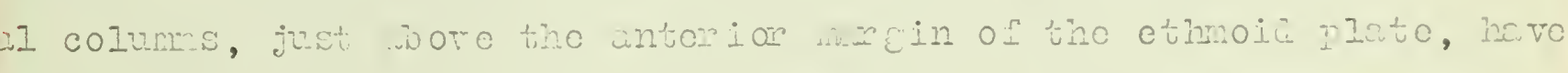

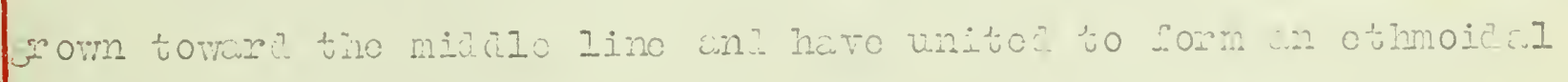

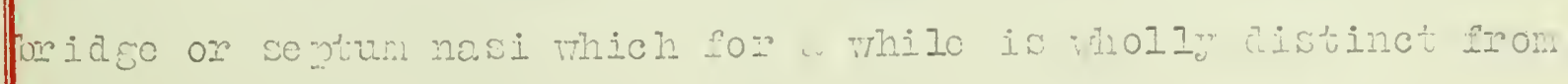

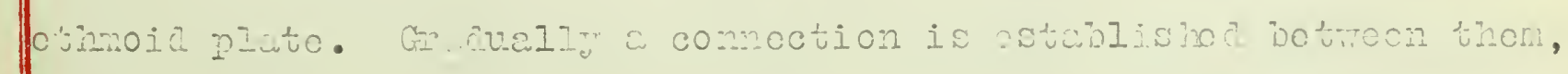





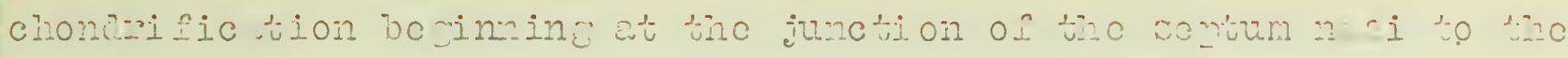

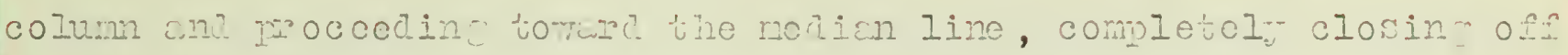

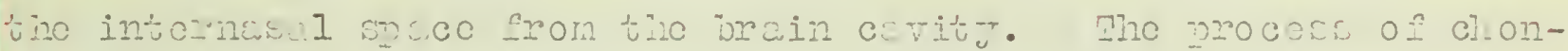

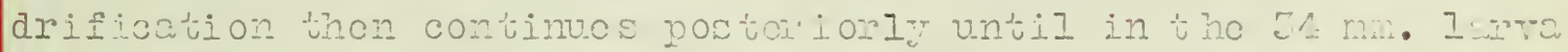

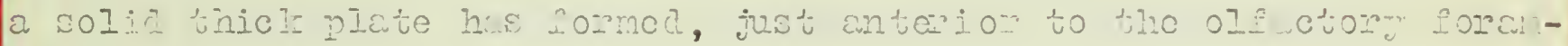
ins.

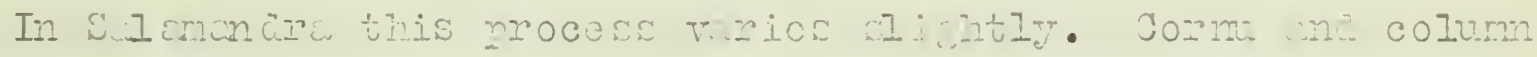
iro connectod in funt and then tho nes I sentum is fomod by a

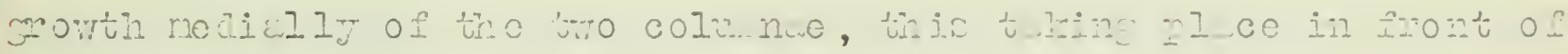

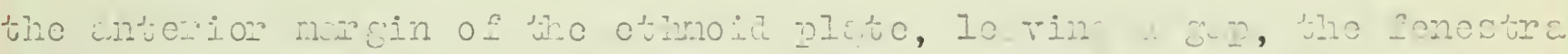

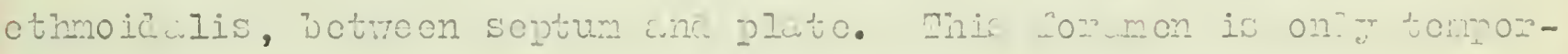

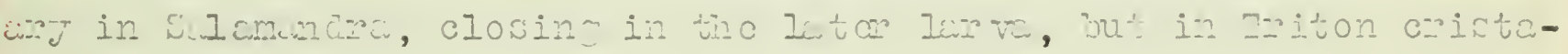

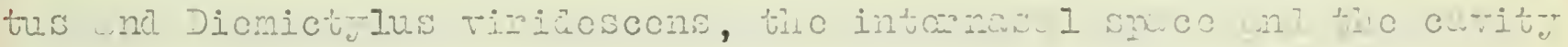

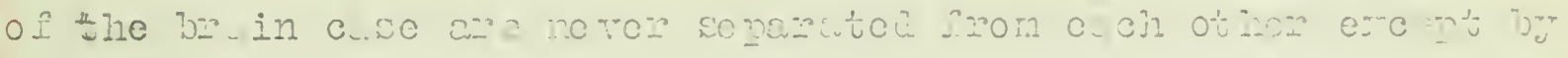

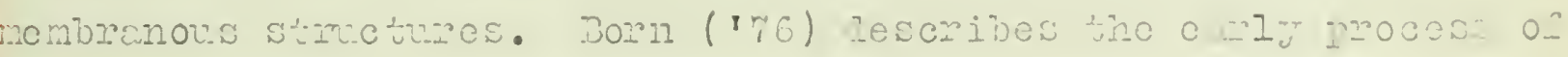

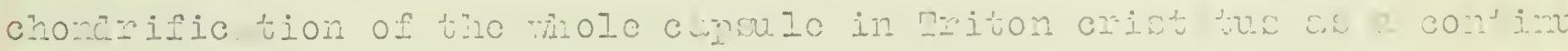

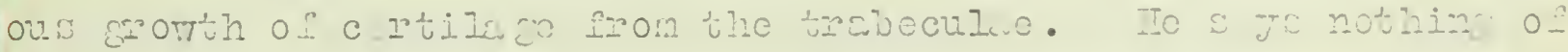

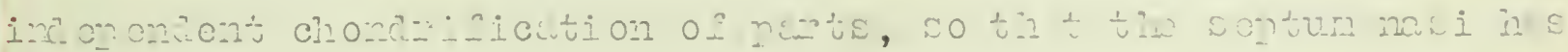

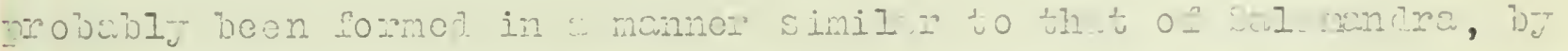

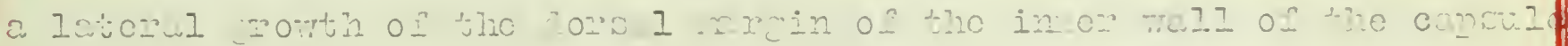

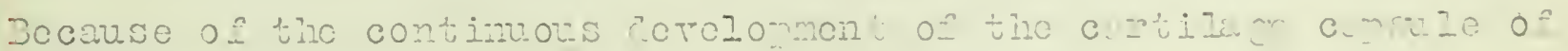

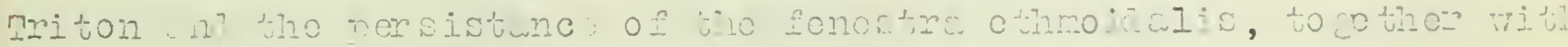

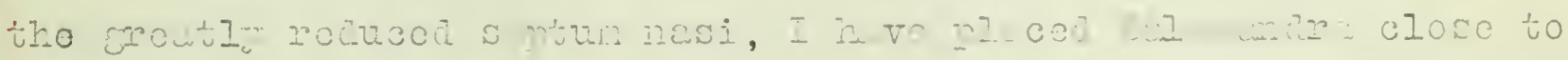

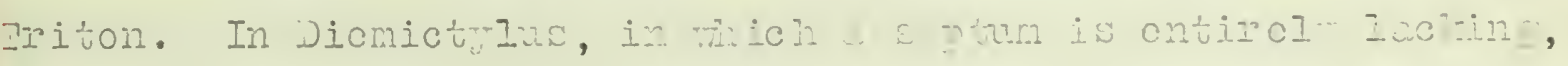

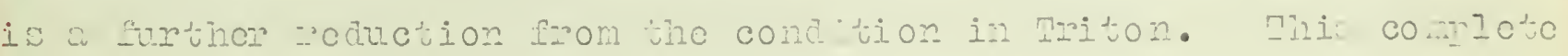

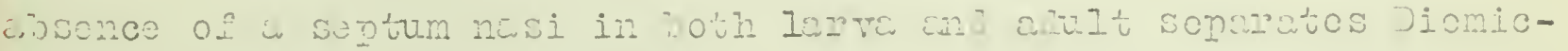

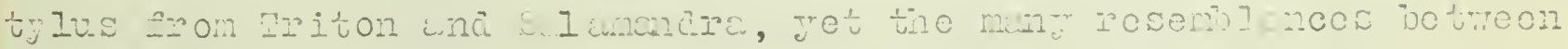
the cavsules of thesc cunimals wovle inite te a close rolciononsin 



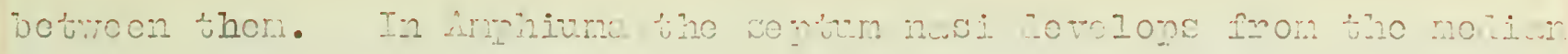

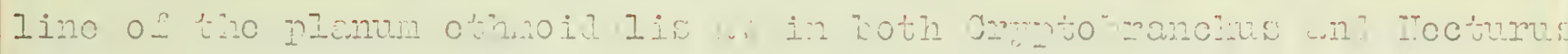

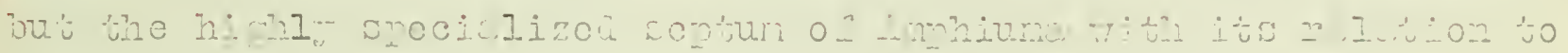

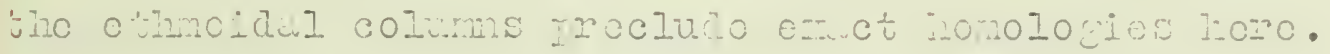

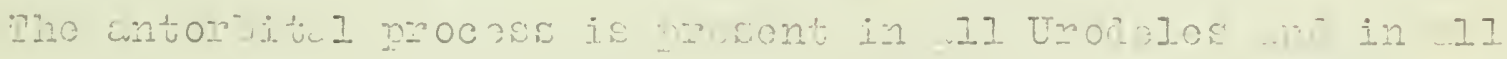

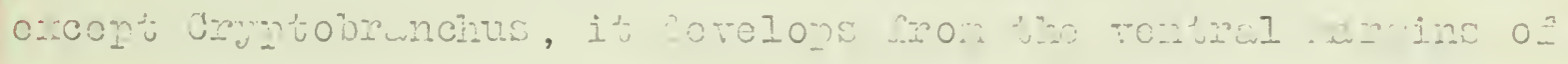

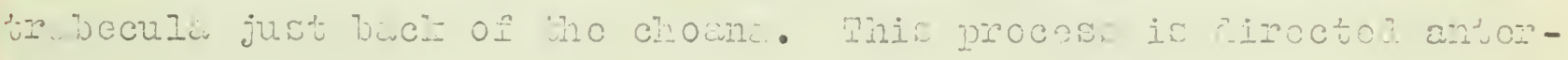

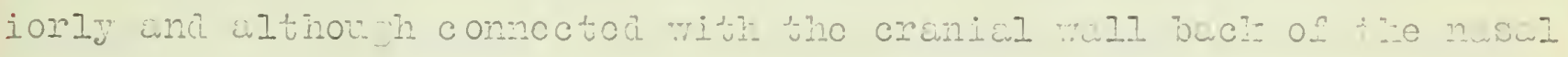

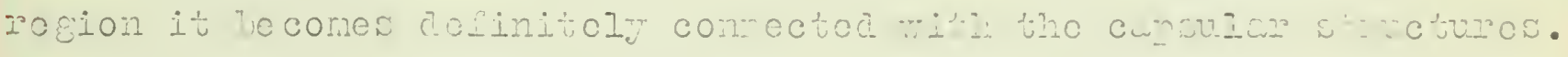

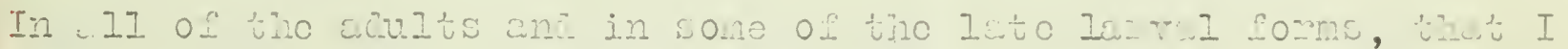

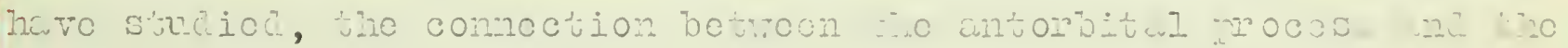

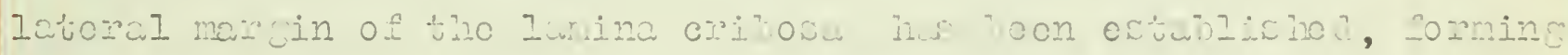

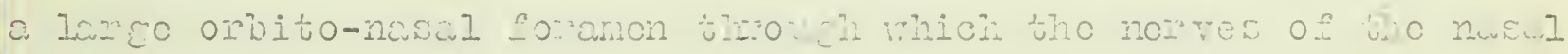

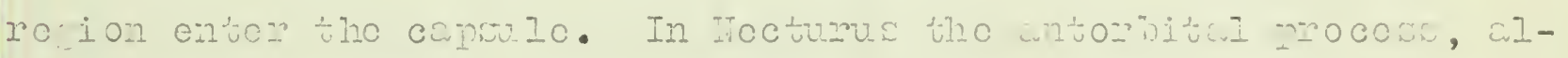

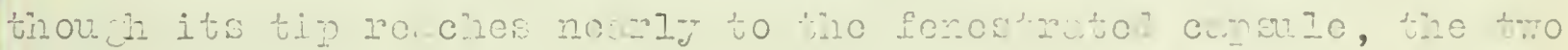
notor unito.

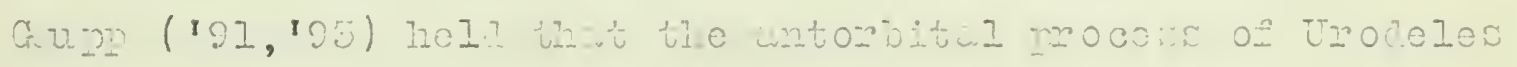

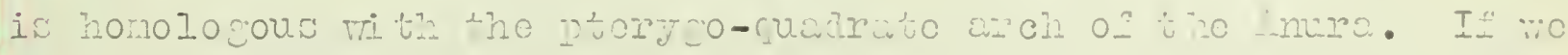

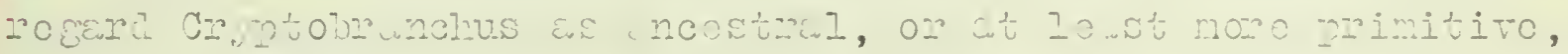

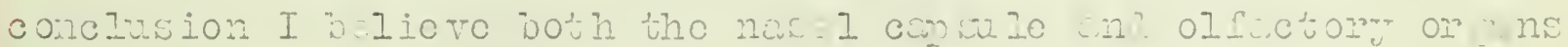

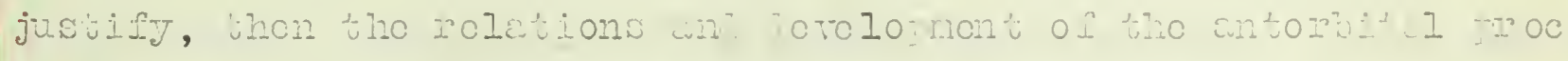

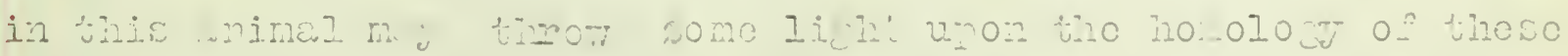

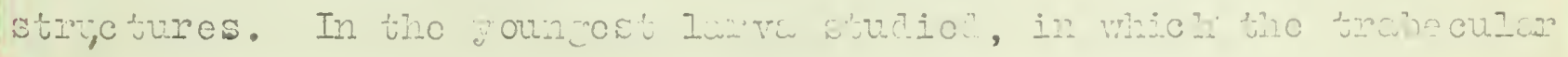

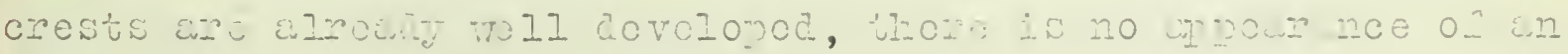

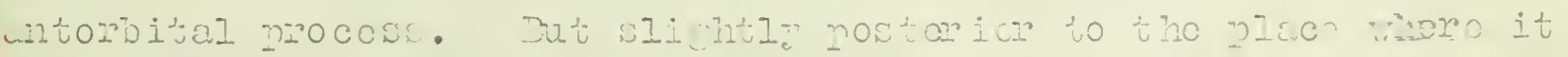

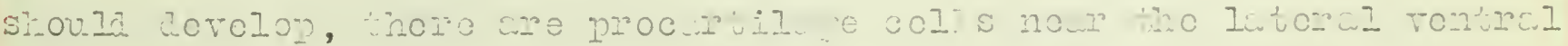

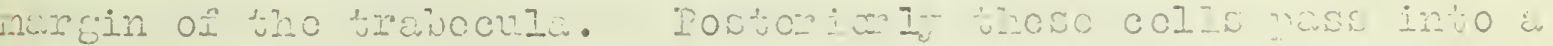

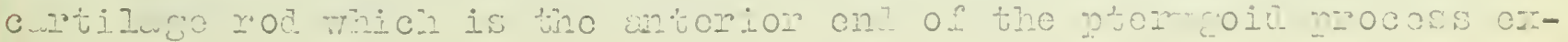





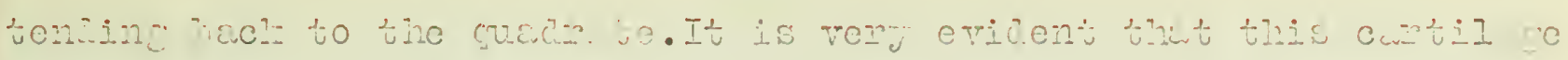

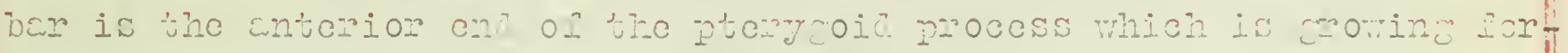
rard into the nasul re ion. In the later stace itu vinitos to the trabconla in the rogion whore the winomitul posos occurs in the

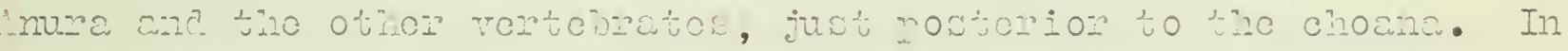

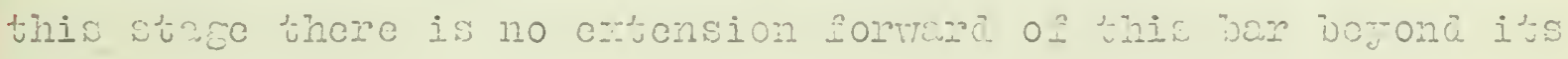

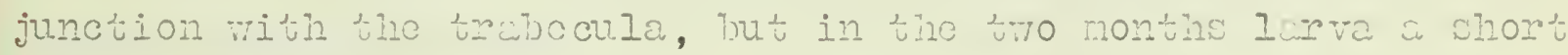

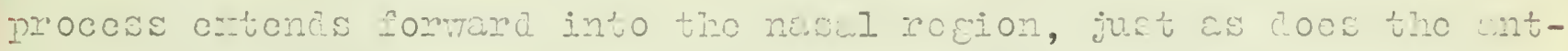

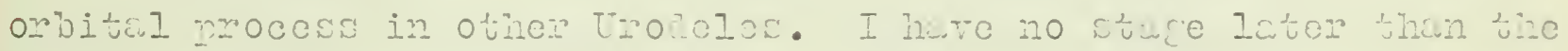

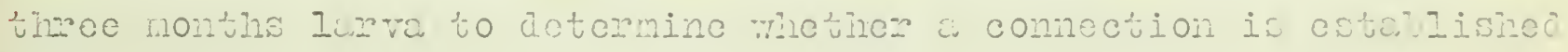

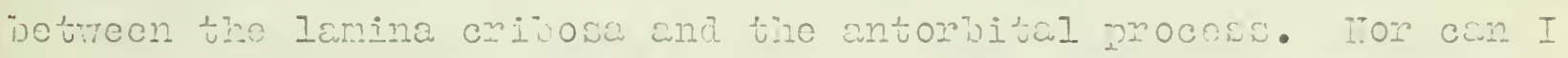

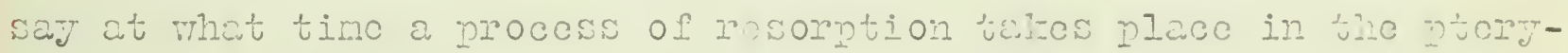

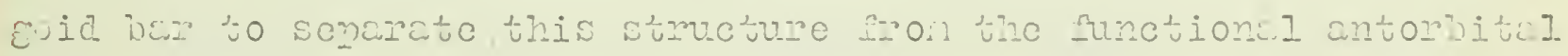

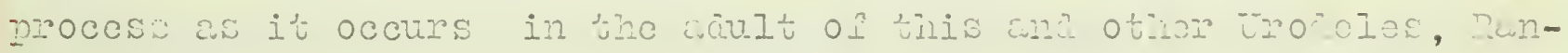
orion c:zcoteci.

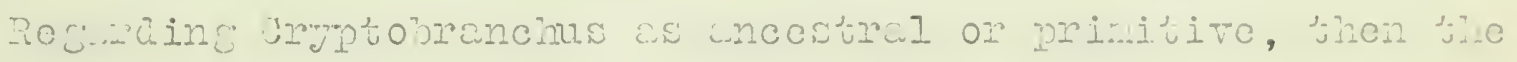

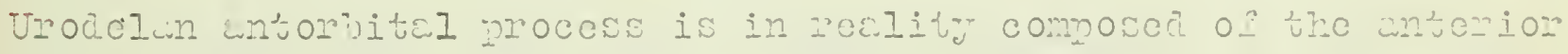

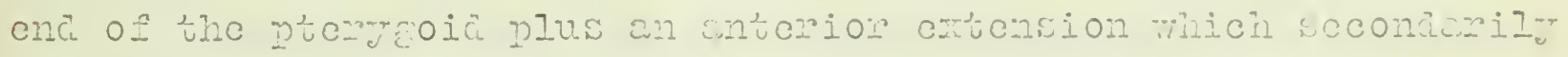

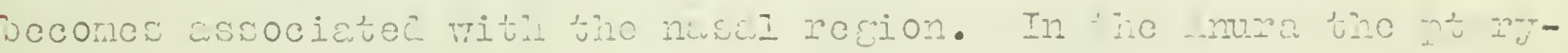

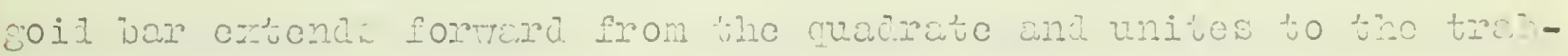

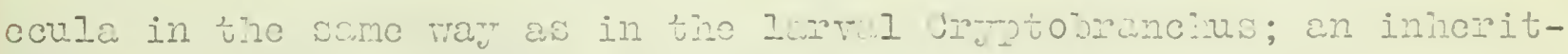

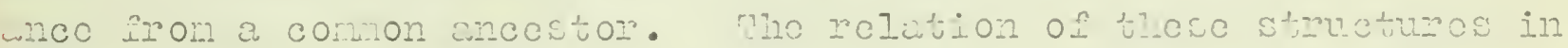

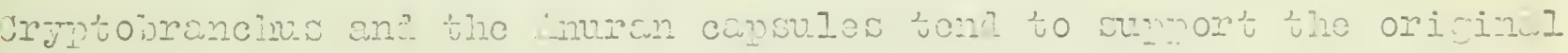

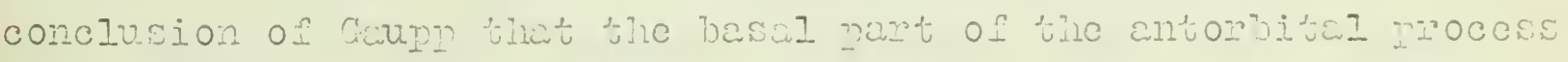

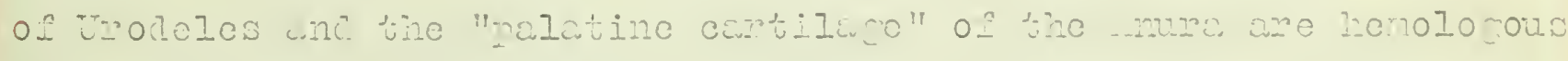

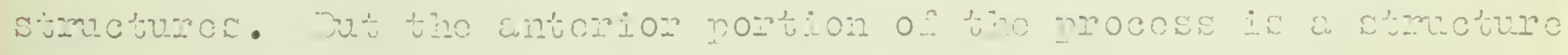

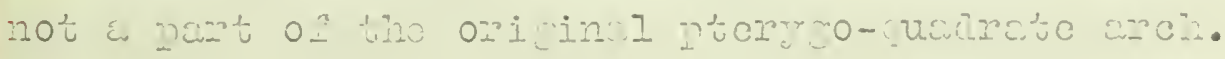

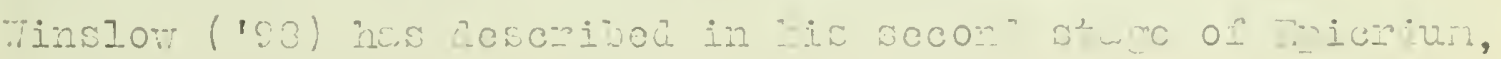





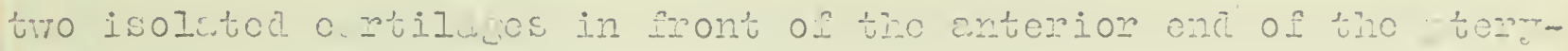

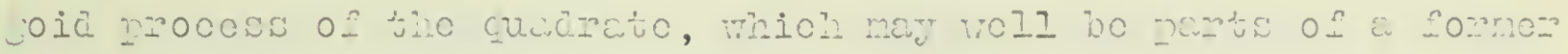

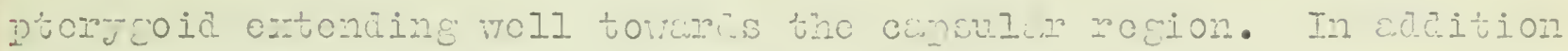

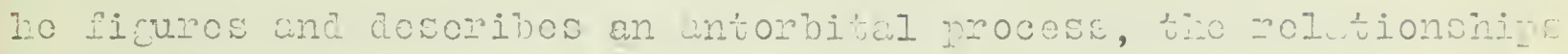

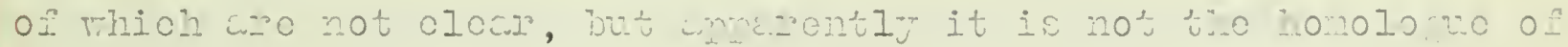

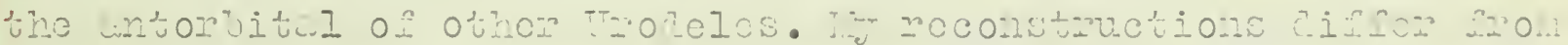
his in soropeci rospeots.

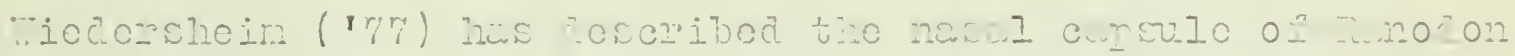

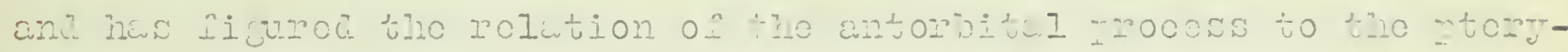

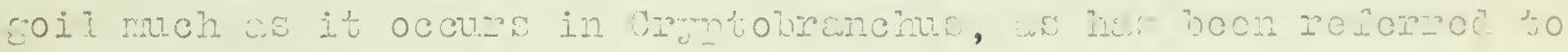

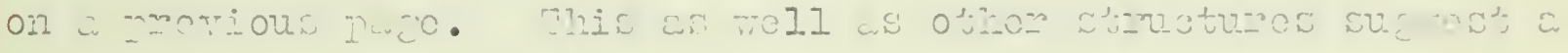

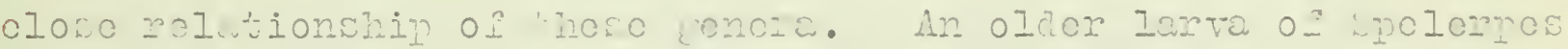

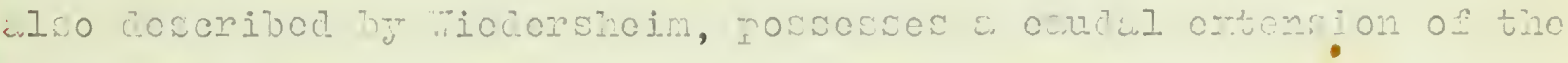

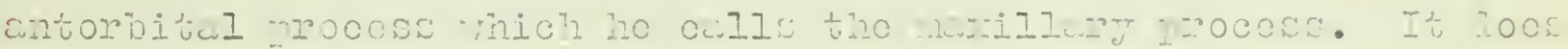

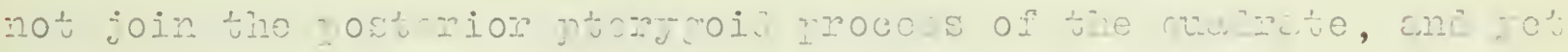

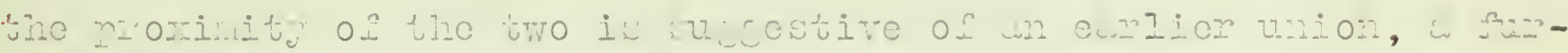

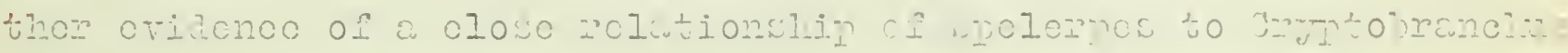

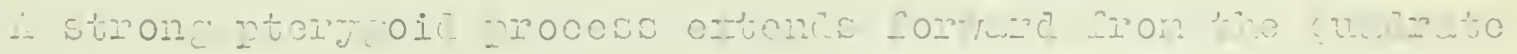

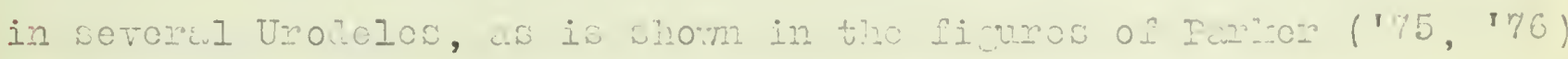

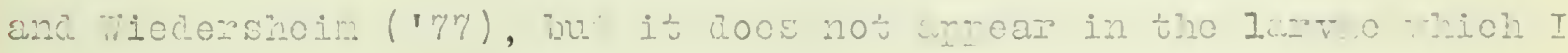

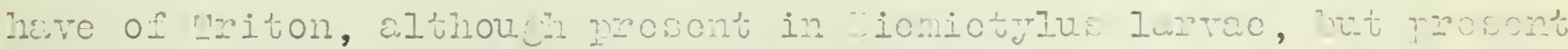

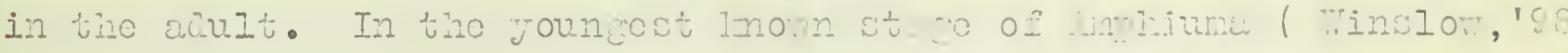

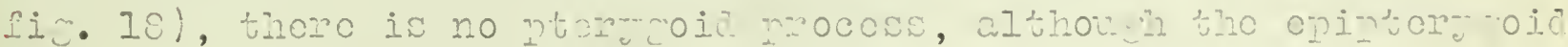
is monont wa in all trocolos. In a lutor staco, the mocoss is

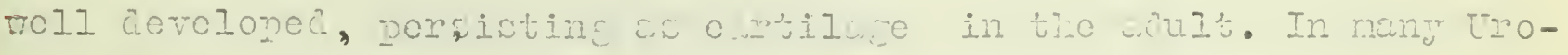

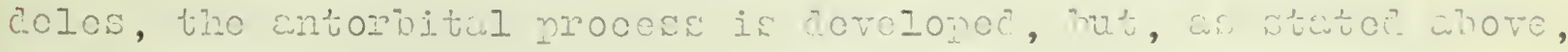

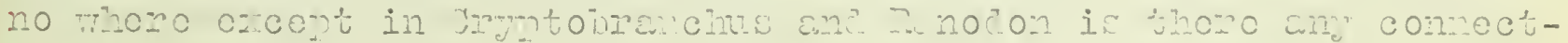

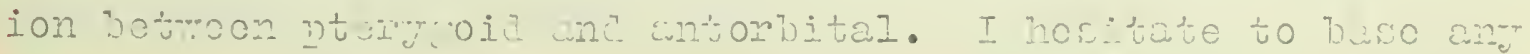





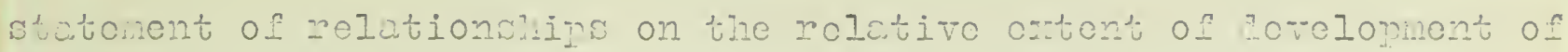

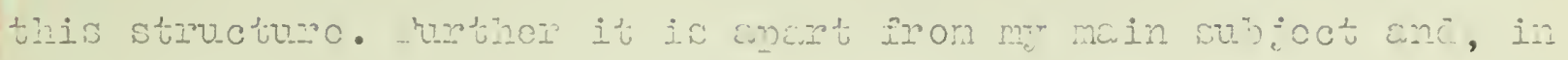

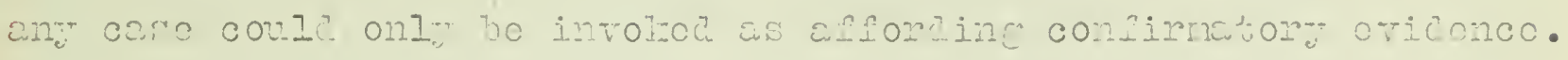

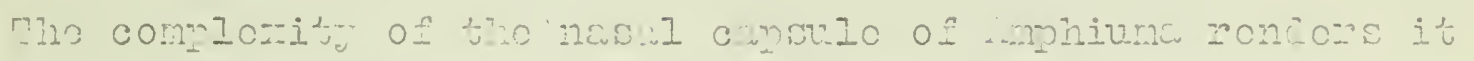

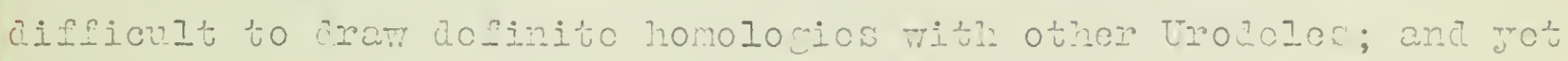

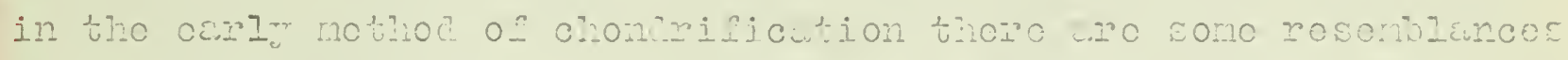

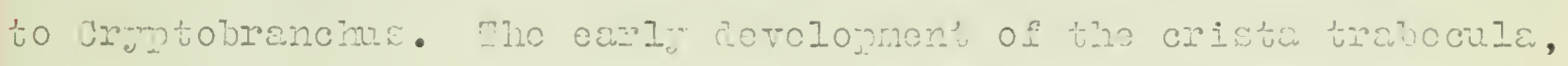

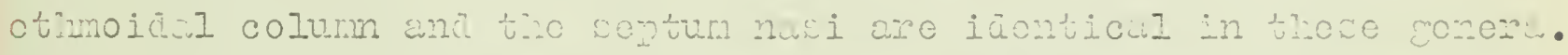

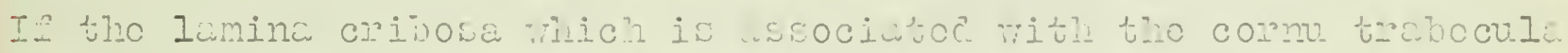

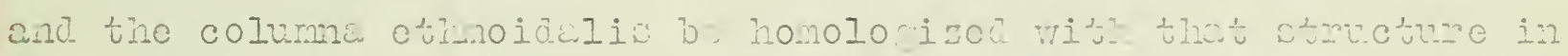

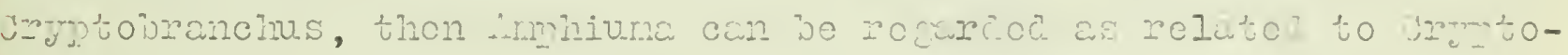

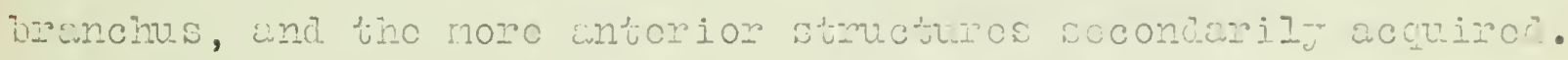

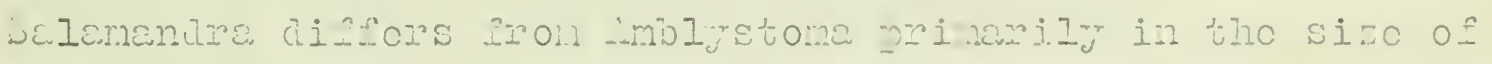

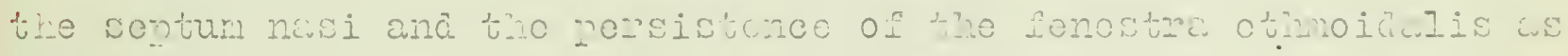

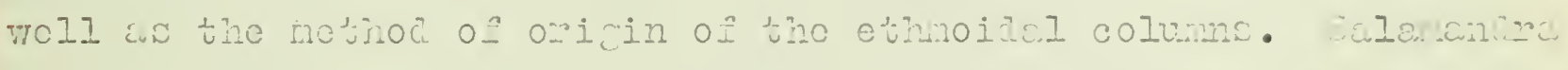

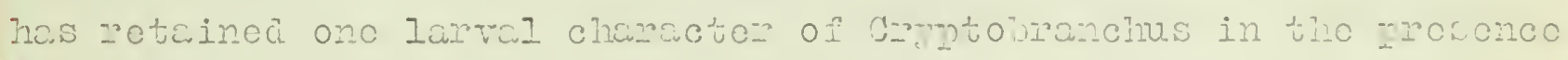

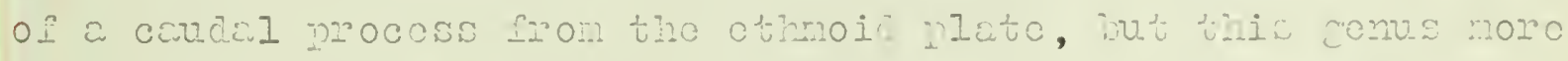

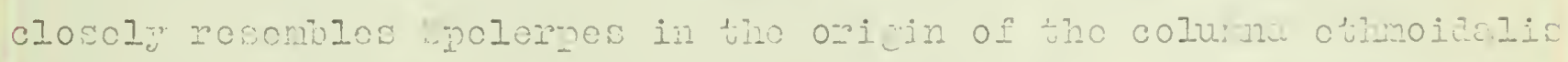

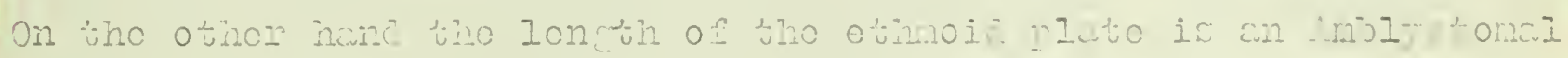

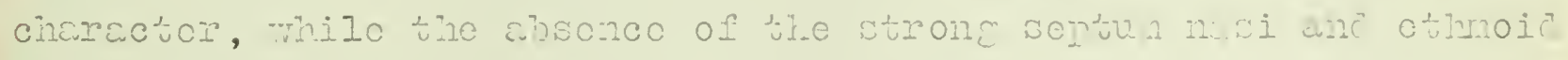

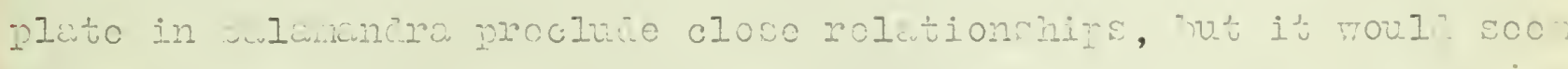

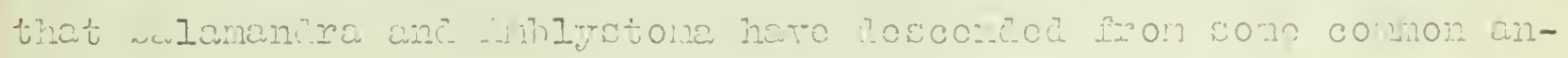
costor.

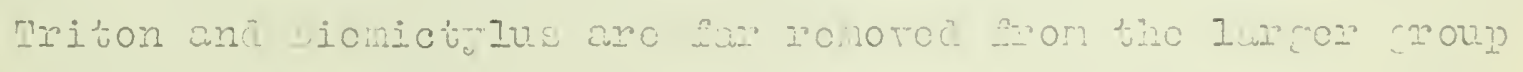

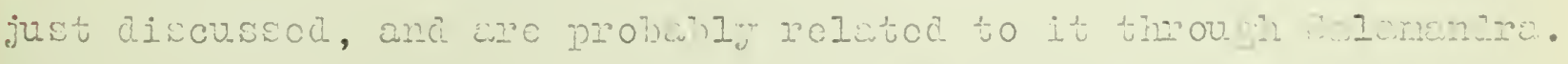

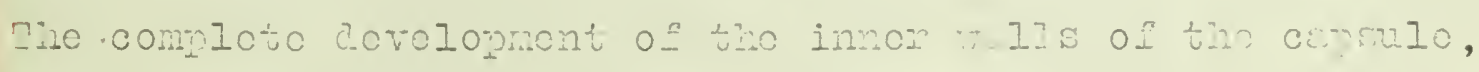

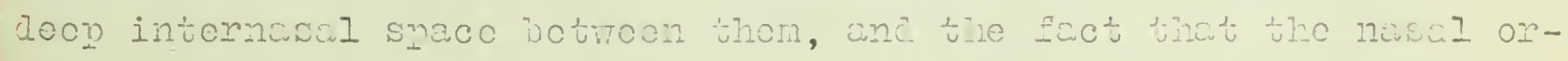

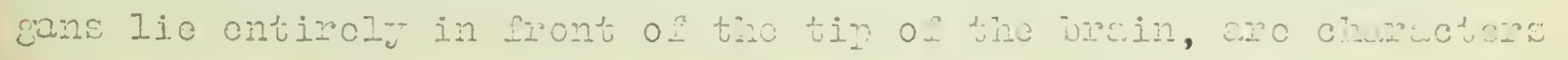





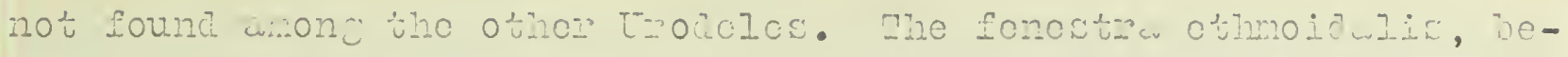

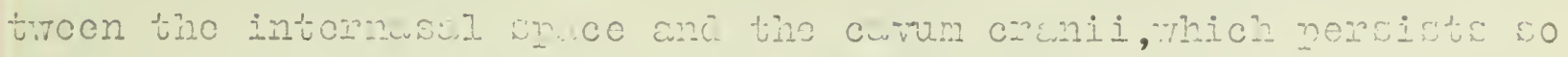

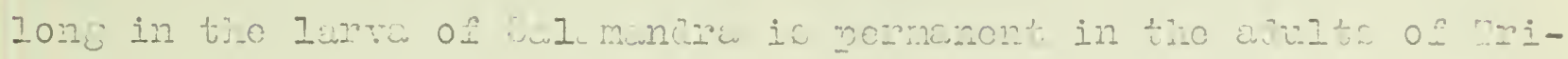

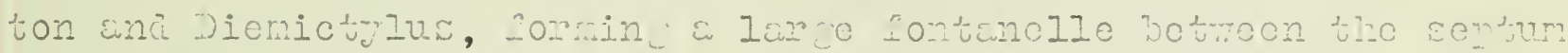
anj tho othmoid platue. In Diomictulus, tho comleso low of tho

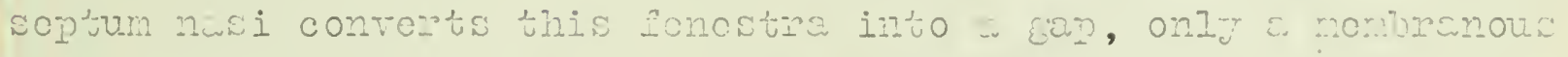

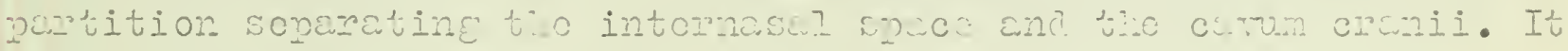

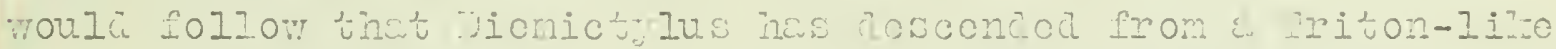

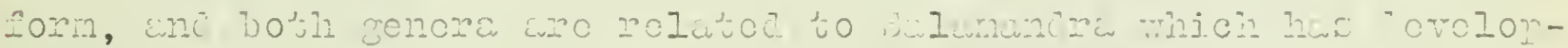

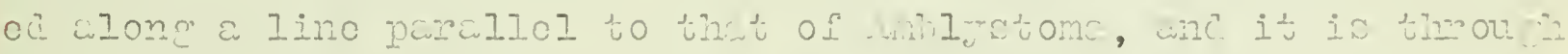

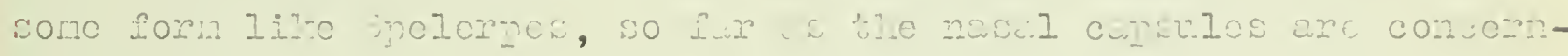

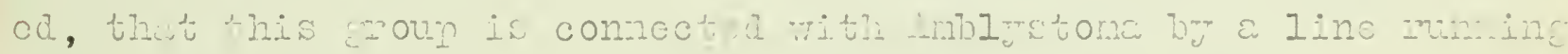

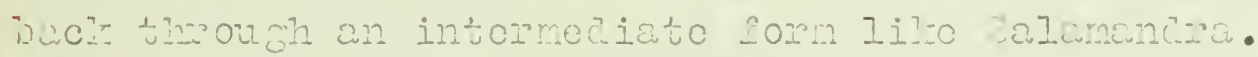

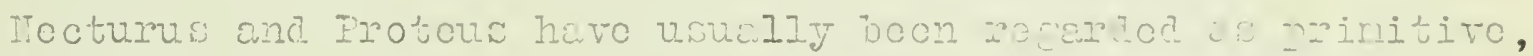

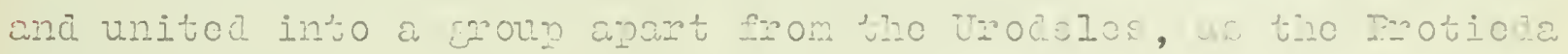

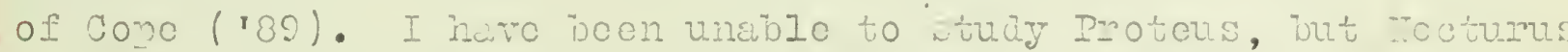

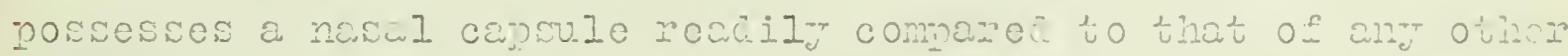

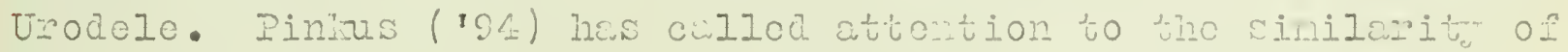

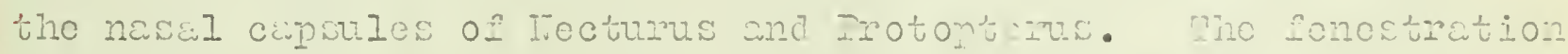

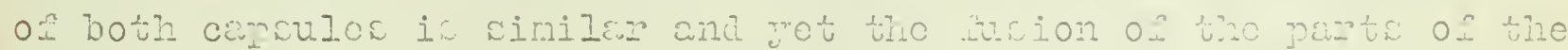

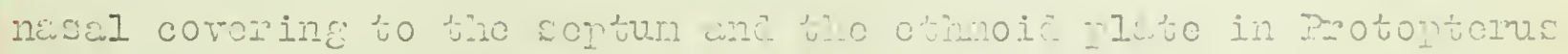

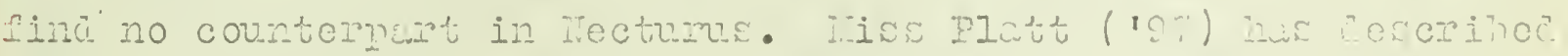

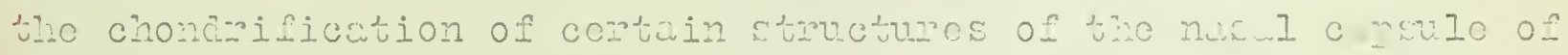
Iocturus, such cs the troboculum crosts, othoidcl plato, cne col-

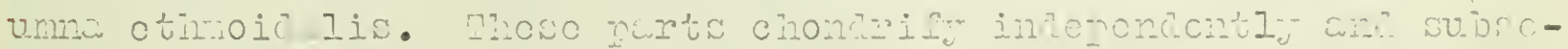
vonty unito to each othon, with sho oxcontion on tho othmoin I

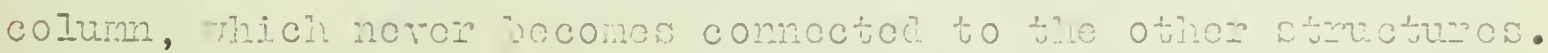

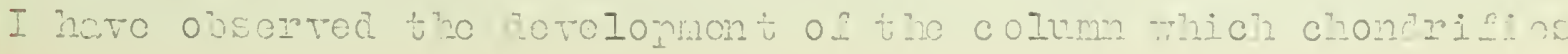





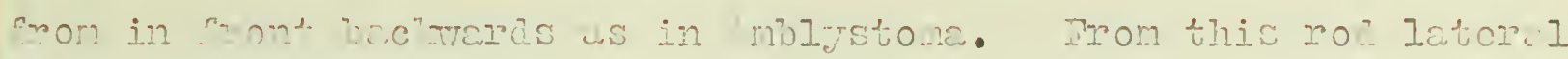

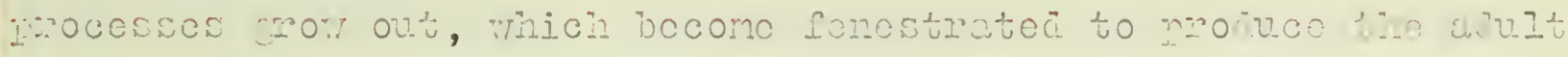

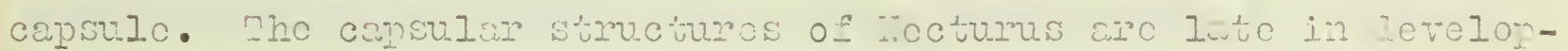

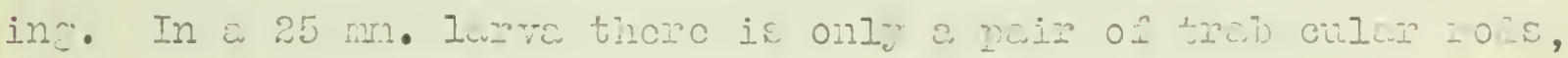

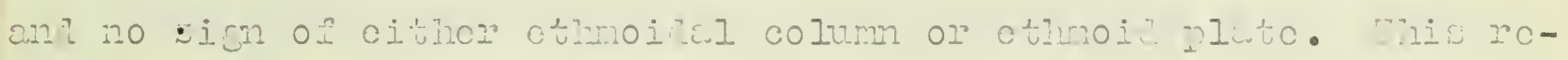

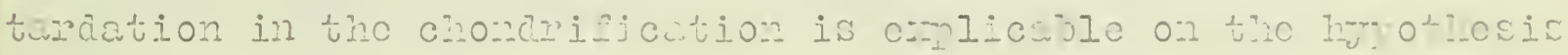
that Ircotume is a porstetont lusta.

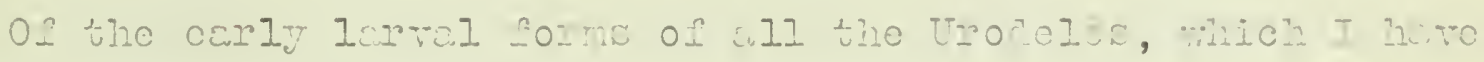

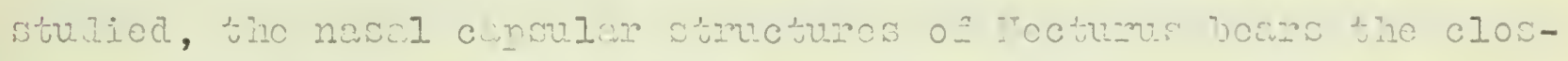

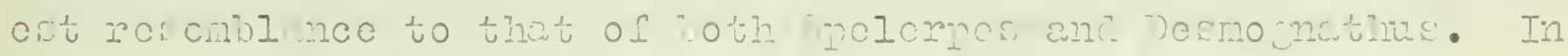

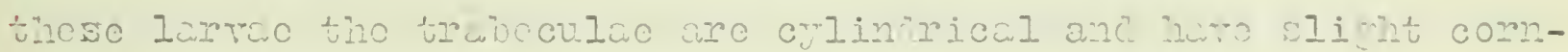

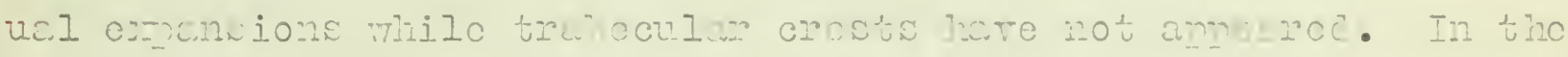

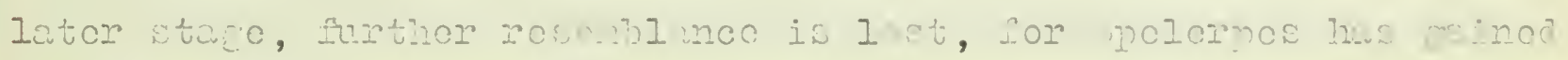

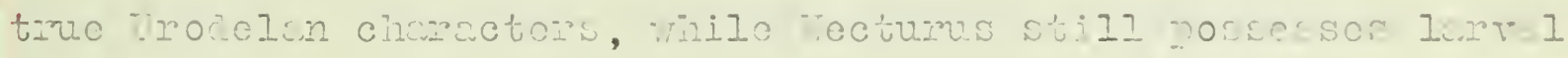
rolutions.

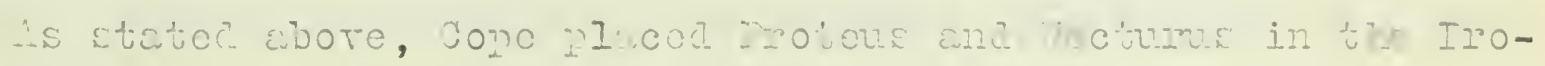

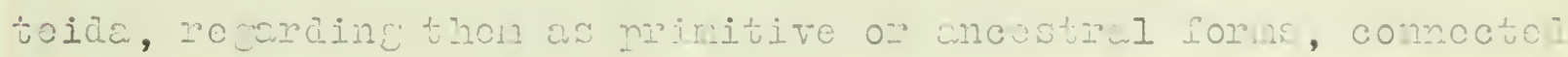

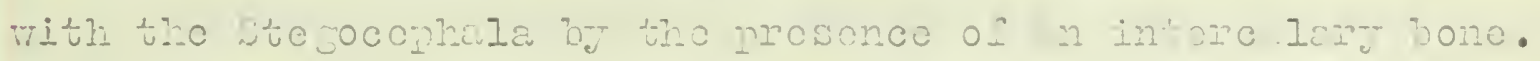

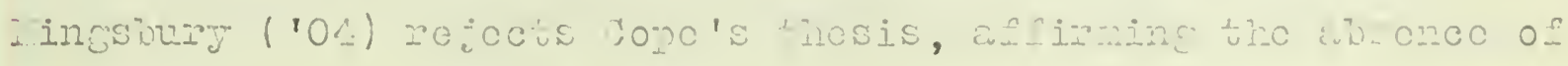

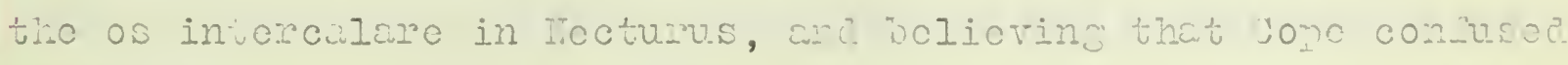

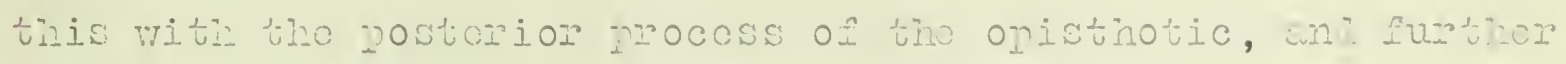

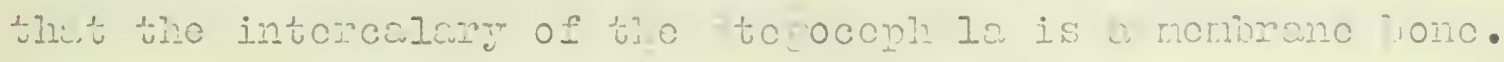

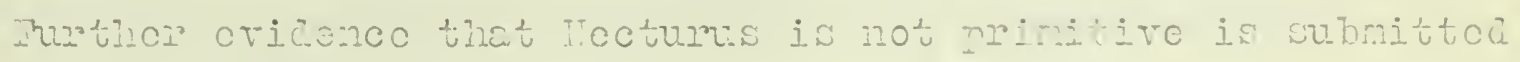

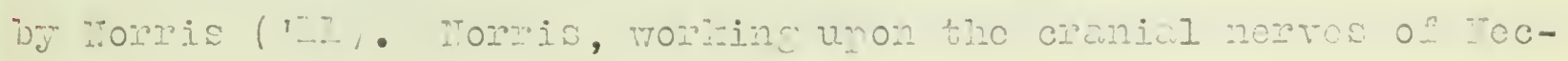

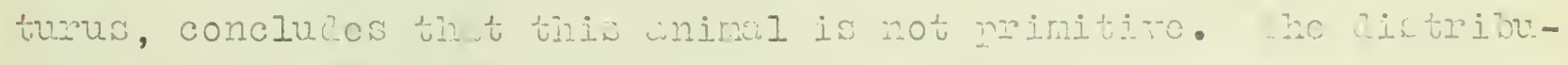
tion of the cronial nortos a poos in coteil wh thet of tro him

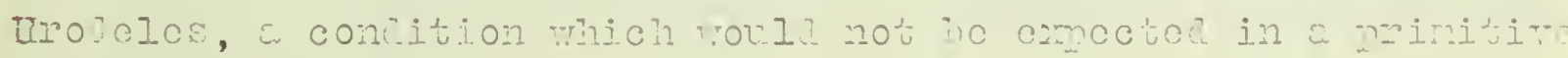





\section{2}

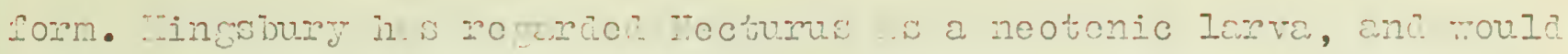

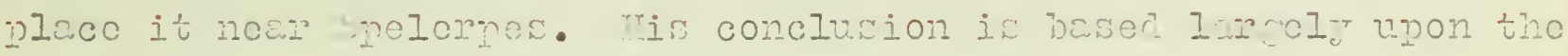

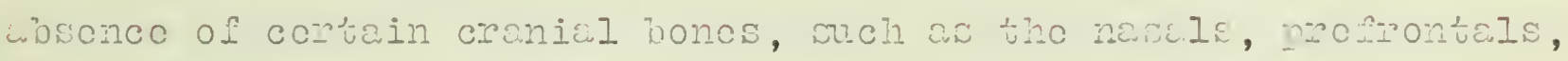

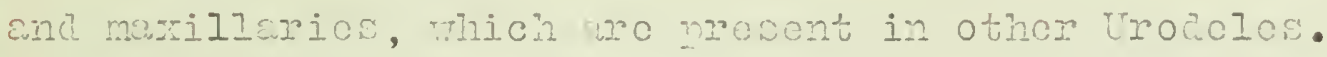

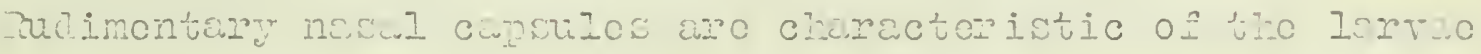

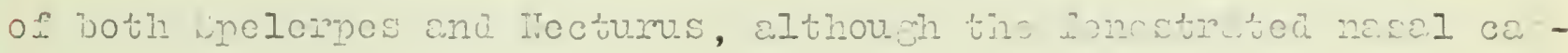

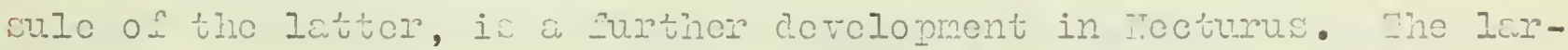

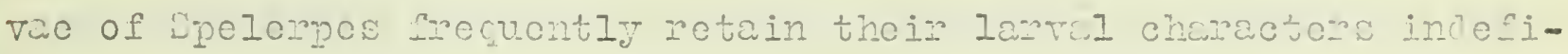

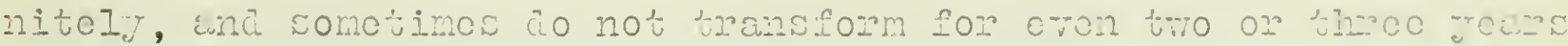
atter hatching, having attainod at this tino a lenctin of $60 \mathrm{~m}$.

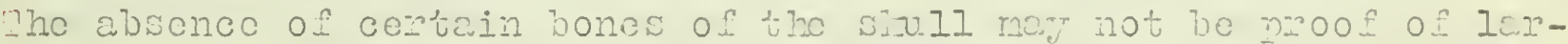

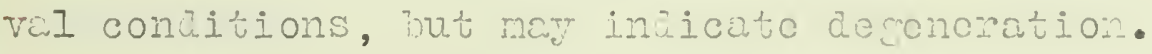

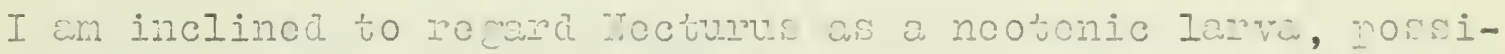

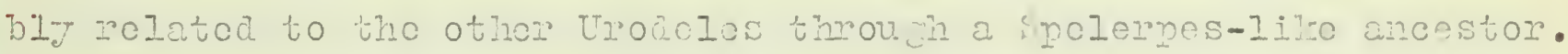

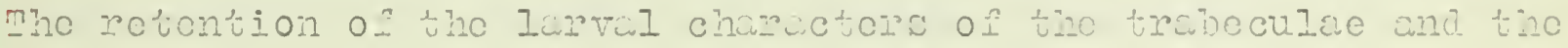
cthmoid plato can cortainly not bo rog med as ancostral; nom cun

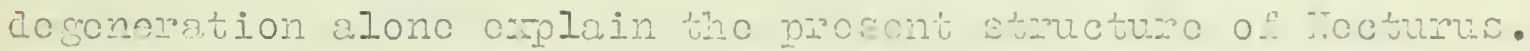

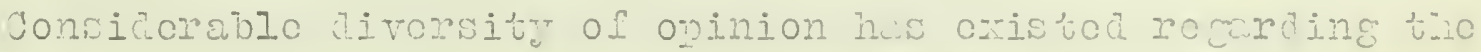

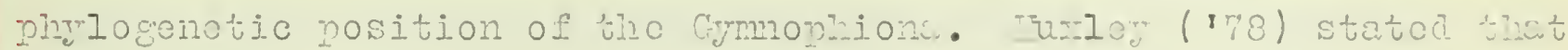
thenc Was not tho slifhtest incication of any arJominction to ei-

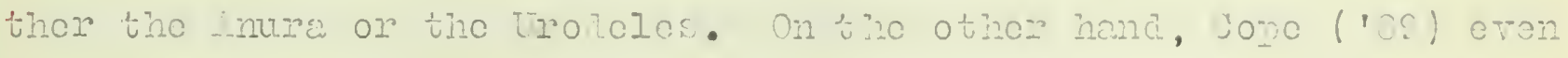

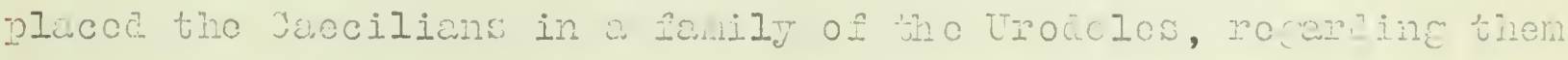

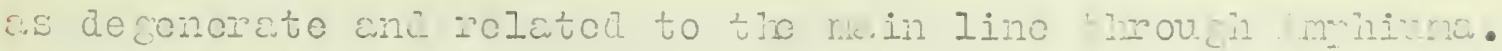

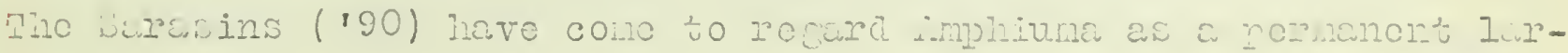

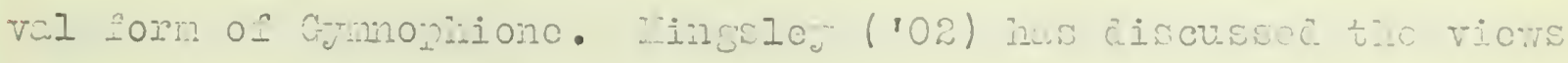

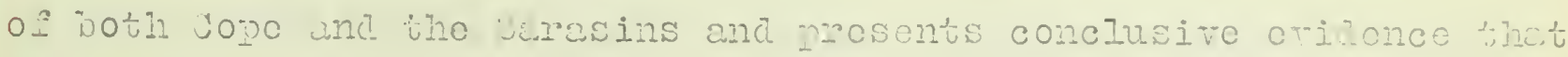

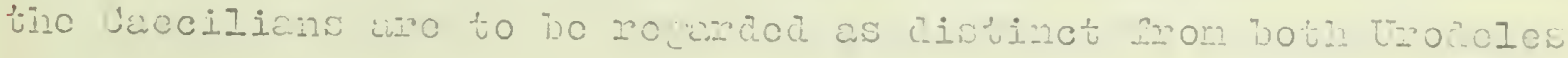

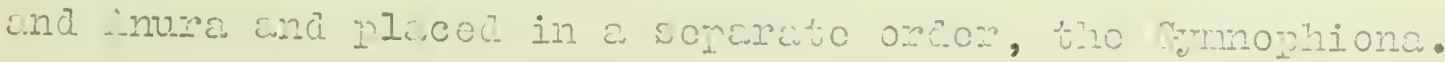





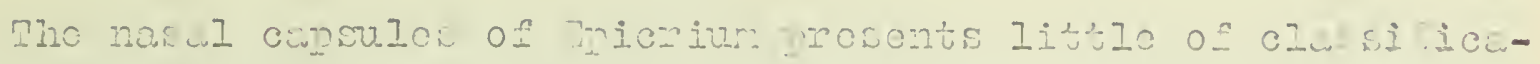

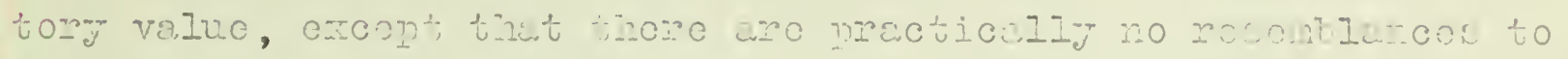

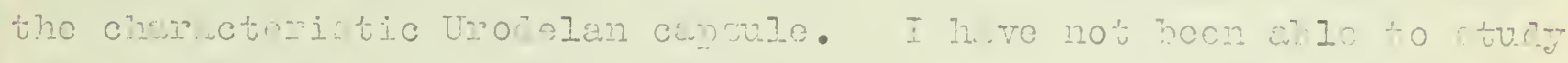

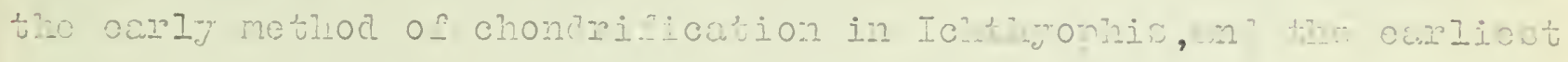

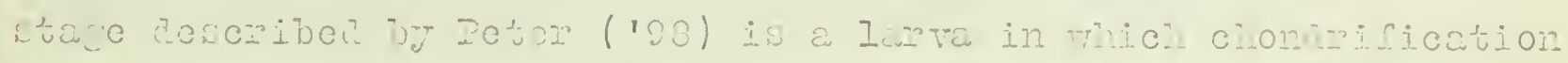

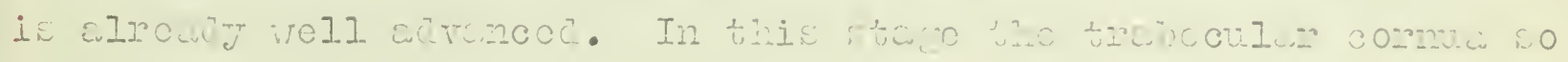

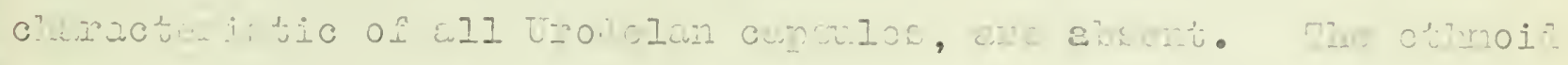

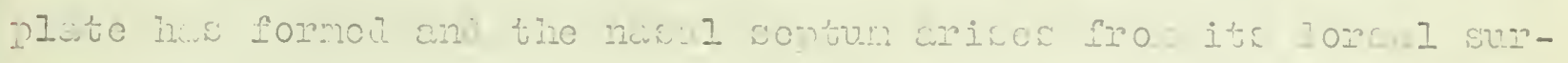

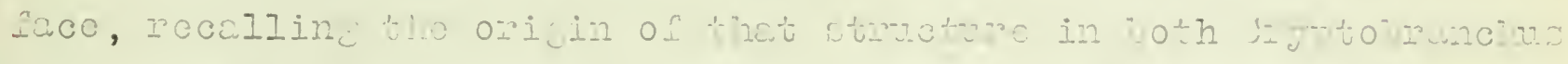

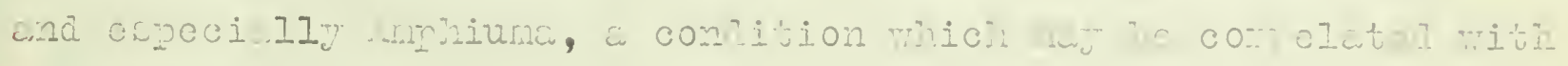

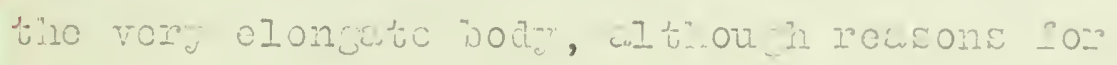
2ot oritient.

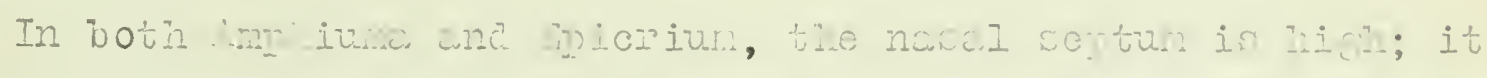

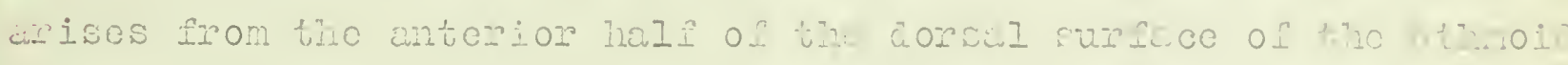

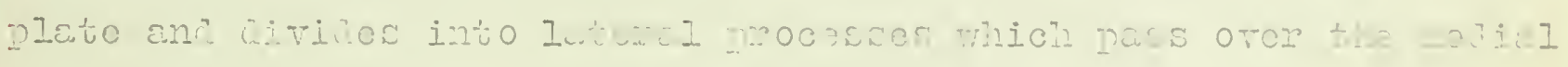

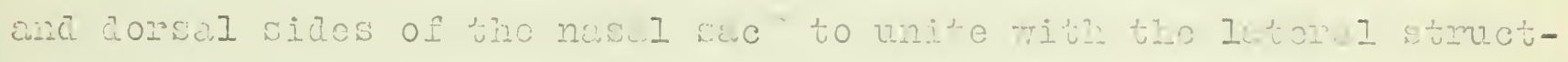

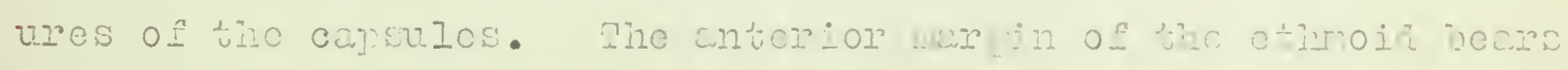

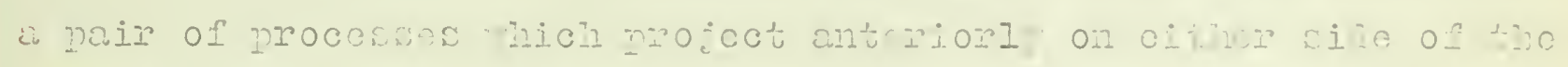

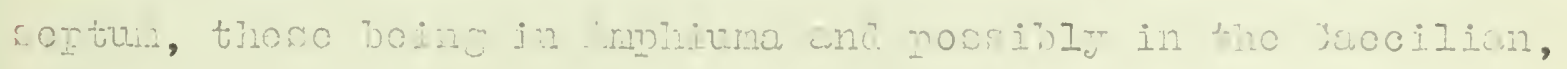

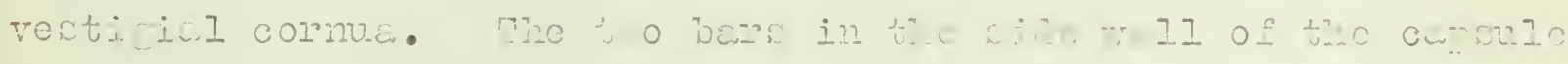

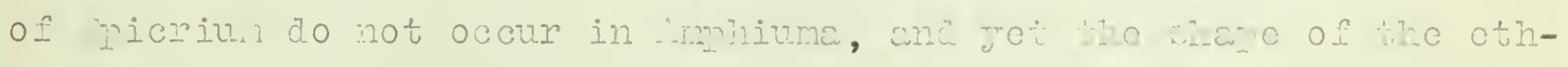

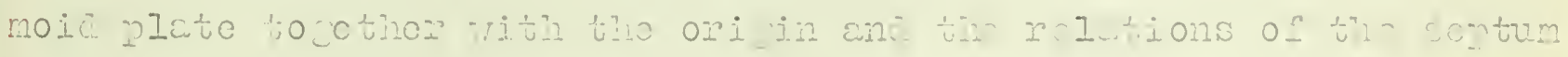

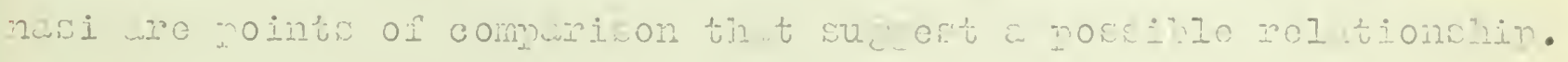

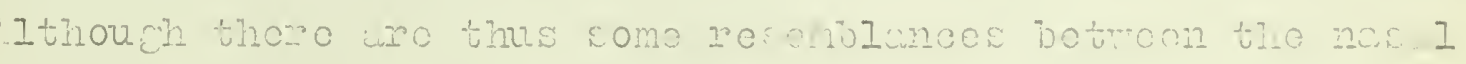

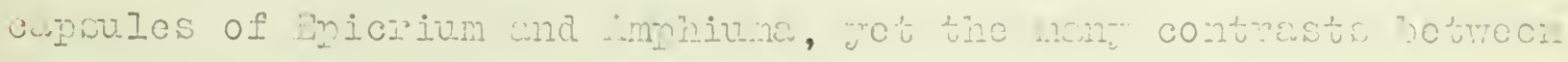

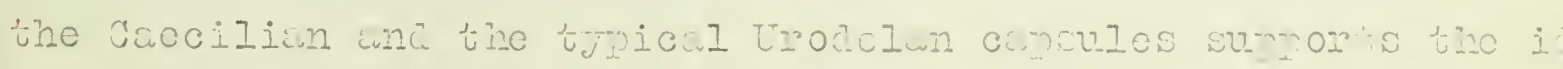

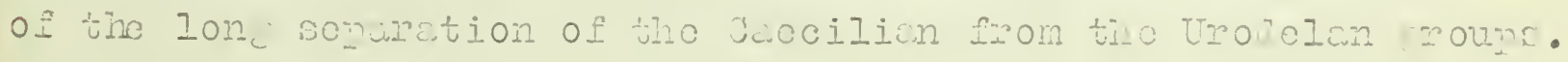





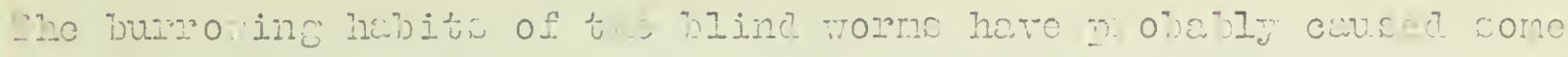

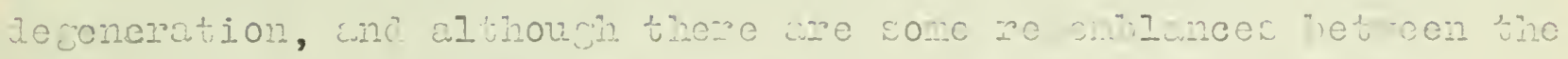

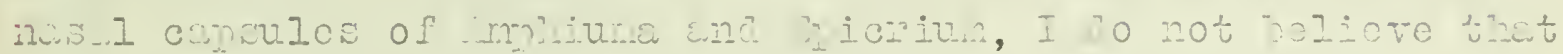

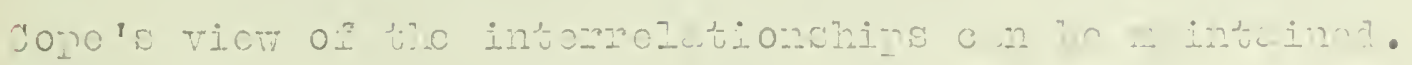





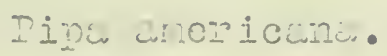

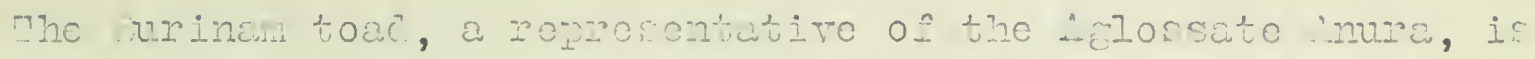

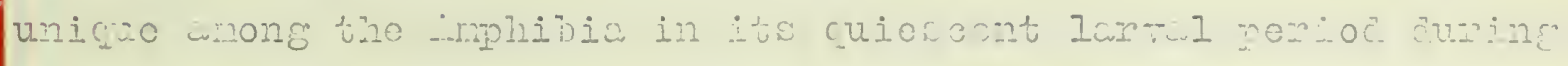

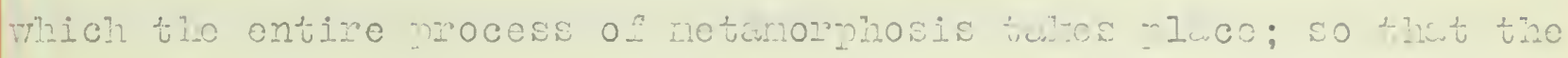

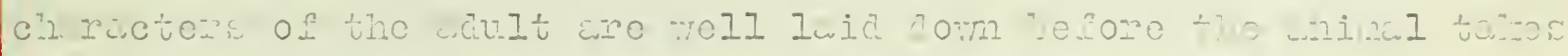

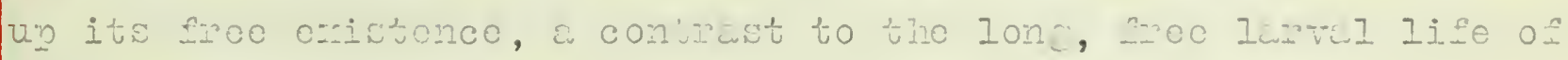

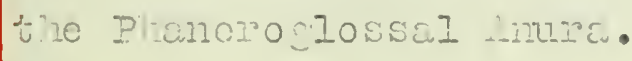

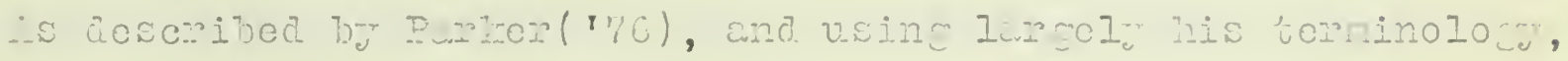

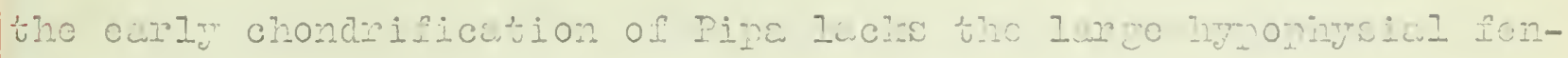

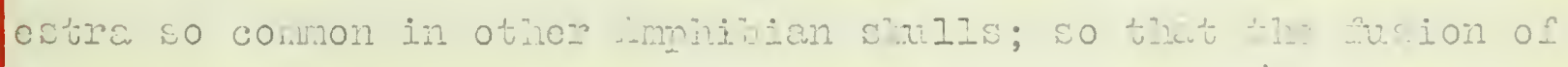

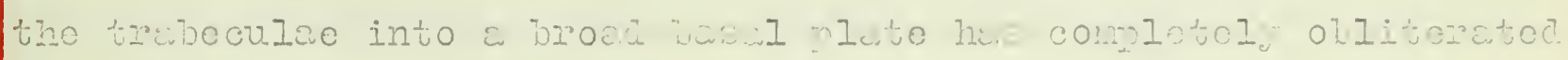

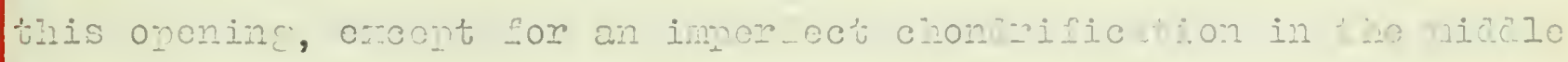

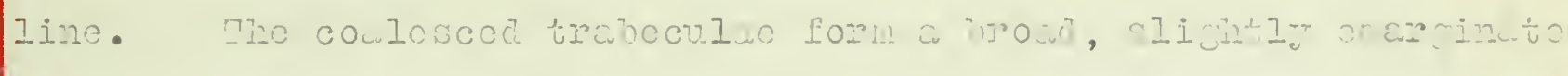

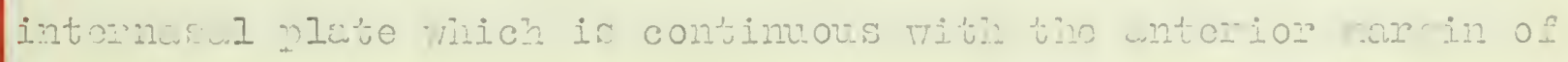

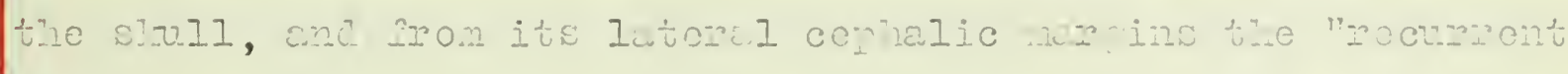

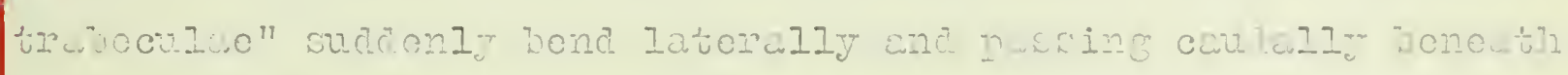

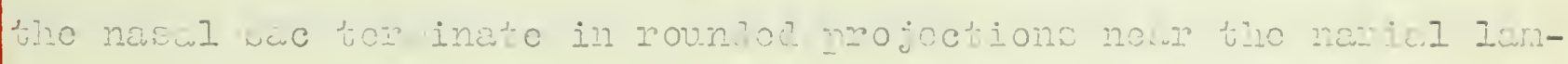

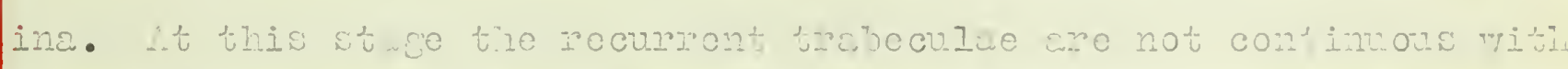

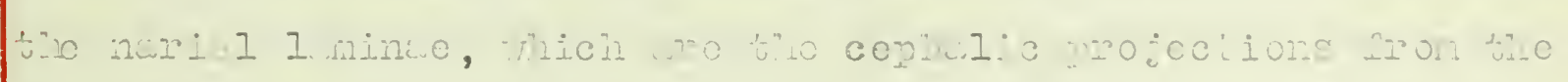

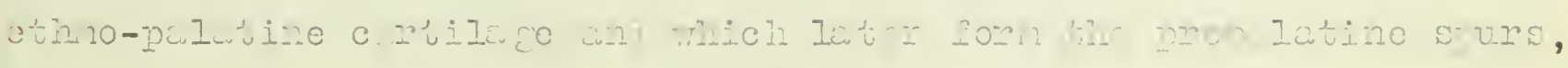

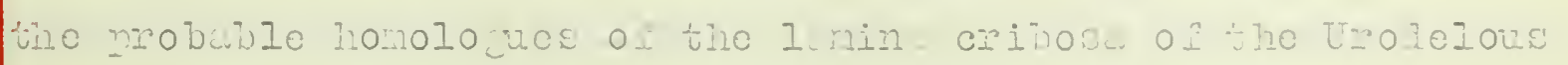
$\cos 10$

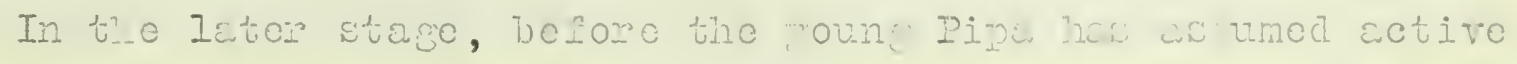

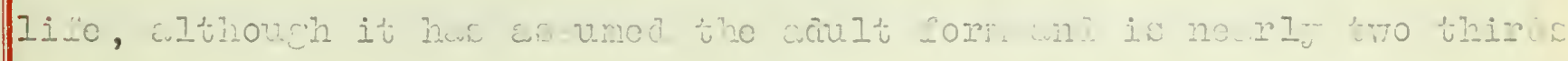

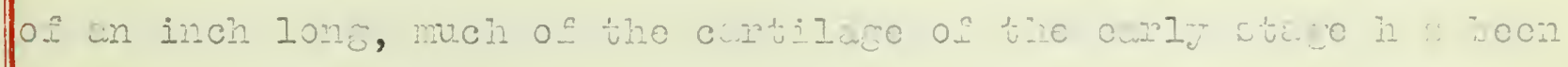

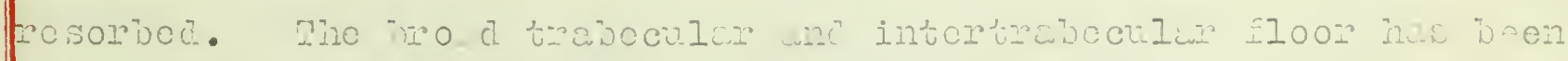

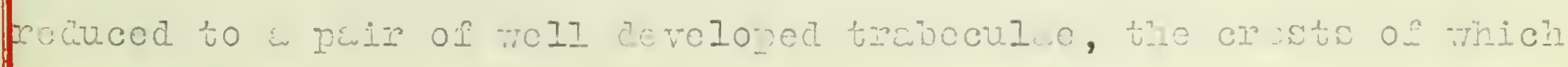

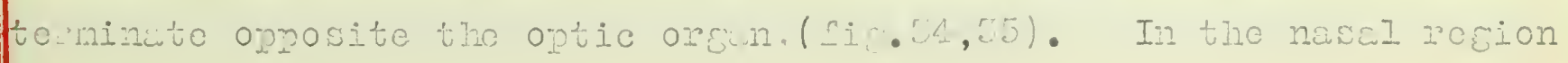





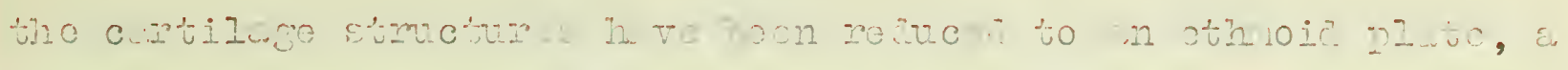

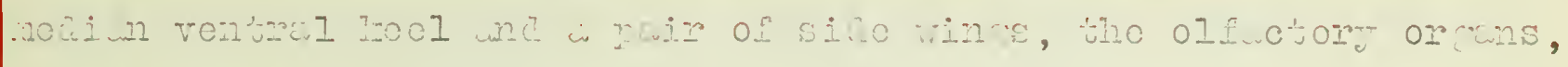

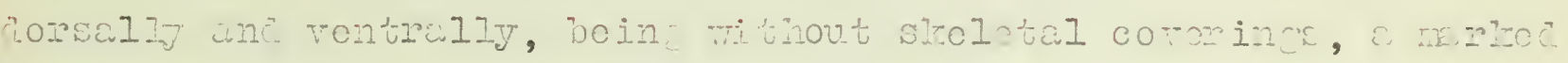

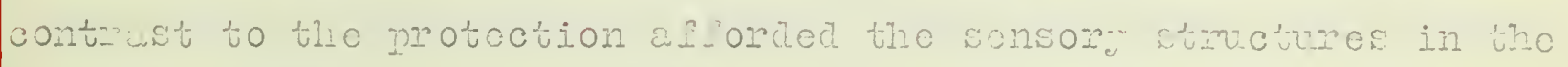
Phancro-lossa doscrived bolon.

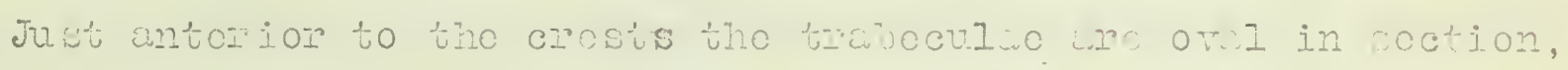

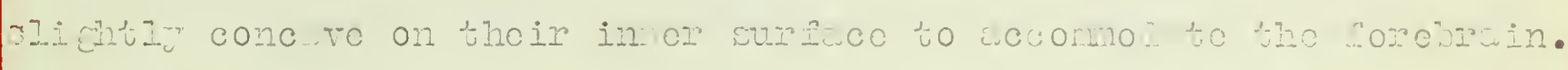

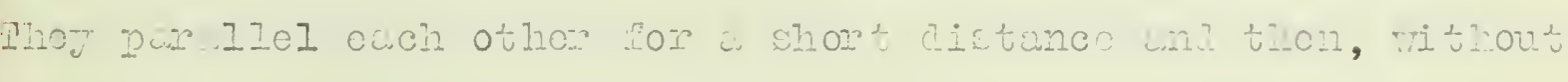

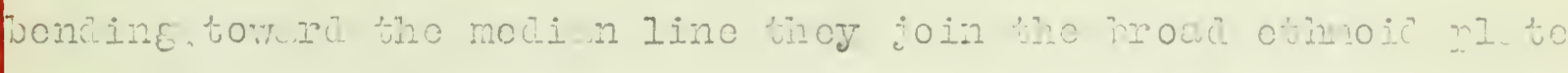

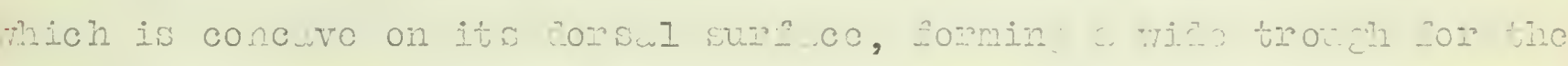

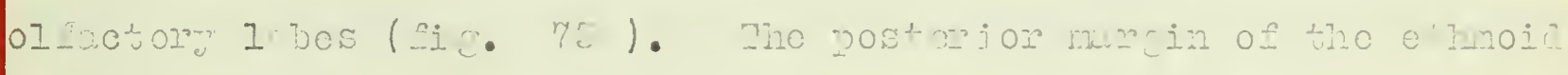

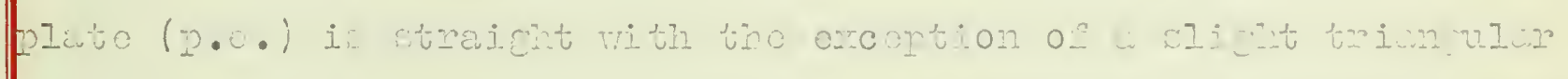

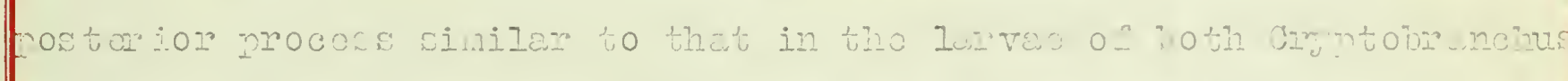

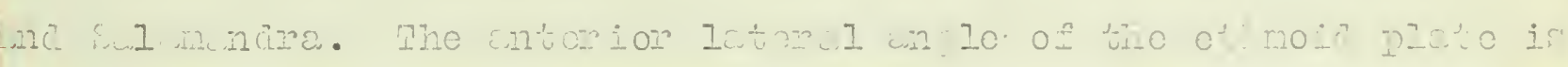

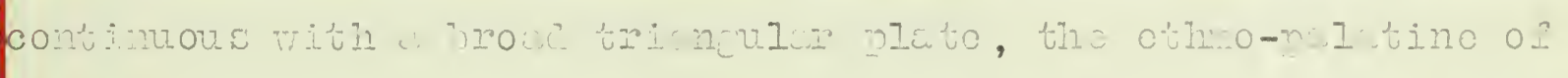

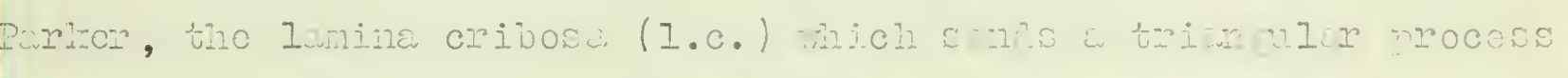

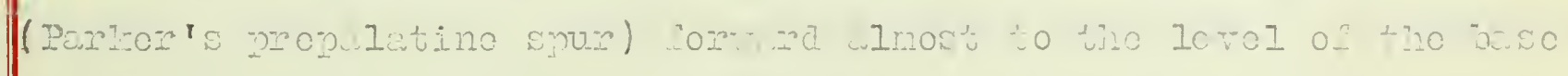

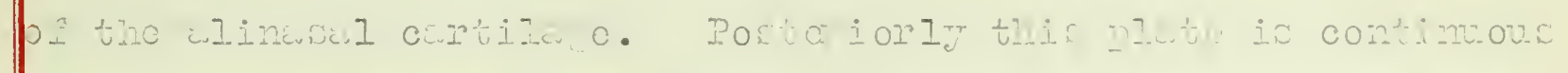

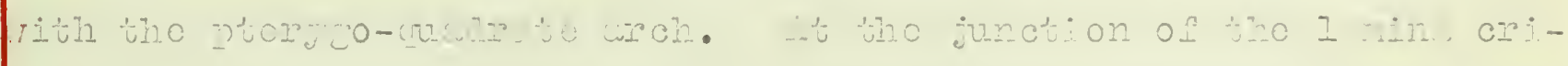

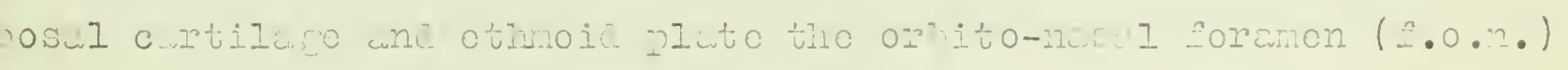

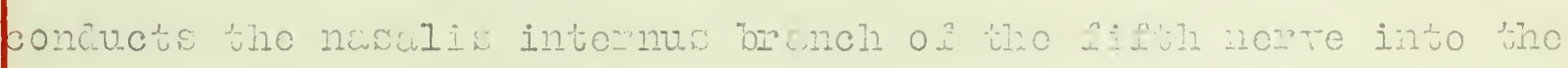

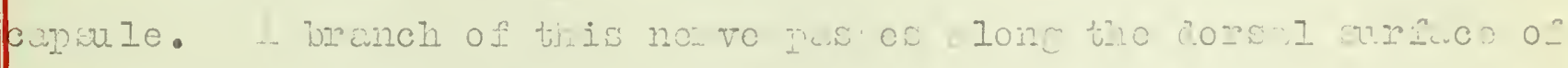

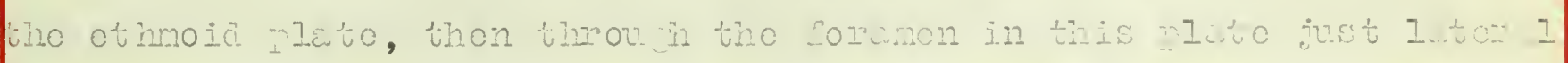

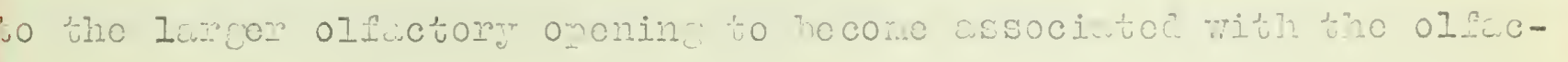

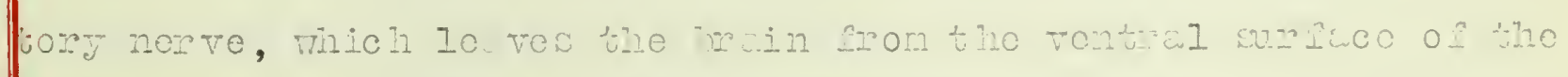
b1:actor 1000 .

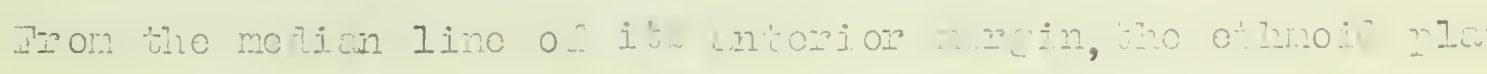

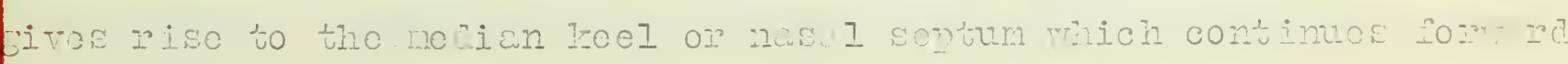





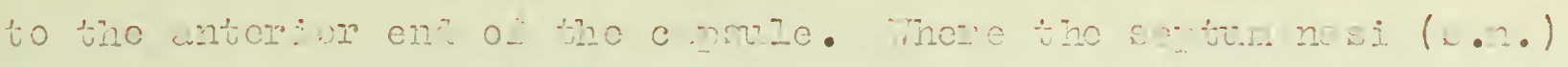

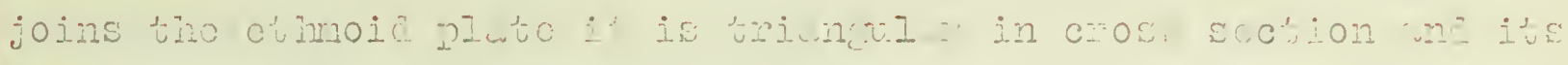

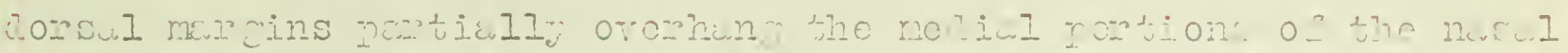

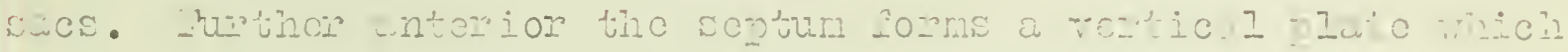

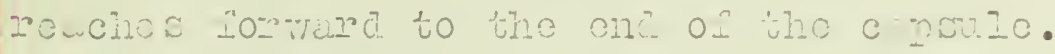

utros of

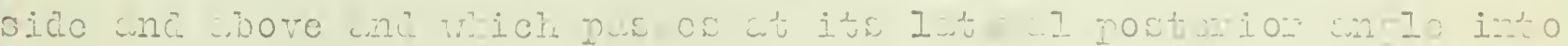

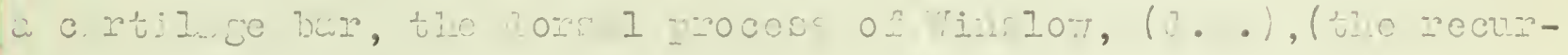

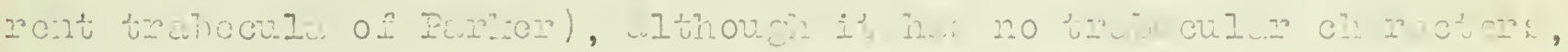

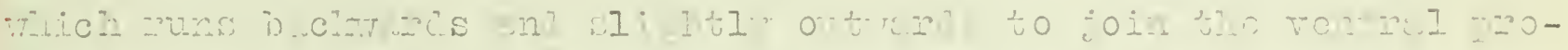

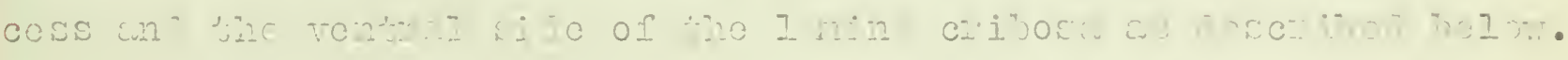

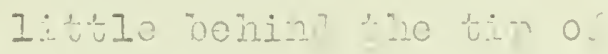

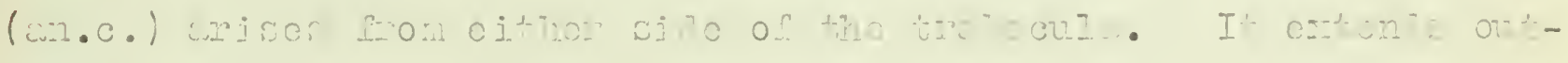

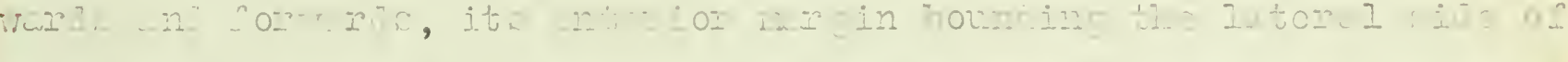

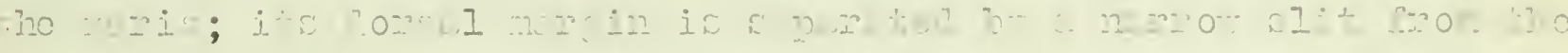

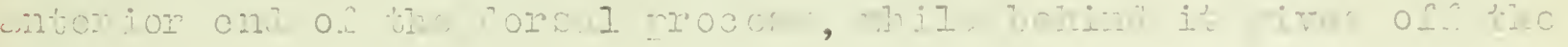
re

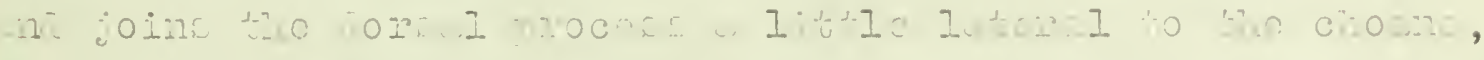

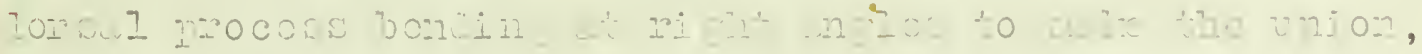

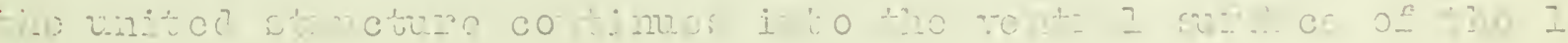
Crition

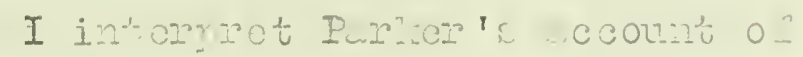

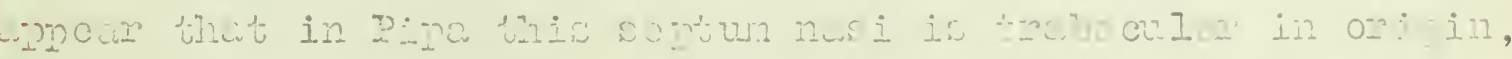

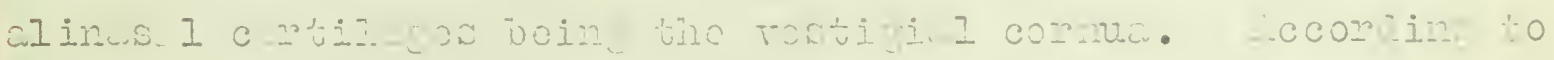

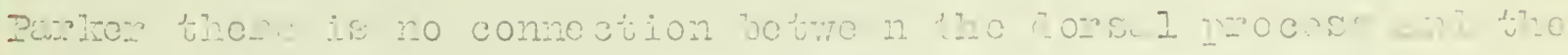

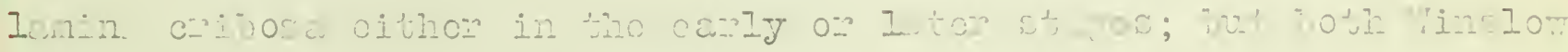

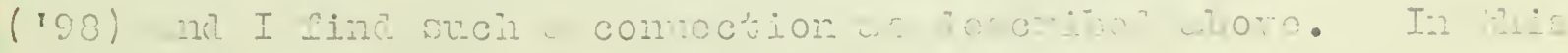

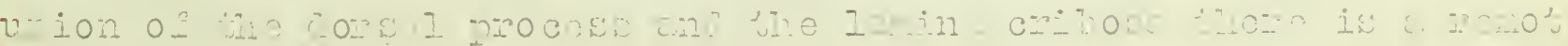





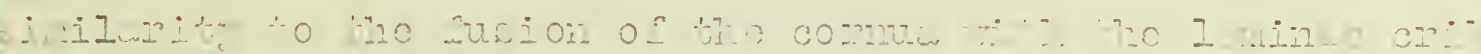

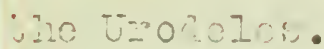





\section{9 \\ Tufo amoricana.}

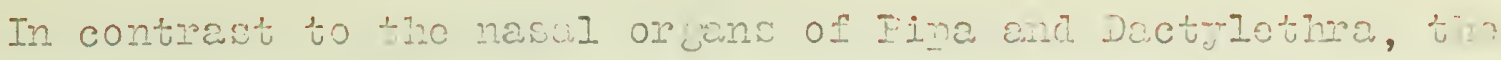

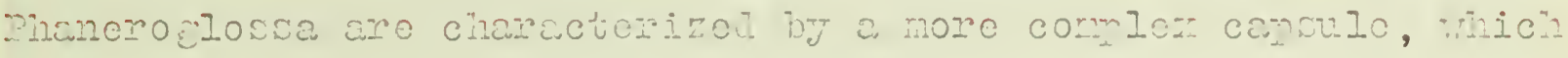

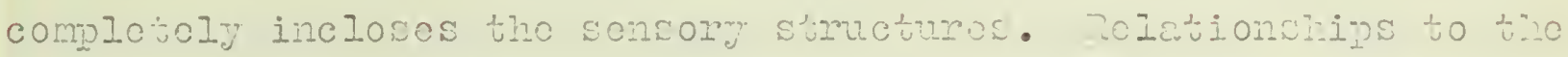

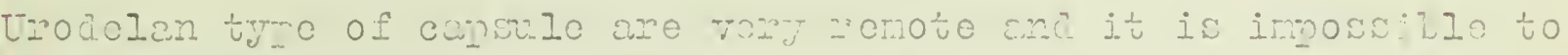

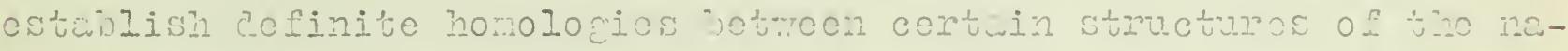

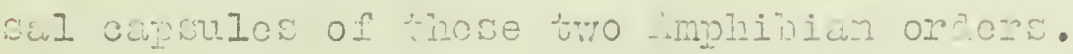

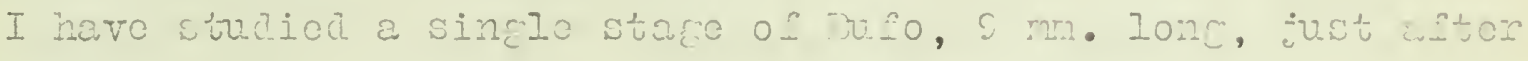

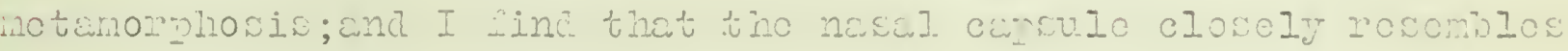

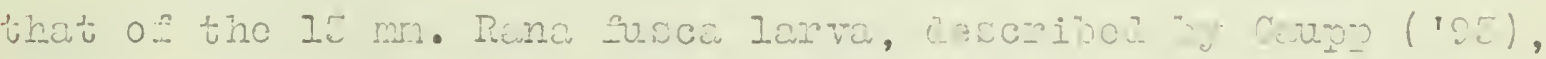

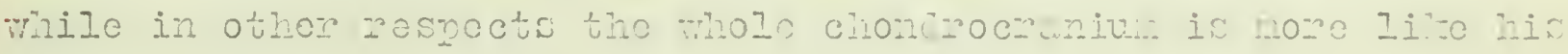
$50 \mathrm{~mm}$ a secoo

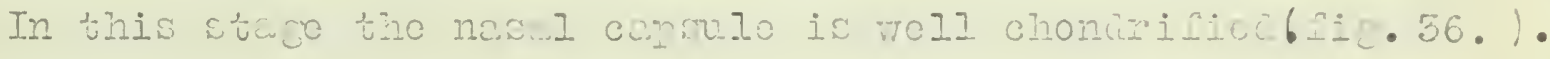

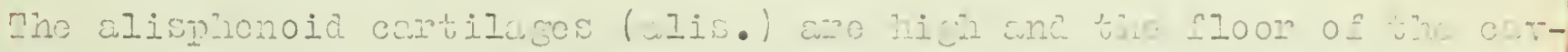

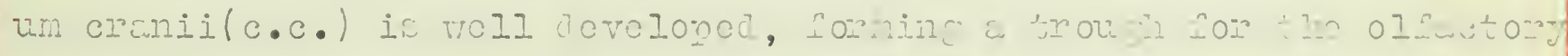

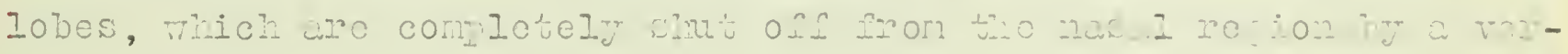

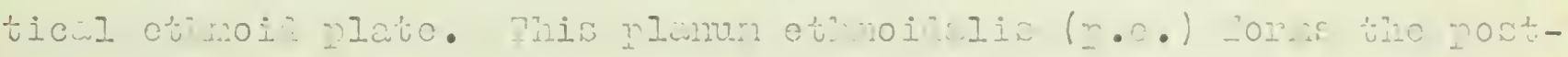

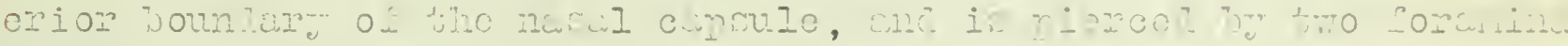

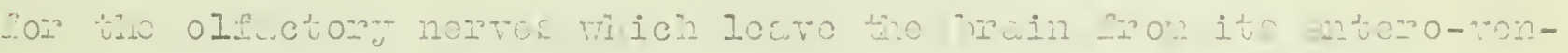

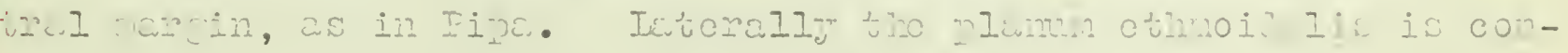

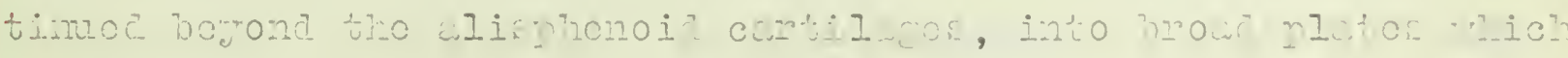

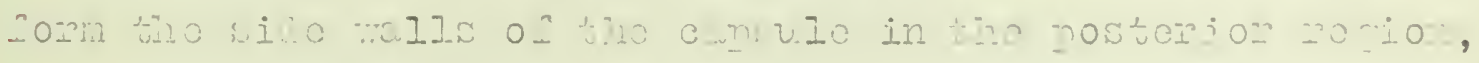

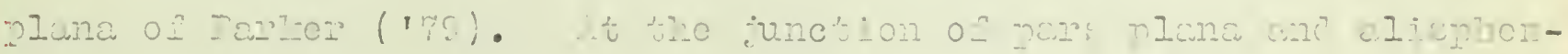

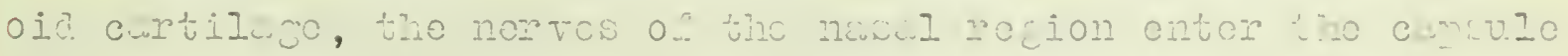

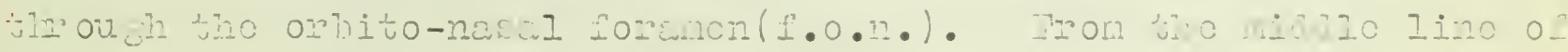

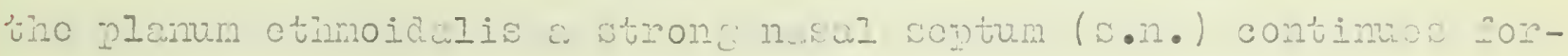

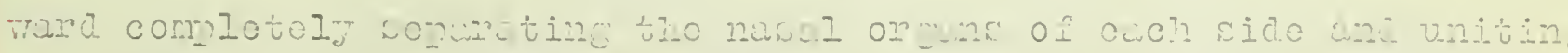

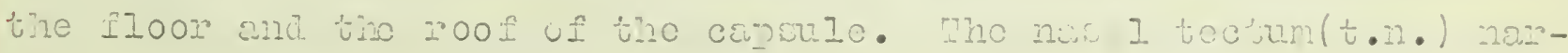





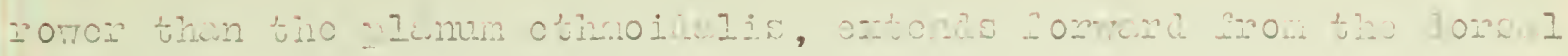

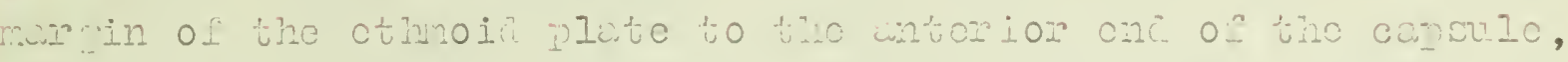

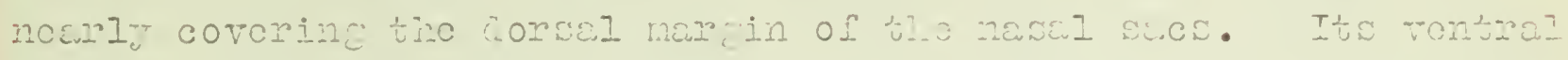

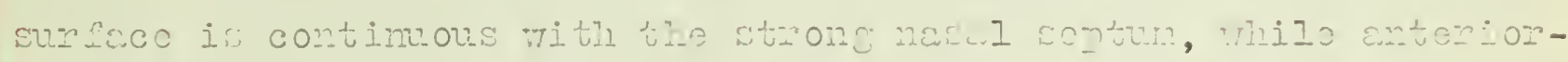

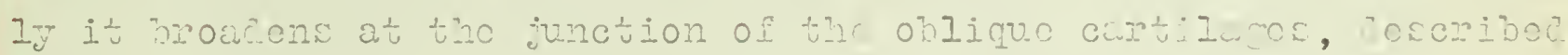

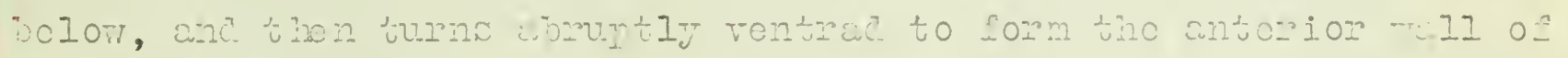

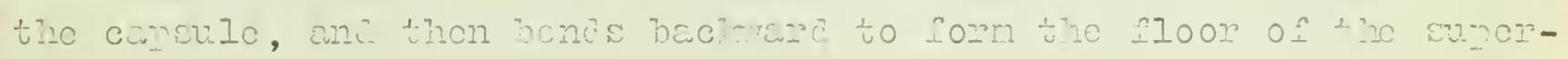

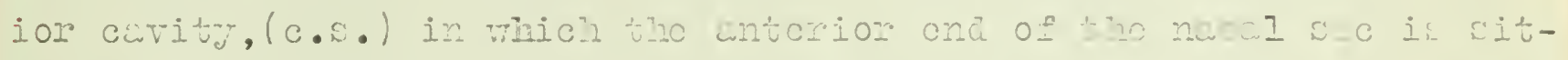

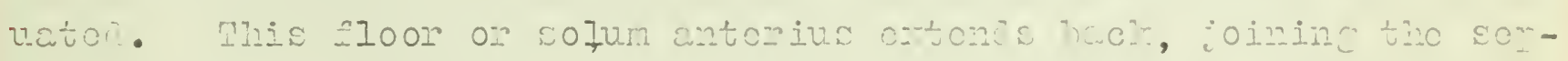

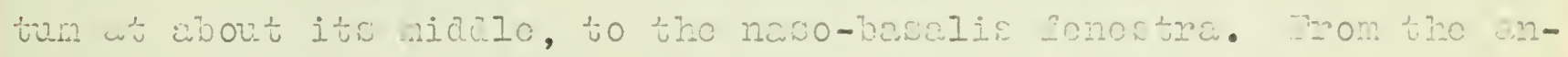

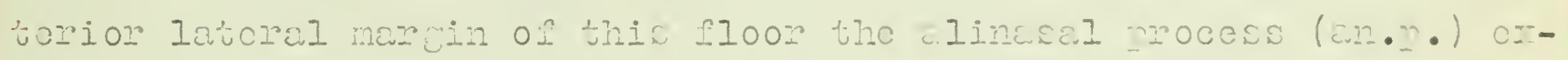

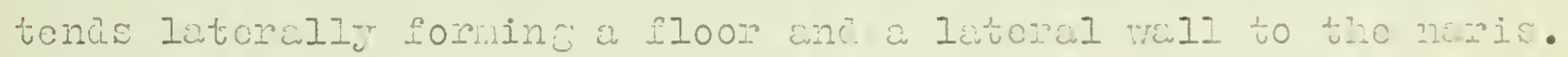

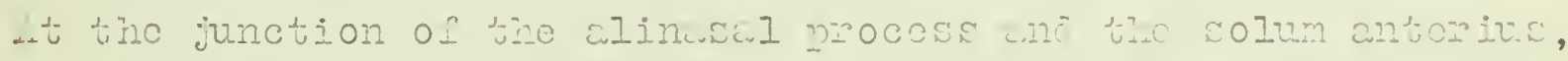

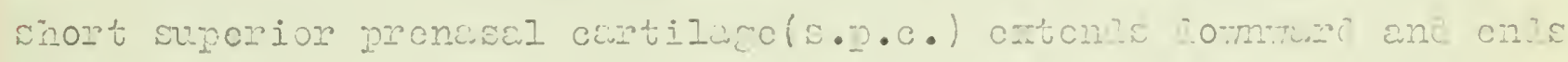

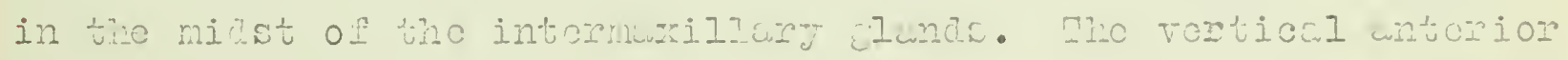

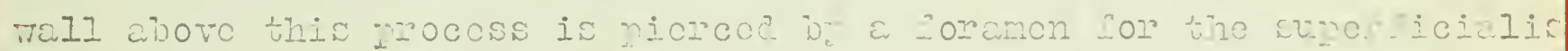
nopvo.

rhe floor of tic cancule noper, the solun nasile(so.nu.), is a

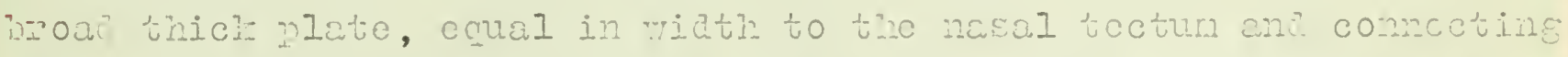

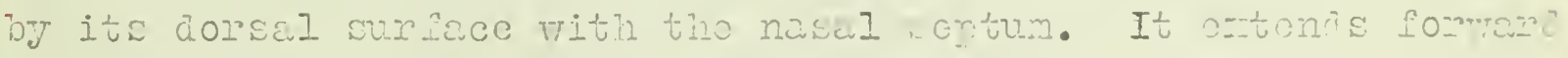

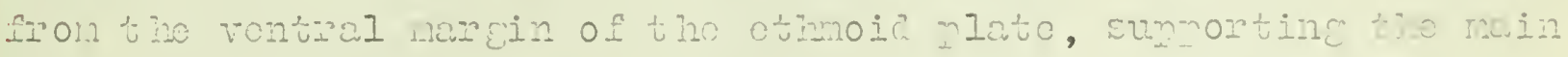

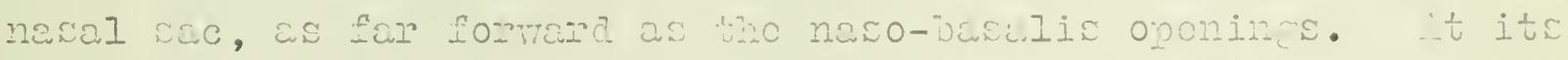

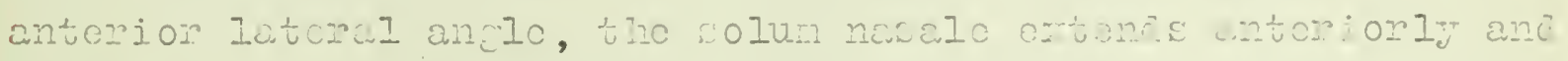

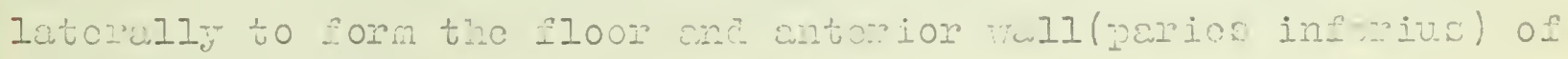
coupp's cerum inforius(c.i.). Whero this wall bonds unre ì cives

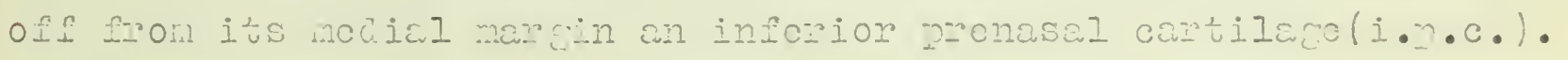
Mom the posterior latoral anlo of the nerios infering a short proo- 

81

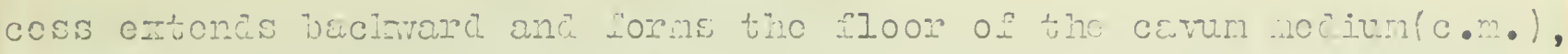

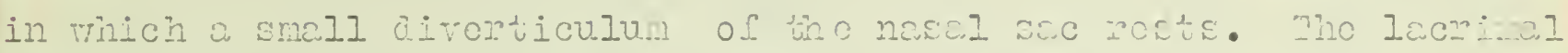

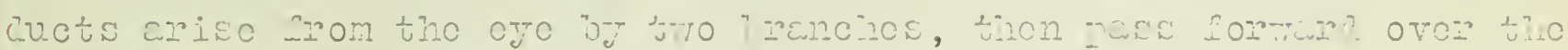

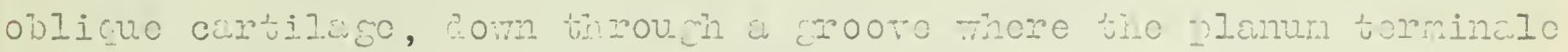
(p.t.) joine tie entonio= wall, ioned to open into tho jomed sile of tho nesel irontioulum.

The lavoral wall of thin ceprerlo is fomod by the oblinua anti-

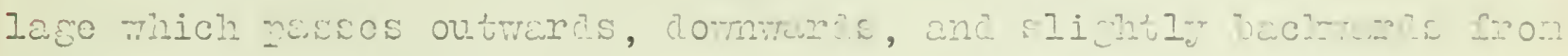

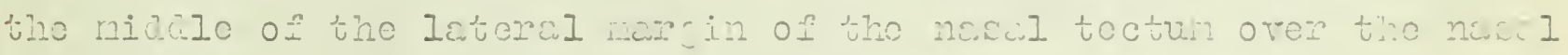

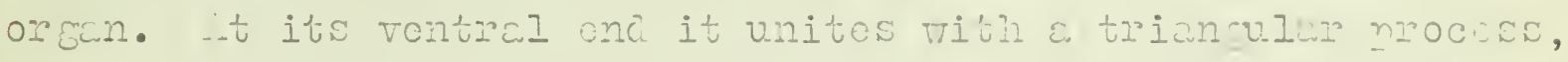

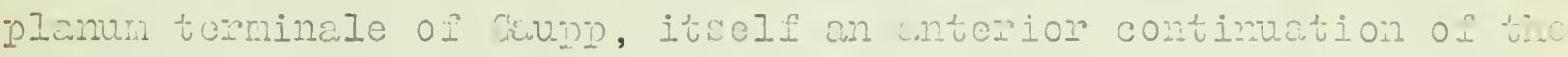
Durs DIand, which unitos in front with tho cutoro-ionsal wall of sino curun inforivo.

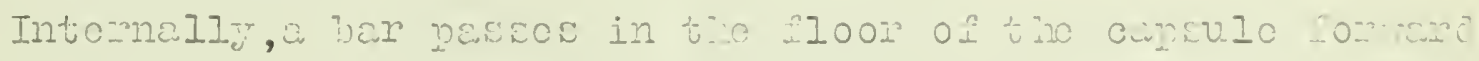
From the solum nasile to join the solun anterius(s,a.), Doune in

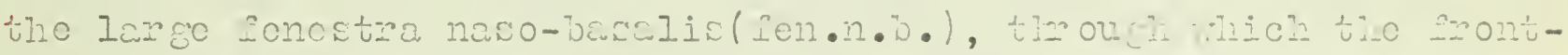

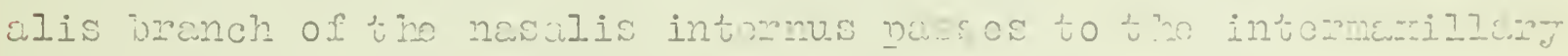

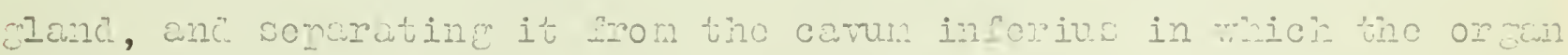

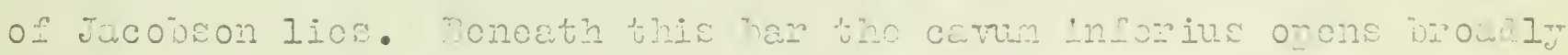

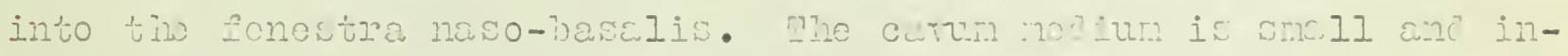

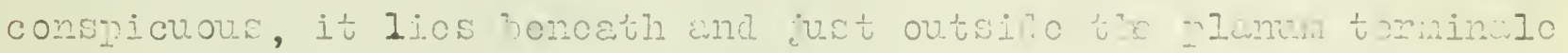

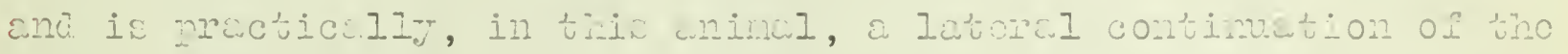

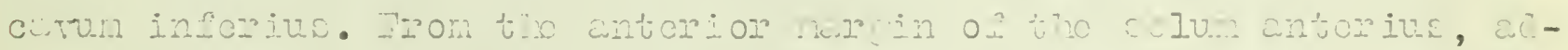

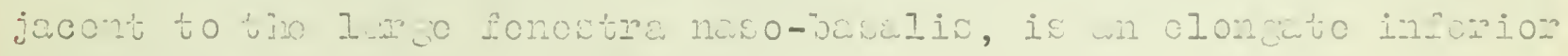
Dionasil mocosis. 



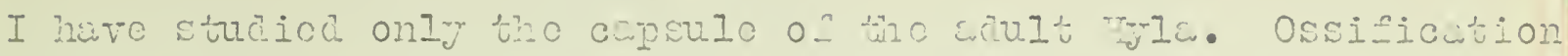

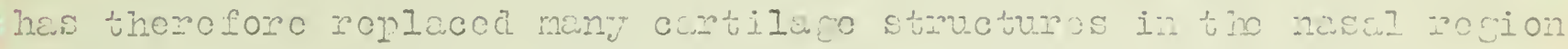

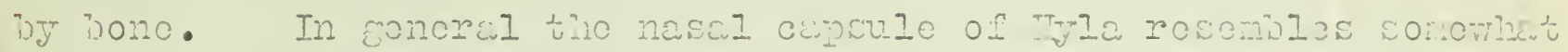

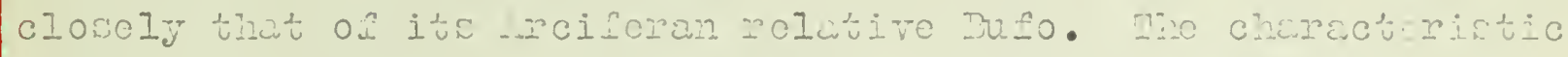

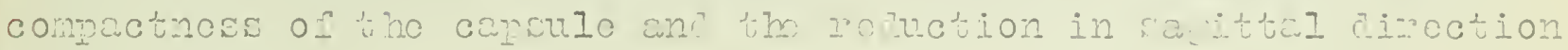

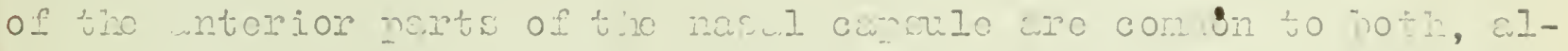

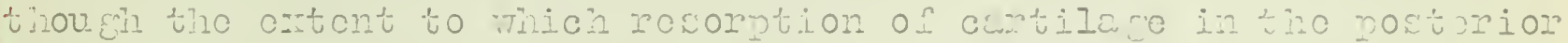

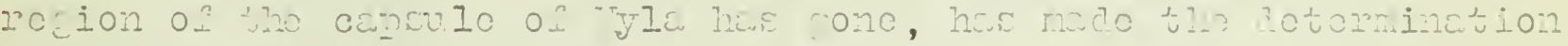
of honologion with Jafo loce co tuin.

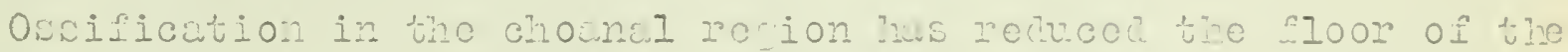

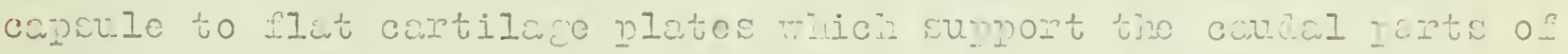

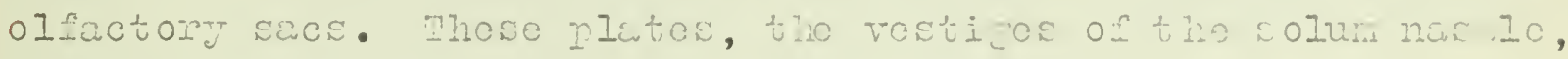

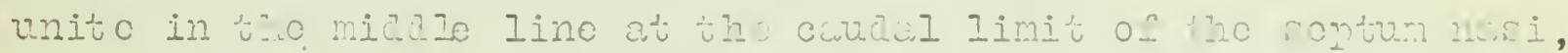

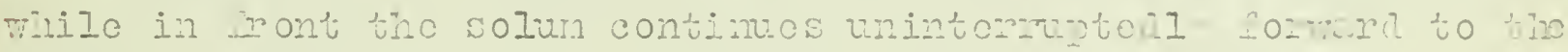
cophulic end of the cunsule. The othnoid plate anz a lingo put of

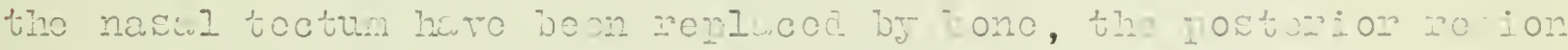

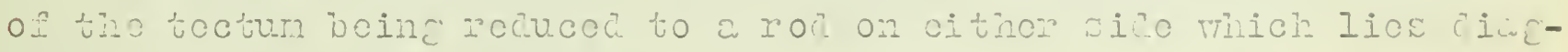

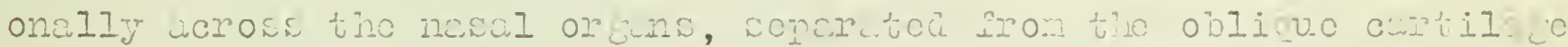
(o.c.) by n olonguto sonostre, both hoin comector by the gan plane. Ihus tho cantil ge structurnos of the postonion rant os tho

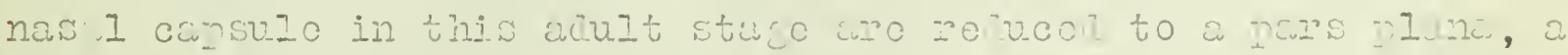

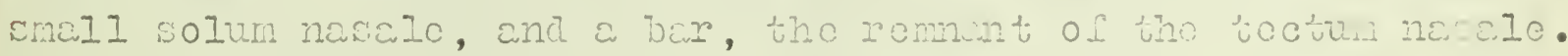
The antorion ene of tro cenculo is moro comloto; the oblicuc cantilage we the bur mich roproronte the toctum inine, unite

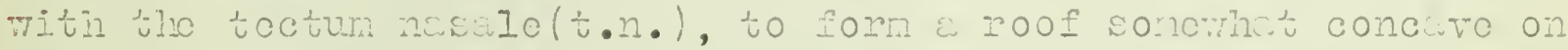

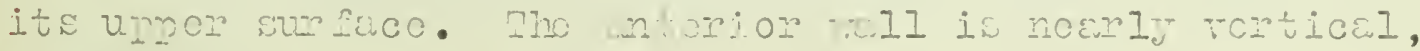

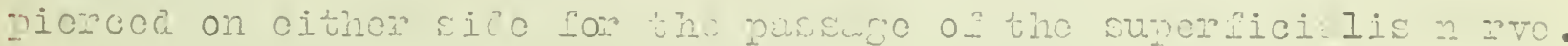





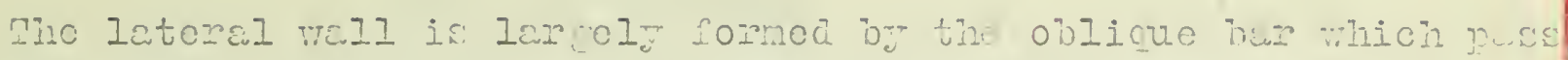
os behind into the pars plana, wh sends commons from its vontur I marein a bar, which I interprot as the planun tominalo(n.t.).

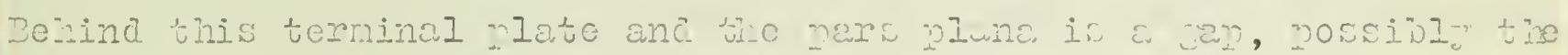
result of resorption, as no neatous or sonom strmetures ness

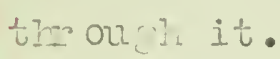

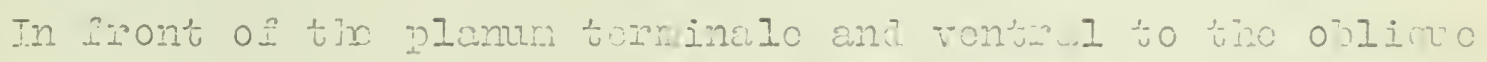

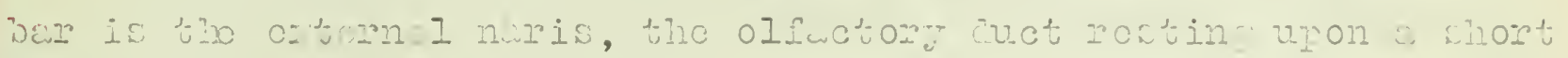

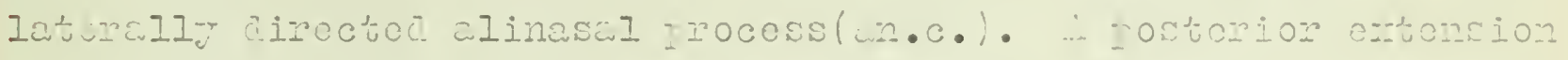

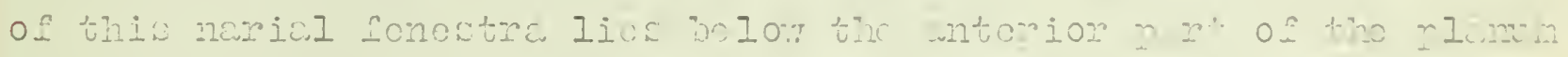
tormin Io win accomodatos tho licuimu tuct,

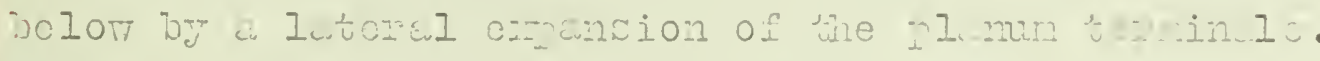
powing this roint ontors the corun inforius.

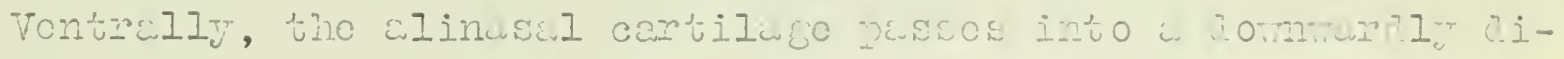

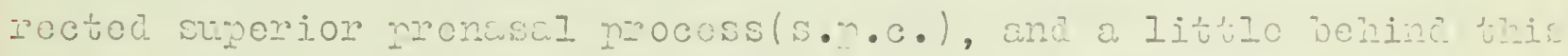

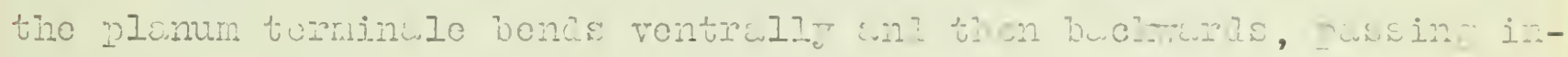

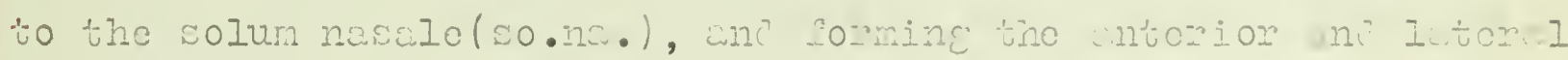

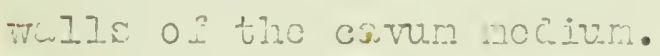

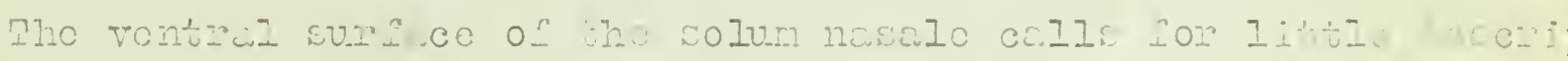

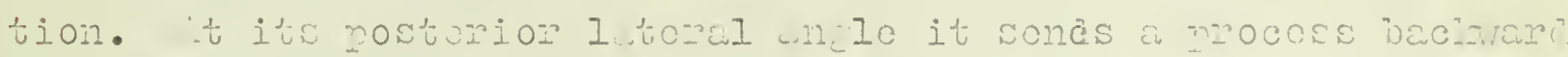

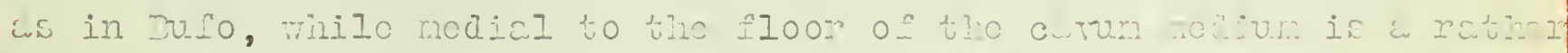

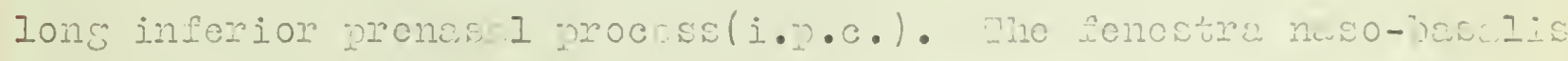

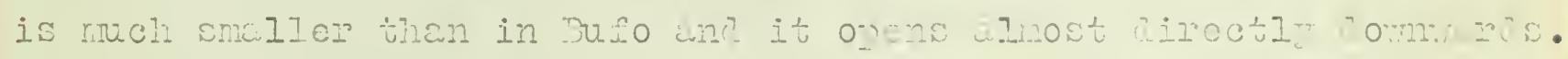

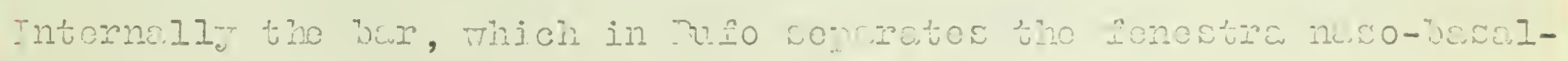
is from the c rum inferive is incomlese in wlu, hoing roprosonte?

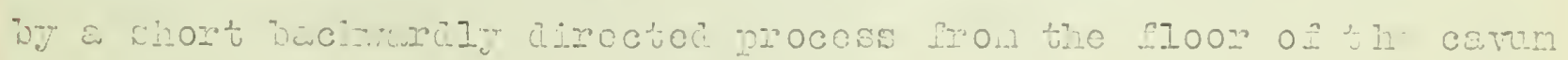
superius. 

Rano, viridescens.

The nasul cupulcs of bno irciforo and the limistornia cue ossontially alilis anc ilthouch I hawe not hat a comploto sories of

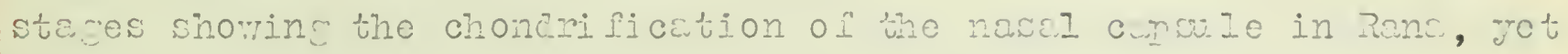

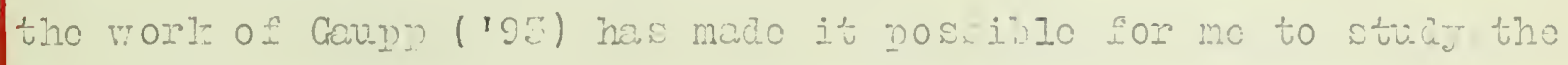
nothoe of erowth of the nes. I c sule in connoction rith tho two stu of that I havo.

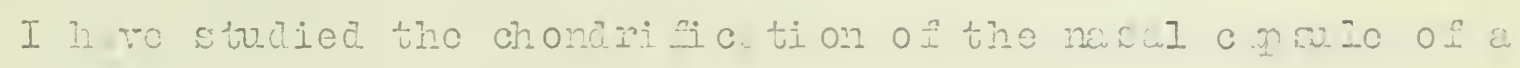
Inrve, $28 \mathrm{rm}$. Ione, total loneth, in fich tho charactoristic inumen

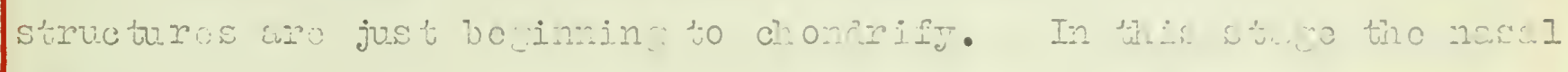

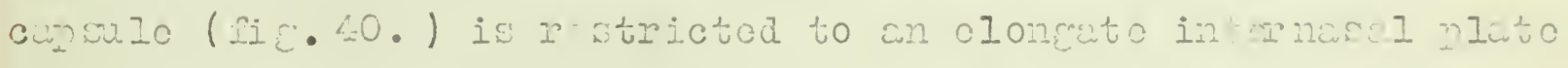

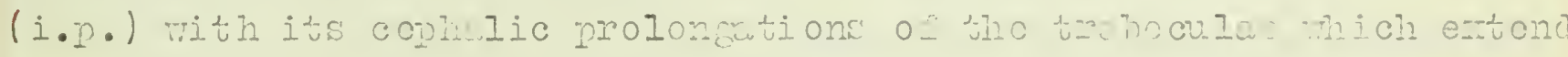

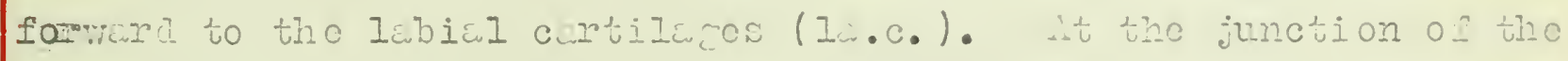
intornas. I platue we tho musculuris procose of tro cuadruto (n.p.e)

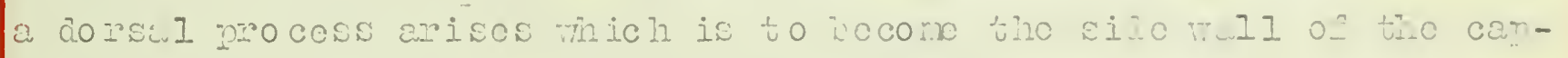

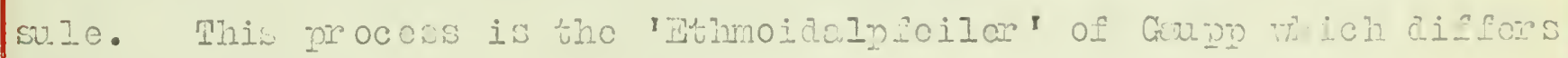

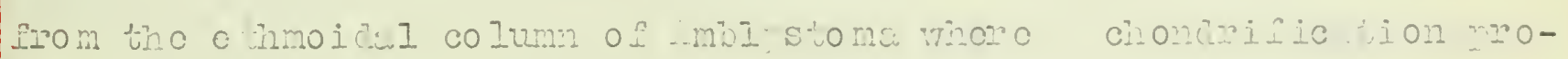

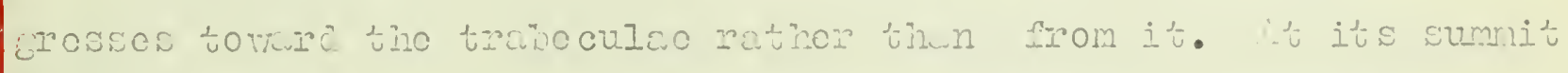

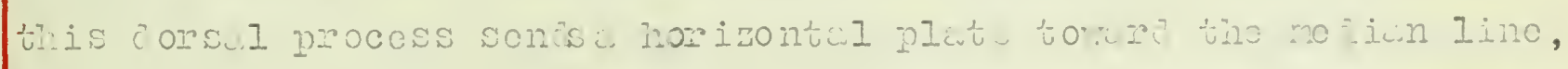
the plates of the tro sires fusin to form tho othroia plato (n.o.).

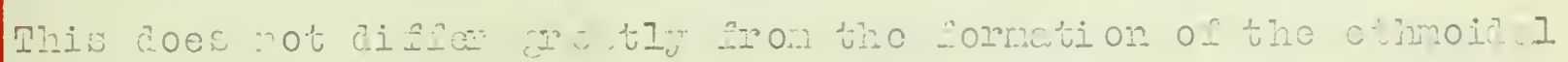

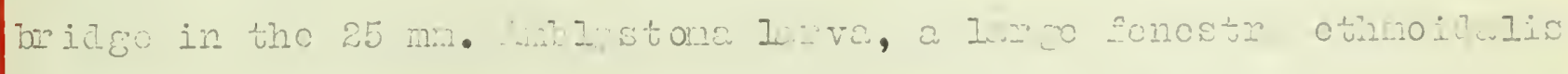

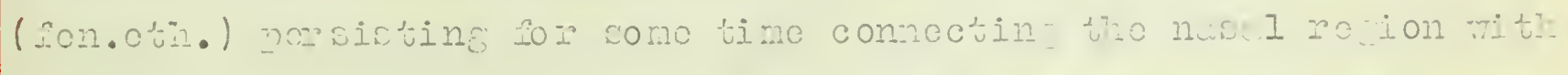
tho crovun cranii. Thic ononin is onl, temporary. Thonirificction

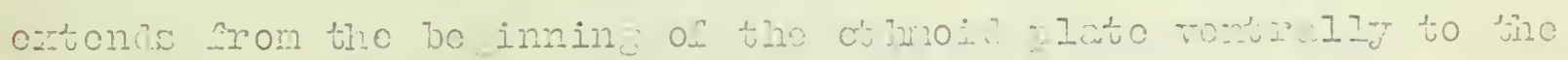

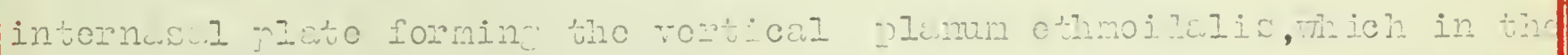

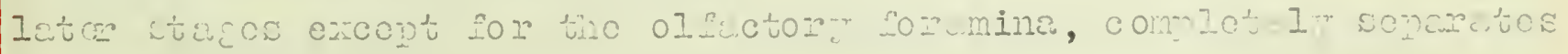

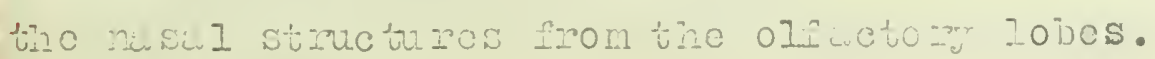





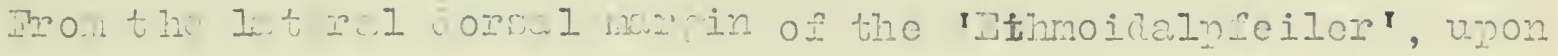

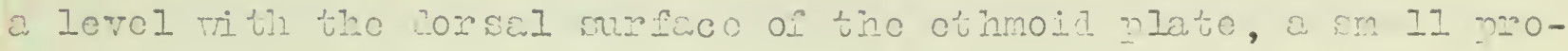

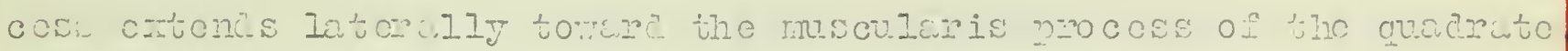

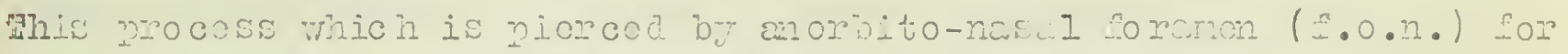

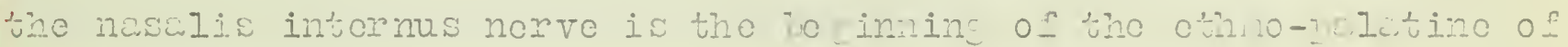

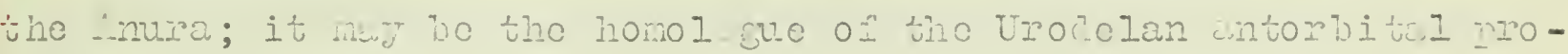

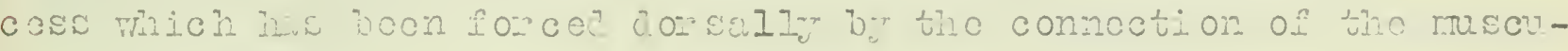

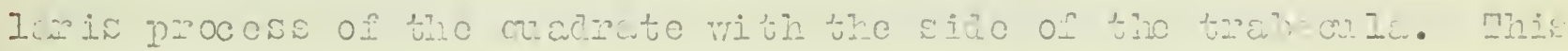

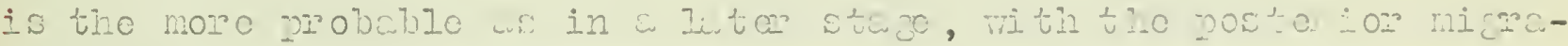

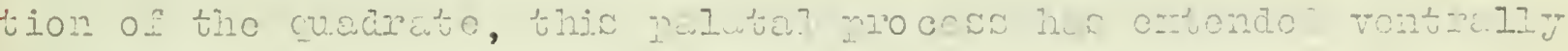
to tho witio of the tringevin.

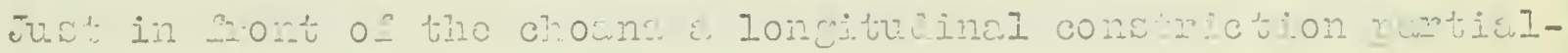

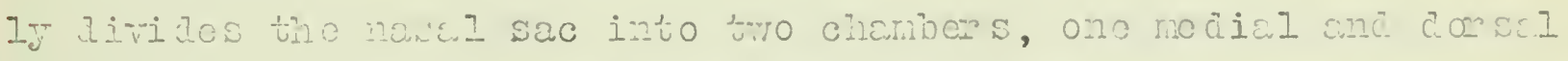

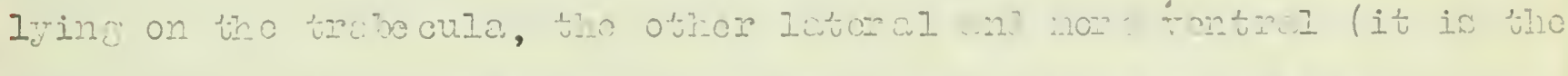

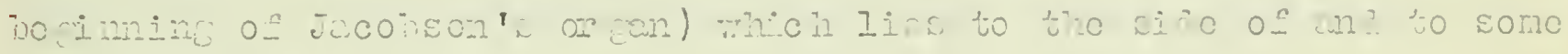
dxtent ventr I to two tre ne lo.

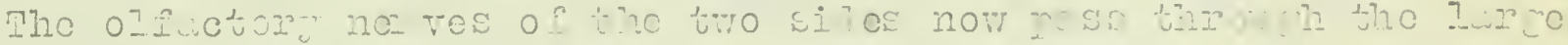

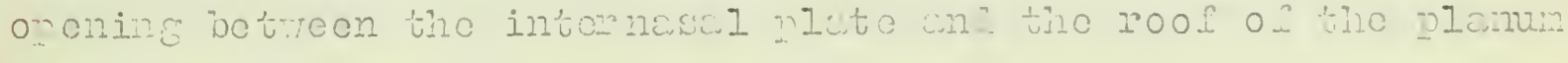

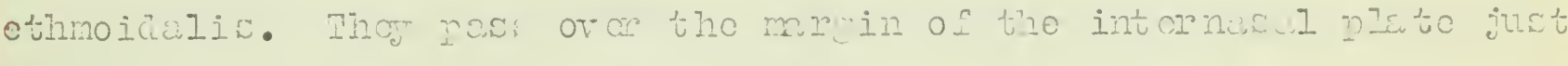

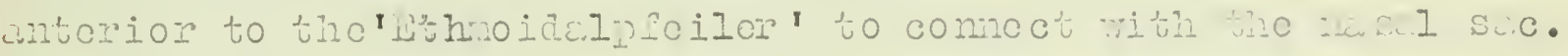

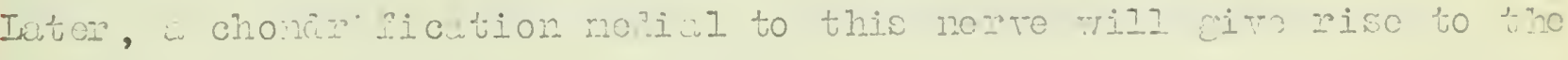
comlete planurn etinoldulis cine njII rosult in the linitution of the

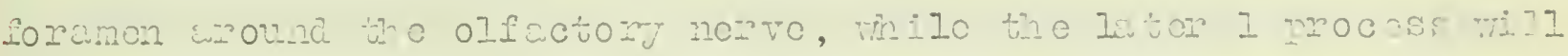

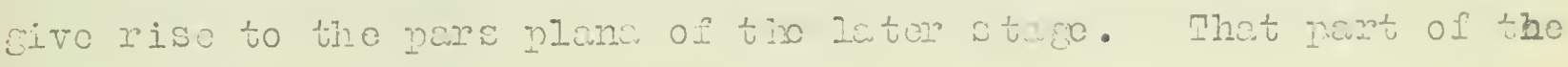

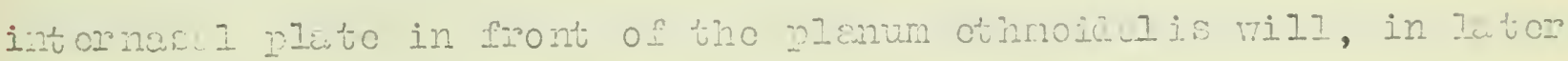
st gos becone tho folum nassic.

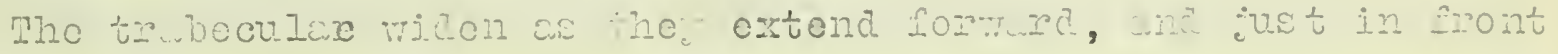

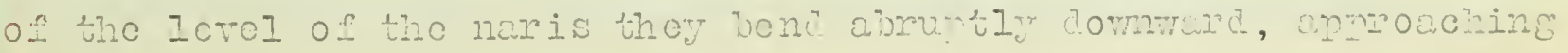





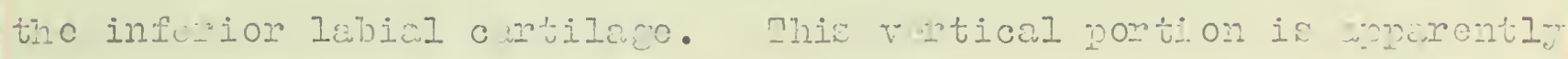

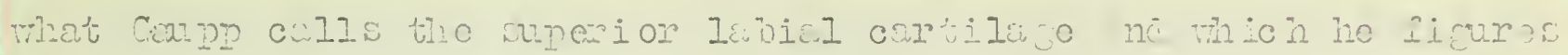
wa a discroto olonont in both ocmilon nn latan staces. In InT

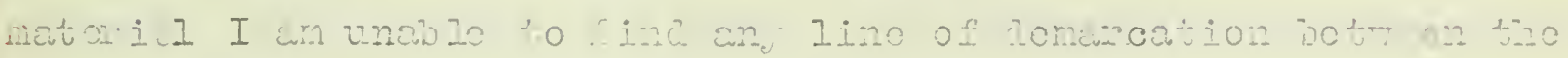

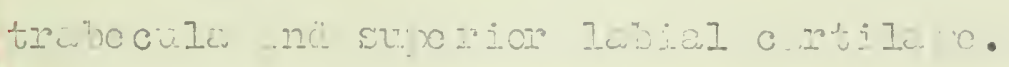

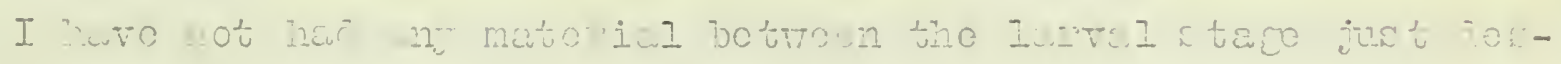

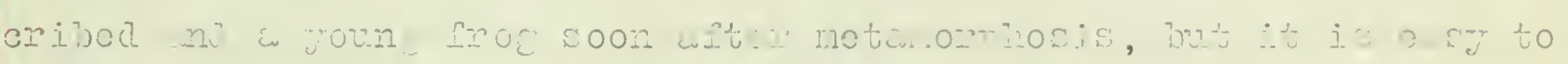

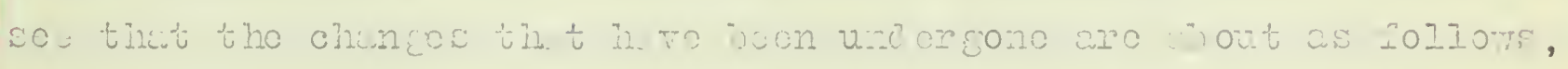

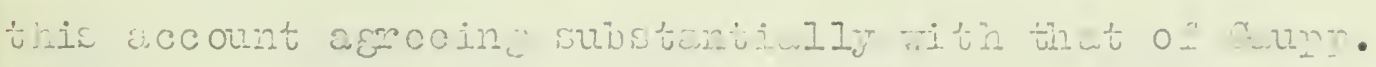

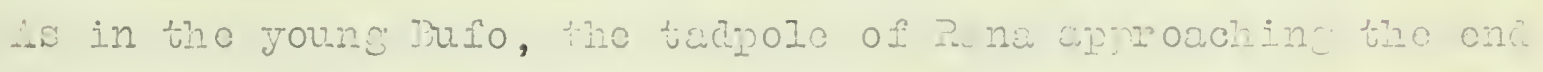

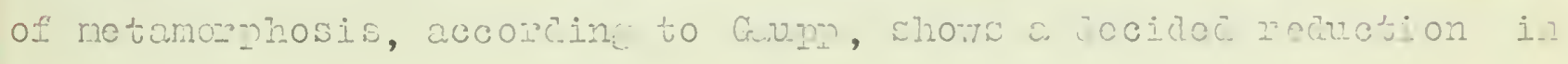

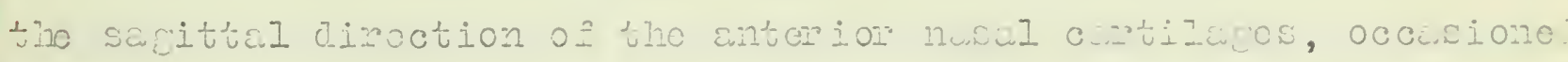

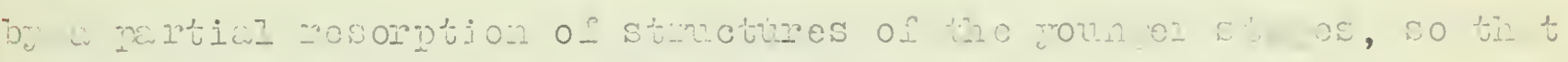

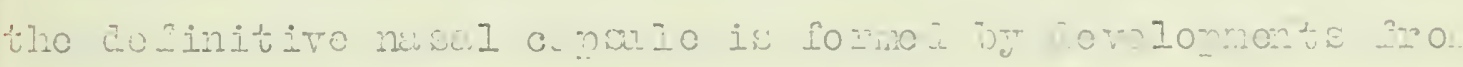

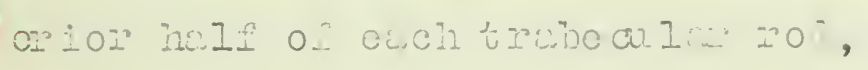

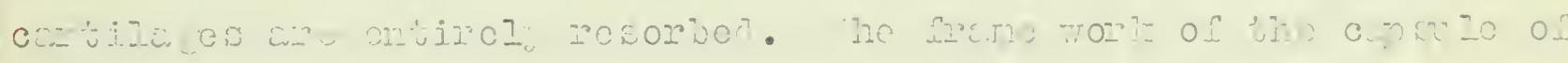

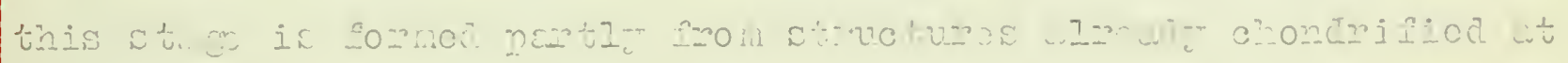

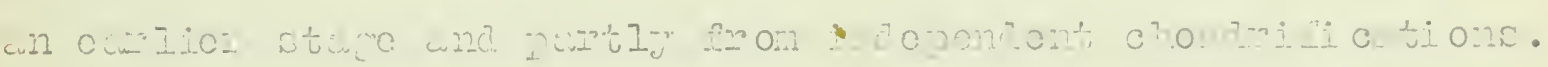

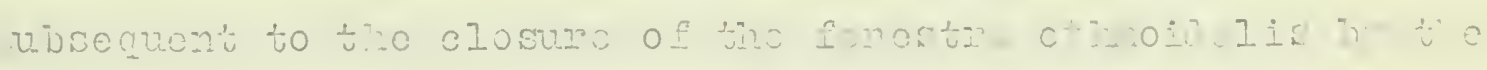

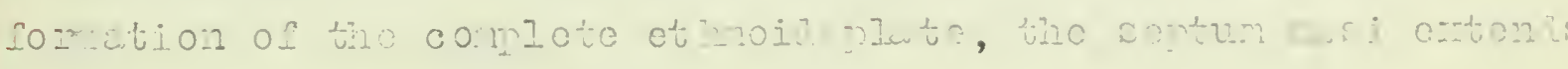

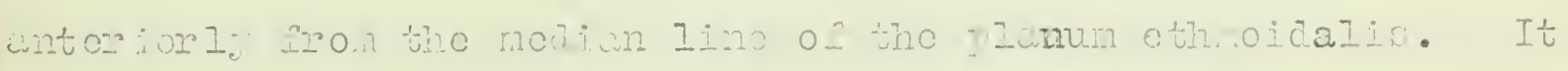

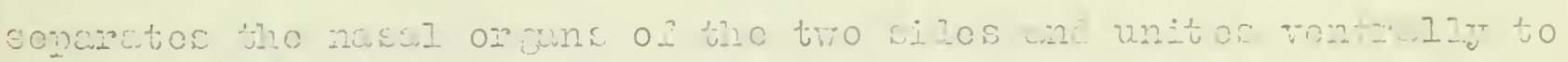

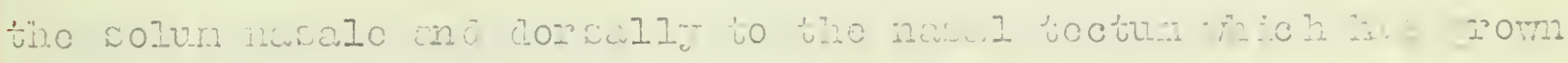

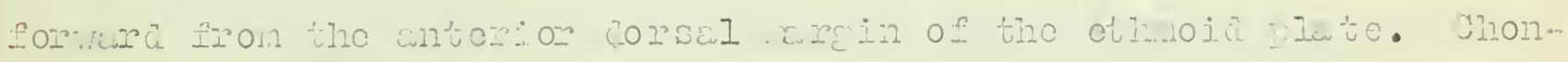

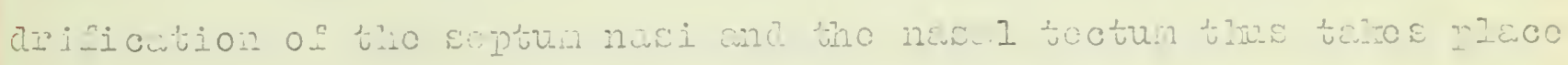

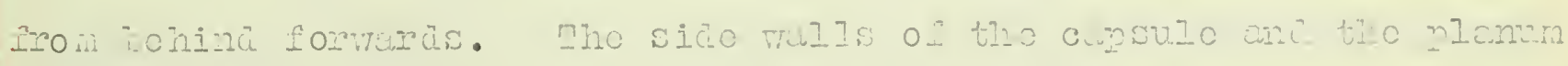

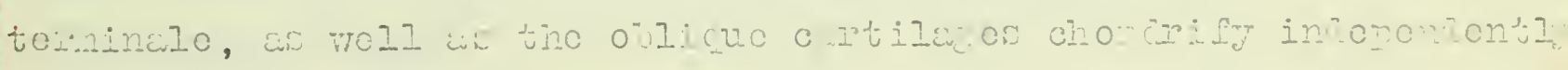
End unto to tho nawal tocturn whe tho solun huswlo, bounding tho 

Ieteral vars in tie capsule.

In the anterior pant of tro consule the patest noinication talrea place. The loss of tro labial cartiluges and the antarion parts of the triboculce, results in a fore and eft condonscution of

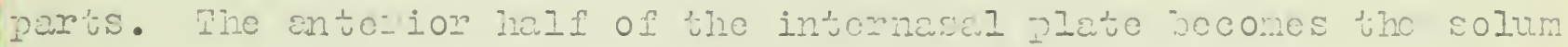
nasale, while in front tho trabeculac ivo riso to the culinascil cont-

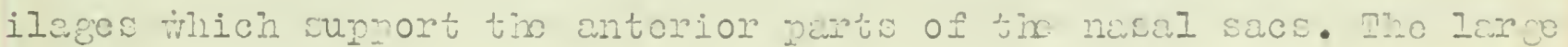
naso-bcosulis fonewtra betron tho solum nascle and the clinascil cant-

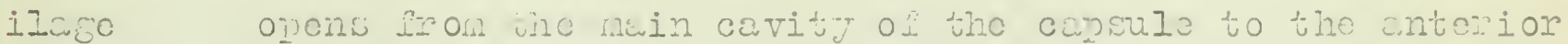

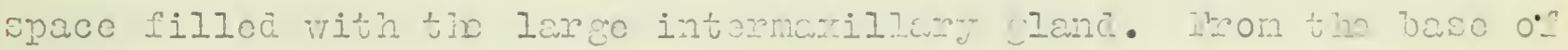

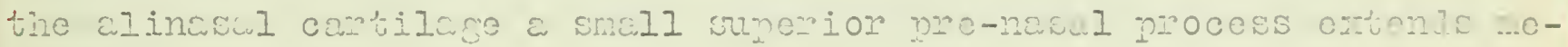

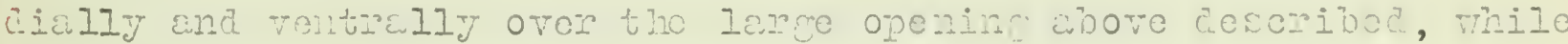

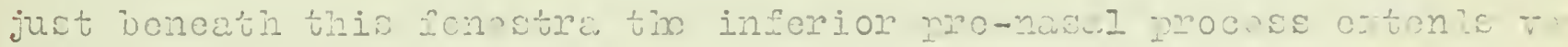

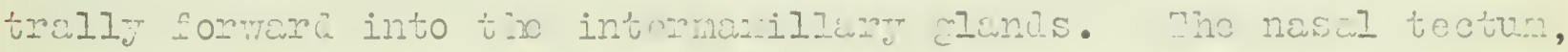

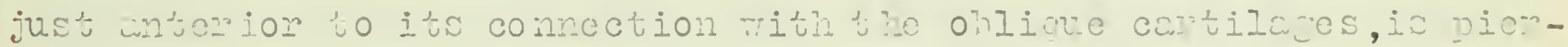

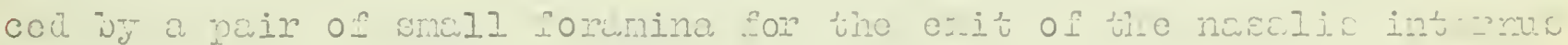
neIVos.

In this wtuce the outiculution on tho lower jur has moved bacle so thit the deoply currod muscularis process of the vadrate is noro

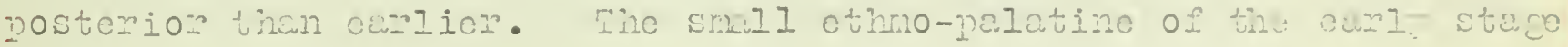

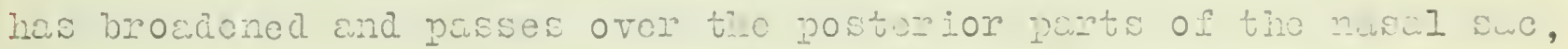
end thon aivilios into tro processes. Of these, an wntorior mexillaw procoss extende form are to tha lotol of the postarion end of tho obIicue certilaco, while the postorior is the eirrect continuation of the pteryoich areh. This relation is similar to thet in Juso, al-

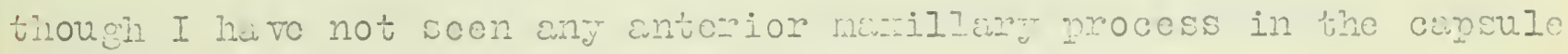
of the lattor folm. 



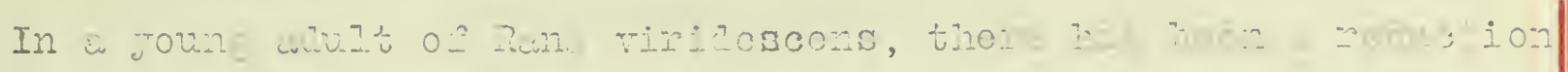

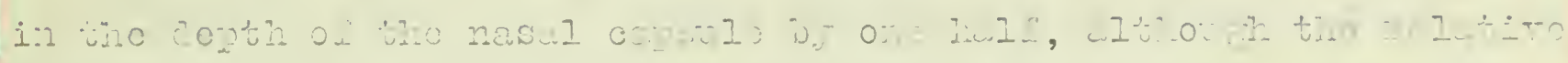

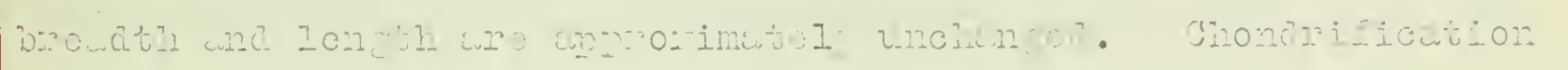

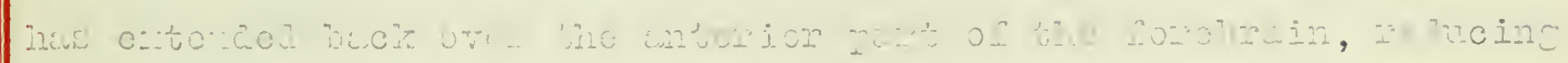

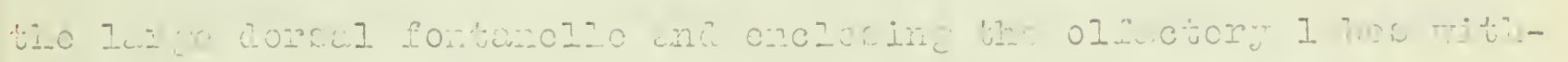

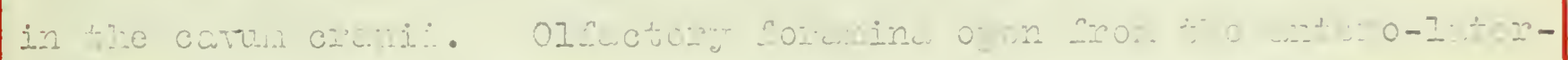

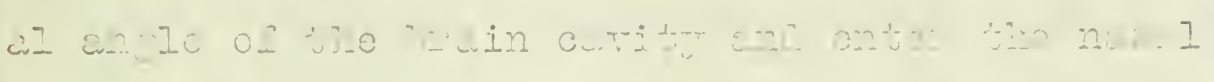

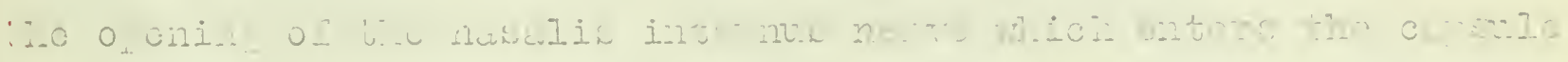

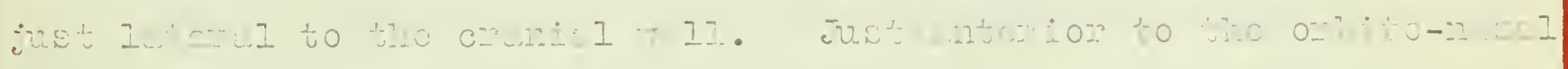

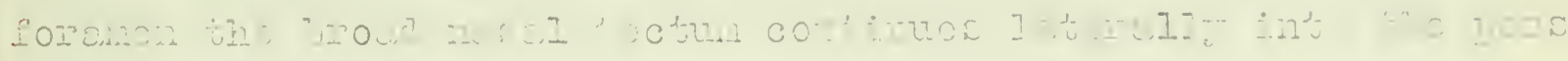

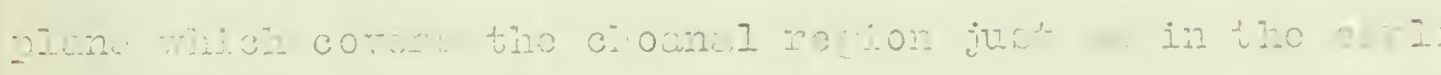

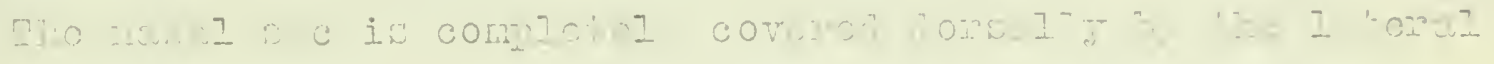
ide

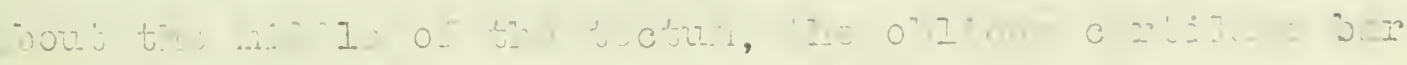

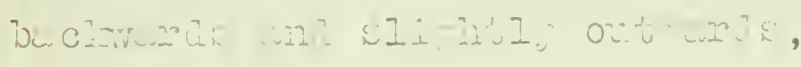

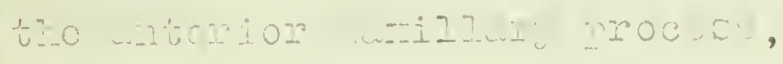

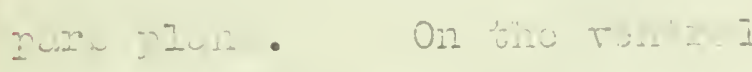

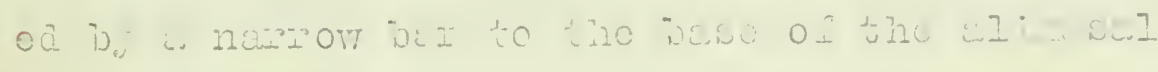

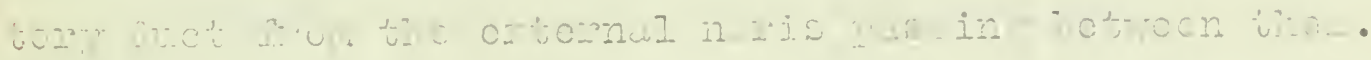

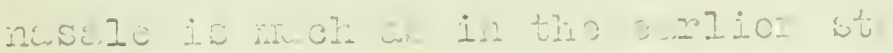

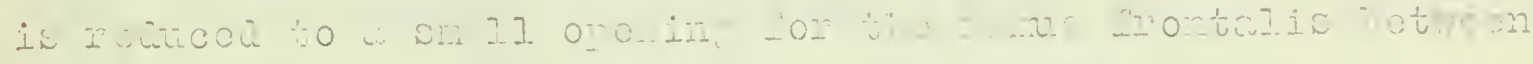

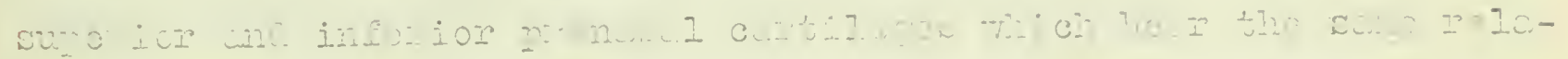

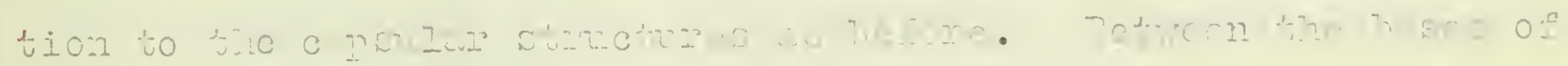

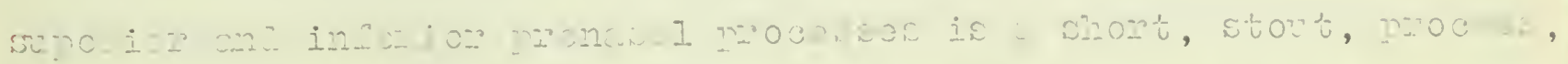

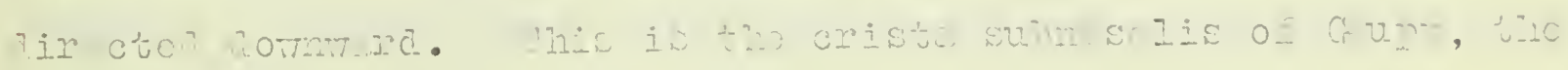

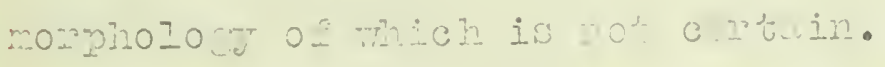





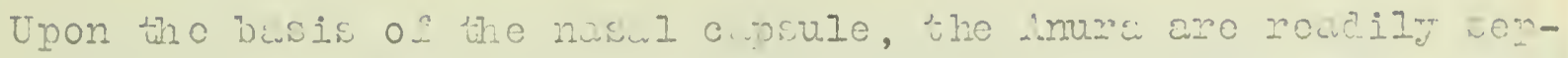

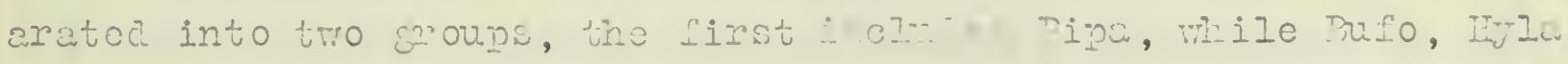
and Rana belong to tie wocond. This distinction is in leo ine vith

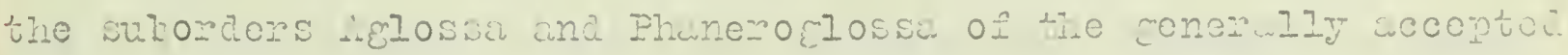
classificution. The cunsule of Pipa with its lare vicutica is very difforent from the compict one of 3ufo, and at first sicht bewre is

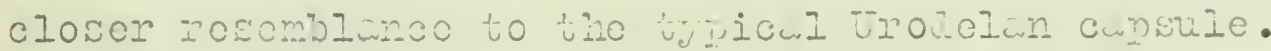

There wre some murtred roseriblinces betweon the cupules of thene Anuran groups. In both, the ptoryfo-vintrute wroh is complete und

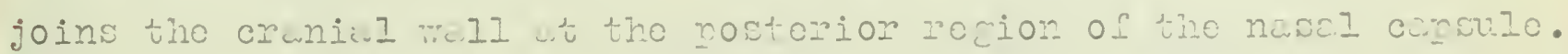
In Pipa, the purs plini(in nwrt, a portion of the rtoryoid) fusos

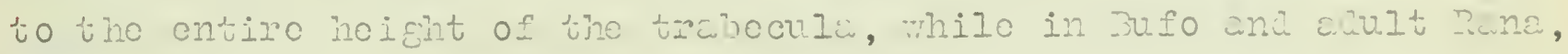

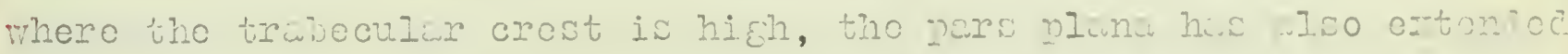

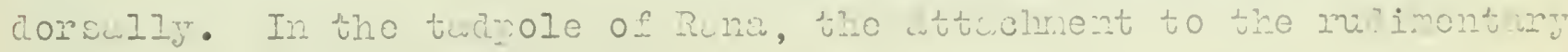
Jurs plina is to tho dorsul purt of tho criata, this nosition beine probsibly tho result of the wtucchmont of the macriciris procoss of the cuarrate to the trwbecula. In wl dinvathe orbito-nus-I forwmen pierces tho cupsule whore the ntcryeid unitos to the tribecula. intorior to tho junction of tho pterroid to the craniw will, a procoss extends antoriorly, partiully corering the nasil orcuns. This is the othrno-parctine of Earker on the rlanum terninale of Gapp. Wuthor, this procoss ives riso to tro bars which bear similar rolations to the nusil orewn trrourhout the onder. Ninslow calls those bors, the rentreil and dorscl processos, wnd thoy may be rowily comparec to the oblicue cartilese win the solum nterius of bot: Dufol and Rena, althouch thoy are moh shorter in the latter forms. In both Eipa and Dufo, the oblicue cartiluge(the dorscl procos in Iipa) 

passes corsally and intoriorly orol the min nosw sec to connect with the nasul toctum or litoral expansion of the sopturn nisi; wilo the ventral procesi passes jonowin the orgen of Jacobson to connoct with the alinwal mocess which wuports the cutorior end of the nasul sce. The ventral procoss is the rocurrent trabeculd of Parler which develops Anon the internisal plute meh as the cornu trubeculeo of tho Urodoles, so that the solum unterius of 3ufo may be the homolo Eue of the Urodelon cormu.

In my last stage of Rine, the plunum torninuio of Gunp's touneor stege, becomes the antorior maxilliry process. It hwa now soparatod from tho oblivo curtilago which torminates biuntly now the latoral murgin of the tecturn. Further, tho rontral process is not connoctod with the moro nowtorior arructures, but porsiats wa a small cartilaco jugt vontral to the wuprior pronesal procoss, and is not tormed the crista subnidulis.

Superior and inferior pronwsil cortilocos as such are not mresont in Pipa, and yot the froc tip of tho linwal errtilie which is separeted from the chterion ond of the doncul procose by a crocecnt-

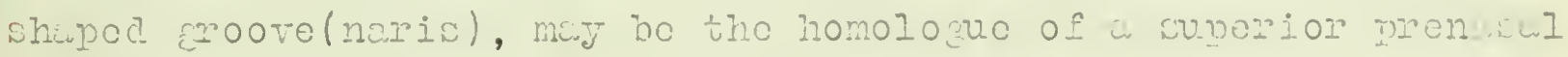
procoss which is airocted vontrally in Bufo. Jurthor, it noos not violato probobility to ws sure thet the pre-pelatine spur (Perlor) in Pipe raw bo the homologuc of the inferior jrenwis certil ge of the Phanorogiossin.

The nosil. tectum and solum nasulo cre eridenty an additional Eromth in the Phaneroglosse. In Pipa there is a slicht oriconce of a tectum in the nostonior purta nd ince the toctum nase le of Rana devolops an eriorly from tho othmoil nlate, it is possible thw tho

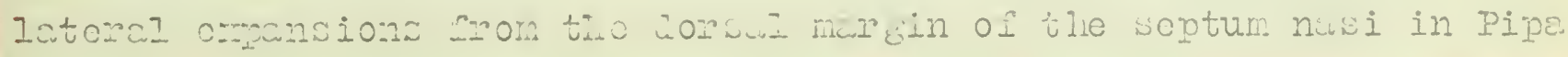



mity be the becinnine of a copsular roof.

The planum cthmoidelis in Pipe is homizontal, nd wa in trosclos vory slikinty concure dorsully for tho olfictory lobes. In the Pluneroglosse, the cthroid plato of authore, is a roptickl purtition complotoly sepuritine the nwal region from tho curum crinit. It it picreac by the olfuctory nerves which lecve the brein fron its sntorior norbin in tufo anä Rene, but more vontrully in Pixe. From its lateral marein, the othroid plate unitos rith the pars plana, which in all inver has fused to the ptoryocumeto woh.

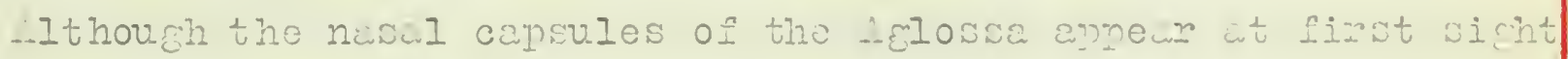
very different from trose of the Phworoklossa, yet mun homolowies exist. The ptoryco uarate wreh, planum temrinule, oblirve cortiluco

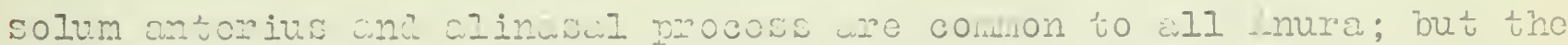
complete nascl tecturn and solum nisale are cuditionil chancteas of the Phaneroglosis. 

Jiscusion.

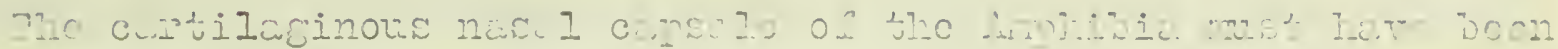

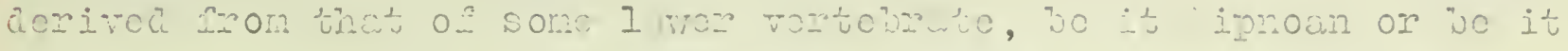

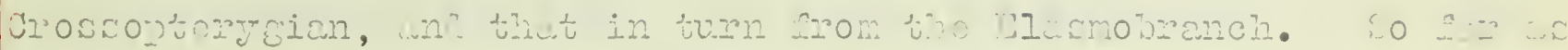

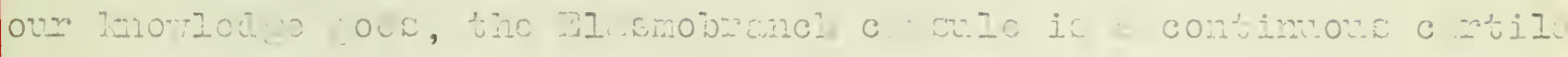

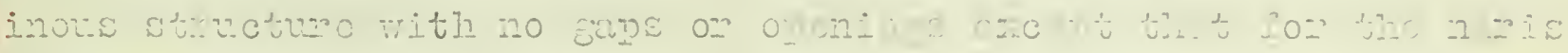

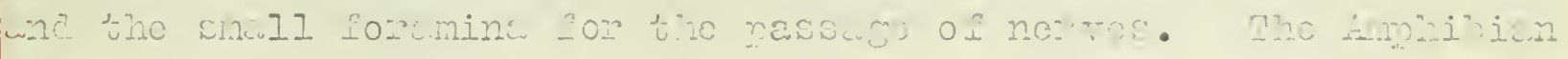

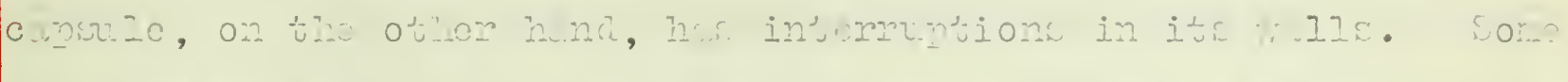

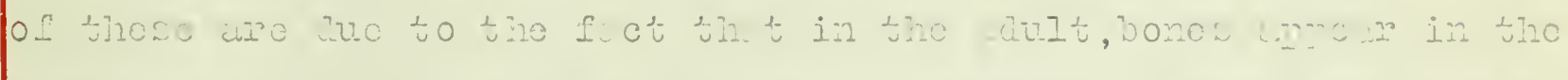

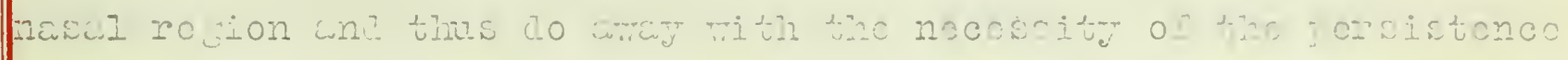

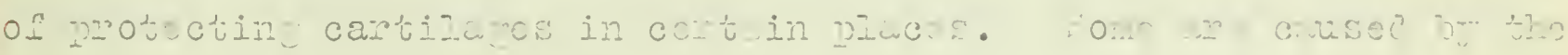

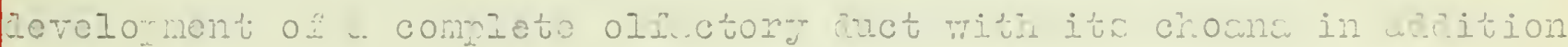
to tho misis.

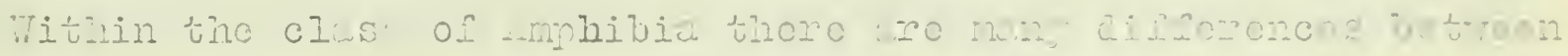

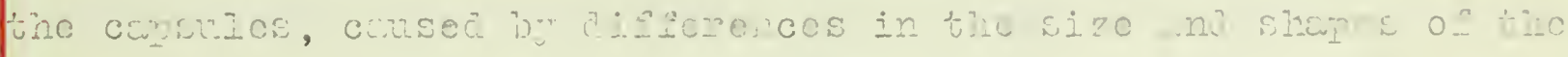

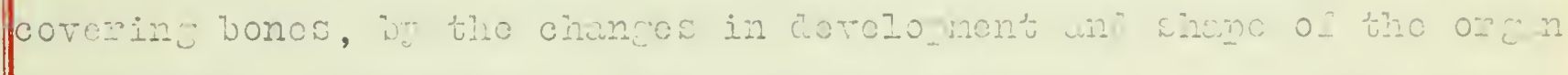

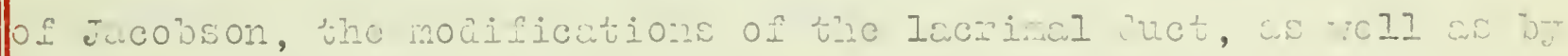

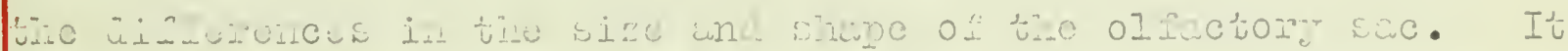

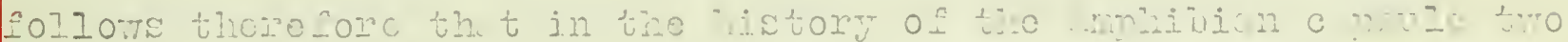

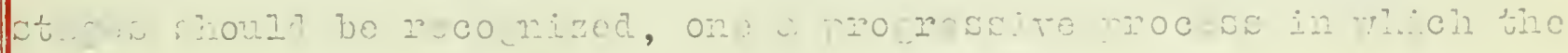

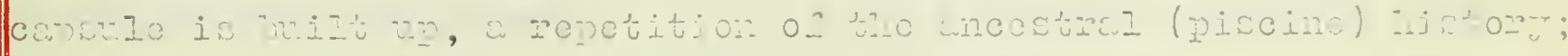

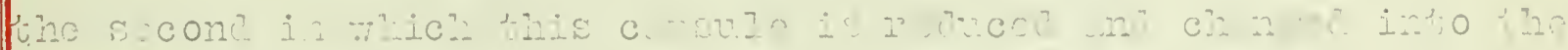

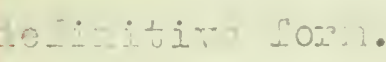

In IOInowin t?ose two st 



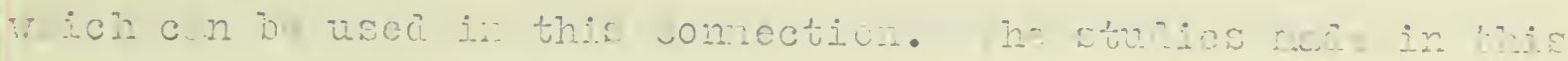

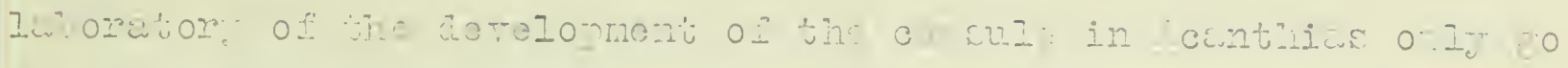

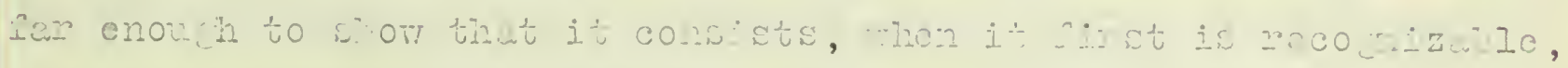

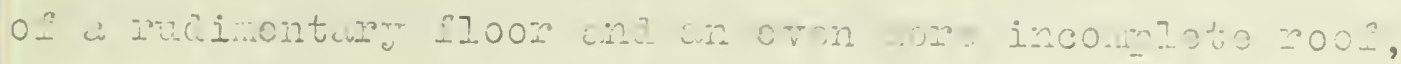

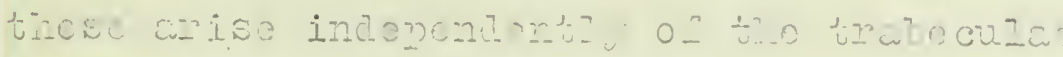

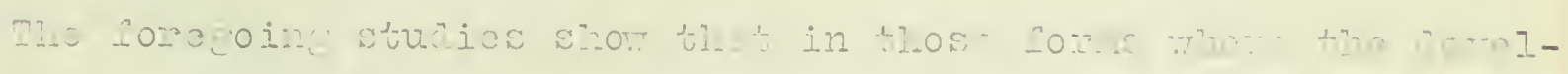

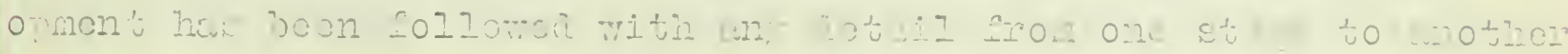

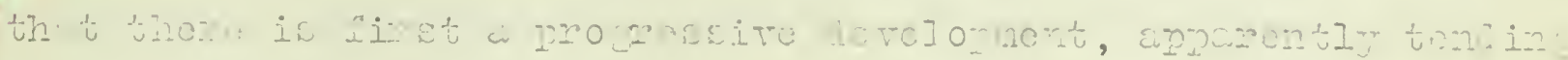

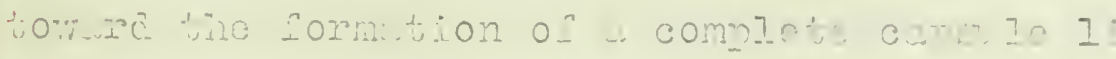

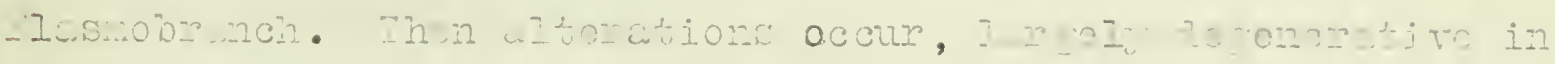

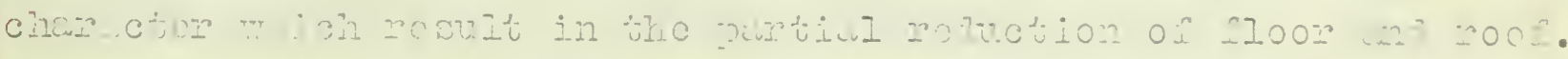

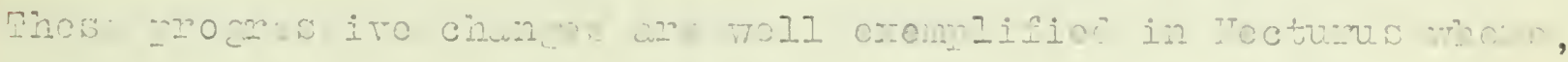

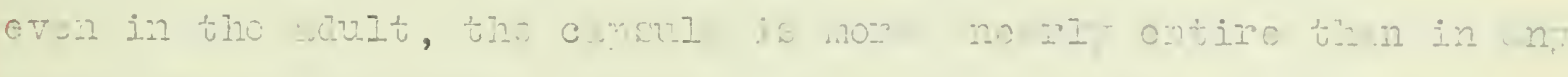

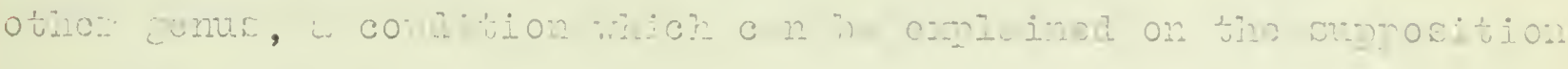

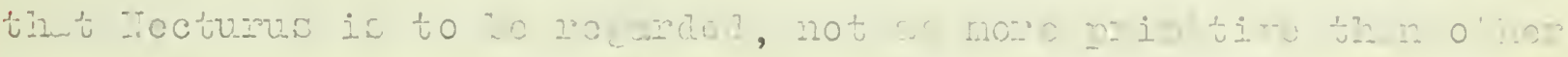

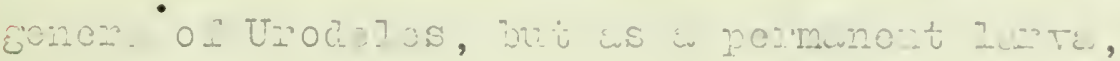

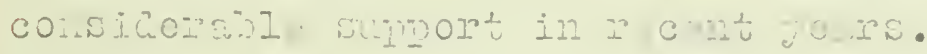

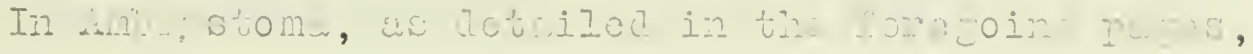

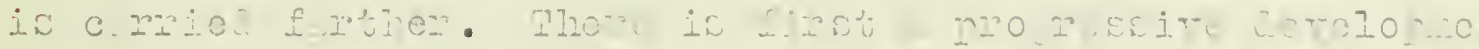

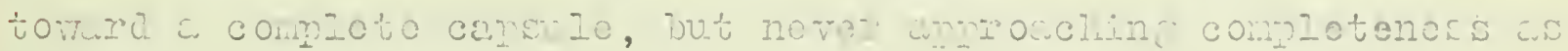
ne.rity an roos ITecturus.

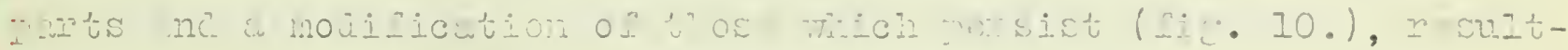

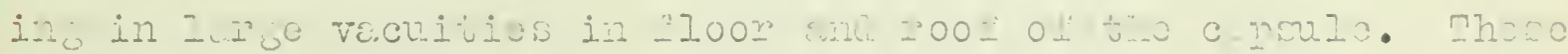

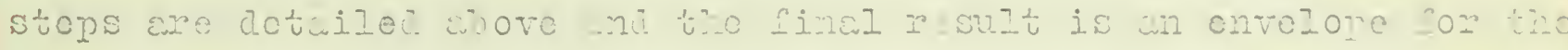

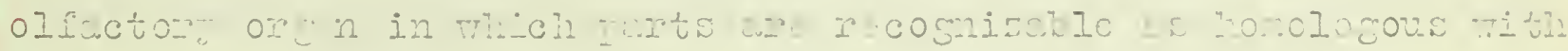

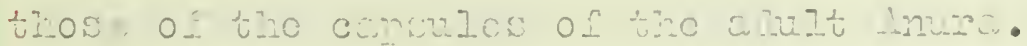

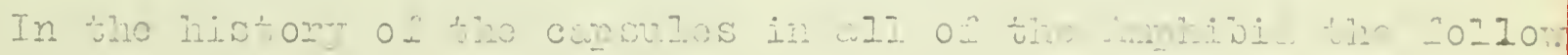

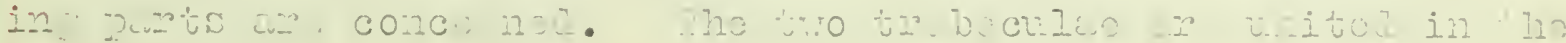





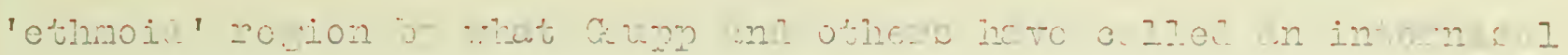

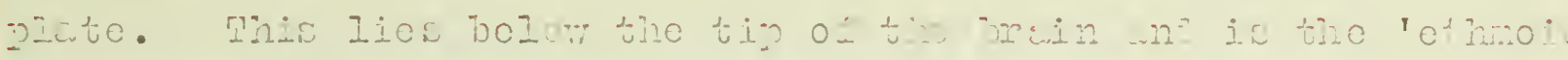

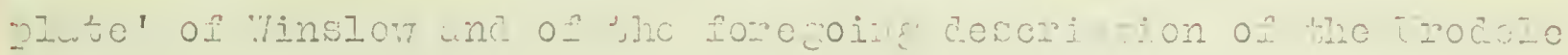

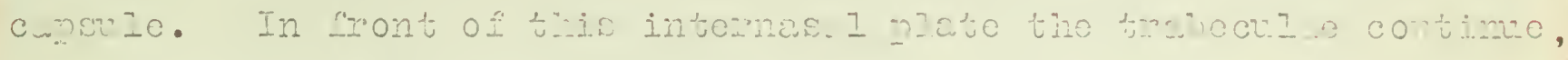

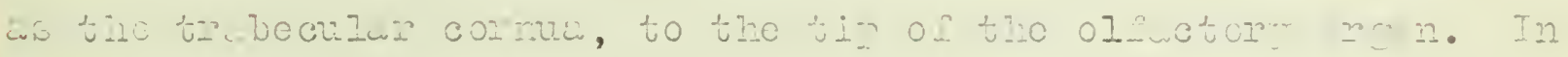

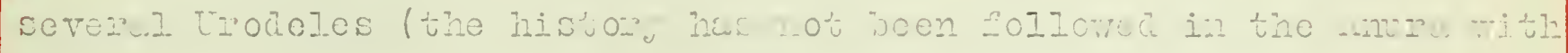

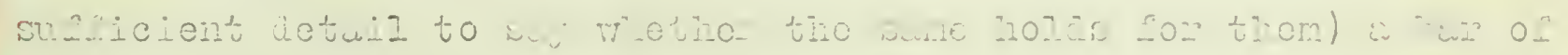

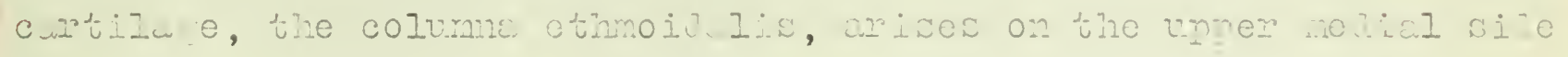

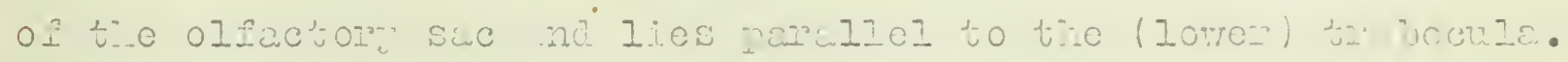

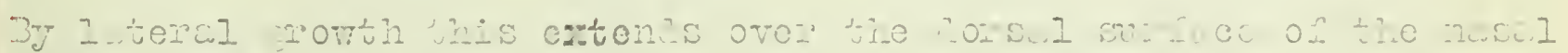

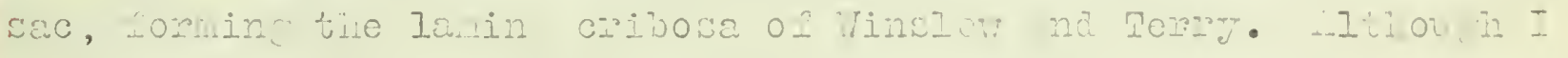

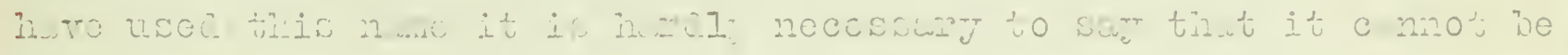

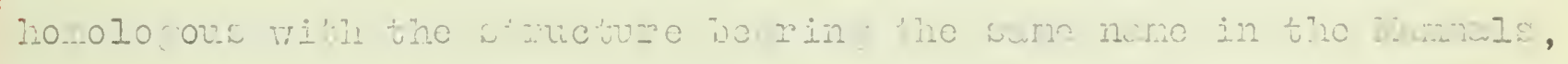

it lies wholz ond to the ol atom ne-ve. Pecturn nev lis

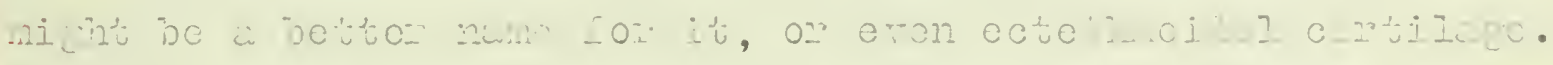

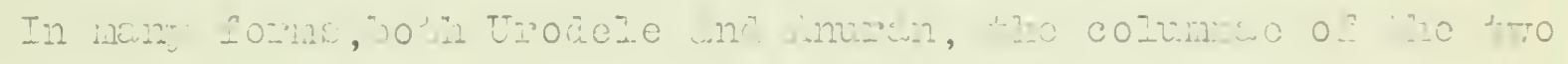

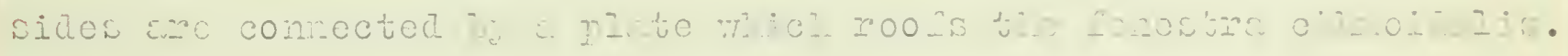

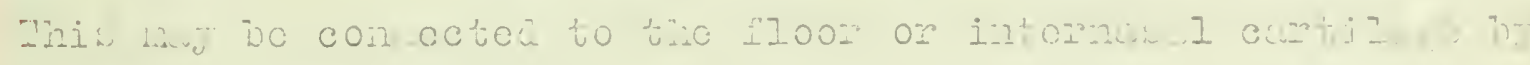

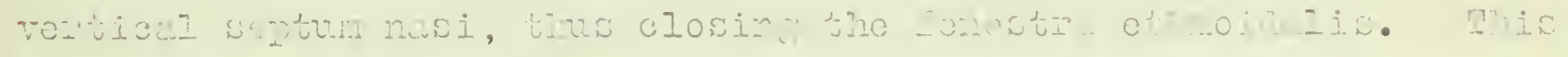

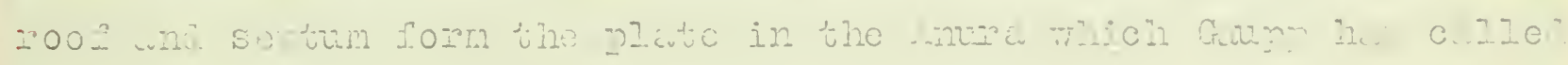
tile Iinum etraidis.

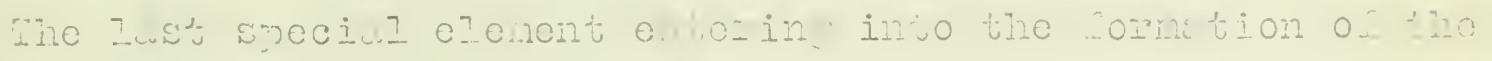

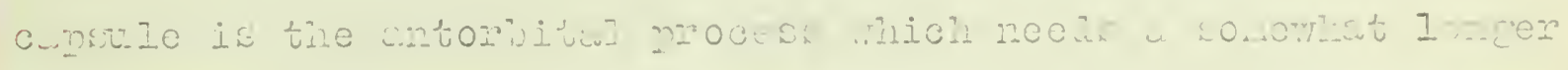

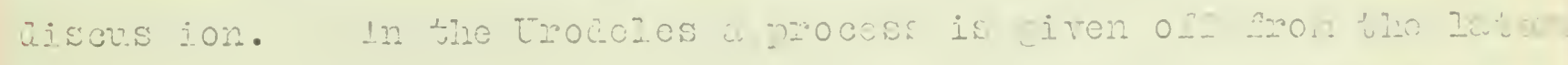

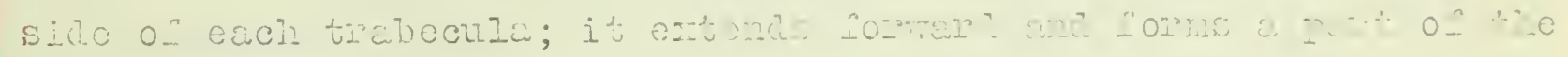

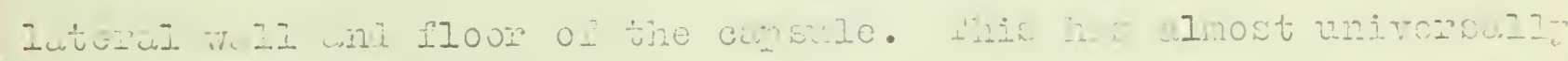

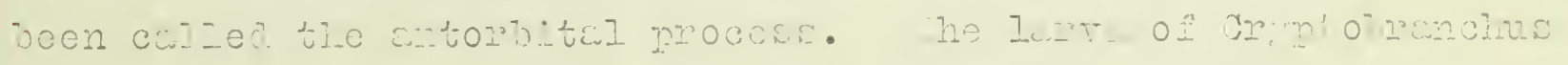

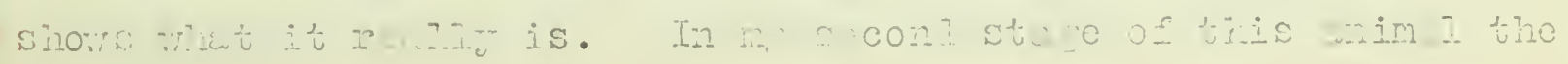





\section{5}

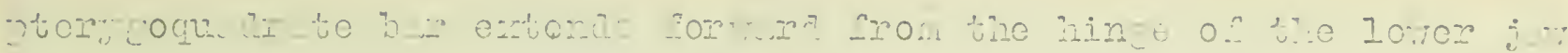

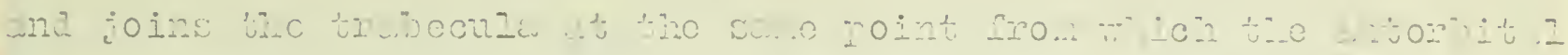

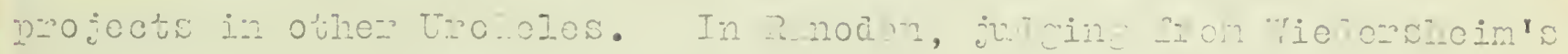
figuros (ro) (

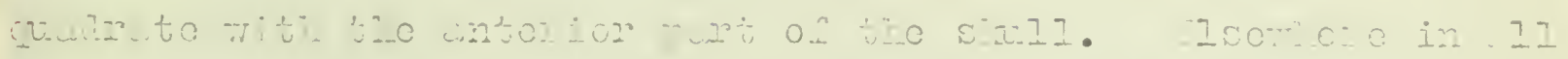
Rescrition Urolozes,

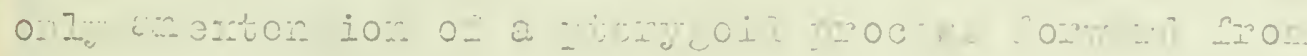

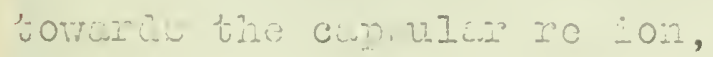

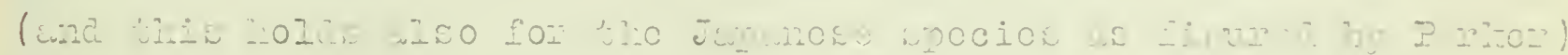

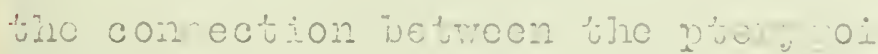

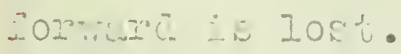

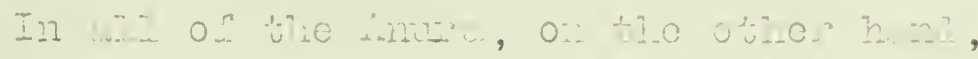

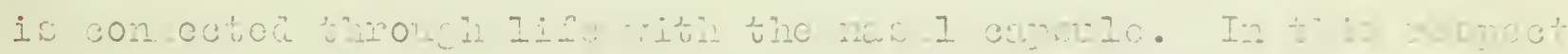
Réñocion

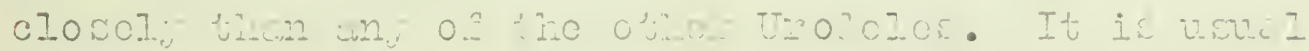

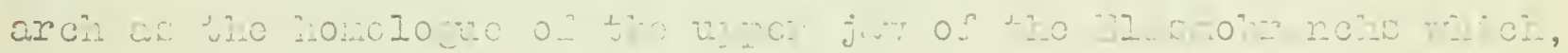

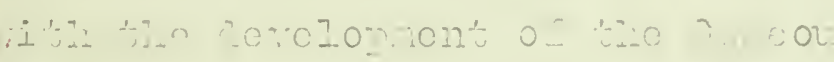

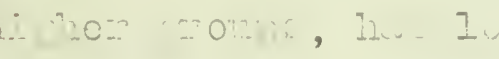

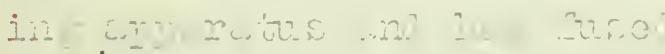

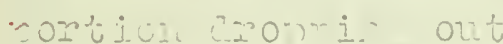

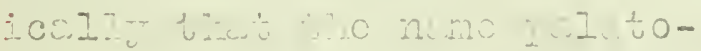

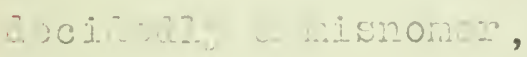

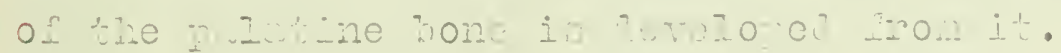

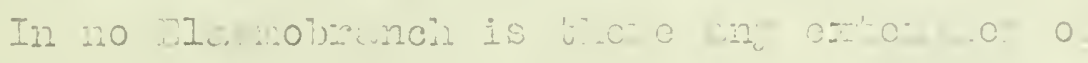

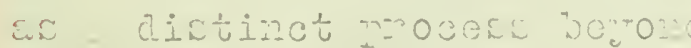

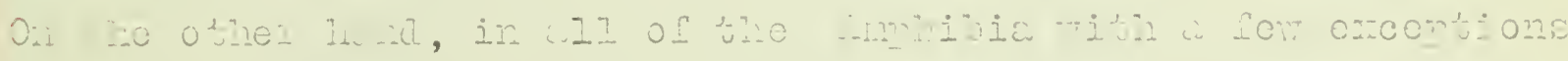

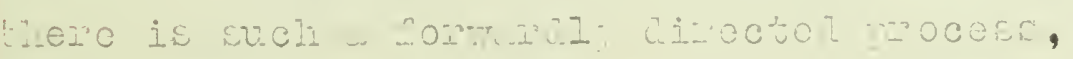

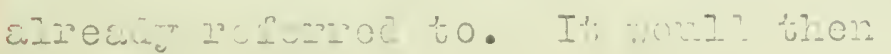





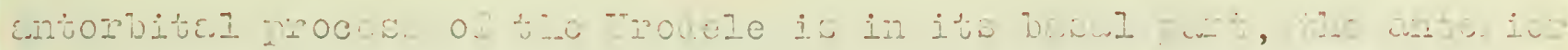

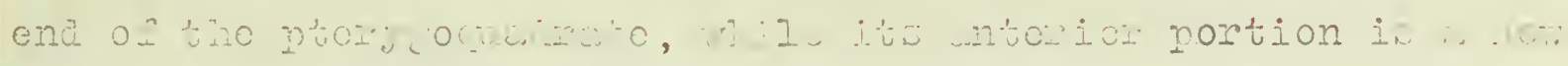

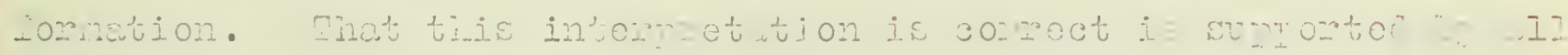

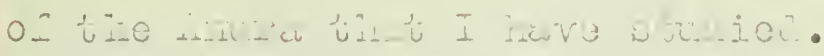

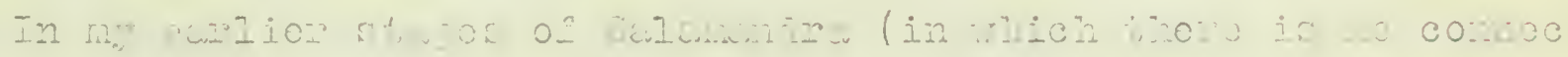

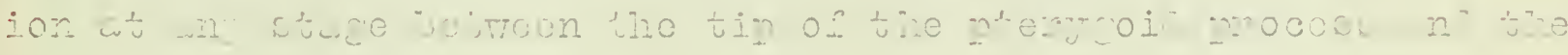

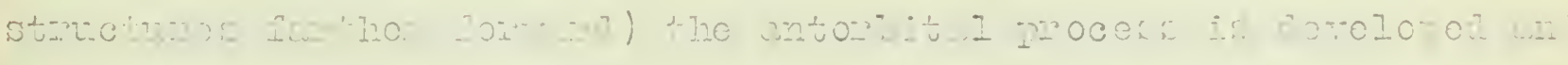

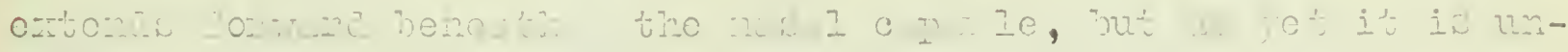

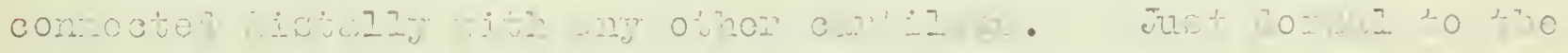

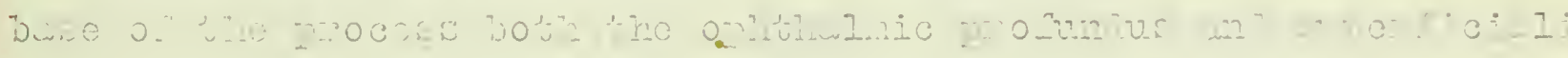

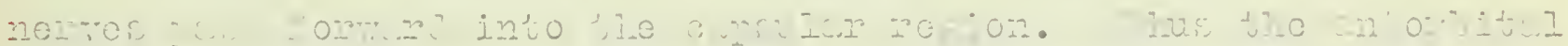

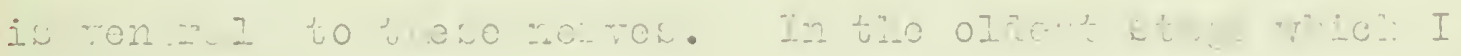

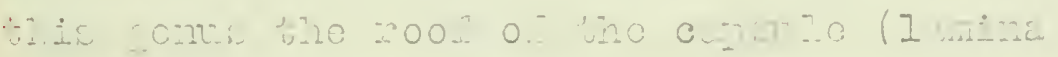
$B \operatorname{coc}^{2}=0$ Wis: $=1$ $\operatorname{con} s 0 \sin i t \cos$

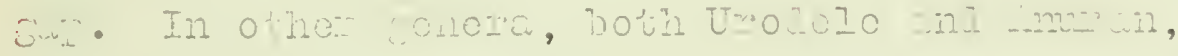

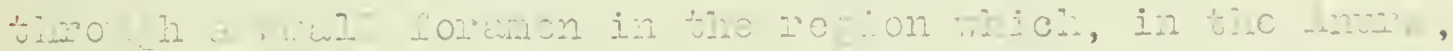

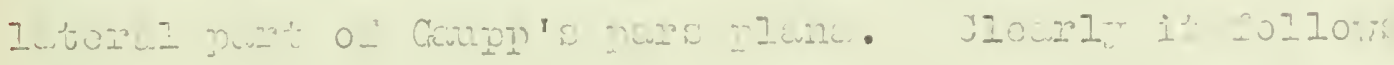

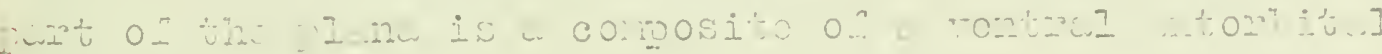
$\because 00=$ of tio cention

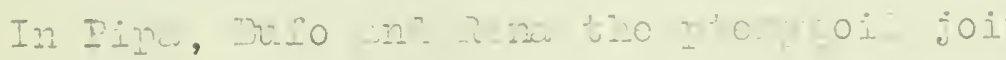

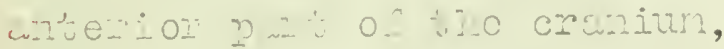

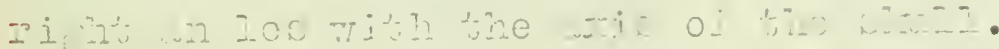

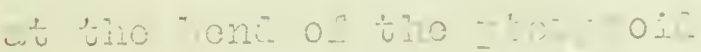

0 stoso- $0-1$

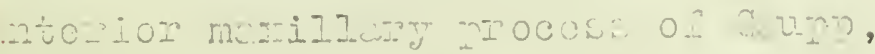

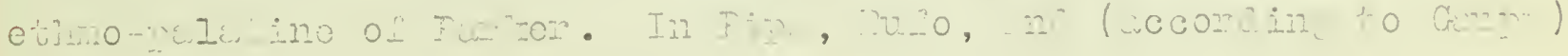

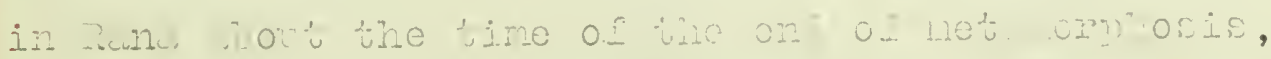



Which can be no other then the en of the wtorbital, is ioined, cithor in front (Rane, Dufo) or on its rentral surface (DiDw) by the postorior ond of the obli ue cartilage, the recion of the tunction forming a plute which Gupp has culled by the rather inar ropicute name of planum terminule, a part of the eztornul wil of the cande. In front this pIcmm tormincle fuses with wothor bur, tho vontral process of minslow, the recur ent trabocult of Danter. This ow extends formid to the tin of the snout, wiving off the lin w I lo-

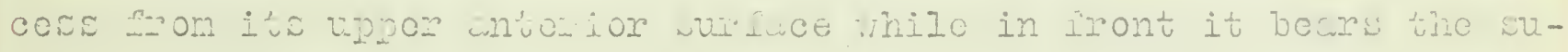

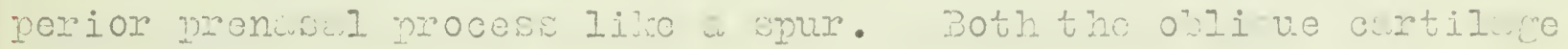
and this tentral bur we rerg short in bufo, their lenth wh andemosa mocressing in Pipe. I huve nothing decinite as to my belies that either the winwal process or he ventrul bur we to be ronned as a derivative of tho cornu troboculio. 

So nuriaons botrecn trodela an? "numa.

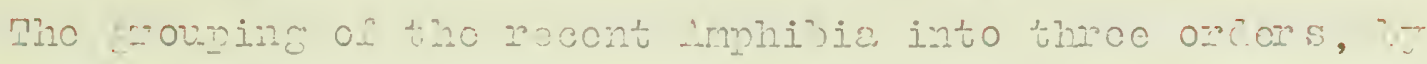

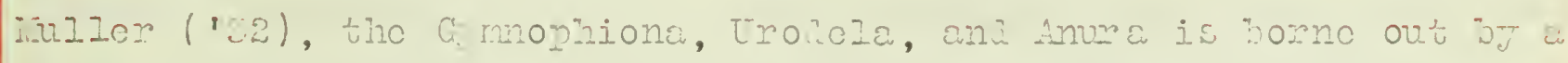

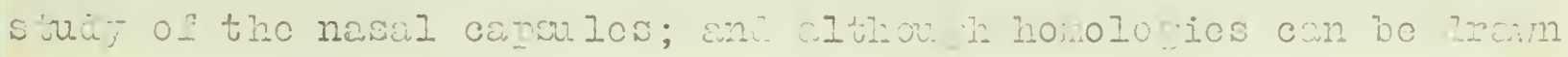

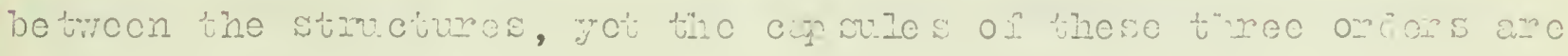
considerang difforent.

Among the Urodoles, with ono on two oxcoptions, ell larvae aevelop a compact nasal capsule woll chelosing the nascu suructures; but

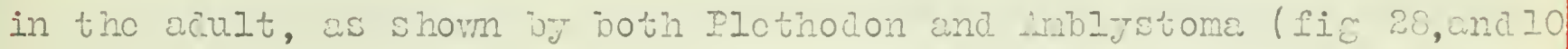
and according to Jom in the adult Irituon, larie vacuitios occur in the roof and floor of the capsulo. On tho oshon han tio inum pos-

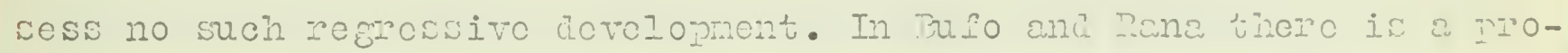

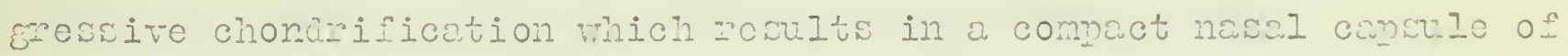
the adult doroid of cny lange vacuitios, such as occur in the tro clos. In othor worda, tho inuma have rotainod tho ancostral piacino charactor cron into the aduIt staco; mile tho Uroiclos, only in tho

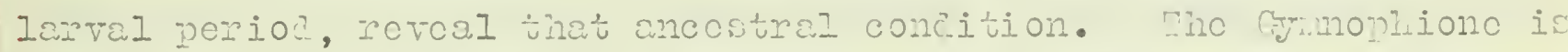

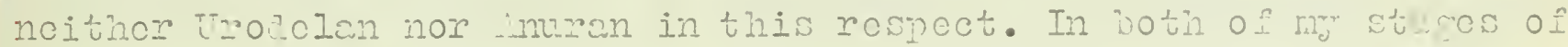

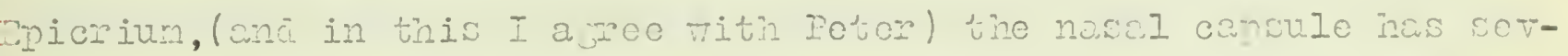

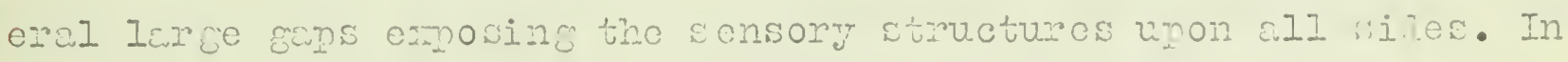

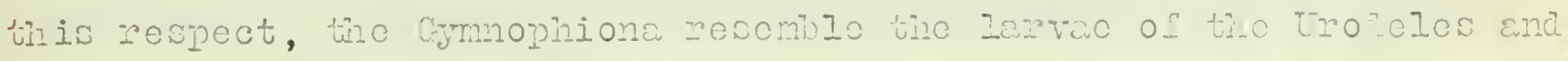

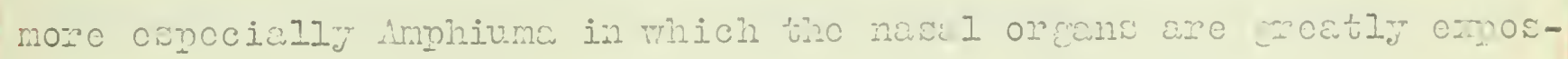
od, oton in m, oldost stuge.

In both Uroüles anc nura, tho derclopnent of the comile up to c. certain point is idontical. In both, the trabeculac fusc in troc medicon line to form the intornesal or cthnoid plato, and unon continue anterior to it as tho comua. Also, tiro ctrnoidul columes dorolon 

in connection mith this nodian plate, we by nolial gro the forn tho

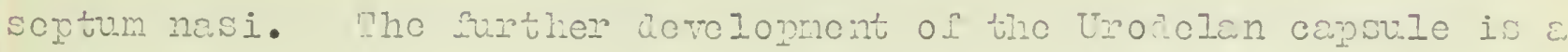
Eowth of structures cilreañ formea; while in tane, wup has descrio ed several independont chondizications. Acorline to Parter, the

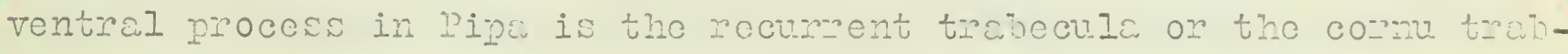
eculae of trodoles; so that tho solun antorius of thio, with thich we have honologized the ventral procoss in Dipa, way bo compered to the Urodolan cornu trabocula.

In the Gumnohiona, I hate no eviance of an cthmoidal colum, neither coes the ierclopnent of the capsule aroe with that of the Urodele or muran. In the prosence of dorsol uad rentral trabecular

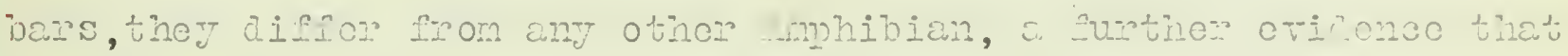
this order rimst be widely ronotod from the othen goune.

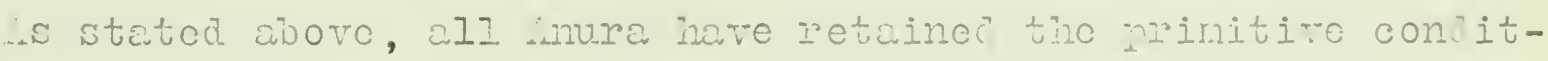

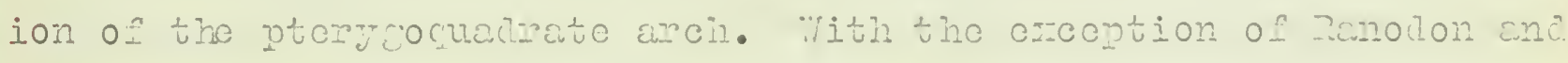

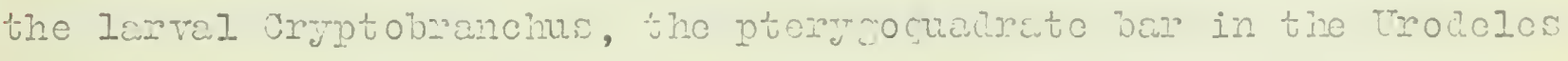

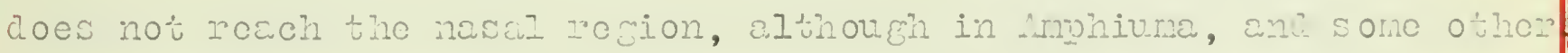
it closely aproaches it. 2t the place in the mura, whore the nú ruy goid procoss joins tine trabecula, all Urollolos hato in chtortíal procoss, thich, as shom by urptonrenchus, is partially ptomeroical in charector. The conterior part of the cuntoriten procoss is an whitional worth, and is the probajle honologuc of tho muran plonun torminale or antorion naxillary procois. The laning cuibosa of

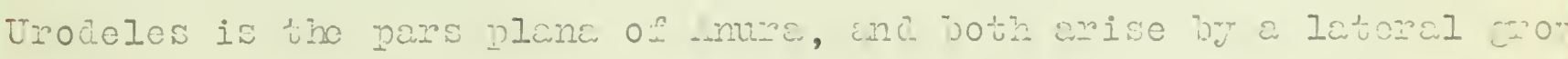
th of the otimoidal colum. This homology appeard tho moro oncti when we consider that tho nerves of the nascl rocion entor tinc car-

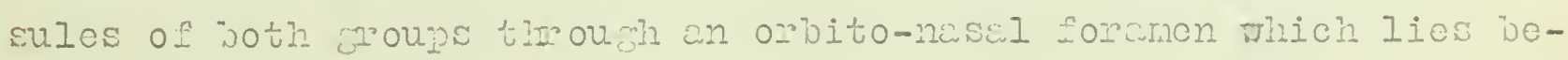



troen the antorbital(ptoryoid) and lamina cribosa(para glana).

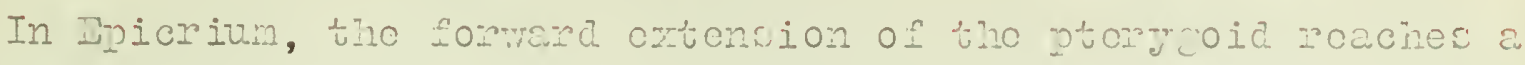
condition alnost whun. Thore is no functional wntombital paocesa

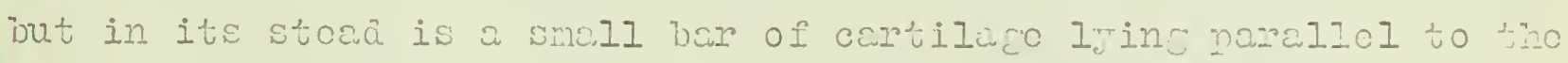
ventral traboula. Tust posturior to this bar is the an'serior one of the ptorycoic procoss, and I an inclinoa to bolicro that theso

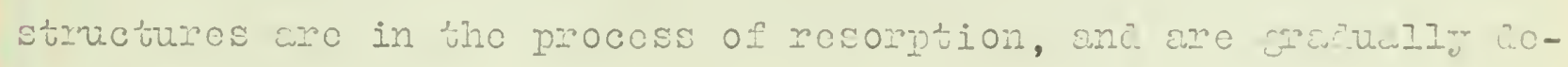
partinf from ancessrel concition.

Gumophiona and Uroiele nevo noishor a nosal toctum nor a wolun nasale, so that in tho ciult ategos tho sonsory ormans rest upon

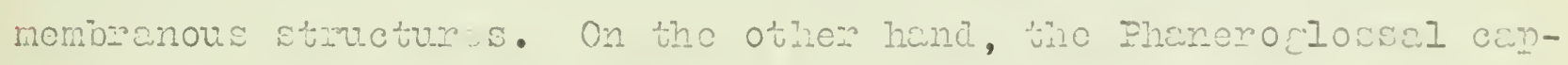
sule has a wll chondrified roor and floor, and adcoucto protection for tinc nascl sacs.

The rolation of tho contral nortous syouen to the nasci orens

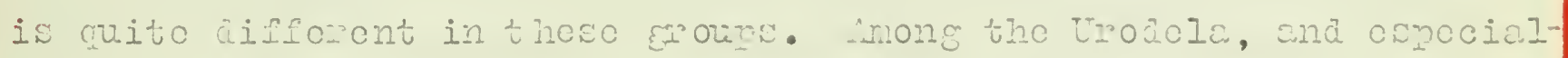
ly the lartil stegos, the brain extonis troll forward botween the olExctory oreme and lies latoral to the postozior three founths of the nasal sac. In the culult troieles, rith the jeveloment of the

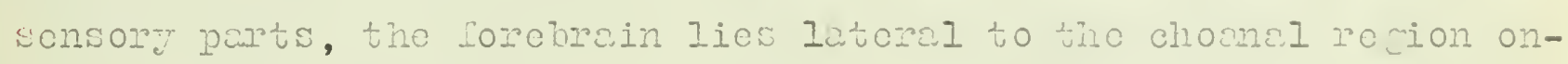
Iy. On the other hanu, in the inure, cortiling complotoly sename tho sonsory parte from the forobrain, which lios ontirely posterior to tho nasal saca. 



\section{IZo:Sizicuín.}

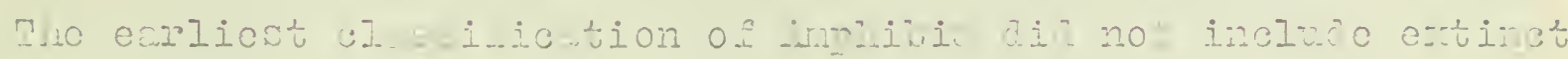

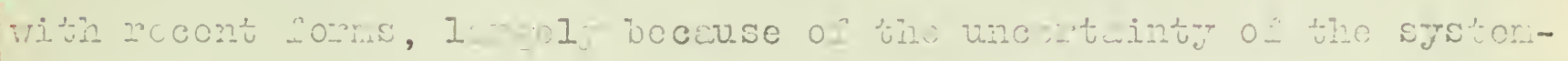

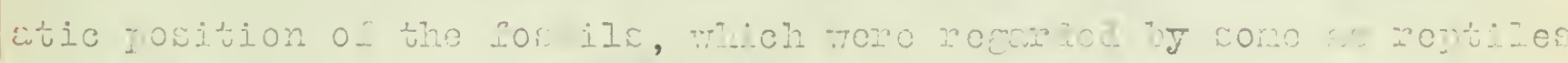

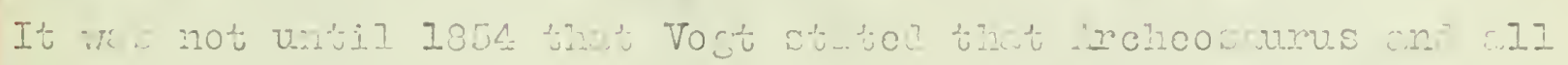

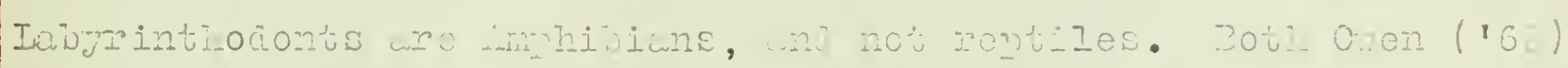

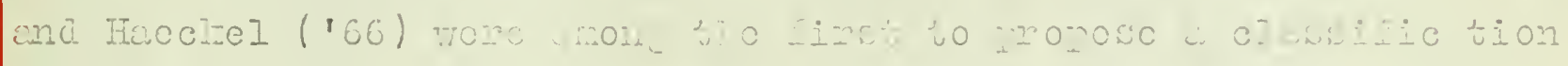

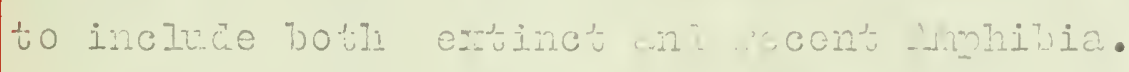

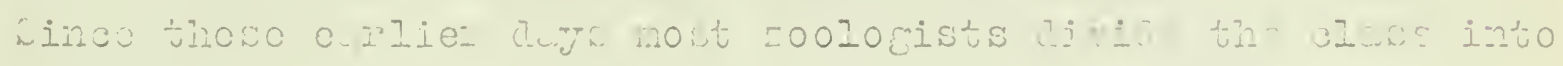

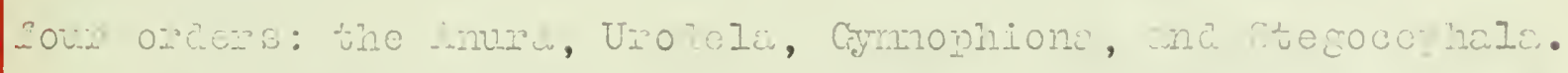

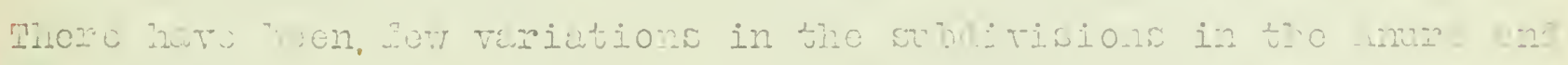

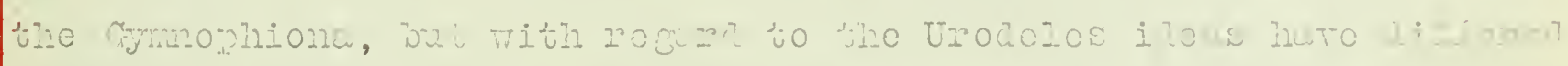

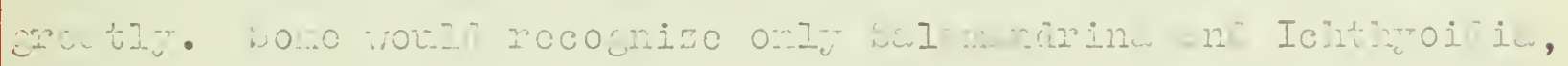

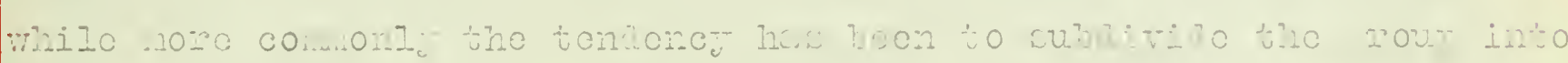

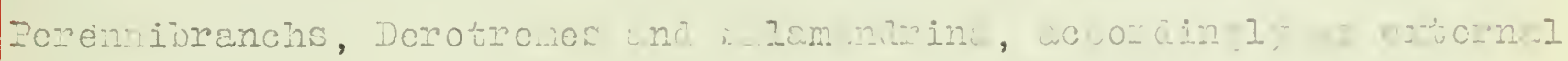

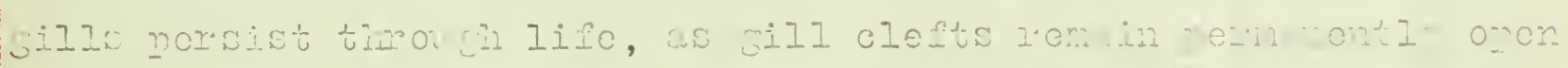

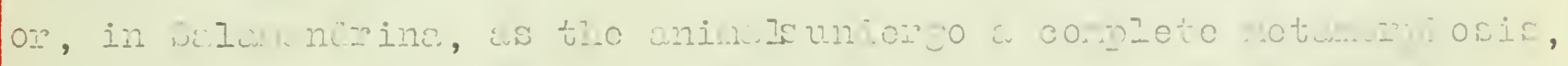

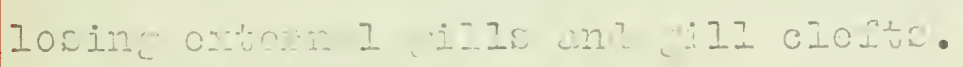

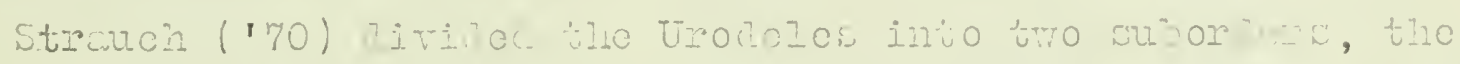

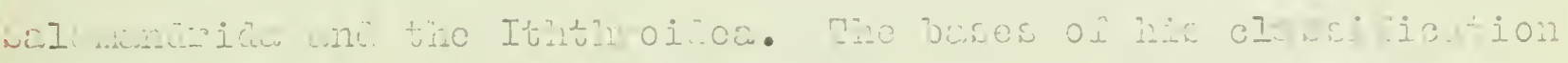

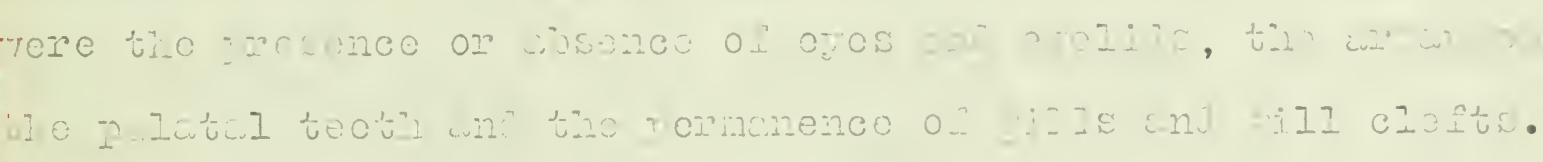

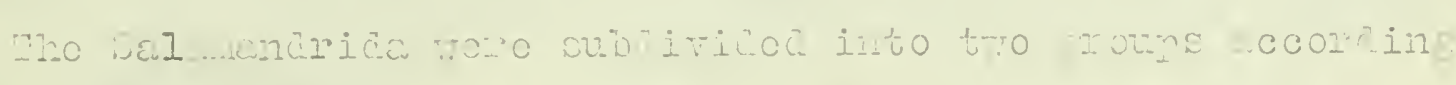

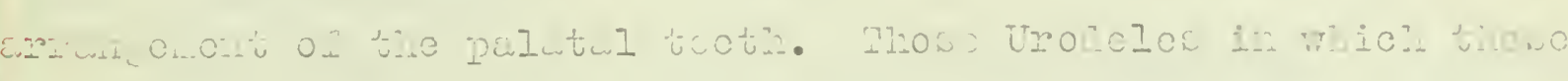

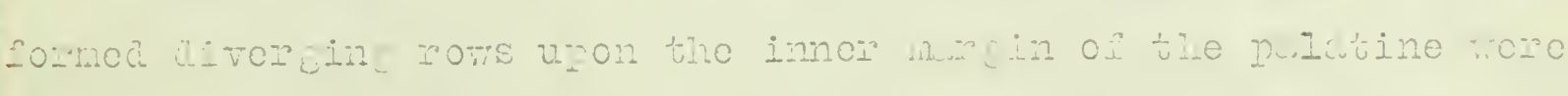

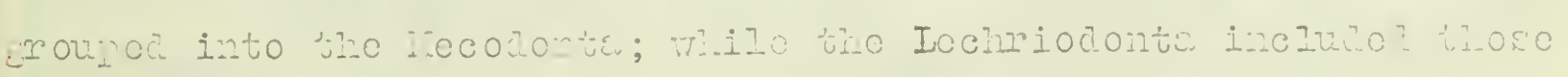

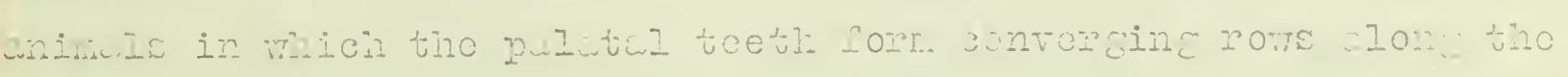





\section{2}

postorior Iurgin of tho palatino.

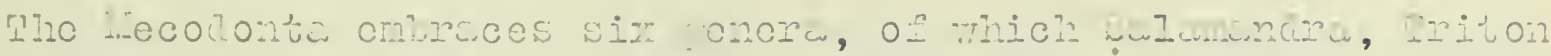

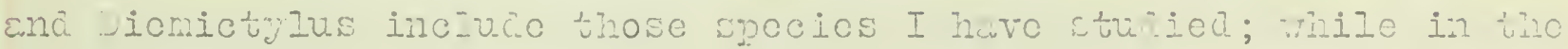

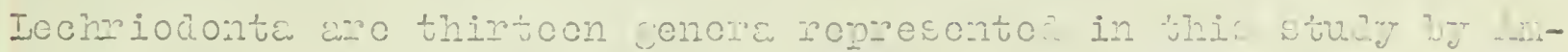

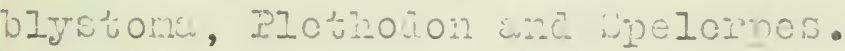

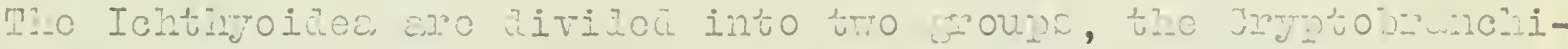

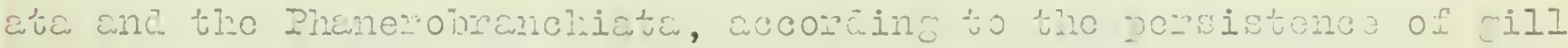

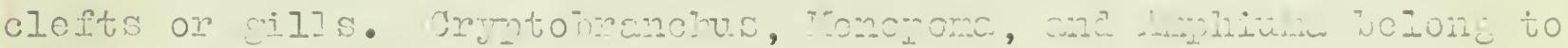

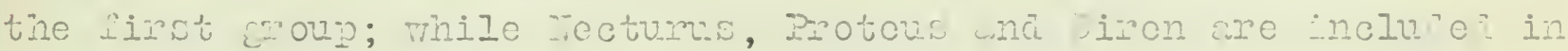
the sceond.

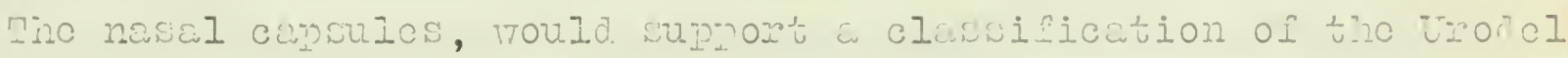

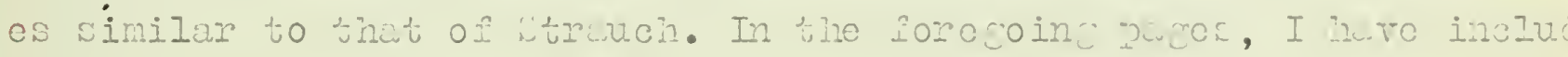

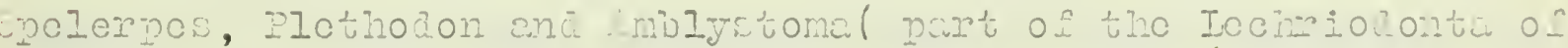

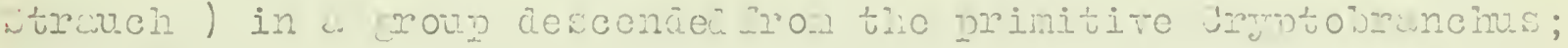

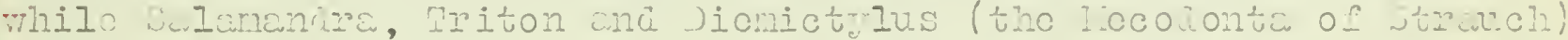

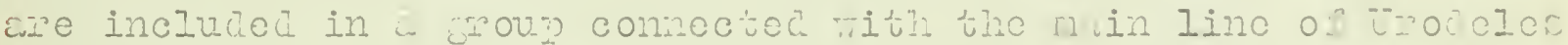

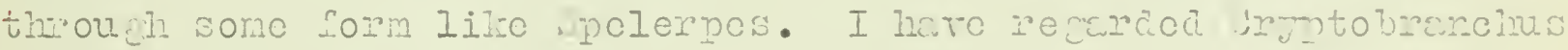

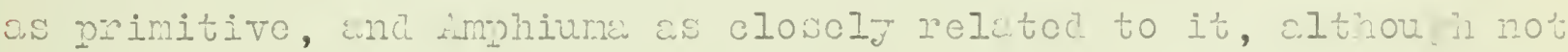

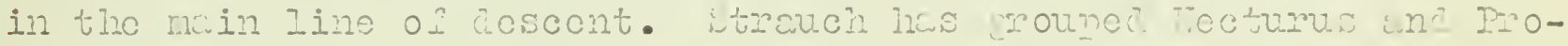

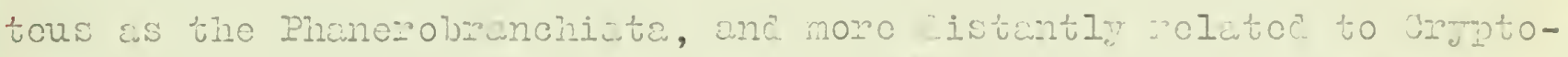

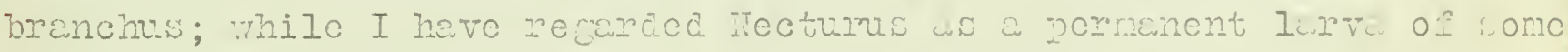

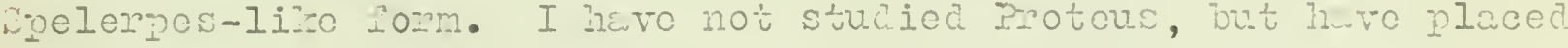
Irecturus in a seperite group in "eoping with tho later Poronininanchicte cIsasifice.tion.

iccordinclu, on the besis of the nescul capsules, I rould saneze to the classificction of Urodolos into trroe subordors, the Poronnibranchiata, Jerotroma, and Balamendirina. The Salanendrina nay bo

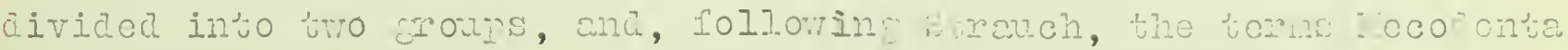



and Iochriocionta mat be retainca.

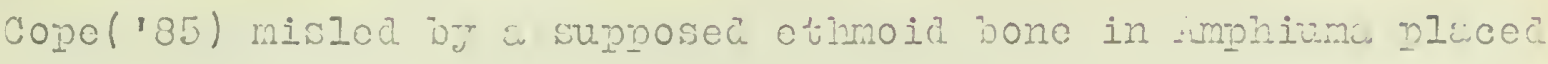
the Gymophiona into ce fomily of tine Trodele; in whioh ho wcs luter

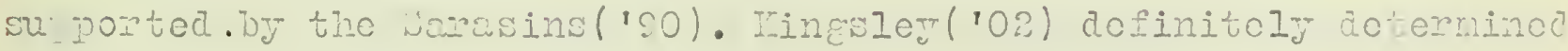

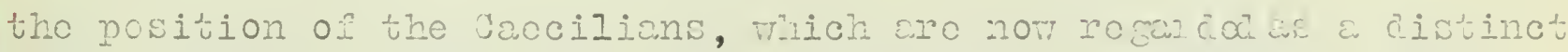
order wh which probubly separetod from the other minibia becis in

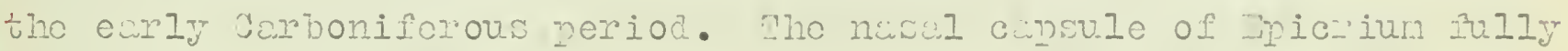
Doczis out tinis conclusion.

The murain capsulos aro roacily separatod into two æoups which afroc with the osveblisheu classification into the subor cre

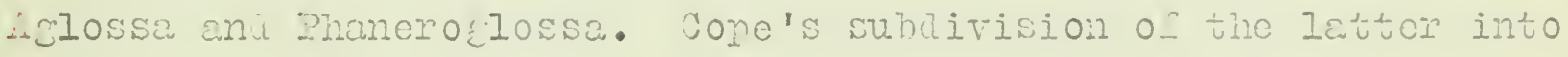

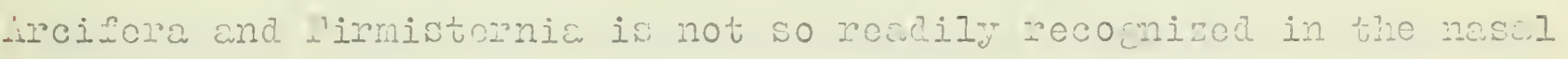

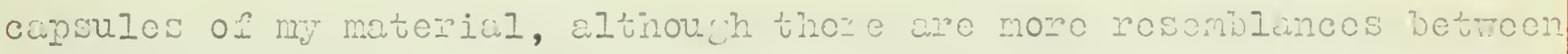
the capsules of ufo and Ityla, then of either with that of Wua. 

The mpioians anean, as stegocophals, in the jarboniforoun period, sne althoumh at first thor ane considenuby diversiaicd, there is not lmom a single trace of wh letrapoious vertebraie in the jevonian with the wole excoption of a winte sootprint firom Ponnsylvinia. In tho Devonian and somerhut carlier ainos WeIoneing both to the jipnoi wh to the Grossopterm. in ennoids occur and.

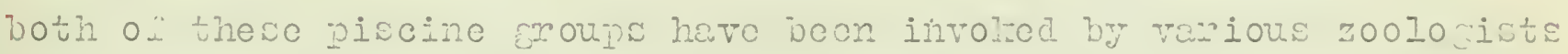
ws the cncestors of the mphibic, possibly the tentencr of the eridence at present favoring the vrossontergrians.

LII of the cmphibians of the cerboniforous, with the possible exception of Pelio, wero caudate. Hoocie, the latest to stuar thoso

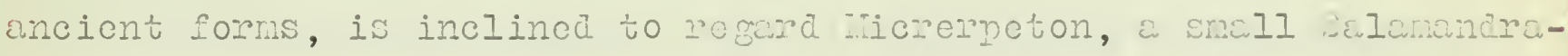
like form, de reprosentine the ancostors of the m aern grouns with Tecturus as an wneotant conus. JTe Dasos this conclusion unon the

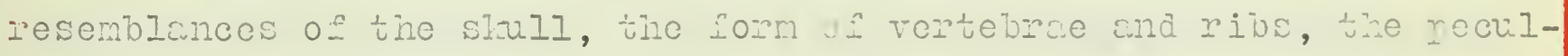

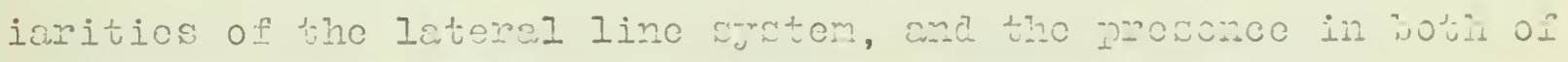
"vontral scutellations", cu viom which closelJ resomblos the cunlion ICCcus OI CODC.

But it mould soem an il moolic wis Icaning upon a rean lood in involrine ventral scutellations as an wreumont, no mattol what

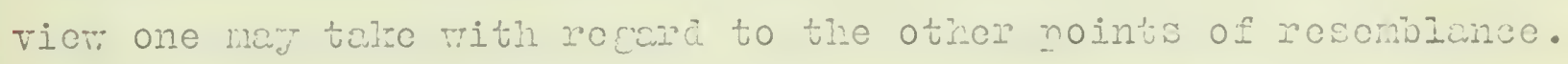

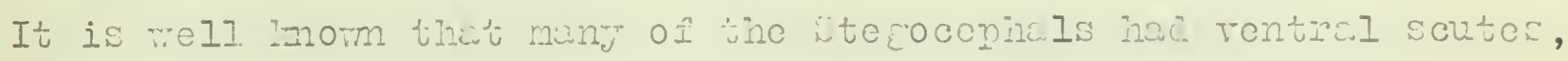

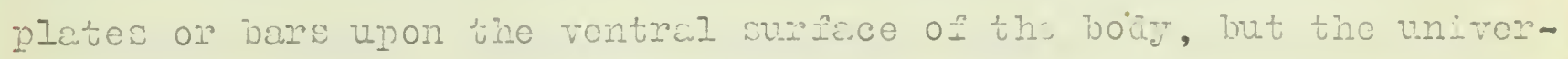

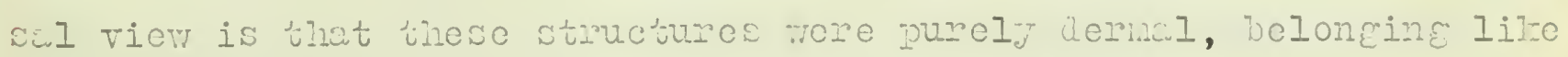

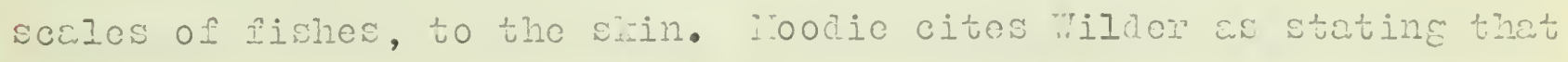

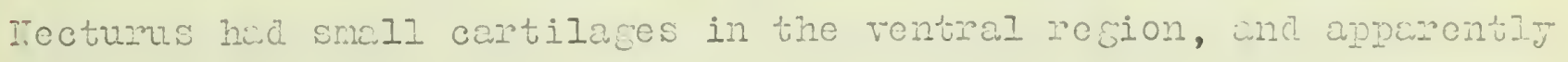
he reguras these as the homologues of the ventral curror of stogocoph- 

ald. Wut there are very imortant differches betwon the trro.

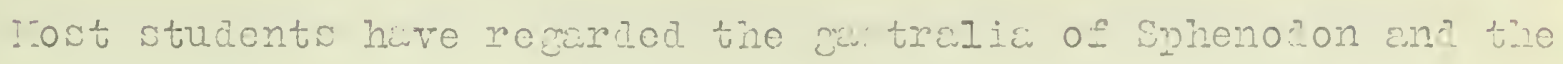

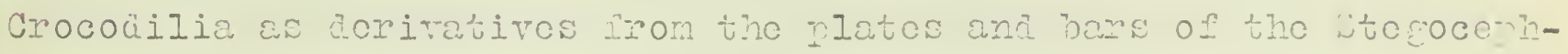
als. Those Iattor are also sugeotod as forning tho olements from which the clavicles of the hichor vertebretos are dorived. In

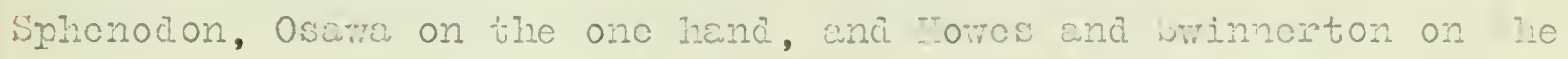
other, tho custralic are statod to dovolop without ane cartilage basis, wnd, with tho single exception of Schneiacr, no ono has ascrib-

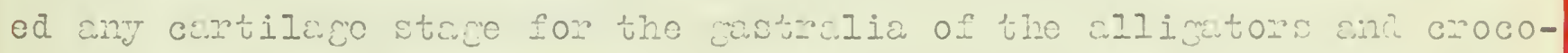

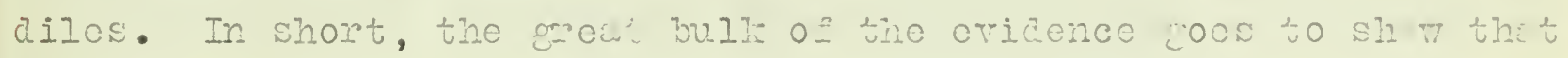

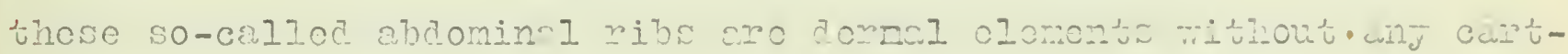
ilsge stage.

Wilacr orplicitly statos thet the curtileces he loscribos in the rential surface of trecturus lic in the mocometa; that is, ontirely doopon thin the arin. Ile compros them to stemal elenonts. Hence it moull appour that othor oridence thon these intormacular cartil gos mat be brought aromed to support his thosis.

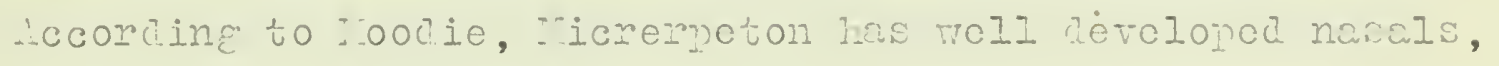
frontals and clonguto musilaries, wll of which wro lectring in rocturus. Hom is lecturus is to ropresont tho ancostons of the morem Urocielos in which these sune clements wo niesont, we he to the difniculty of explaining how those bones discmperied from tho line of dosc nt and then were reformed in the later gencrations,

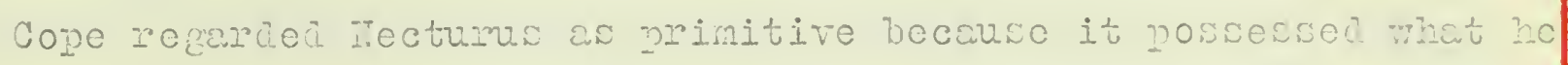

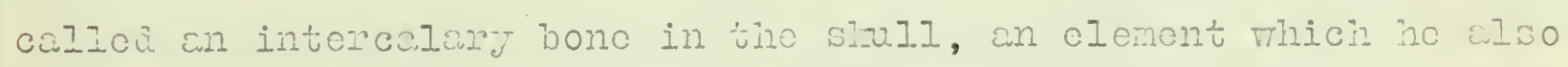

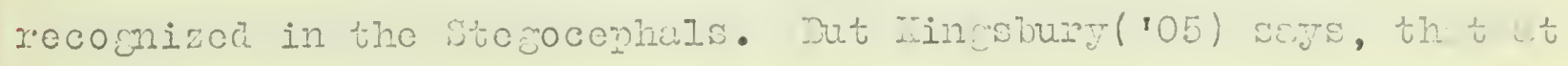

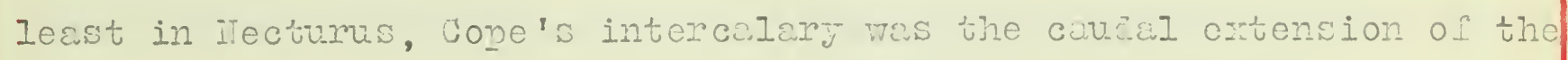
opisthotic. 



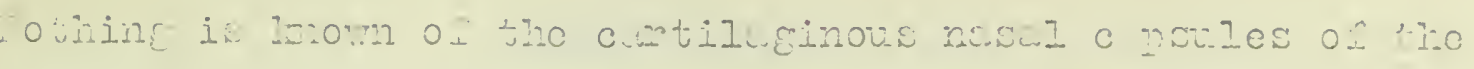

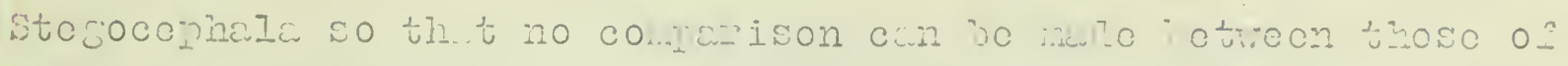

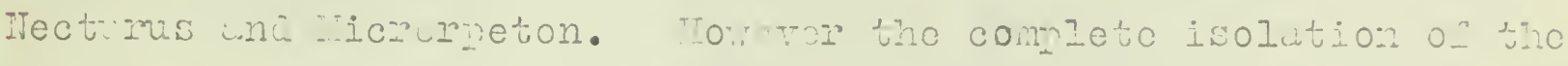

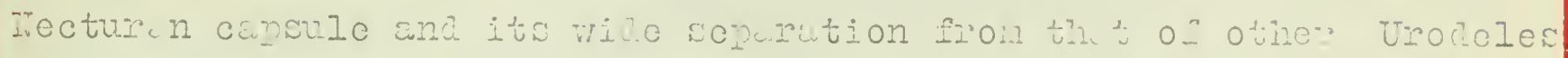

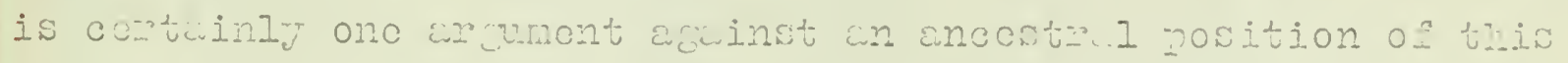
Urodele. Wurthomoro the wionence of maxilzariea, nescls, une pro-

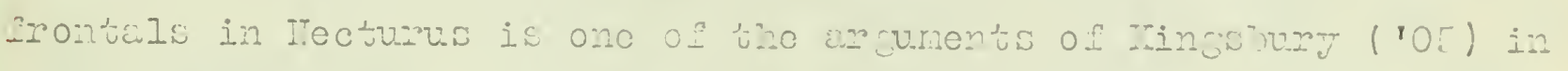

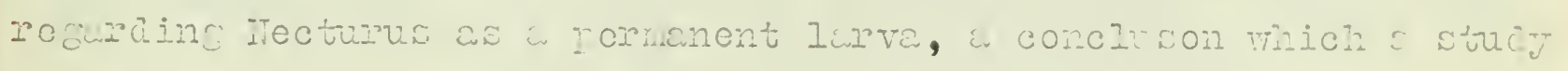

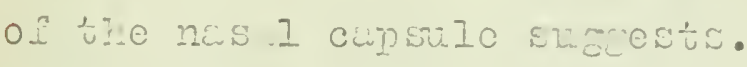

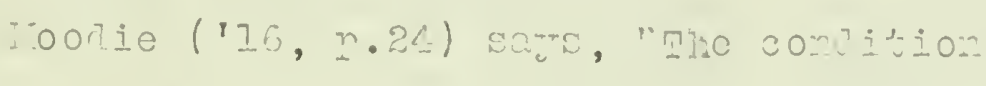

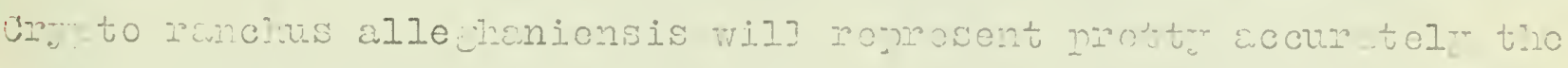

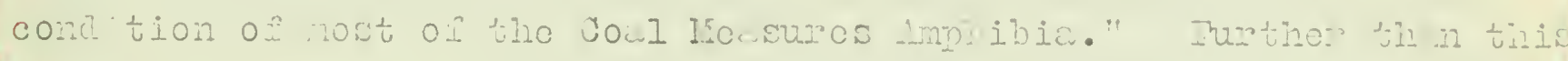

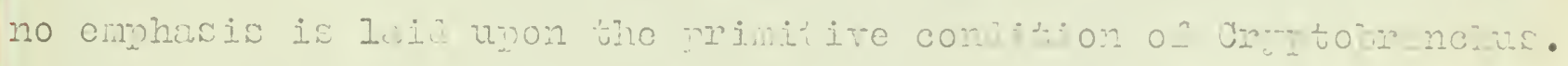

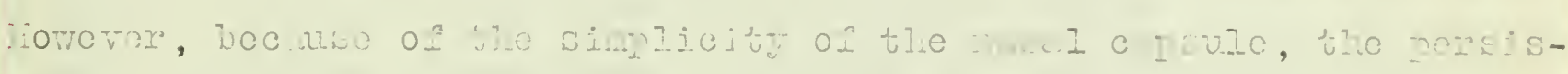

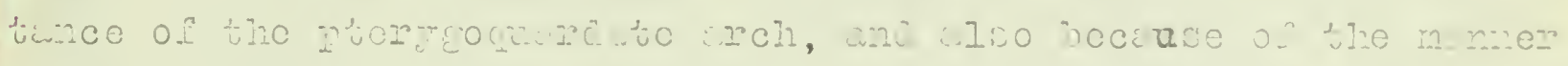

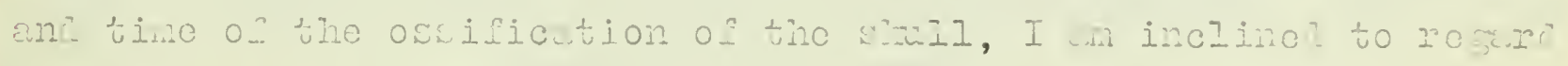

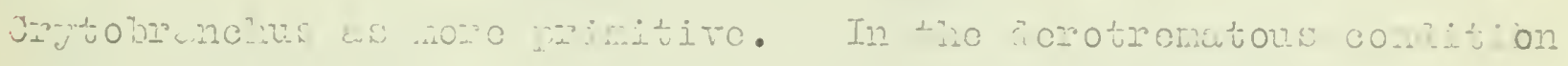

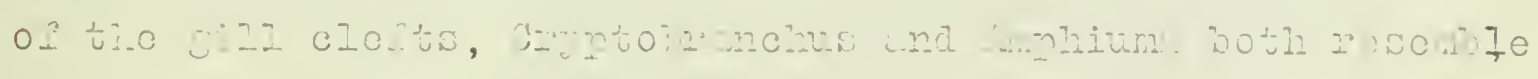
itegocepherion comitions.

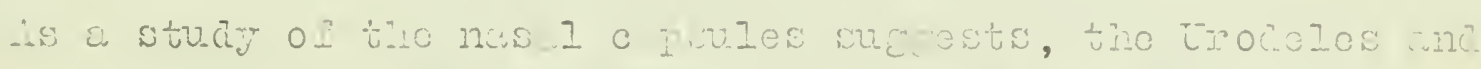

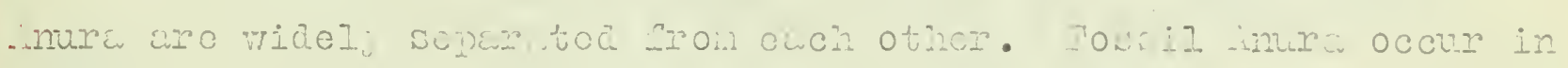

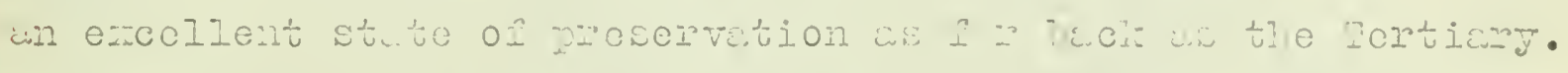

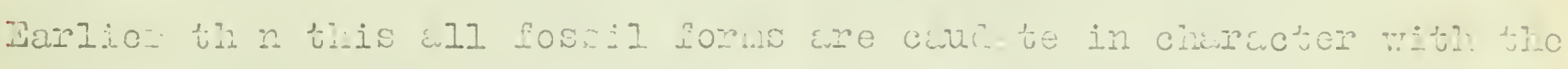

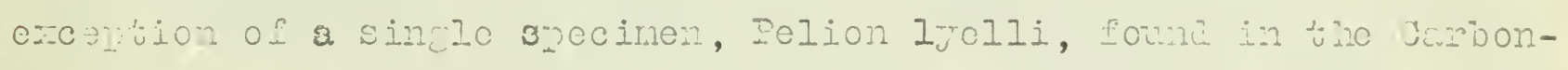

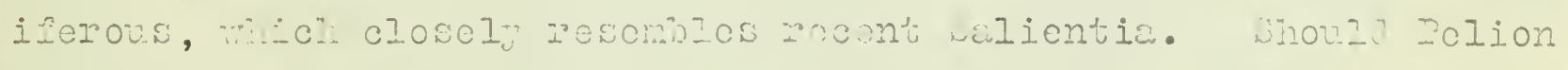

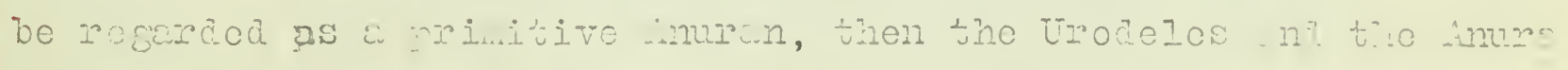

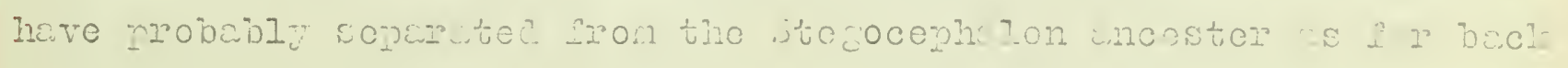

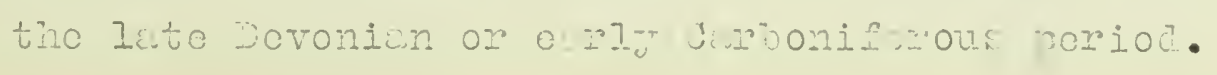





\section{Bìlionanit.}

rgr - Buncroft, I.:. ,

The Tasul Oreurs of Pipe ancricuna.

Bulletin Jissez Institute. O1. $67,1827$.

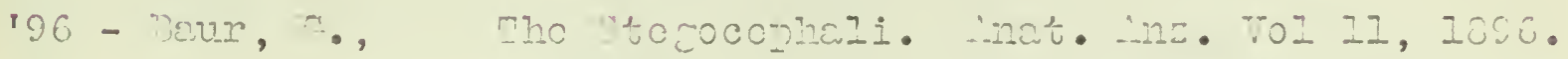

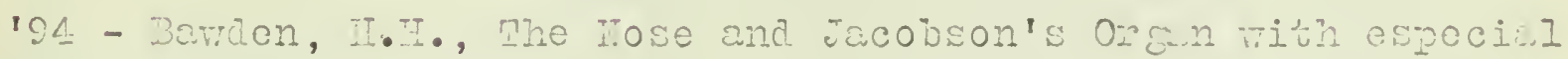

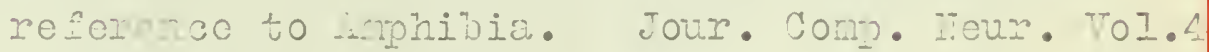

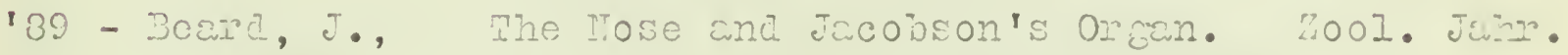
abt. wur inetoric unc onto fenie.

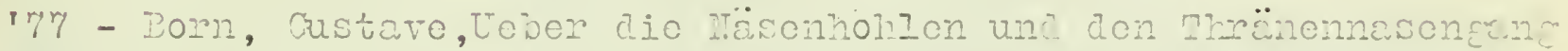

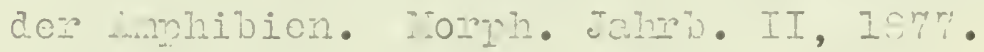

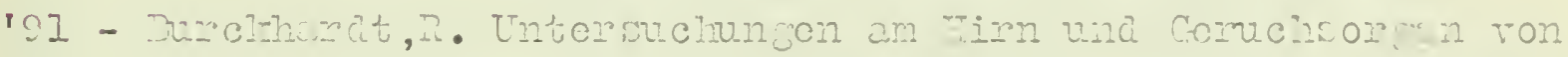

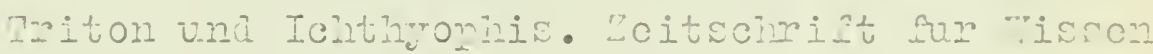

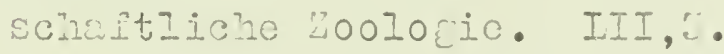

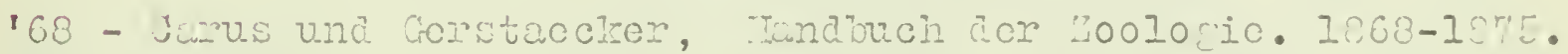

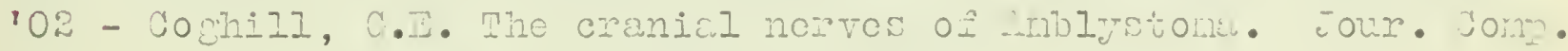
ITCUI. TOI. In, 100:

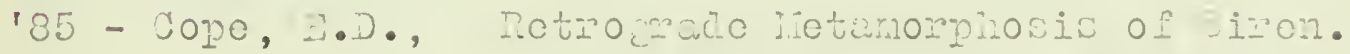

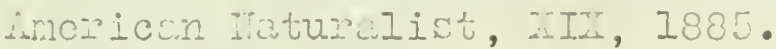

$186-$

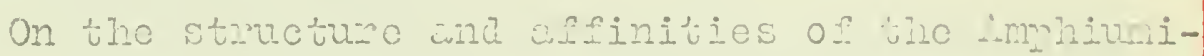

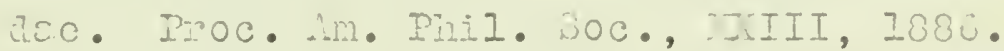

$89-$ The Jatucohia of Tordh imorice.

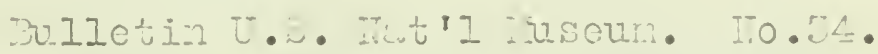

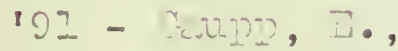

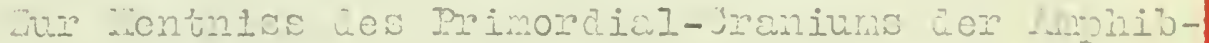
ien una Re tilion. Torhancil. e cuat. resell.

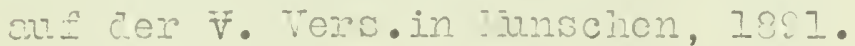



$195-\operatorname{Geupp}$, D.

Beiträe zur :orpholo io ces vidinels. Frimor-

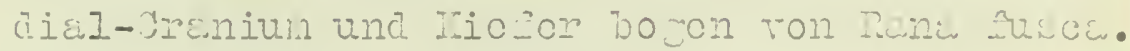
roppli. inetton II. 1805.

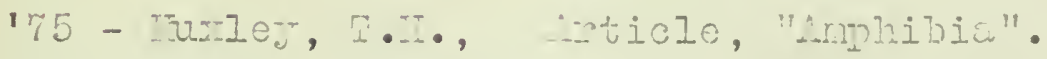

meyc. Jisitan. Tol. 1. ninth eni兀ion, 187 .

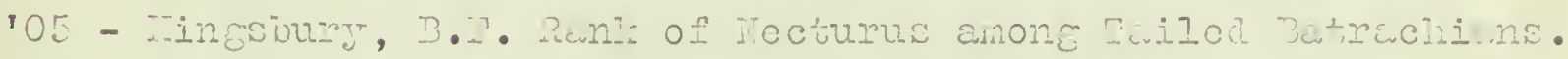
Tiol. Ju.1. To1. 8, 1505.

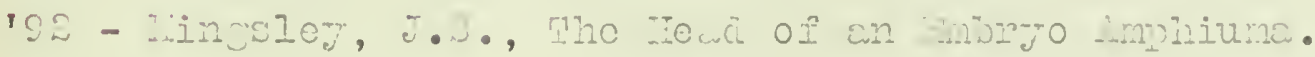
Aner. IRture, Tol. 26, 130天.

$102-$

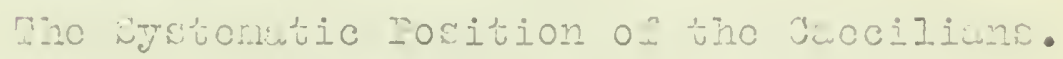

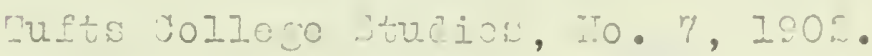

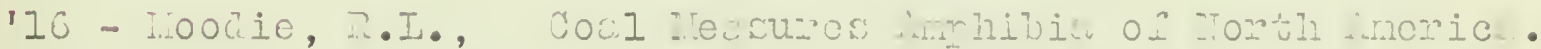

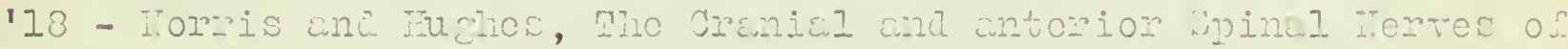

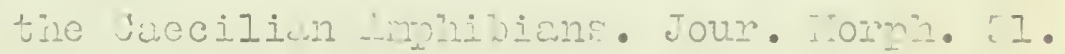

$17 z-\operatorname{Lin} 20$

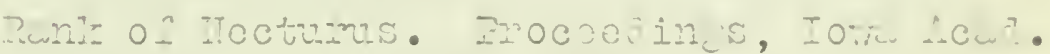
OA beiclice. Iio. 23.

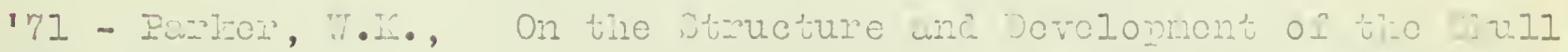

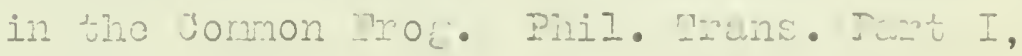
Vol. I6I, 18\%1.

$175-$

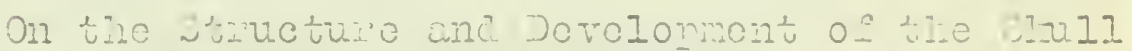
in Datrachio, II. Mooc. noy. Dooy. Ionün, 26,1875

$176-$

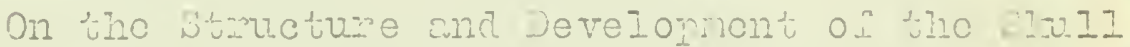

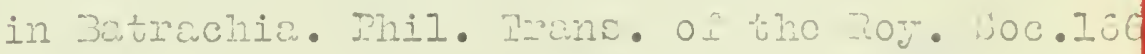
$132-$

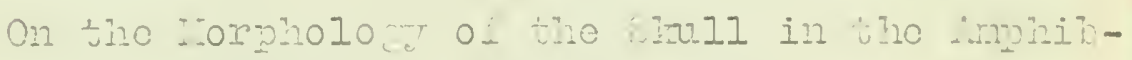

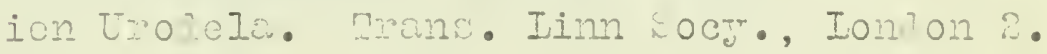





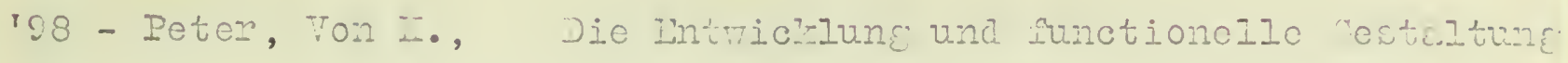
des wchïcle ton Ichürophis Iutinosus. jomp. Jains. Tol. 25, 1828.

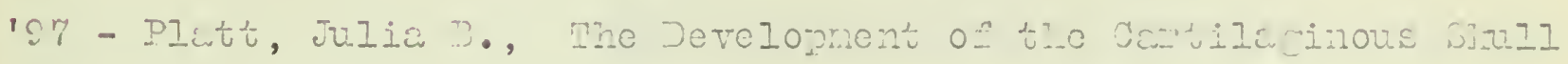

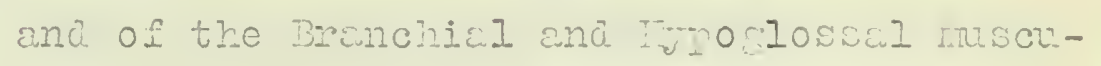
leture in teoturus. Forph. ouhr. Tol. 25.

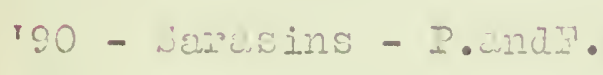

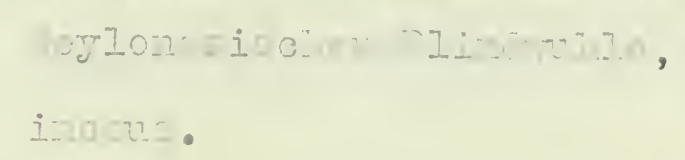

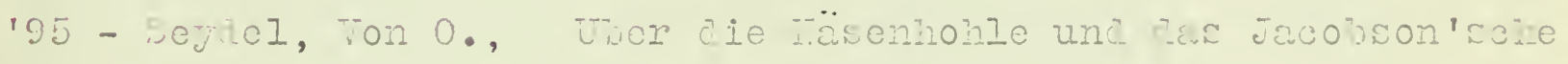

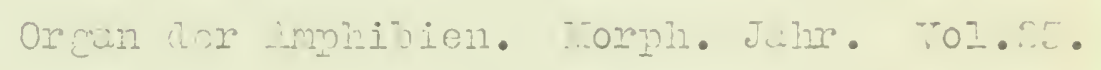

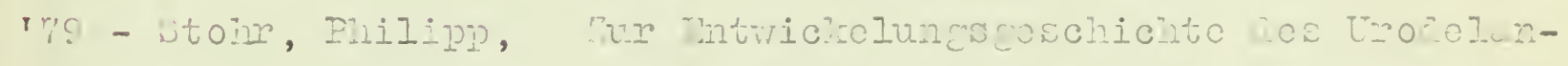

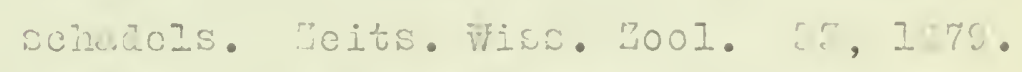

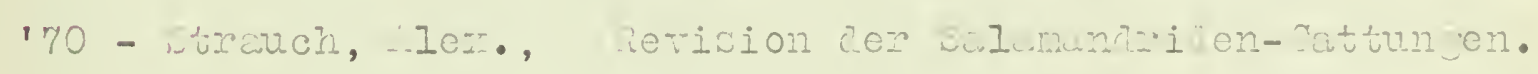

Iomoires de I'ncul. Inp. weicnons re ti.

2oterabure. Vol. 10, $15 \% 0$.

$100-\operatorname{Topry}$, ‥

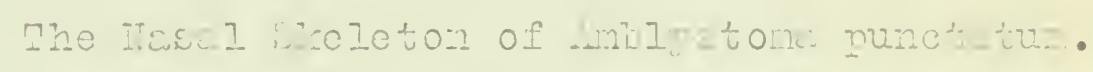
Ircins. of ine icud. Of wicnce of it. Iouris. TOI. I6, 1200 .

ryp - Wiocershein, R., Dis ropfsrelot dor Uro Uelen. arph o jahro. III, $18 \%$.

ro -
reI - mizaei, …,

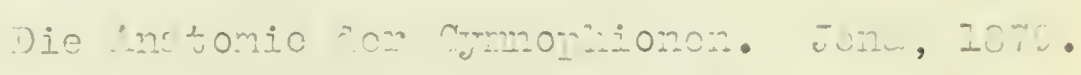
$\therefore$ rontrilution to the matom of iton

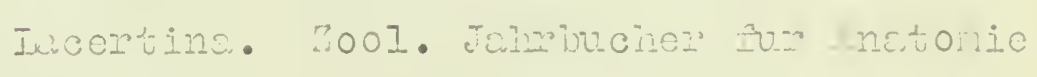
unc ontogonic. Time Ir, Isol. 

$192-$ inIdeI, ….

Jie Insengeson? ton zenopona alle phiniense

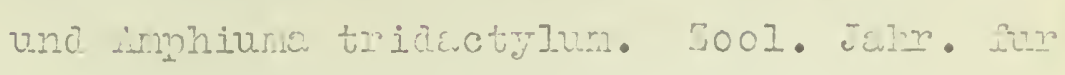
angt. und ontos. उend $T \cdot 1802$.

roz -

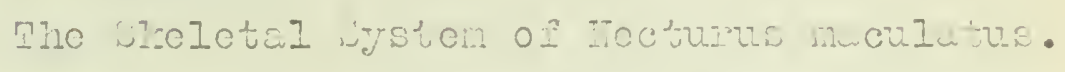

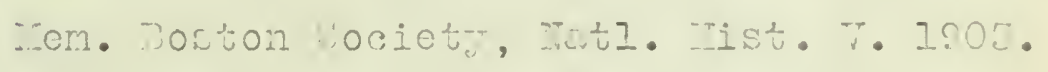

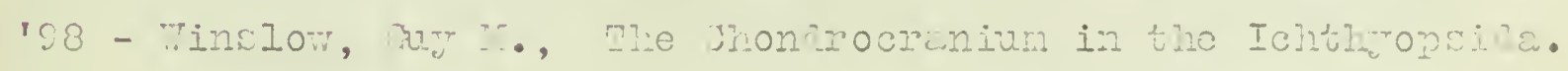

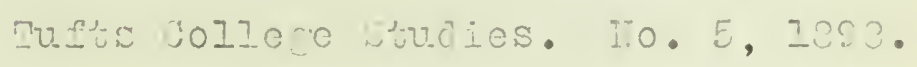

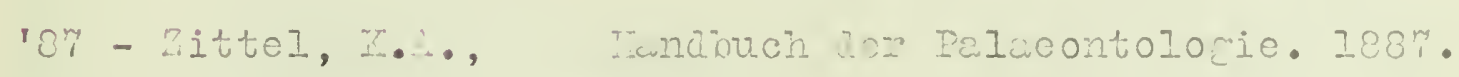





\section{1}

Dbretictions Used.

i.I. P., culcur ñocess.

c.m.p., cuntorior nanillang procoss.

w.in.c., ilincsel cantilcêe.

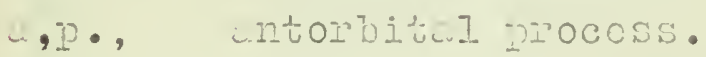

c., culn.

c.c., cuturn cranii.

c.e., columin etizoincis.

co.n, comhlic nocons.

ch., chonna.

c.i., civun innorius.

c.m., c.mun modium.

c.j., cauten procoss.

c.r., circumncuicu ring.

cr.e., criste subncus Iis.

cr.t., cisida trabucula.

c.s., cetrin sujorius.

c.t., corru trabecul.

C.P., GOME I nOOCOS.

e. ethmojic bone.

e.0., etmoinc bricice.

o.n., ozuconsin nemis.

c.n.c., oatomal naxal gune.

fon. oth., fenostr. othroid lis.

Ien.i.c., " infun-conchalia.

fon.n., " $\quad \min i n$.

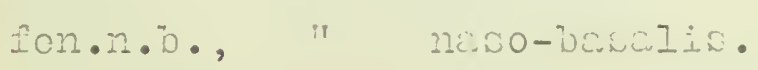

sen. Dr. fenertratou DIOCess. 

f.il.c., jopmen nusulis ozernus.

i.n.i., foranon nescuis intornus.

-.o., formen olfictorius.

f.o.n., forenen onbito-nacelis.

In., fronteriz lone.

f.r.i., forwen mos montilis.

L.s., monter bronch ol sumpicicis.

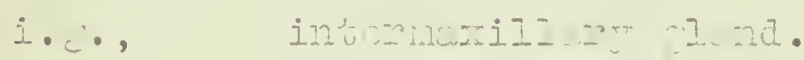

i.n.c.

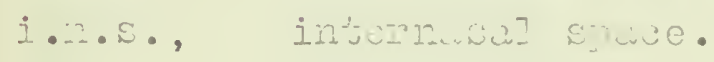

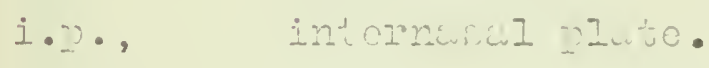

i.p.e., infoior prone. c c rtizue.

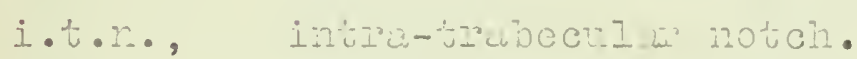

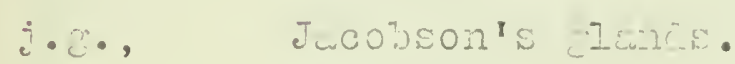

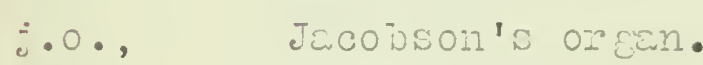

I.c., 2.nini cribose.

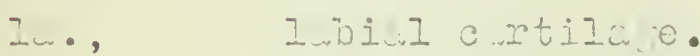

I.č., Izcoimi enct.

m., manilany pone.

m.n.i., nocinn nusul incisune.

n.21.2., medion nisul mocess.

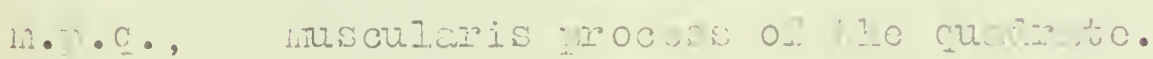

n., ne. I bone.

n. O., nast oncon.

o.c., ojlique c.rtil. o.

0.1., Olnctom Iobc.

o.n., olnctom nome.

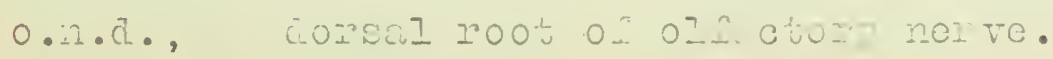





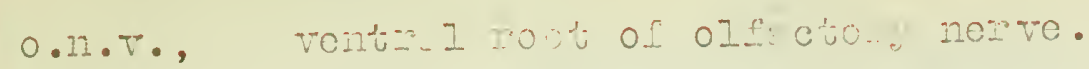

o.o., ontic orcen.

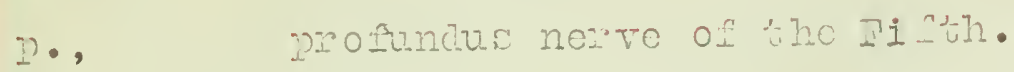

p.e., manum etrioiculis.

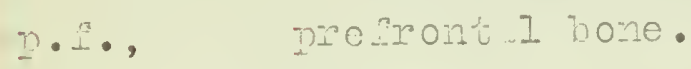

i.m., $\quad$ grom anilary ono.

p.n.p. wencon puocos.

2.0.3., neconitil idenc.

2. 2.

p.pi., Dens picine.

is., purominenoid.

p.t., planum tezininele.

I. , quacione.

a.e., ducodiato-etimointis procosi.

I., IOStrom.

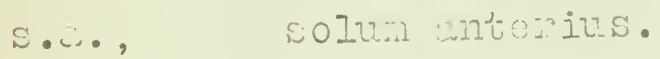

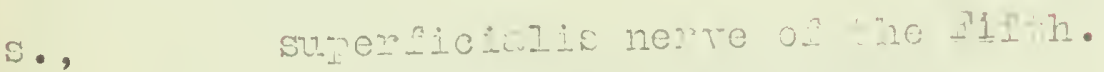

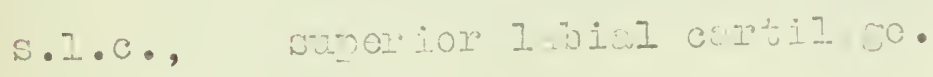

s.in., sonturn nisi.

no.n., solum nscicie.

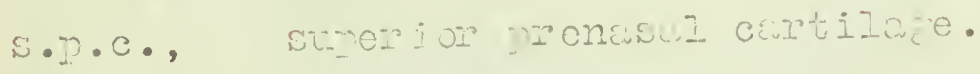

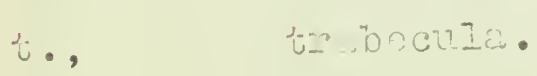

t.c., troberir o:tonsion.

i..., tectin nesale.

t.r., trubecun I

V., Tronor.

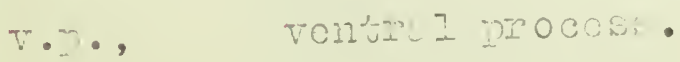





\section{1}

ixplanation o: Platos.

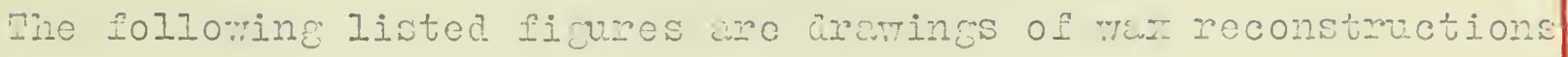

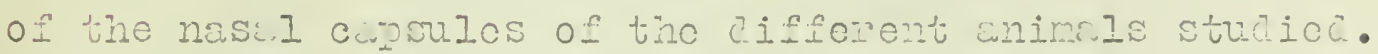

-18. I - imbIystoma Junctatum; $11 \mathrm{~mm}$ Ione, dorsc I wien.

\begin{tabular}{|c|c|c|c|c|c|c|c|c|c|c|}
\hline$\hat{z}$ & -- & $n$ & $" 1$ & ; 10 & $n$ & 17, & $" 1$ & & $n$ & • \\
\hline 5 & -- & $"$ & $n$ & $; 85$ & $"$ & , & $"$ & & $"$ & - \\
\hline 4 & -- & $"$ & $"$ & ; 25 & $" 1$ & , s & sico & rien & & • \\
\hline 5 & -- & $" 1$ & "I & ; 54 & $" 1$ & "I, & Orse: & $1 T i$ & ic $\cdots$ & $\therefore$ \\
\hline & -- & $"$ & $"$ & 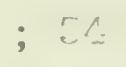 & i) $\quad n$ & $"$, T & rentra & $a 1$ & $"$. & $\bullet$ \\
\hline 7 & - & $"$ & $n$ & $; 45$ & $" 1$ & $", d$ & 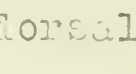 & 1 & $" 1$ & • \\
\hline 8 & -- & $\pi$ & 11 & $; \leq 5$ & " & $"$, & ronetra & 1 & $"$ & - \\
\hline 2 & -- & is & " & ; 55 & ir & $"$, & $\log ^{2}=2$ & 2 & 18 & - \\
\hline 10 & -- & $"$ & $" 1$ & ; at & tzo en & $n: 0:$ & moten? & ? & 2isos & is. \\
\hline 11 & -- & wa.1amend:-2 necu & U.zetci & $; 25$ & $\mathrm{~mm} \cdot 10$ & one, c & $20 \cos 2$ & & i CTा. & . \\
\hline 12 & -- & $"$ & $" 1$ & ; 58 & " & $"$, & $"$ & & $n$ & - \\
\hline 10 & -- & $n$ & $" 1$ & $; 2 \downarrow$ & inle cn & ac. of & notsi & norp & ison & is. \\
\hline $1 \leq$ & -- & Jienictylũ vi & riuesce & on: & $58 \mathrm{~mm}$ & - 1012? & , $\quad 10=$ & :SEI & & icw. \\
\hline 15 & -- & $" 1$ & $n$ & ; & celult & stace, & 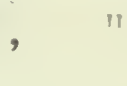 & & & - \\
\hline 16 & -- & I工iton czistatu & v.s; 28 & $\operatorname{lin} 2$ & $1012 \check{c}$ & EOID: & 1 i ic & 列 & & \\
\hline 17 & -- & " & ; 35 & F & " , & " & "1 & $\cdot$ & & \\
\hline 20 & -- & woleipes uiliz & ncatzo & ; 13 & $\operatorname{mon} \cdot 10$ & birc, & $O=N E Z$ & $V i$ & ent & $\bullet$ \\
\hline 10 & -- & $"$ & $"$ & $; 37$ & $" 1$ & $"$, & $"$ & 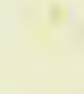 & $n$. & - \\
\hline 20 & -- & $n$ & $" 1$ & $; \leq E$ & $"$ & $"$ & $" 1$ & & $"$ & - \\
\hline 21 & -- & $"$ & I: & $; 1 \leq 0$ & $: 1$ & $"$, & „itco & vic & $\pi$ & - \\
\hline $2 n$ & -- & Jruptorancius & $\operatorname{col} 100$ & heinio & onsis; & 七wo : & recis & 018 &,$\therefore i$ & \\
\hline 23 & -- & $\pi$ & & $" 1$ & ; trgo w & montils & old & 20 & & I vicr. \\
\hline 24 & -- & $"$ & & $"$; & ; timec & e $"$ & $"$, & rent & & 1 inew. \\
\hline
\end{tabular}



is. 25 -- Tecturus meculatus; $25 \mathrm{~mm}$. Ione, dorsal viow.

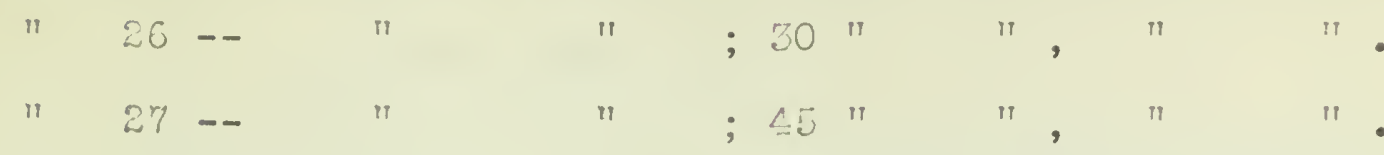

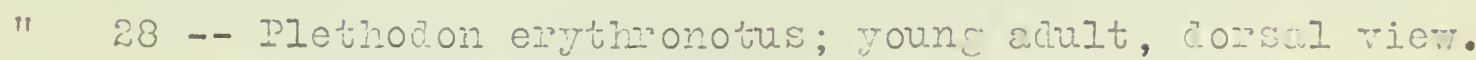

$" 29$-- muruma neans; youngor larva, dorsal viow

" 50 - " ; OIder " "rentral "

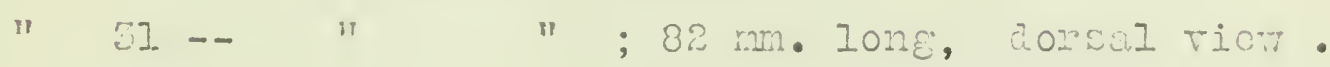

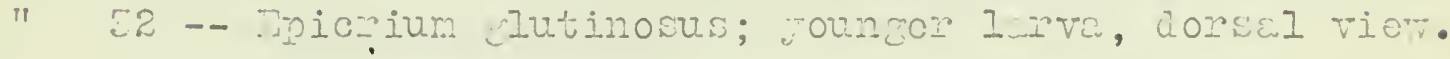

" एँ " " $" 90 \mathrm{~mm}$. Ionह, "

" 5s -- Pipa cmericana; corscui vier.

"5-" " $"$ " ronstal vion.

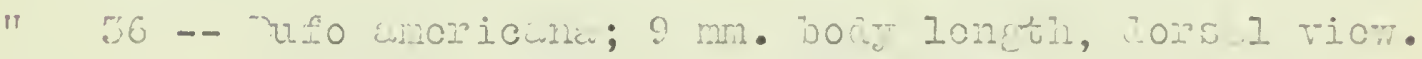

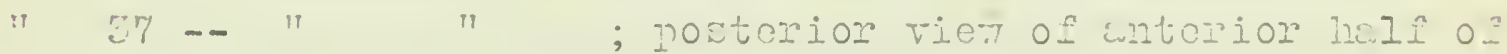
censule.

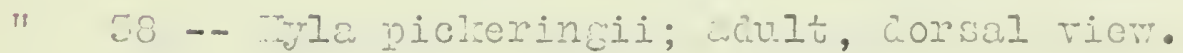

50 - 11 " $"$ " sinc rion.

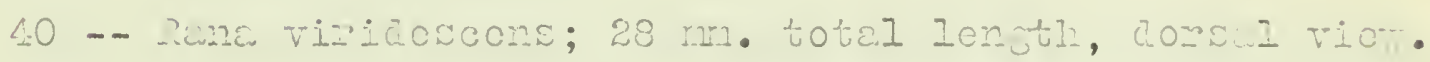

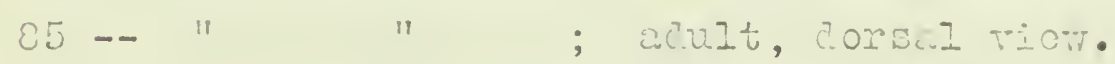

86 -. " $"$ " sice rict.

The following listod fivies aro muming on wections in tro othnoidal recion of the aiffonent anin lo studich.

rig. LI - Wection throu in the anterior part of the nas l orm of mblystome punctitum, $13 \mathrm{~mm}$. Ions.

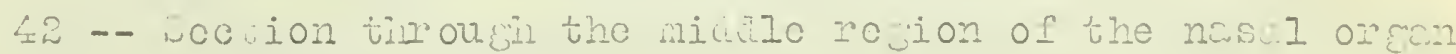
of the sane unimi. 



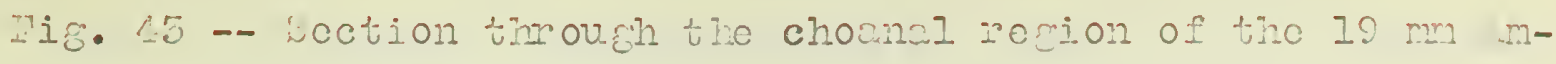
blostone punctatum.

" LA -- Section tingough tiro antorior nart of tho $25 \mathrm{~mm}$. AnDItstoma punctatun.

$" 45$ - Dection just entorior to tho sortur nasi of tho 55h.. -niolystoni punctatur.

$"$ Le - Lection shouch tho soptum nasi of the $55 \mathrm{~mm}$. Anbigntome punctatum.

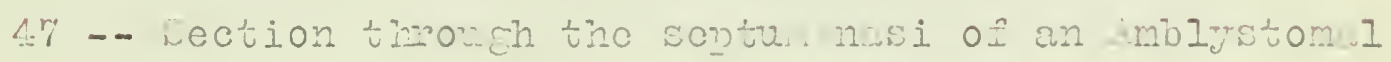
larve at the end of motarnorpiosis.

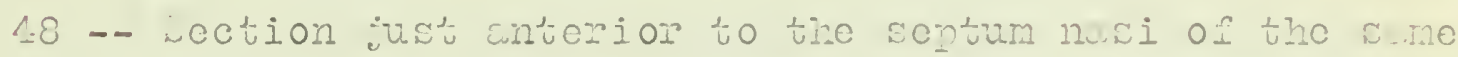
cunimal, through tho ionestur infer-conchelis.

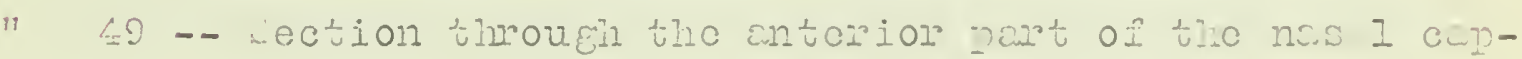
sule of balamancies maculata, $25 \mathrm{~mm}$. 1one

50 -- iection throu the choancl pocion of a $25 \mathrm{~mm}$. Winlumancira moculata.

" 51 -- wection though the sontum nosi of t. $38 \mathrm{mn}$. Walcuranura maculata; passing through tho fonestra ethrnoiluli

" 52 -- vection trrough the postorior rocion of tie nawa capsule of alamanira naculata, wot tho enl of motamorphosis.

" 53 - - Section ju.st cuntorior to tho othmoid pleto of Dienictylus viriacscens, $58 \mathrm{~mm}$. Ione.

"5\% -. Soction trrough the anterior region of tho nasal capsules of Jicnictulus viridoscens, $38 \mathrm{~mm}$. Ione

" 55 - - wection justu antorior to t’o planum otrmoicalis of the suiult Jionictylus viridoscens. 



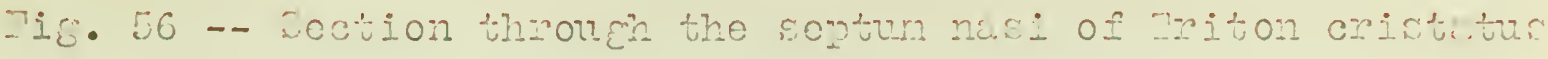
28 mons.

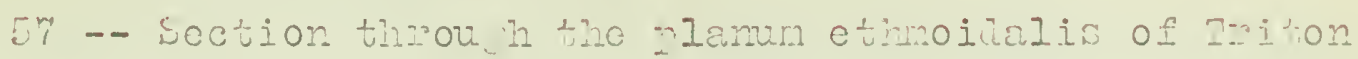
crictatus, $55 \mathrm{~mm}$. $10 n g$.

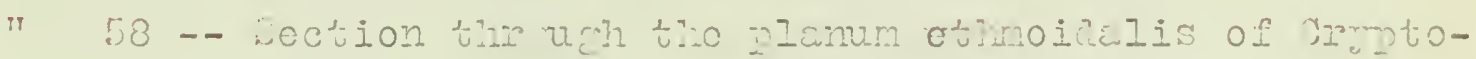
orenchus cllogheniensis, two nonths old.

50 -- ioction throu tho cuterion oni of nnelermes bilinortus, IE m. lon

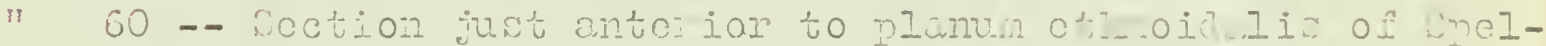
orpos bizincatus, $57 \mathrm{~mm}$. Ions.

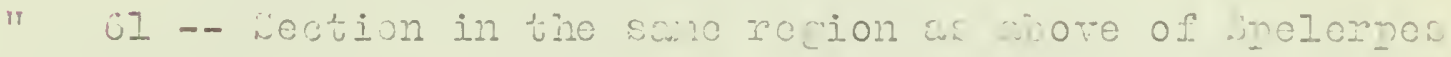

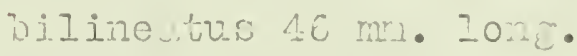

" 62 -- Section throuch tre cliownI mocion of Pletro?on oregtirisonotus.

$" 65$-- Section just unterior to tho plimm etholn Iia of Eletrodon clyounonotris.

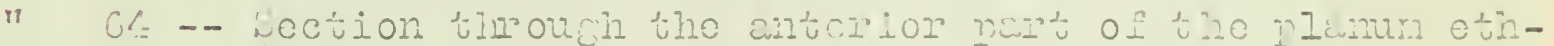

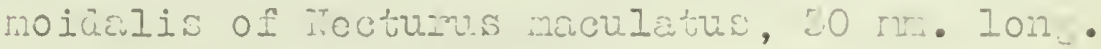

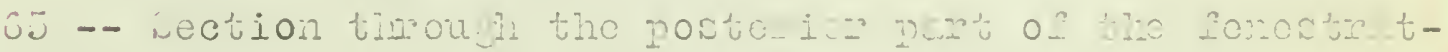

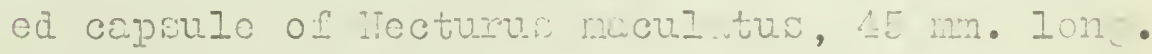

" 66 -- Section through the nas ? goptun of youncer micrium $n$ $67-$

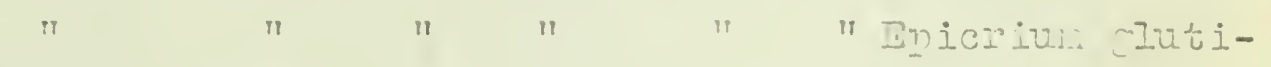
nosus, 20 H. IOn:

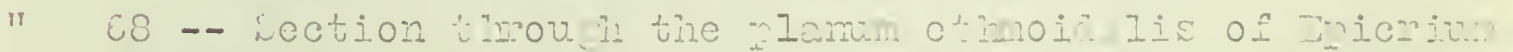
Iutinosus, so mone. Ion

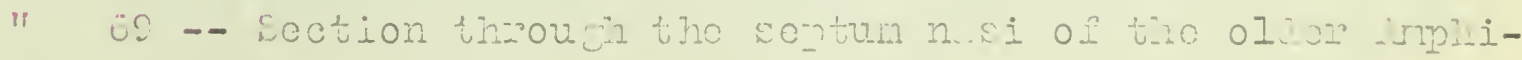
uns neans 



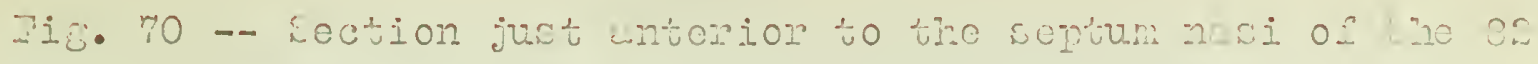
ma. imphivina noens.

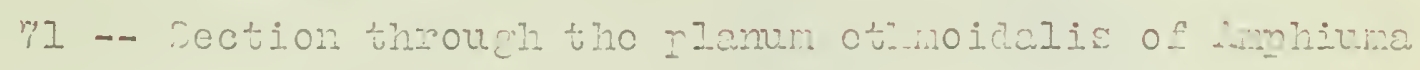
mechs $3: m$. Ione

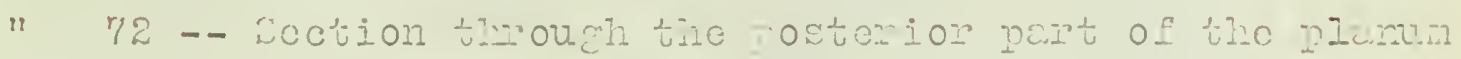

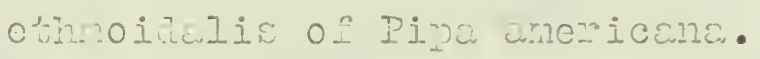

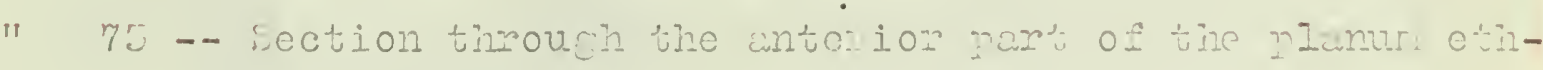
moiculis of pioa moricuna.

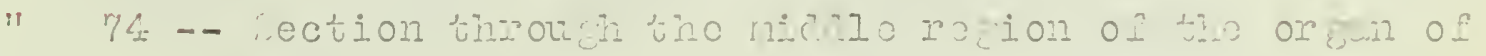
Jacobron of Pip (E. oricina.

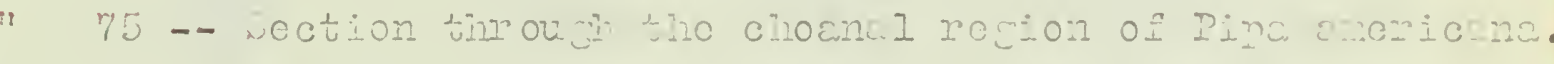

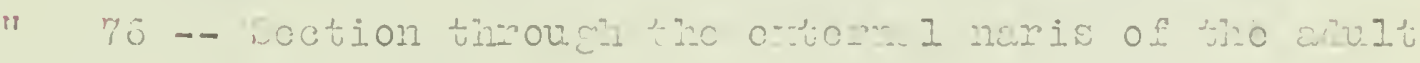
-Tla piciocincio.

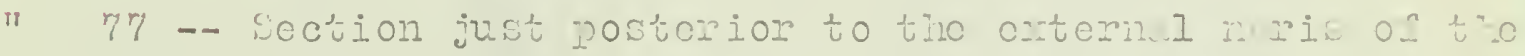
ecult Tyla piclecincii.

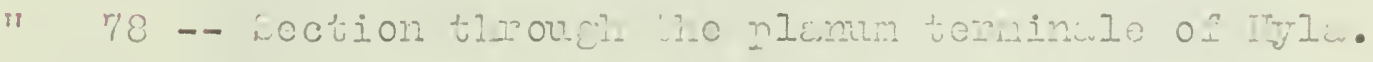

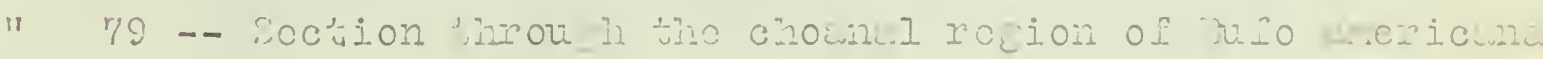
$9 \mathrm{~mm}$. Iong, boiry longth.

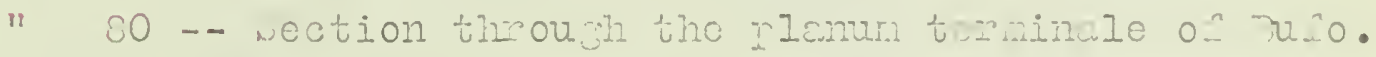

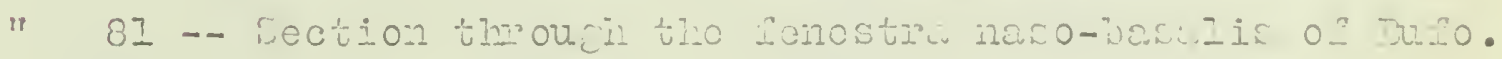

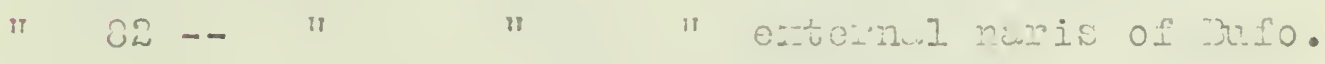

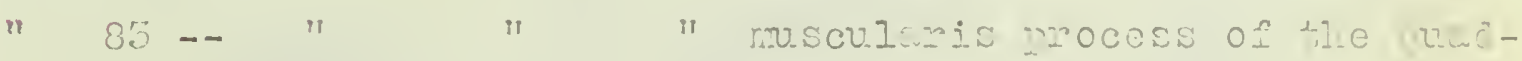
rutc of R: na viridescons, $28 \mathrm{~m}$. Ion

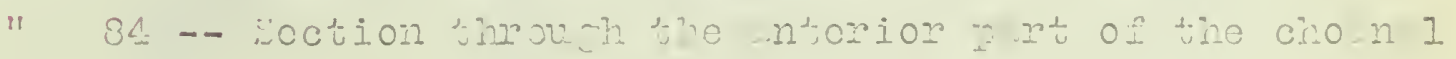

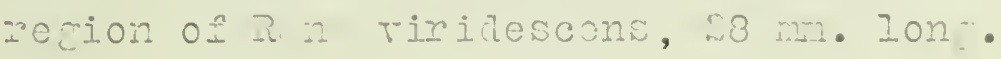



PLATE I
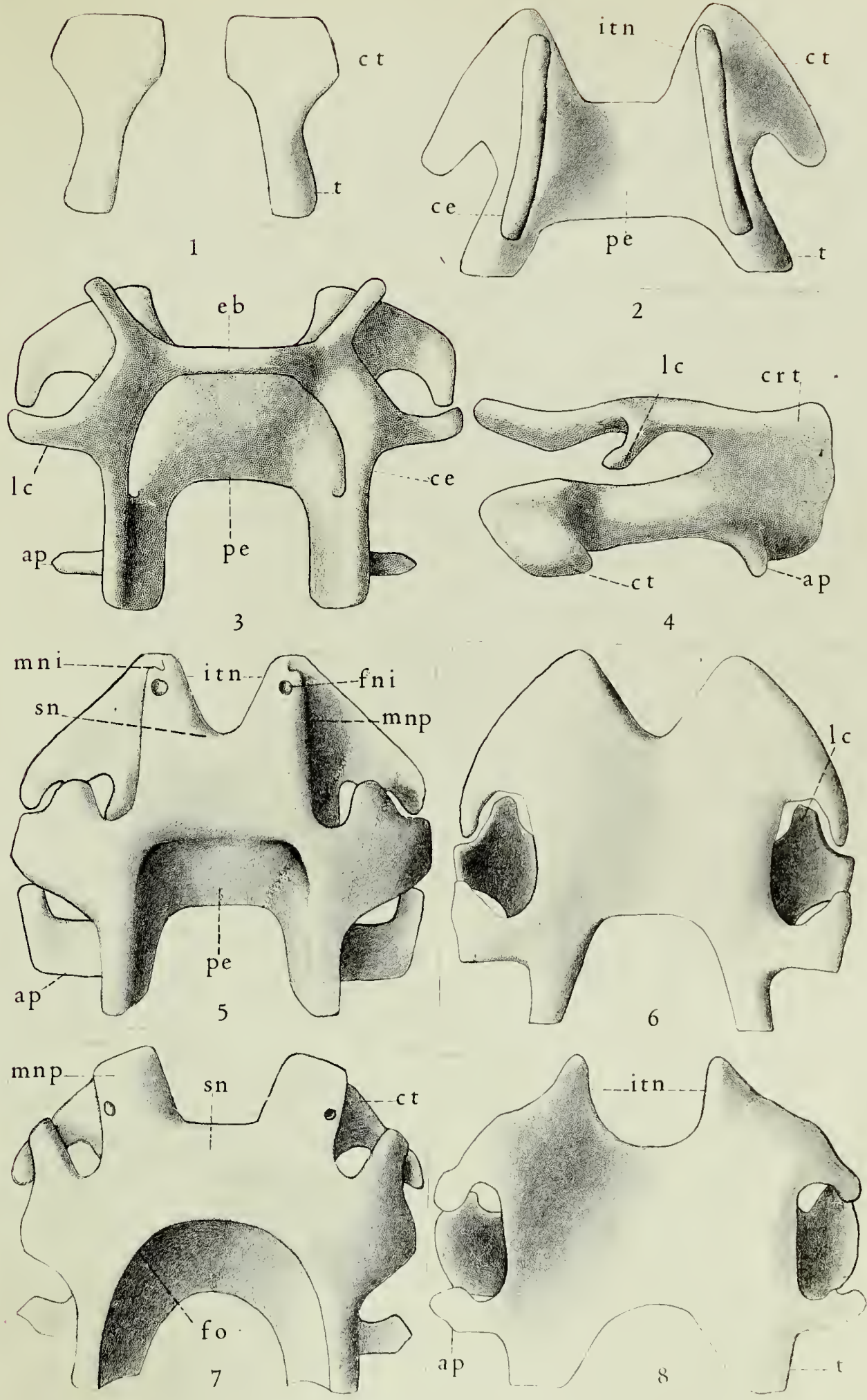
THE LIEGaRYY

OF THE

UNIVERSITY OF ILLINOIS 


\section{PLATE II}
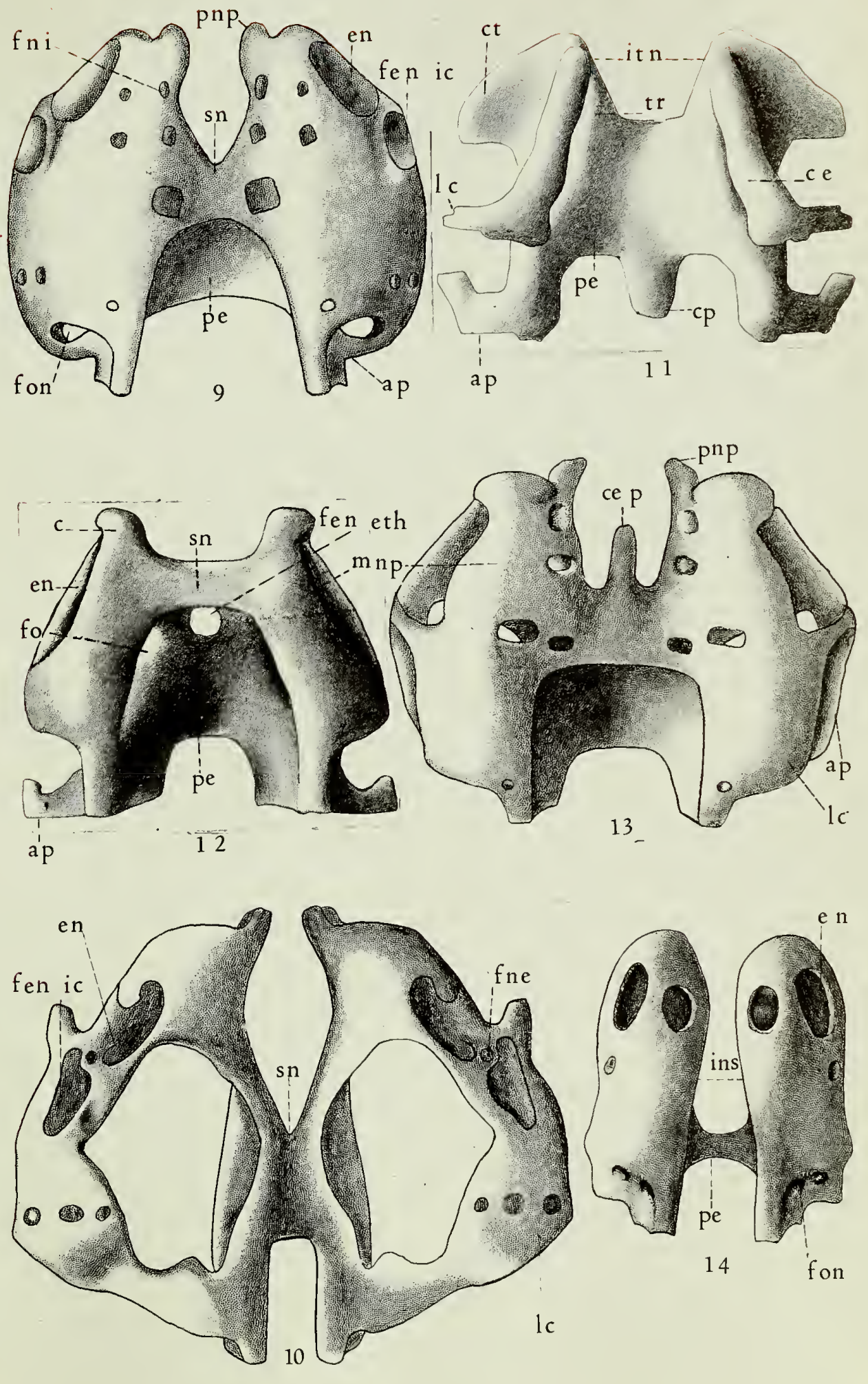

PLATE III
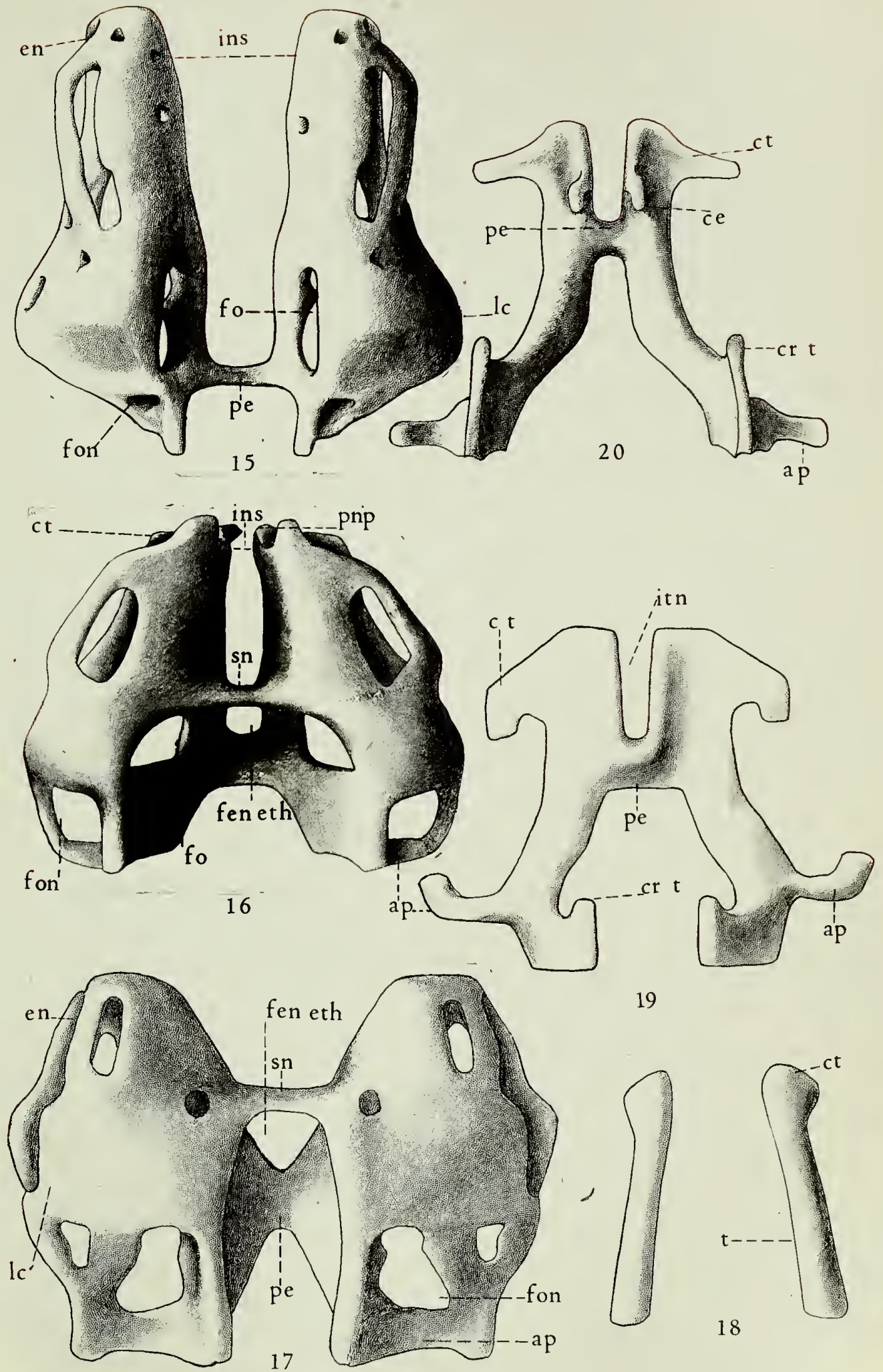

19

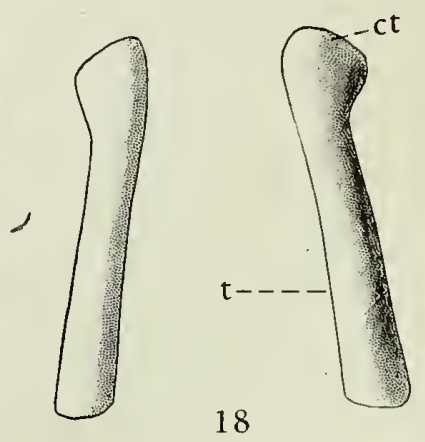


The Limpin

OF THE

UNIVERSITY OF ILLINOIS 


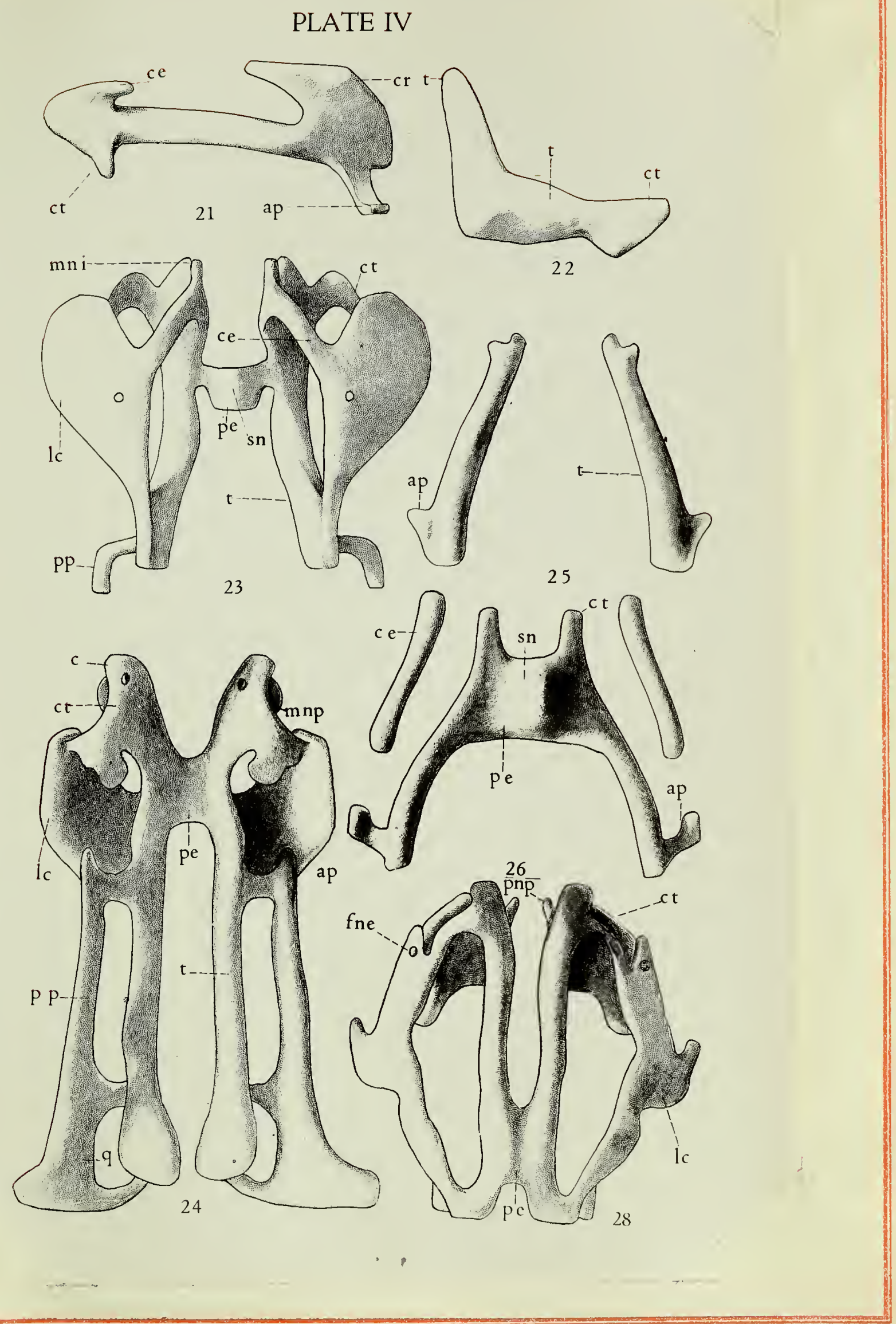


TTE LIBRARY

OF THE

UIIVERSITY OF ILLINOIS 
PITH V
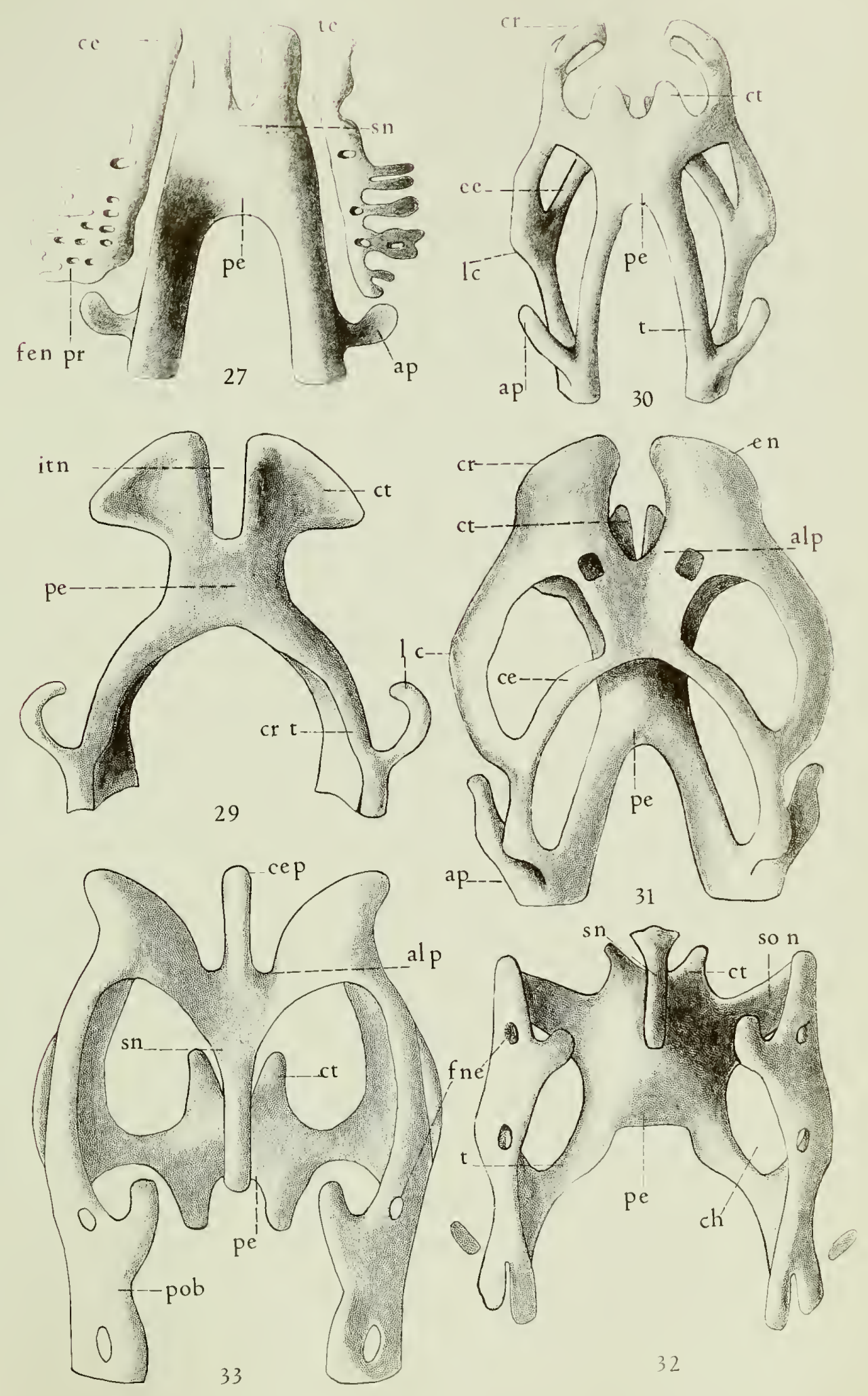



\section{PLATE VI}
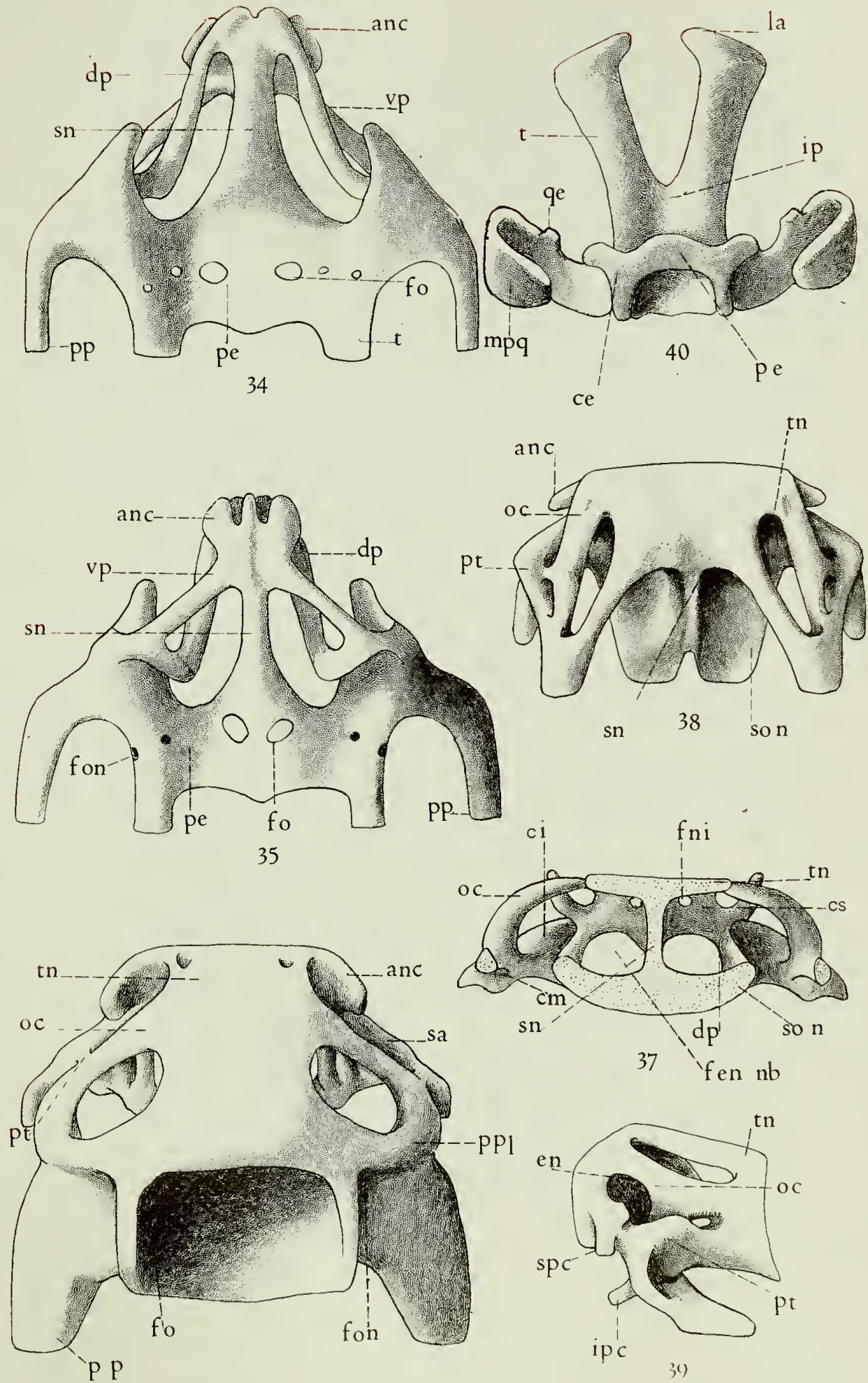

ipc 
THE LIEGARTY

OF THE

UNIVERSIIY OF ILLINOIS 


\section{PLATE VII}
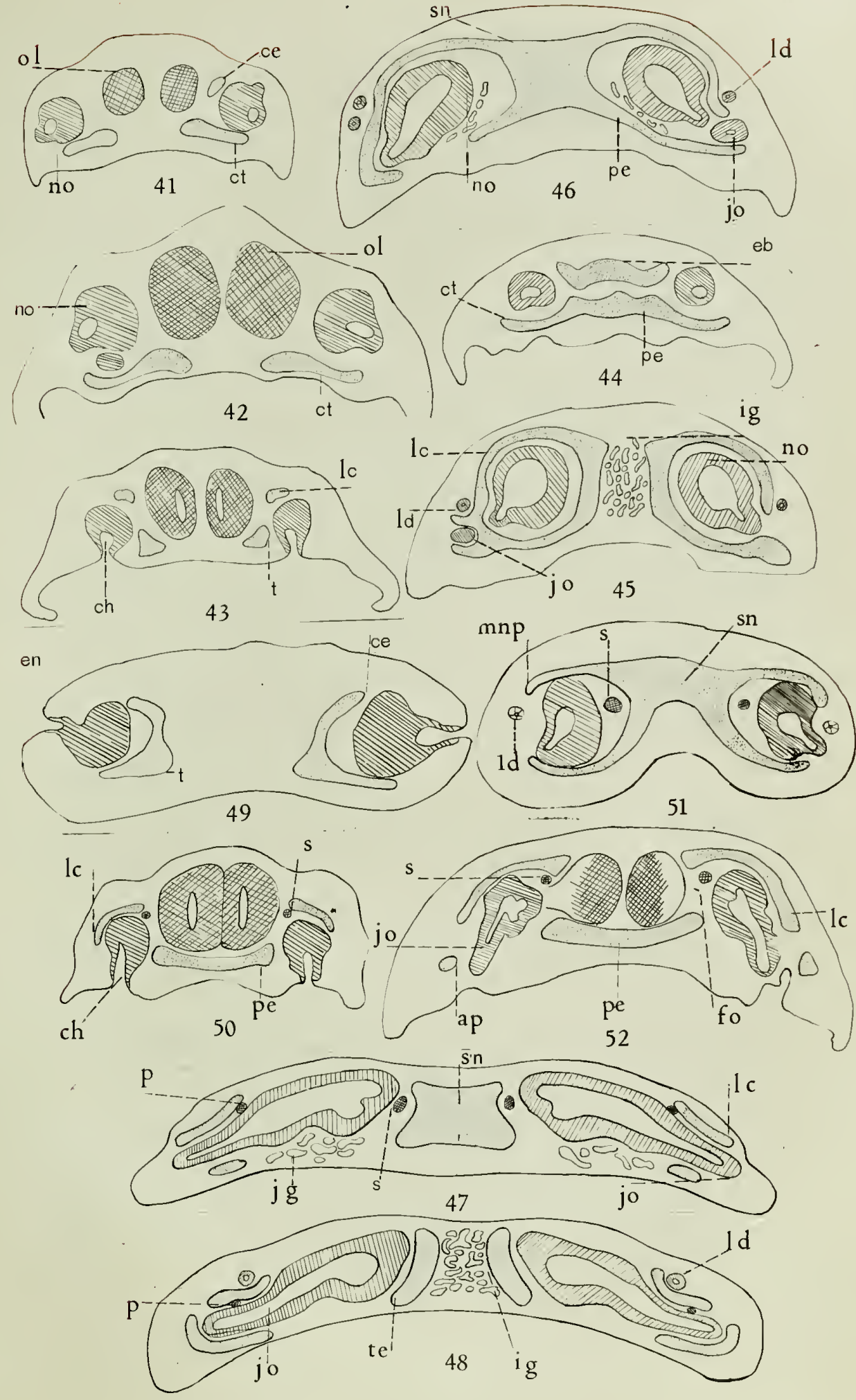



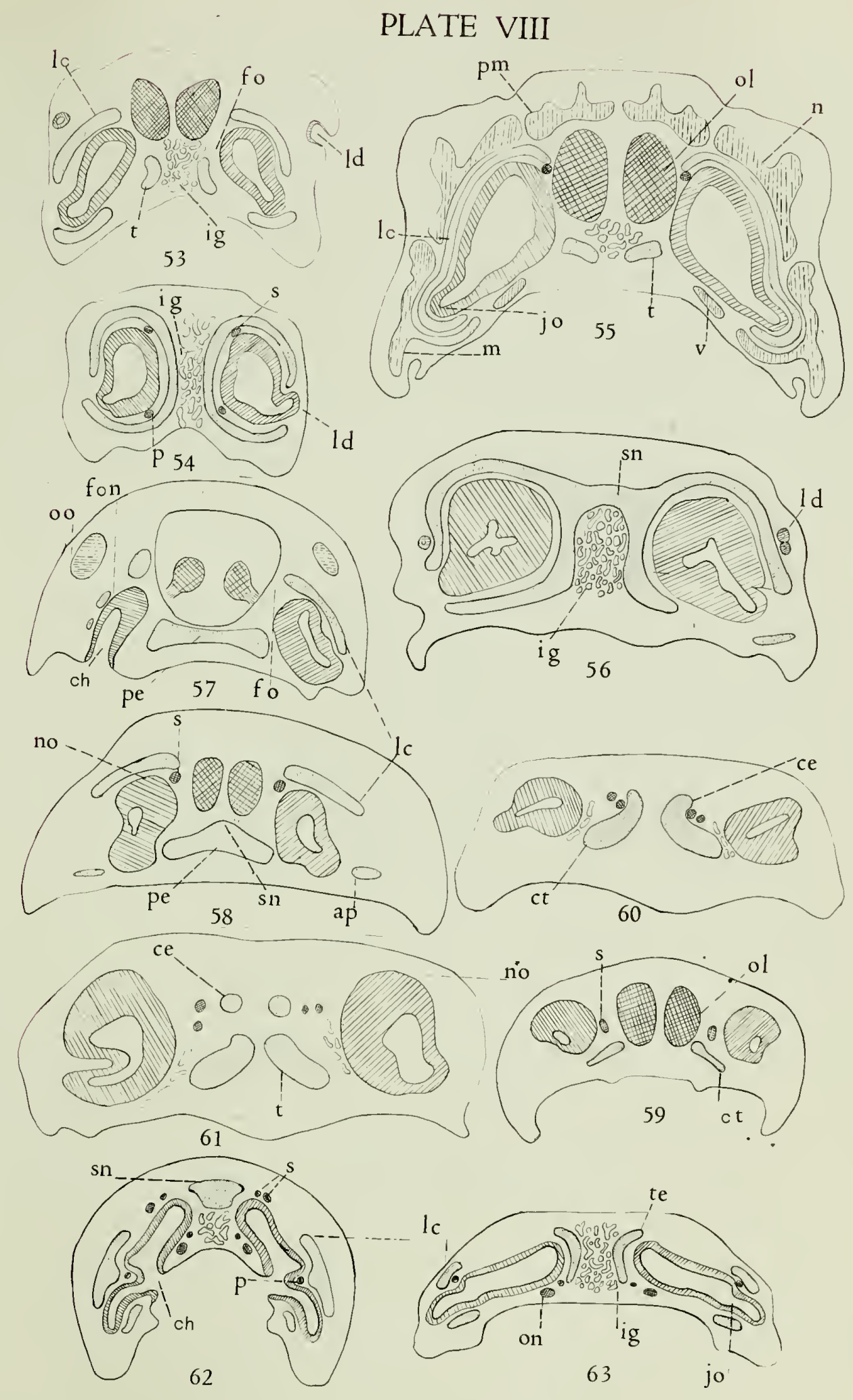





\section{PLATE IX}

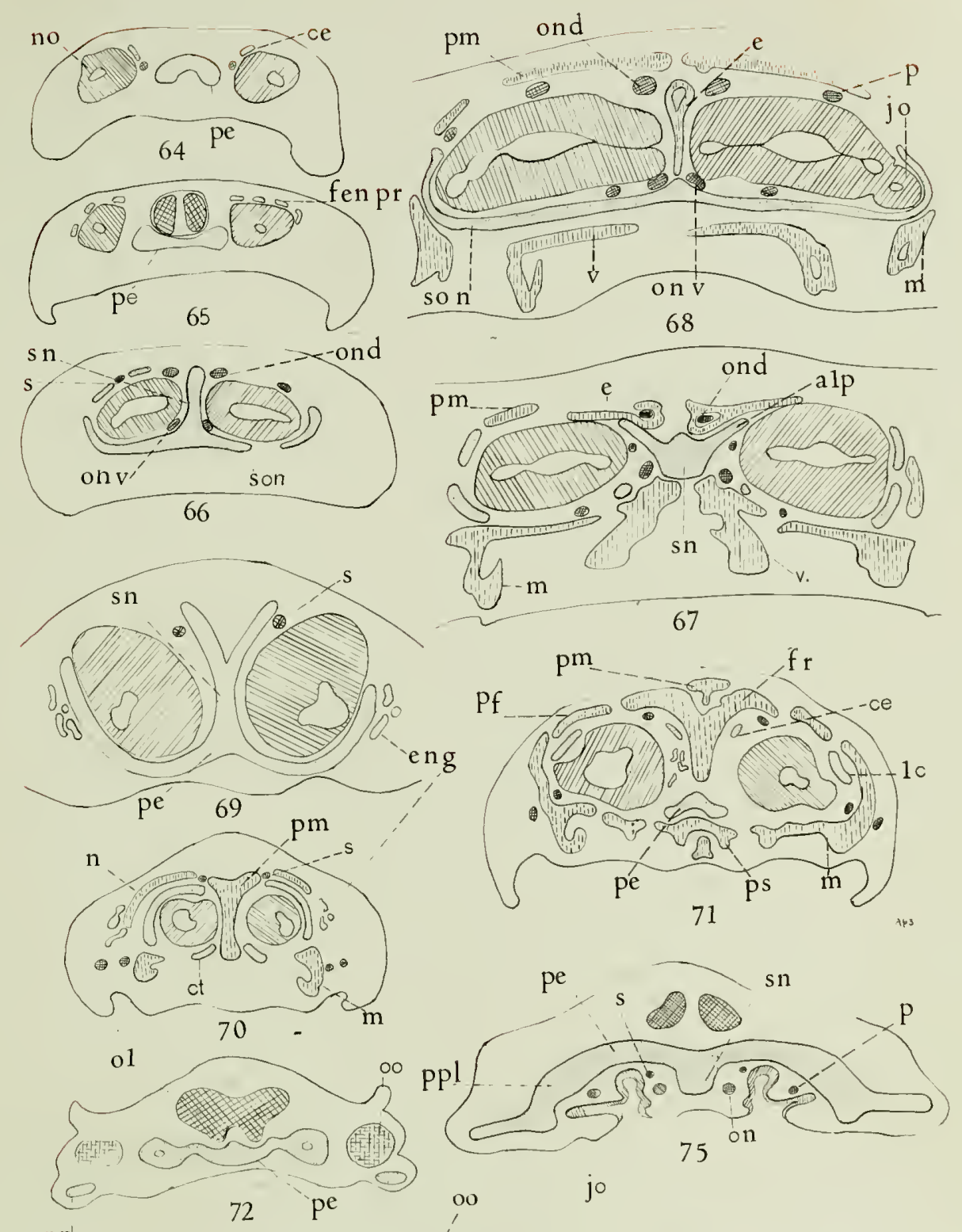

$\mathrm{pp}$ 
THE LIBHARY

OF IHE

UYIVERSITY DF ILLINOIS 


\section{PLATE $X$}
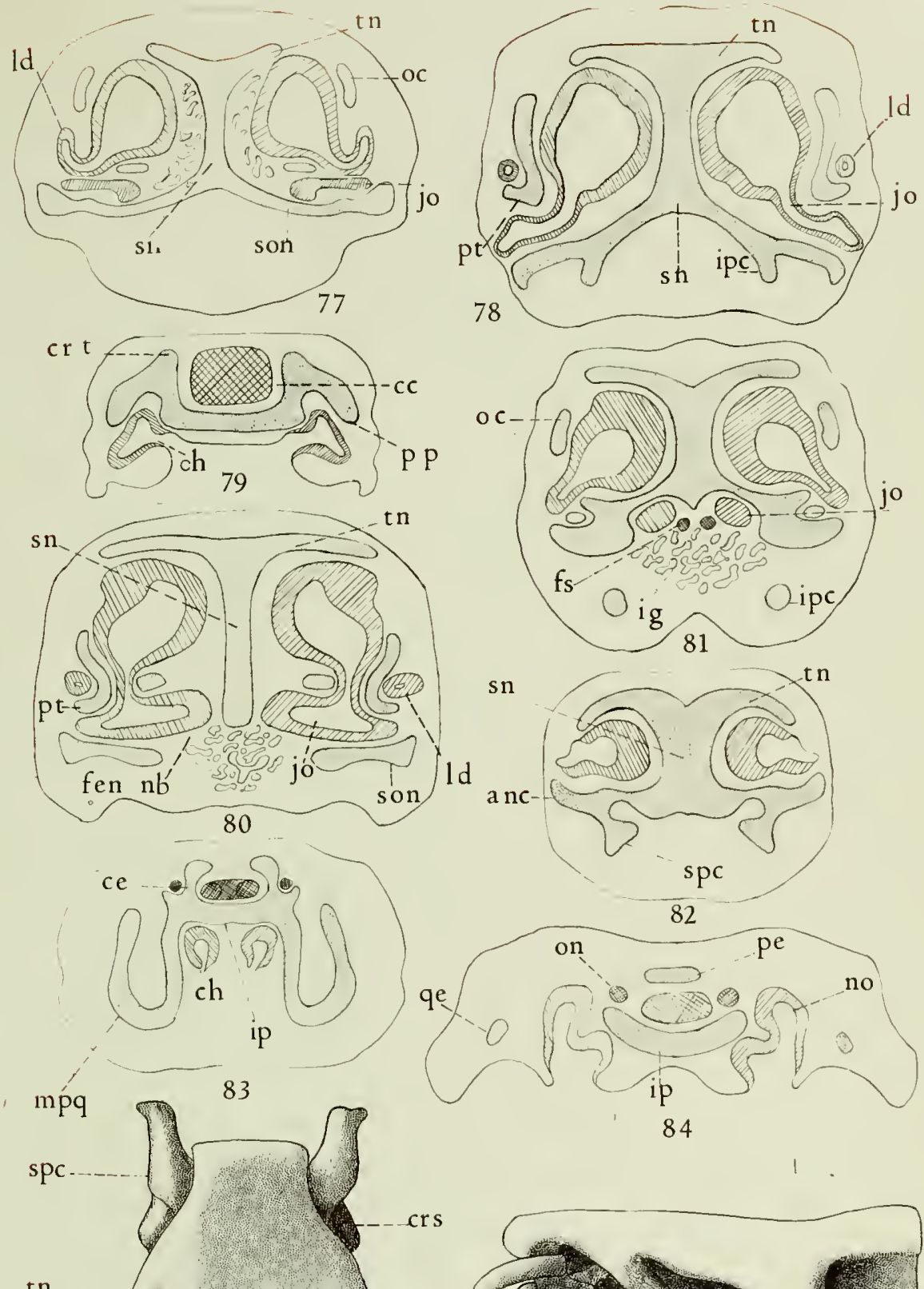

tn
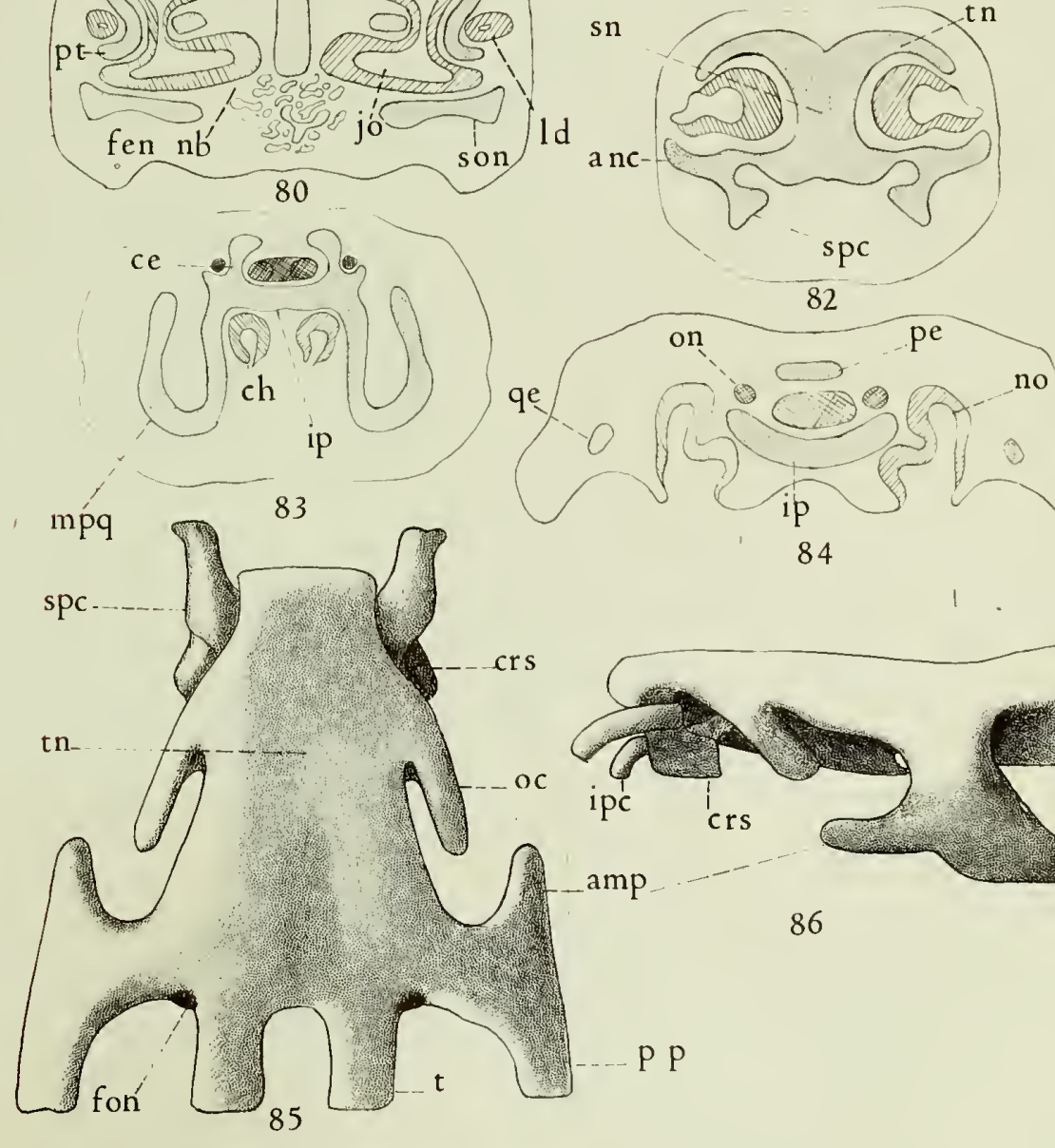
SIOHIרา JO RAISHJAINA

उसI 50

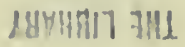




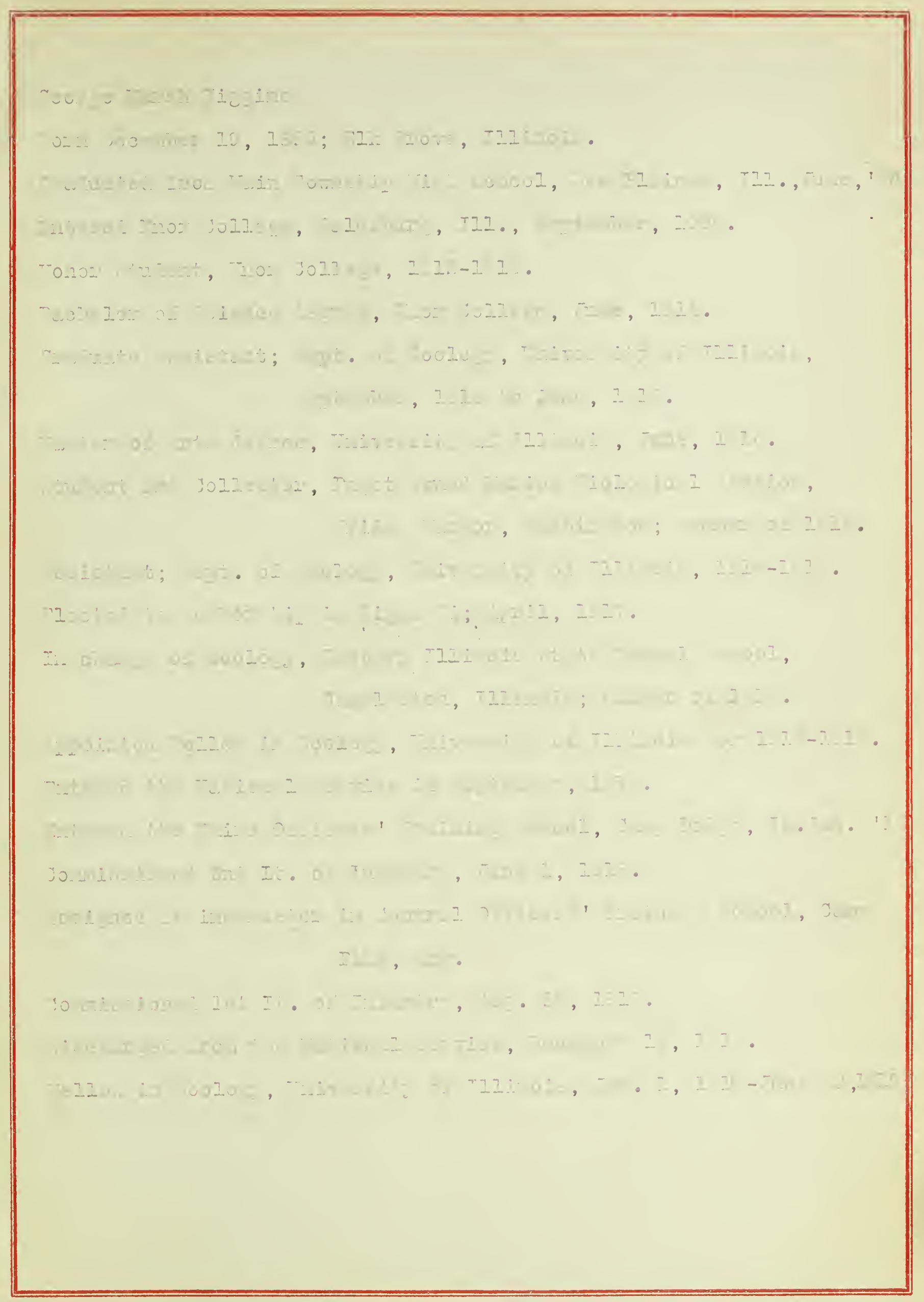




